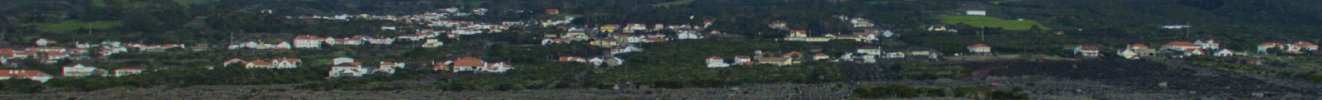
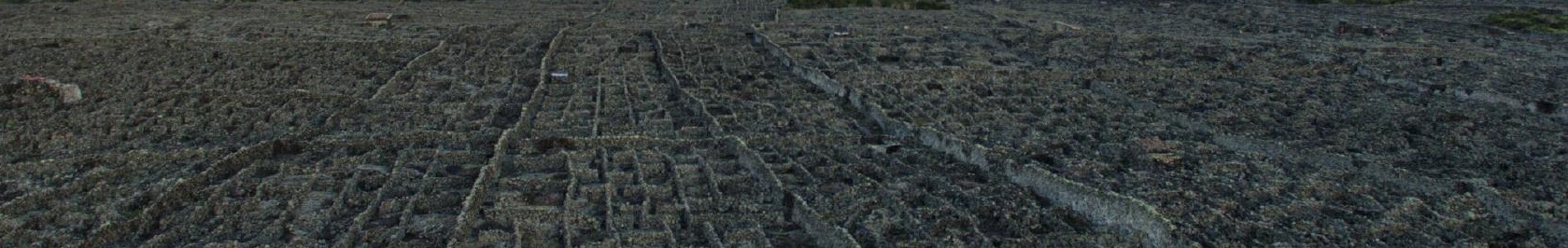

\title{
PAISAGEM DA CULTURA DA \\ VINHA DA ILHA DO PICO \\ (QUINZE ANOS PATRIMÓNIO \\ MUNDIAL DA UNESCO) \\ III WORKSHOP DOURO E PICO 2019
}

COORD.

MARIA OTÍLIA PEREIRA LAGE

MANUEL PAULINO DA COSTA

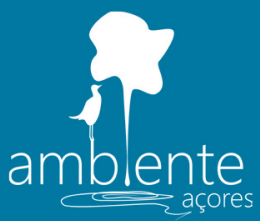




\section{PAISAGEM DA CULTURA DA VINHA DA ILHA DO PICO (QUINZE ANOS PATRIMÓNIO MUNDIAL DA UNESCO) III WORKSHOP DOURO E PICO 2019}

COORD.

MARIA OTÍLIA PEREIRA LAGE

MANUEL PAULINO DA COSTA

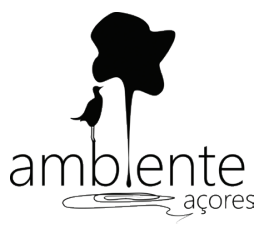


Título: Paisagem da Cultura da Vinha da Ilha do Pico (Quinze Anos Património Mundial da UNESCO). III Workshop Douro e Pico 2019

Coordenação: Maria Otília Pereira Lage, Manuel Paulino da Costa

Design gráfico: Helena Lobo Design | www.hldesign.pt

Imagem da capa: Paisagem da Cultura da Vinha da Ilha do Pico. Foto de José Feliciano

Coedição: CITCEM - Centro de Investigação Transdisciplinar Cultura, Espaço e Memória

Via Panorâmica, s/n | 4150-564 Porto | www.citcem.org | citcem@letras.up.pt

Direção Regional do Ambiente e Alterações Climáticas

Rua Cônsul Dabney, Colónia Alemã, Apartado 140 | 9900-014 HORTA

info.draac@azores.gov.pt | https://portal.azores.gov.pt/web/draac

Depósito legal: 484753/21

ISBN: 978-989-8970-28-2

DOI: https://doi.org/10.21747/9789898970282/pais

Porto, junho de 2021

Paginação, impressão e acabamento: Sersilito-Empresa Gráfica, Lda. | www.sersilito.pt

Este trabalho é financiado por Fundos Nacionais através da FCT - Fundação para a Ciência e a Tecnologia, no âmbito do projeto UIDB/04059/2020. 


\section{SUMÁRIO}

APRESENTAÇÃO

Maria Otília Pereira Lage, Manuel Paulino da Costa

I. COMEMORAÇÃO DAS CLASSIFICAÇÕES: PAISAGEM PROTEGIDA E PATRIMÓNIO MUNDIAL 9

1. Semana cultural comemorativa da efeméride 11

2. Realizações, relevância, adesão e impacto dos eventos 15

II. PAISAGENS CULTURAIS VINHATEIRAS, PATRIMÓNIO DA HUMANIDADE (III WORKSHOP DOURO E PICO)

1. PAISAGEM DA CULTURA DA VINHA DA ILHA DO PICO PATRIMÓNIO MUNDIAL: QUINZE ANOS DE CLASSIFICAÇÃO

Paisagem da Cultura da Vinha da Ilha do Pico - Prémio Nacional da Paisagem 2018

Hernâni Jorge

\section{ENTIDADES DE GESTÃO DOS PATRIMÓNIOS MUNDIAIS PICO E ADV}

Paisagem da Cultura da Vinha da Ilha do Pico: Potencialidades e Enlaces (parcerias, turismo de qualidade, educação inclusiva de comunidades)

Manuel Paulino da Costa

Pico e Douro - Patrimónios da Humanidade: Potencialidades e Enlaces (parcerias, turismo de qualidade, educação inclusiva de comunidades)

Helena Teles

3. POPULAÇÕES DA ILHA DO PICO E DO DOURO: HISTÓRIA E DEMOGRAFIA HISTÓRICA 
5. VALORIZAÇÃO E SUSTENTABILIDADE DO PATRIMÓNIO VITIVINÍCOLA HISTÓRICO-CULTURAL DOS TERRITÓRIOS DO PICO E DO DOURO

Museus do Pico

Manuel Francisco Costa Jr.

O Museu do Douro: Perspetivas de um Museu de território

Natália Fauvrelle 


\title{
APRESENTAÇÃO
}

\author{
MARIA OTÍLIA PEREIRA LAGE* \\ MANUEL PAULINO DA COSTA**
}

Por constituir uma excelente representação da arquitetura tradicional ligada à cultura da vinha, do desenho da paisagem e dos elementos naturais, a Paisagem da Cultura da Vinha da Ilha do Pico foi classificada como área protegida a 27 de junho de 1996 e, a 2 de julho de 2004, foi aprovada pela UNESCO como Património Mundial. O programa comemorativo dos 23 anos da Paisagem da Cultura da Vinha da Ilha do Pico como área protegida e dos 15 anos como Património Mundial da UNESCO decorreu de 27 de junho a 2 de julho de 2019 na ilha do Pico (concelhos de Madalena e São Roque do Pico), com variadas iniciativas que evocaram a importância ambiental e cultural desta paisagem. A agenda oficial abriu em junho com os trabalhos do colóquio A Paisagem da Cultura da Vinha da ilha do Pico Contributos para o desenvolvimento sustentável e a sessão Pico de Honra - edição especial de vinhos do Lajido, tendo decorrido nos dias seguintes uma sessão solene evocativa das comemorações e diversas atividades culturais, musicais, desportivas, provas de vinhos, visitas ao Centro de Interpretação da Paisagem da Cultura da Vinha da Ilha do Pico e ao Museu do Vinho e, ainda, o lançamento e divulgação da produção multimédia Pico, ilha de oportunidades com futuro ${ }^{1}$. Encerrou a $1 \mathrm{e}$ 2 de julho, com a realização do III Workshop Douro e Pico: Paisagens Culturais Vinhateiras, Património da Humanidade, atividade conjunta do CITCEM/FLUP e da Direção Regional do Ambiente (Governo dos Açores) com o apoio de outras entidades públicas (Comissão Nacional da UNESCO, ICOMOS, FCT, Reitoria da Universidade do Porto, Museu do Douro e CCDR-N) e a presença significativa de investigadores, especialistas e público interessado de técnicos e mais elementos da sociedade civil.

Em consonância com o programa institucional sumariamente descrito, o presente livro, coedição do CITCEM e da DRA, abre com um painel de imagens

* CITCEM. Email: otilialage@sapo.pt.

** CITCEM. Email: Manuel.PS.Costa@azores.gov.pt.

${ }^{1}$ Documentário dos 15 anos da Paisagem da Cultura da Vinha da Ilha do Pico. Este vídeo, da autoria de Paulo Henriques, intitula-se Pico, ilha de oportunidades com futuro. Horta: Direção Regional do Ambiente (Governo dos Açores), 2019. Disponível em <https://www.yotube,com/watch?v=-rl g3E-UMGY>. 
ilustrativo de eventos públicos marcantes desta efeméride comemorativa e desenvolve-se na apresentação compilada de informação relevante do III Workshop Douro e Pico: Paisagens Culturais Vinhateiras, Património da Humanidade², organizado em quatro painéis temáticos: Populações, Paisagens, Museus e Patrimónios, nos quais foram apresentadas, por dez oradores convidados, nove conferências e comunicações nas óticas da história e da atualidade de correspondentes potencialidades e enlaces, valorização e desenvolvimento sustentável, debatidas em sucessivas mesas redondas.

Constitui o núcleo central desta publicação um corpus transdisciplinar de nove artigos, resultantes dos textos das conferências institucionais e dos textos das comunicações científicas, estas objeto de revisão por pares. No seu conjunto, estas contribuições configuram-se como outras tantas «versões povoadas» do Pico e do Douro: as duas paisagens culturais da vinha e do vinho Património Mundial em território português continental e insular. Abordagens técnico-científicas especializadas nas áreas da história, demografia histórica, patrimónios, museologia, território e paisagem, proporcionam aproximações complementares, em perspetiva comparada, às paisagens patrimoniais da cultura da vinha da ilha do Pico e do Alto Douro Vinhateiro, que por esta ordem se enumeram.

O ciclo de intervenções sobre a Paisagem da Cultura da Vinha da Ilha do Pico integrou as seguintes contribuições: Paisagem da Cultura da Vinha da Ilha do Pico - Prémio Nacional da Paisagem 2018, título da conferência inaugural proferida por Hernâni Jorge, diretor regional do Ambiente (Governo dos Açores), que evocou o vulcanismo e cosmopolitismo próprios de sua geologia, geografia e história singulares, definindo uma paisagem viva de grande relevância económica e social, em profunda transformação e reabilitação urbana e rural, com significativo aumento de área de vinha cultivada. Maria Norberta Amorim, professora catedrática da Universidade do Minho, especialista em demografia histórica e história das populações, apresentou neste âmbito a conferência expressivamente intitulada Espaços ardidos e o espantoso comportamento demográfico da gente que lá medrou (séculos XVII a XX). Álvaro Domingues, professor associado da Faculdade de Arquitetura da Universidade do Porto concitou também o interesse do público com a sua conferência A Paisagem, a ilha do Pico e tudo o mais. Manuel Francisco Costa Jr., diretor do Museu do Pico, apresentou a sua conferência institucional, destacando no âmbito da literatura, património e identidade cultural do Pico e dos Açores, este museu regional, relevante equipamento cultural da ilha que congrega o Museu do Vinho (Madalena), o Museu da Indústria Baleeira (S. Roque do Pico)

\footnotetext{
${ }^{2}$ Evento realizado na ilha do Pico a 1 e 2 de julho de 2019, que deu continuidade aos I e II Workshops (Porto, 2017 e 2018) no âmbito do projeto Douro e Pico: Paisagens culturais vitivinícolas históricas Património Mundial. Estudo e valorização do património histórico e cultural, CITCEM (2018-2021).
} 
e o Museu dos Baleeiros (Lajes do Pico). Maria de Jesus Maciel, investigadora do CITCEM na sua comunicação Da singularidade de uma ilha à distinção de uma paisagem destacou traços diferenciadores da história e da cultura da ilha do Pico. Manuel Paulino da Costa, diretor do Parque Natural da Ilha do Pico, salientou na sua conferência institucional a dominância abrangente do Parque Natural da Ilha do Pico, o maior dos Açores, que integra 22 áreas protegidas e reúne numa única estrutura a gestão de todas as áreas protegidas e classificadas da ilha do Pico. Nesse âmbito destacou o binómio Paisagem e Comunidade, contexto de iniciativas de sensibilização e educação sobre a paisagem e o desenvolvimento sustentável com enfoque nos programas pedagógicos Parque Aberto e Parque Escola, gerando parcerias de sustentabilidade.

Em contraponto e numa escala diferente, o território do Alto Douro Vinhateiro, Património da Humanidade, "paisagem cultural evolutiva e viva» (UNESCO) foi contemplado em algumas das suas facetas representativas, em três conferências: a primeira O Alto Douro Vinhateiro e Pico - quintas e adegas (séculos XIX-XX) de Carla Sequeira e Paula Montes Leal, investigadoras do CITCEM, sobre evolução histórica comparada; uma segunda O Museu do Douro: Perspetivas de um Museu de território de Natália Fauvrelle, coordenadora dos Serviços de Museologia do Museu do Douro e investigadora do CITCEM, abordou este equipamento cultural vocacionado para o conhecimento dos diferentes patrimónios da Região Demarcada do Douro; e, a finalizar, uma terceira conferência de natureza institucional sobre monitorização e sistema de gestão integrada do Alto Douro Vinhateiro, de Helena Teles, chefe da Estrutura Sub-regional de Vila Real/Missão Douro - Comissão de Coordenação e Desenvolvimento Regional do Norte (CCDR-N).

Por fim, desejamos que os trabalhos apresentados e debatidos em participadas mesas redondas que possibilitaram viva partilha de comentários, ideias e experiências, venham a tornar-se, com a mais ampla divulgação neste livro, um incentivo e contributo para novas investigações, estudos e trabalhos nas áreas contempladas. São devidos agradecimentos públicos a todas as instituições e entidades que patrocinaram a realização deste encontro científico, técnico e cultural: Direção Regional de Ambiente (Governo dos Açores); Centro de Investigação Transdisciplinar Cultura Espaço e Memória - Faculdade de Letras da Universidade do Porto; Reitoria da Universidade do Porto; Fundação para a Ciência e a Tecnologia; Comissão Nacional da UNESCO; ICOMOS-Portugal; Museu do Douro; Museu do Pico; Câmara Municipal da Madalena; Câmara Municipal de S. Roque do Pico. 



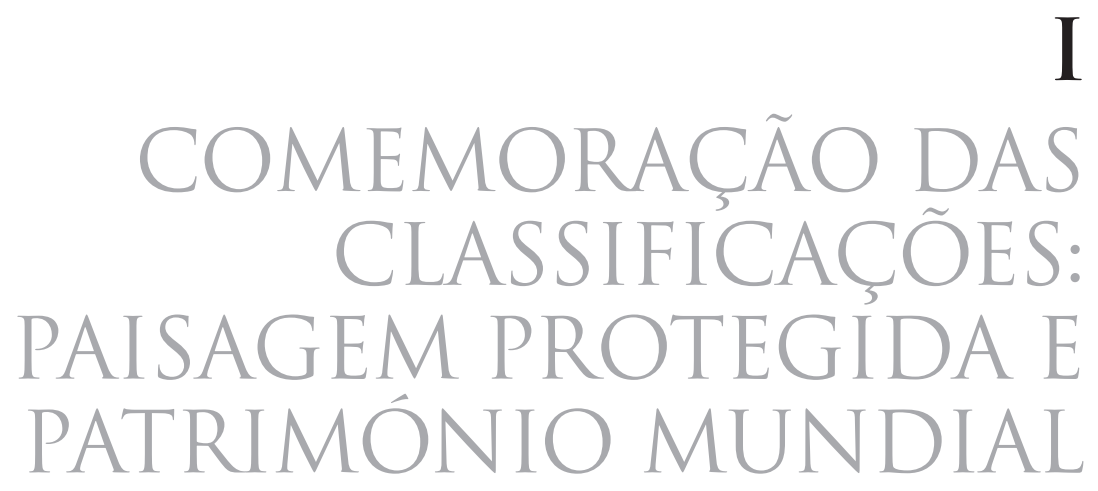





\section{SEMANA CULTURAL COMEMORATIVA DA EFEMÉRIDE}

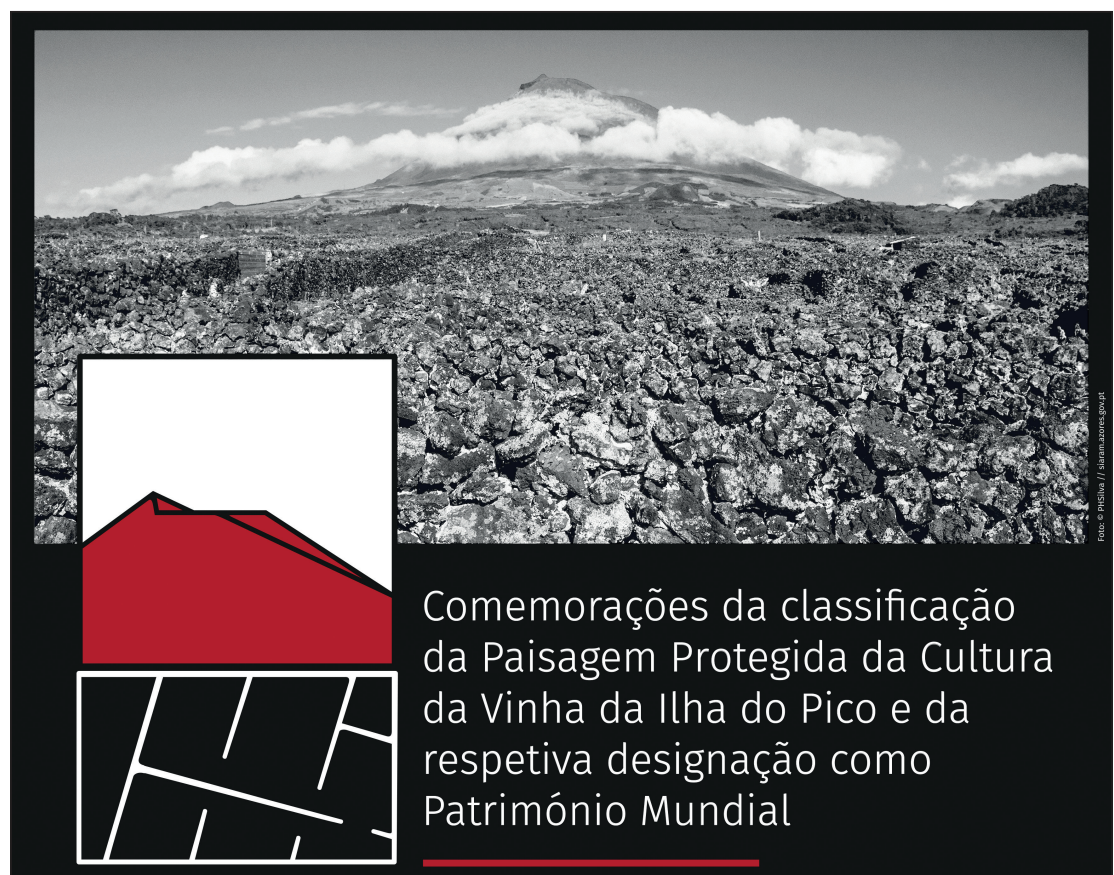

Salão Nobre da Câmara Municipal de São Roque

09 h30 - 13h00 I COLÓQUIO: A Paisagem da Cultura da Vinha da ilha do Pico - Contributos para o desenvolvimento sustentável

Auditório Municipal da Madalena

16h00 - 16h15 | Pico de Honra - edição especial do vinho Lajido, comemorativa dos 15 Anos da designação da Paisagem da Cultura da Vinha do Pico como Património Mundial

16h15 - 16h45 | Sessão solene evocativa das classificações da Paisagem da Cultura da Vinha do Pico - 23 Anos de área protegida e 15 Anos Património Mundial

$16 h 45$ - 17h45 | Exibição do documentário "Vinha do Pico - Paisagem de Oportunidades", de Paulo Henrique Silva

1128 de junho

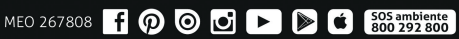

Fig. 1. Programa geral das Comemorações

Fonte: Parque Natural da Ilha do Pico 


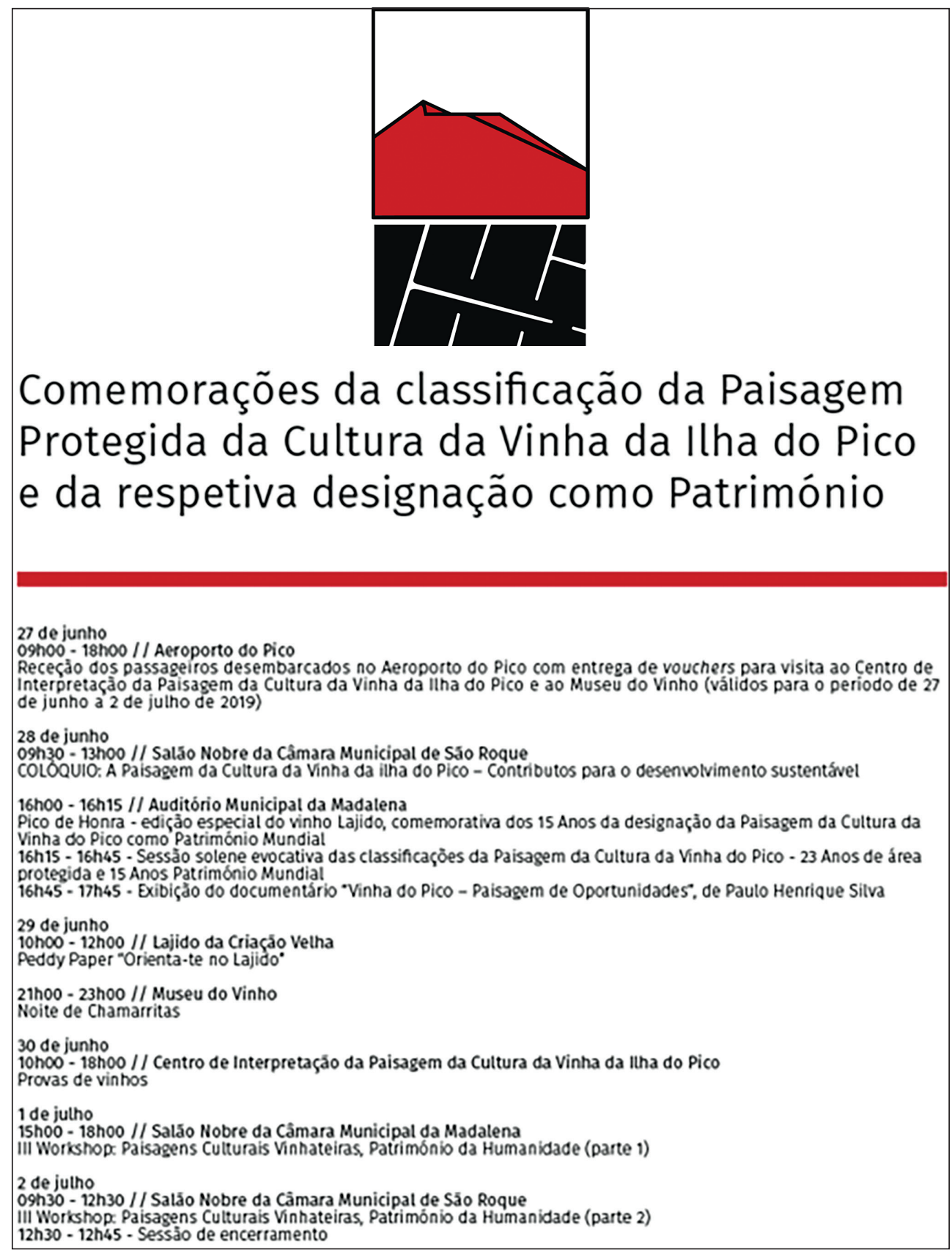

Fig. 2. Programa das Comemorações do dia 28 de junho Fonte: Parque Natural da Ilha do Pico 


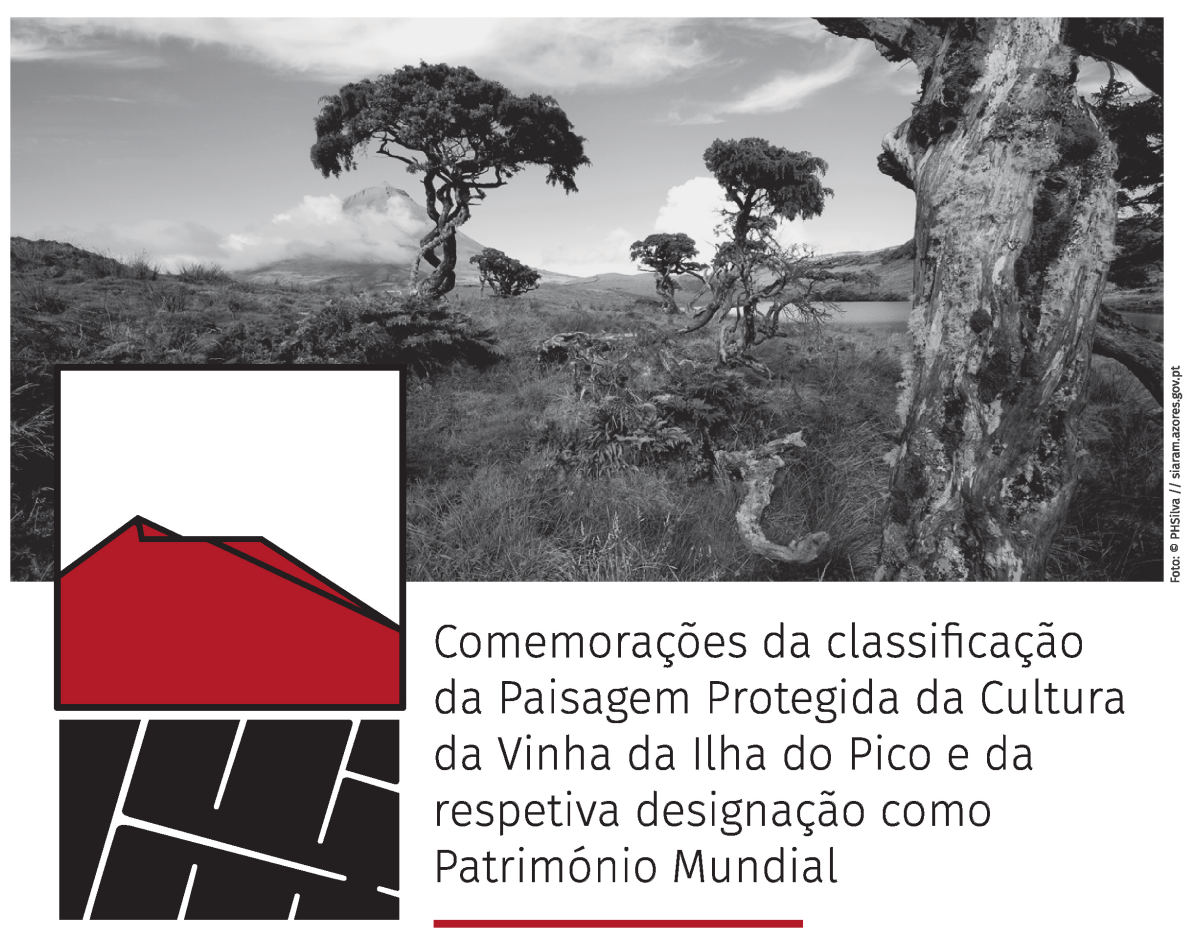

\section{Workshop: Paisagens Culturais Vinhateiras, Património da Humanidade}

1 de julho [Parte 1]

15 h00 - 18 h00 // Salão Nobre da Câmara Municipal da Madalena

2 de julho [Parte 2]

09 h30 - 12 h30 // Salão Nobre da Câmara Municipal de São Roque

Fig. 3. Programa do III Workshop Douro e Pico: Paisagens Culturais Vinhateiras, Património da Humanidade Fonte: Parque Natural da Ilha do Pico 



\section{REALIZACCÕES, RELEVÂNCIA, ADESÃO E IMPACTO DOS EVENTOS}

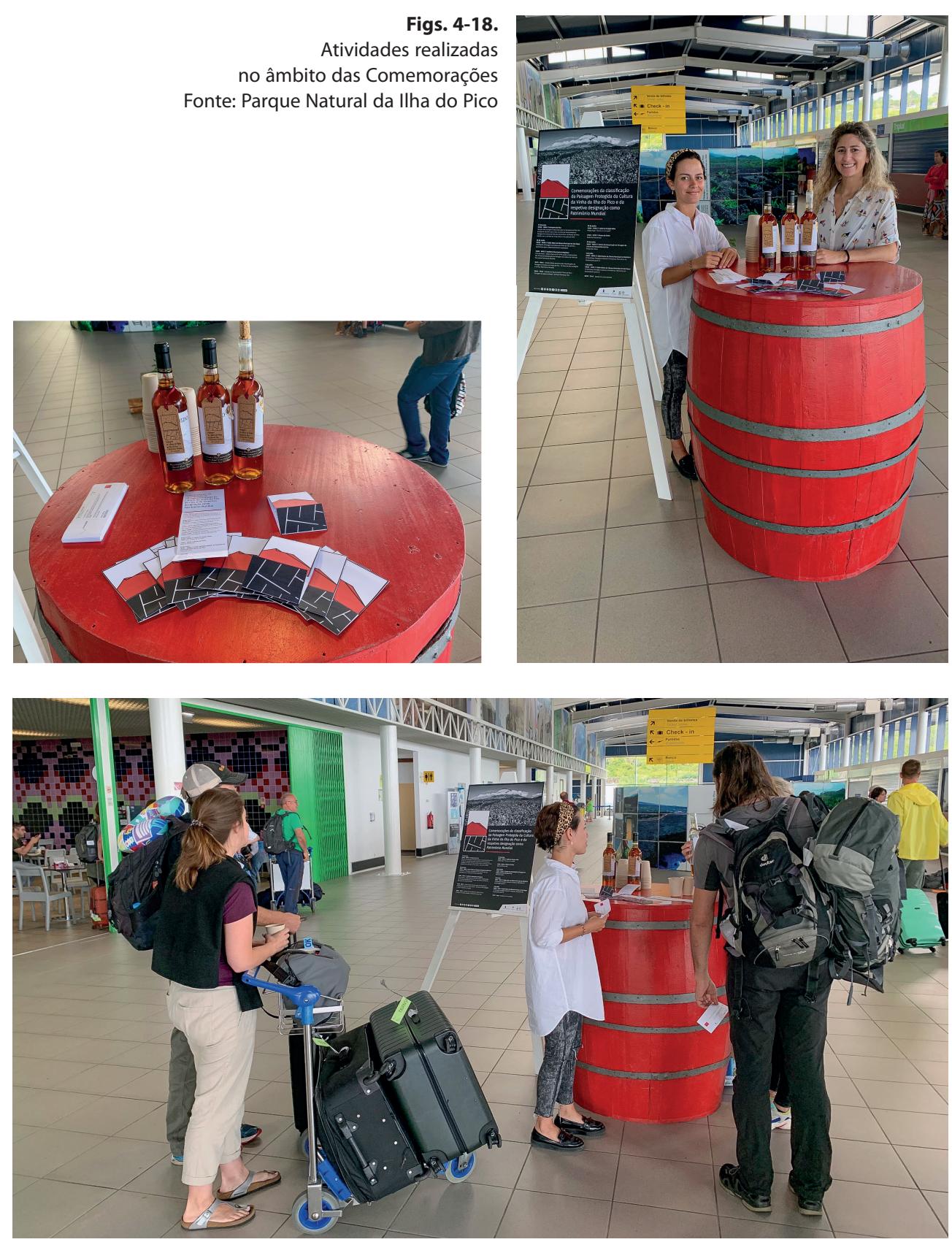



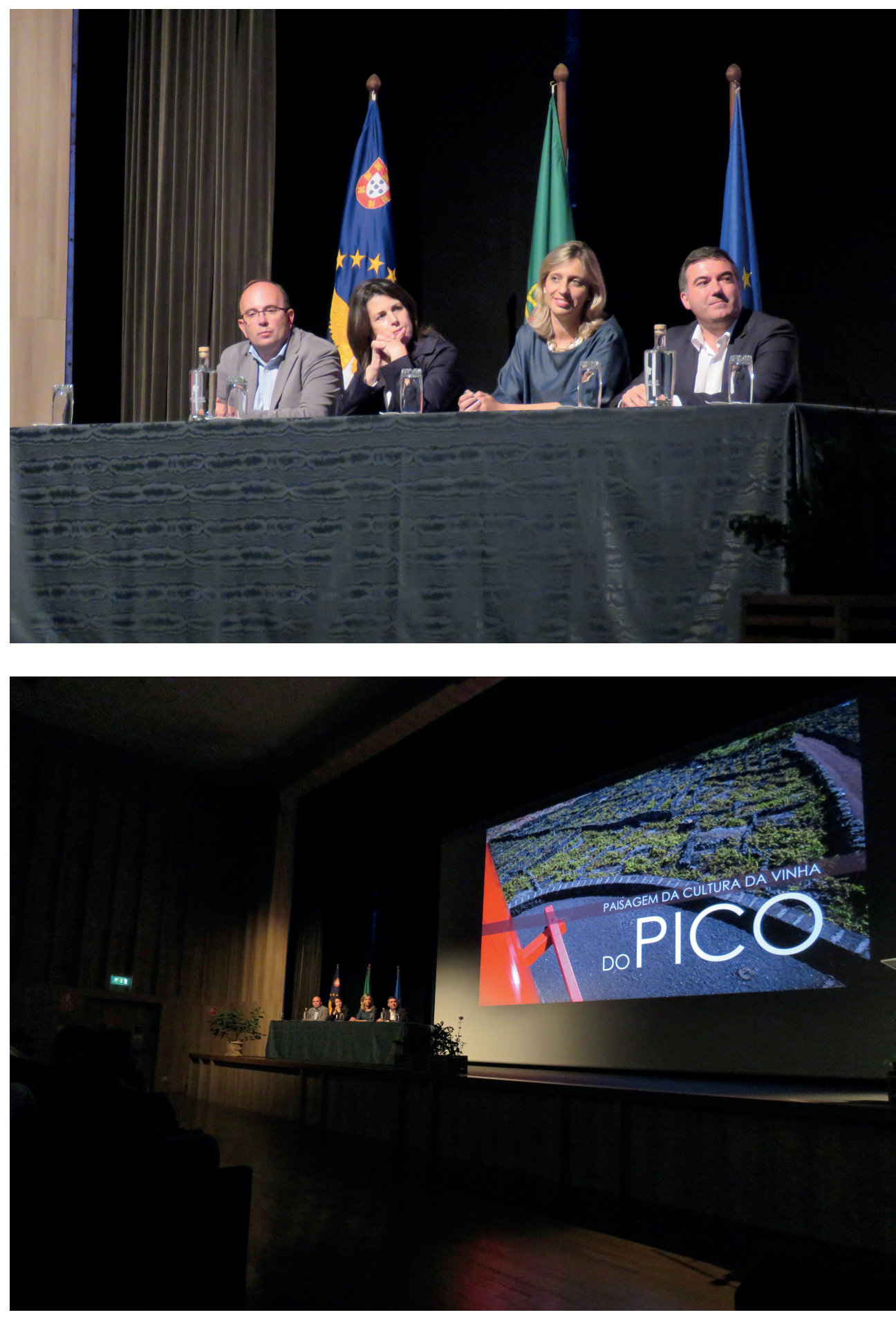

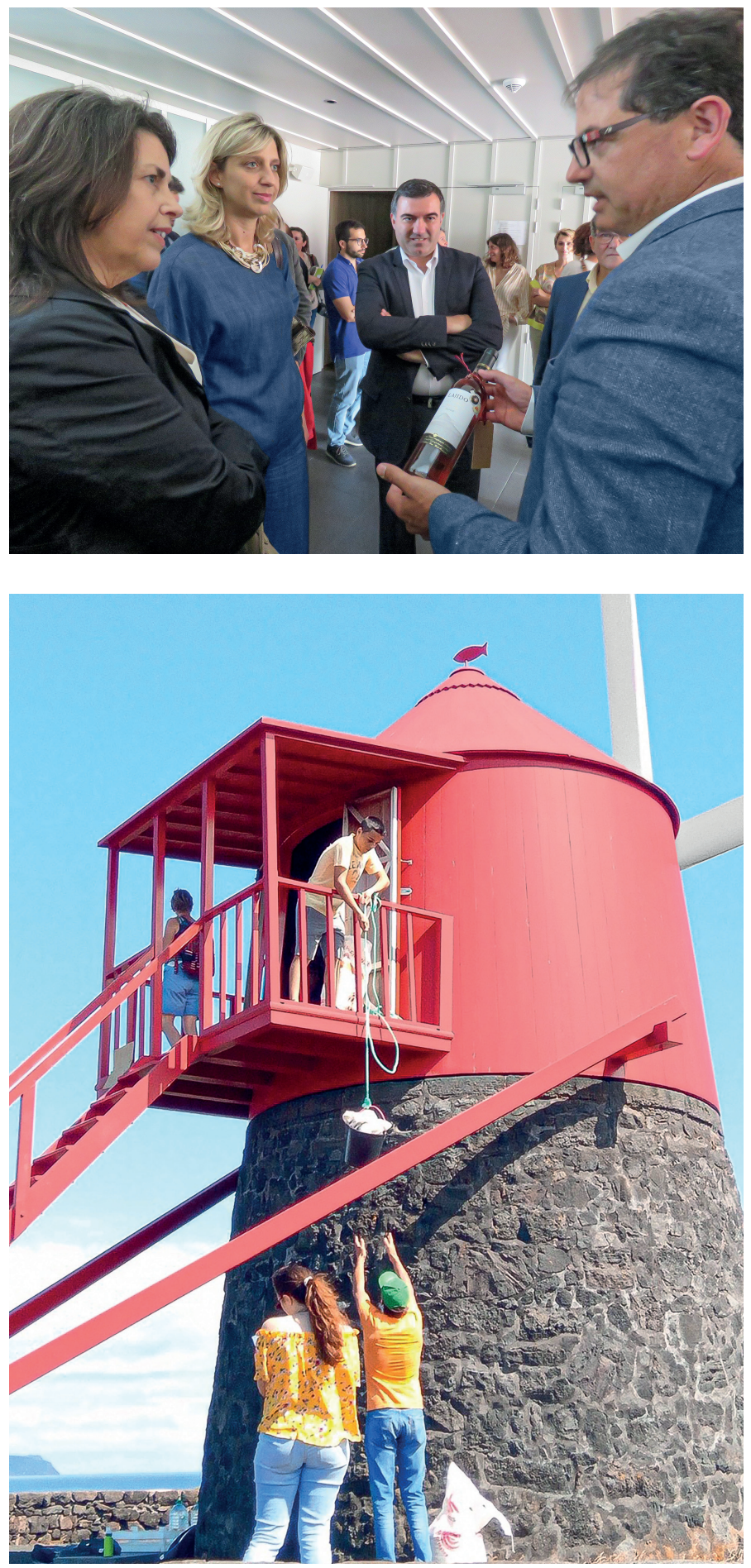

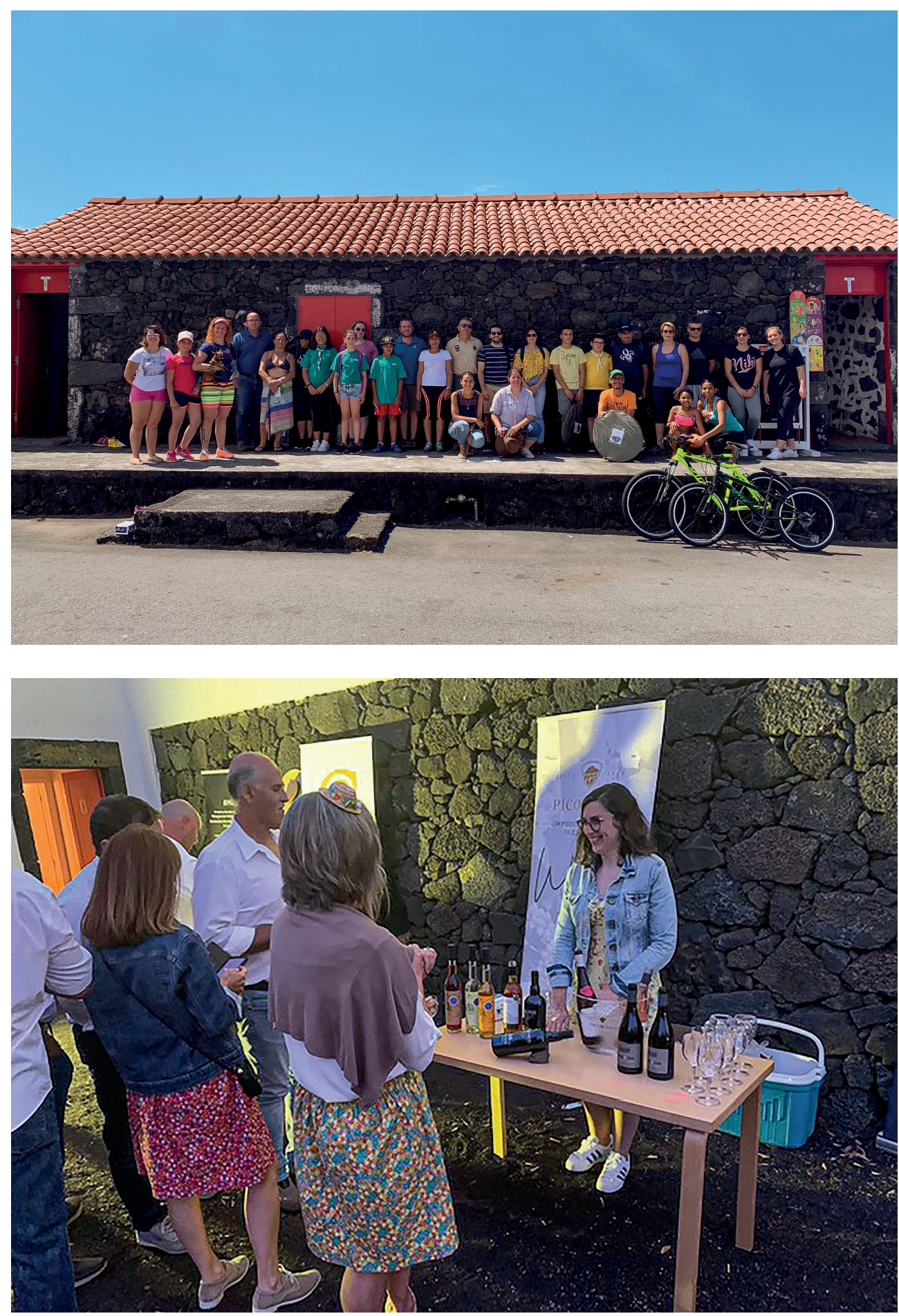

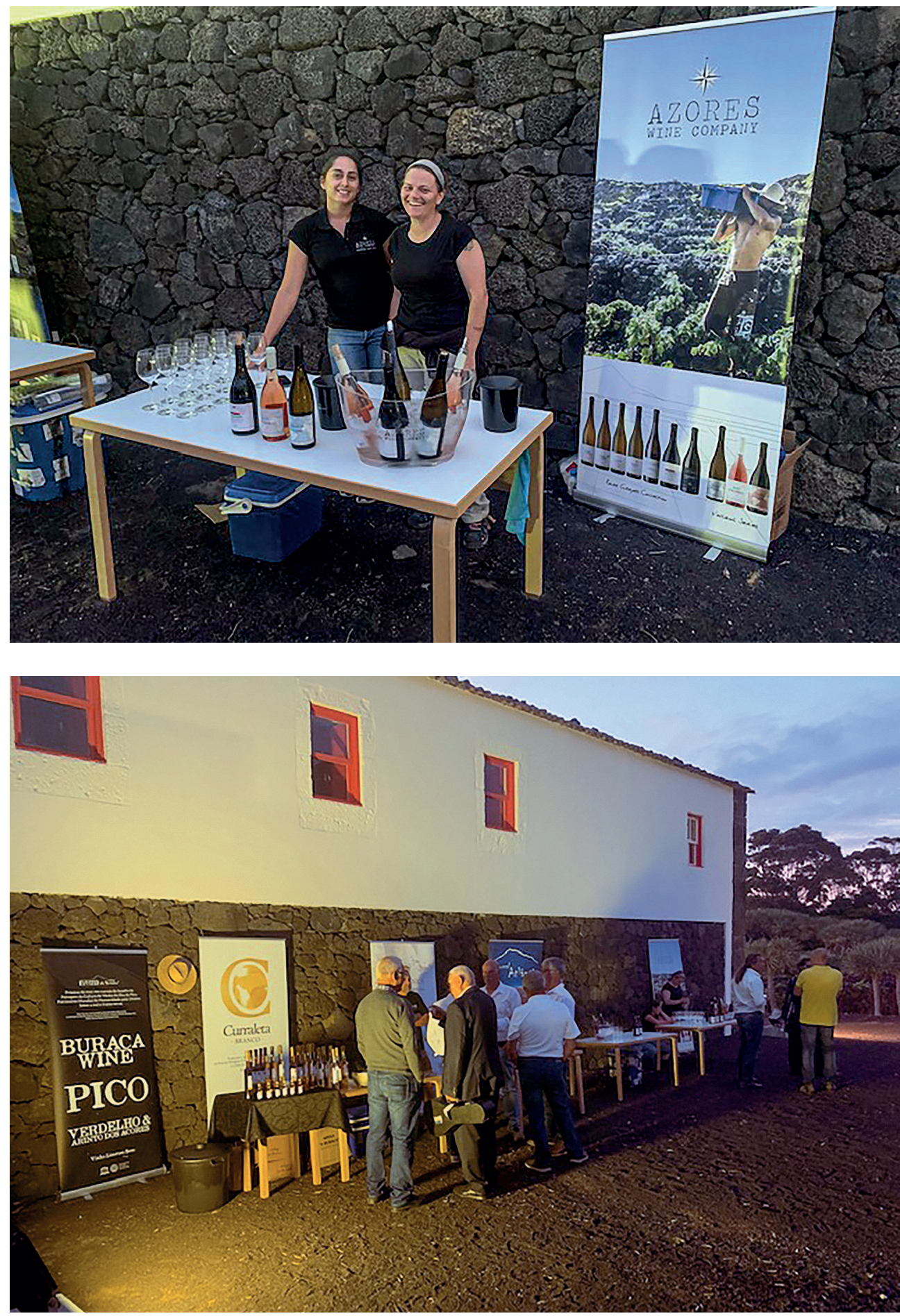

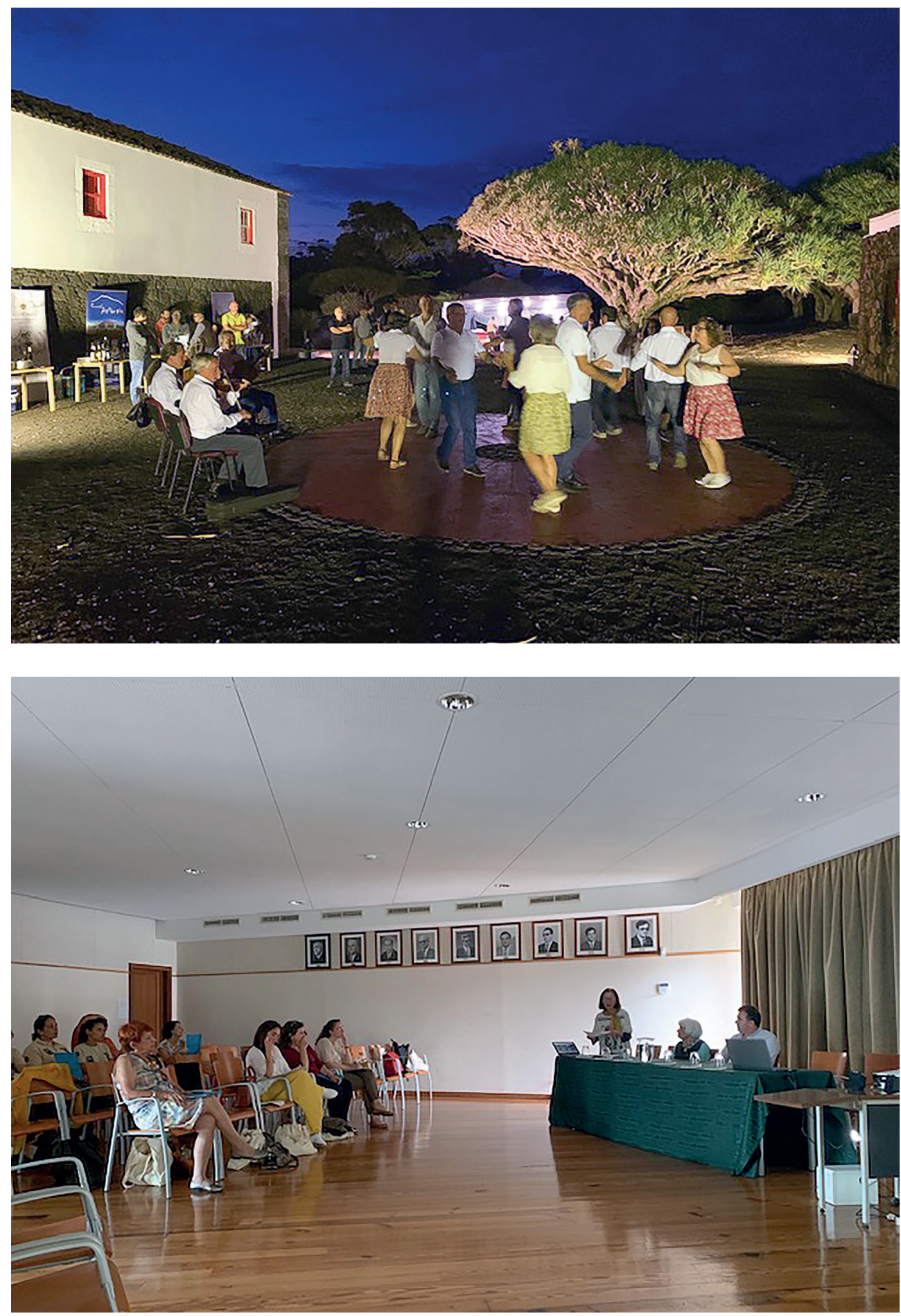

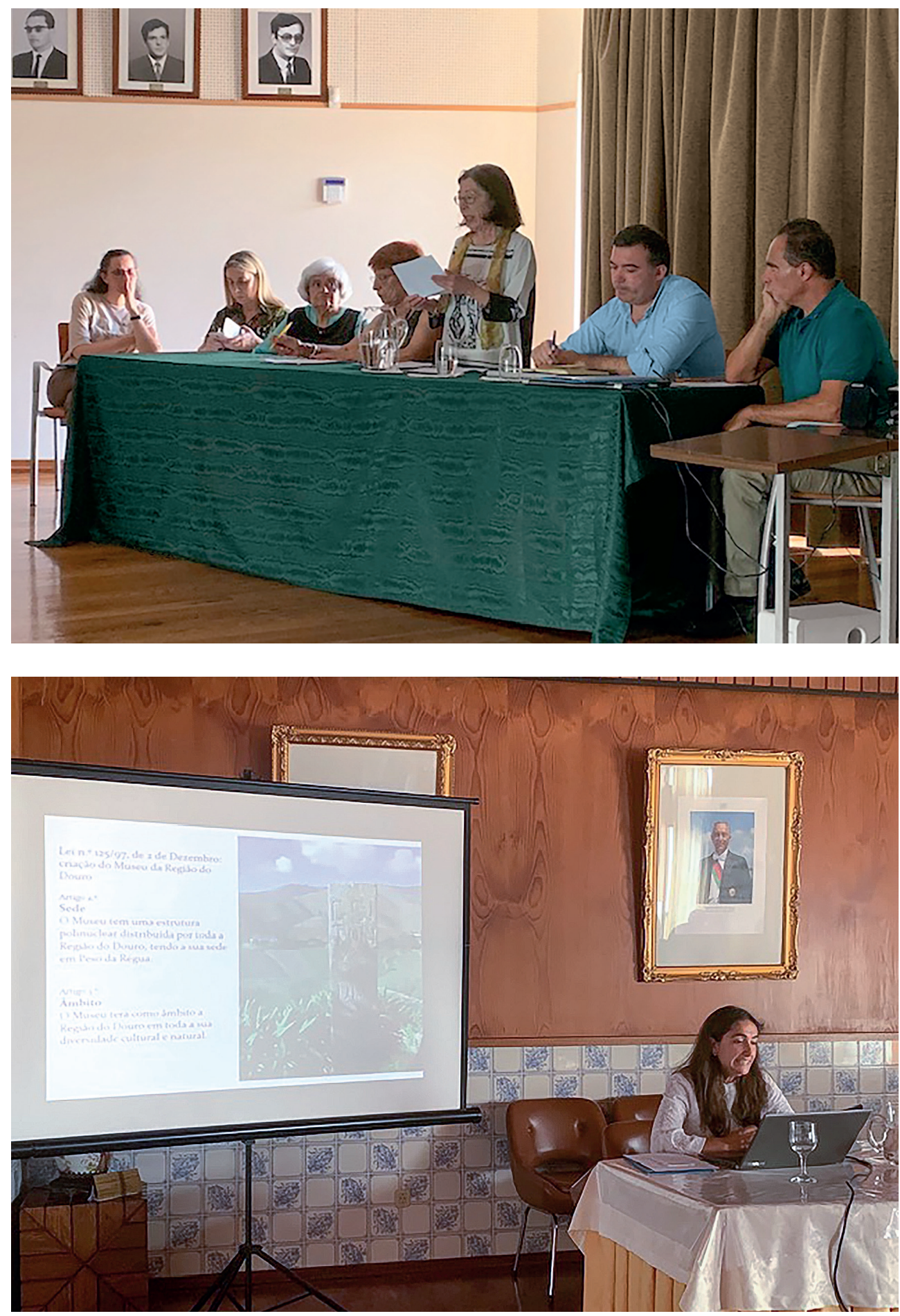



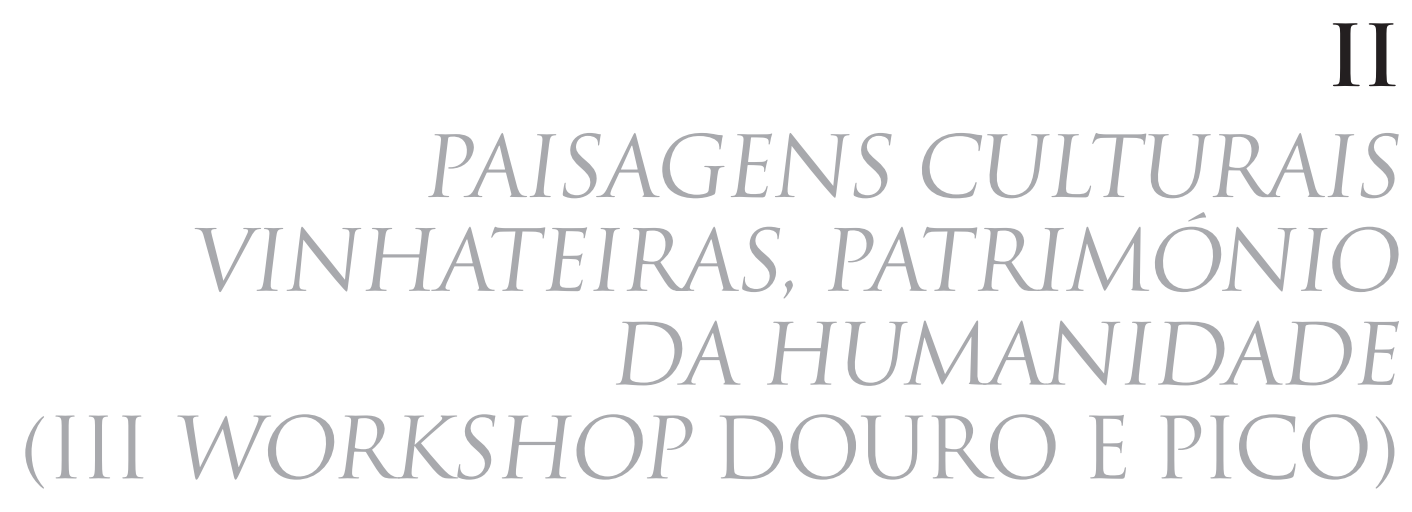





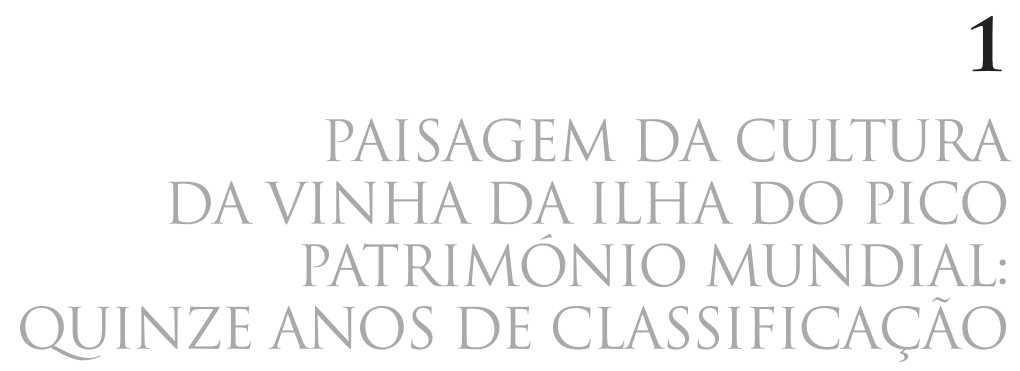





\title{
PAISAGEM DA CULTURA DA VINHA DA ILHA DO PICO - PRÉMIO NACIONAL DA PAISAGEM 2018
}

\author{
HERNÂNI JORGE*
}

\begin{abstract}
Resumo: A Paisagem da Cultura da Vinha da llha do Pico está, desde 1996, classificada como área de paisagem protegida, integrada no Parque Natural da llha do Pico e na Rede de Áreas Protegidas dos Açores. A extensão da área protegida e a sua inscrição pela UNESCO na lista do Património Mundial faz da Paisagem da Cultura da Vinha da Ilha do Pico um elemento fundamental da estratégia de desenvolvimento sustentável do Governo dos Açores.

Na edição de 2018 do Prémio Nacional de Paisagem, o Governo dos Açores concorreu com o projeto da Paisagem da Cultura da Vinha da Ilha do Pico, tendo vencido o referido prémio e como consequência representado Portugal no Prémio da Paisagem do Conselho da Europa 2018.
\end{abstract}

Palavras-chave: Paisagem; Património Mundial; Desenvolvimento sustentável; Cultura da vinha.

Abstract: The Landscape of the Pico Island Vineyard Culture has been classified since 1996, as a Protected Landscape Area, integrated into Pico Natural Park and at the Protected Areas Network of the Azores. The classification of this protected area as a World Heritage site by UNESCO makes the Landscape of the Pico Island Vineyard Culture a point of reference in the sustainable development strategy of the Government of the Azores.

At the 2018 edition of the National Landscape Award, the Government of the Azores presented the appliance of The Landscape of the Pico Island Vineyard Culture, who won the award, and was selected to represent Portugal at the Landscape Award of Council of Europe.

Keywords: Landscape; World Heritage; Sustainable development; Vineyard culture.

\section{PRÉMIO NACIONAL DA PAISAGEM}

O Prémio Nacional da Paisagem é promovido pelo Governo português, no quadro da Convenção Europeia da Paisagem e da Política Nacional de Arquitetura e Paisagem, com o objetivo de realçar abordagens territoriais promotoras da qualidade da paisagem e de incrementar a consciência cívica sobre o valor cultural das paisagens e sobre o papel que os diversos atores desempenham na sua transformação, bem como de selecionar um projeto nacional de referência que assegure a participação de Portugal no Prémio da Paisagem do Conselho da Europa.

Na edição de 2018, o Governo dos Açores concorreu com o projeto Paisagem da Cultura da Vinha da Ilha do Pico tendo vencido o referido prémio e, como consequência, representado Portugal no Prémio da Paisagem do Conselho da Europa 2018 que visa distinguir as políticas sustentáveis de proteção, gestão e ordenamento da paisagem.

* Diretor Regional do Ambiente/Secretaria Regional da Energia, Ambiente e Turismo do Governo Regional dos Açores. Email: Hernani.h.jorge@azores.gov.pt. 


\section{A PAISAGEM}

A Paisagem da Cultura da Vinha da Ilha do Pico difere das restantes paisagens açorianas devido à presença marcante e constante da montanha, à extrema pedregosidade do seu solo, à cor negra dominante e à diversificada vegetação natural. Esta paisagem, caracterizada pelo reticulado de currais ao longo da costa, reflete bem a evolução histórico-cultural de 5 séculos de ocupação humana de um território isolado e repleto de constrangimentos físicos e naturais que levaram ao desenvolvimento de processos de adaptação da população ao meio.

Fig. 1.

Paisagem da Cultura da Vinha da Ilha do Pico (Lajido da Criação Velha)

Fonte: José Feliciano

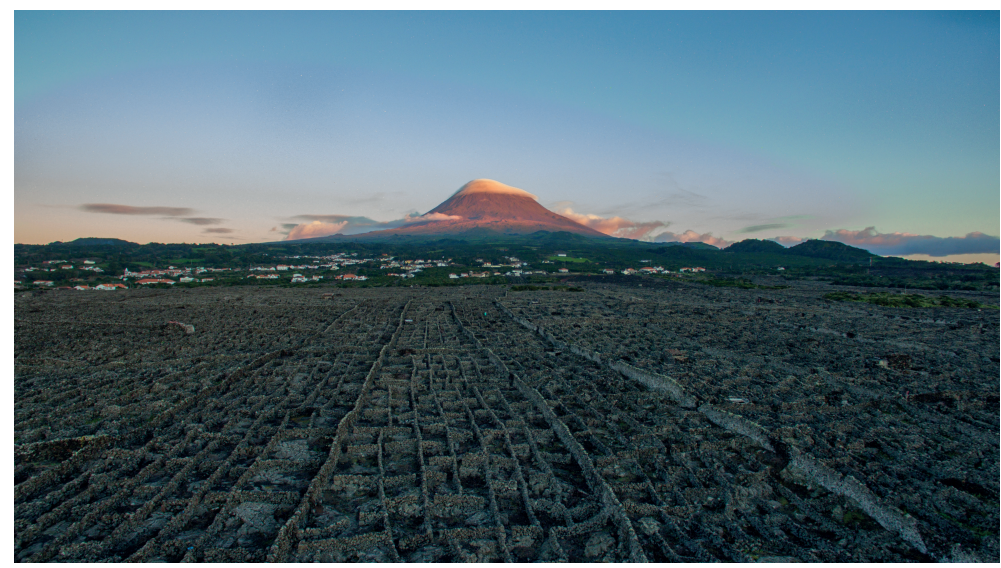

Entre os elementos naturais e culturais que conferem a esta paisagem um carácter único e distintivo, encontram-se muros negros de pedra seca, casas de abrigo, maroiços e descansadouros, adegas, alambiques e armazéns, poços de maré, portos, rilheiras e rola-pipas, espaços edificados, solares e património religioso, geo e biodiversidade, e manifestações socioculturais associadas às vindimas.

Depois de 200 anos de expansão da vitivinicultura, em meados do século XIX, as pragas do oídio e da filoxera levaram ao declínio da atividade, ao abandono das vinhas e à degradação da paisagem. As áreas de vinha foram substituídas por matos, por vezes de espécies exóticas invasoras. A crise trouxe a emigração, o fracionamento das grandes propriedades e a degradação do património edificado. Perante o abandono e a falta de ordenamento, proliferaram as dissonâncias arquitetónicas.

Assim, tornou-se necessário intervir com os objetivos de salvaguarda dos valores naturais, paisagísticos e culturais, e de promoção do desenvolvimento sustentado e da qualidade de vida das populações.

Com o foco na recuperação e consolidação de uma paisagem vitícola viva e no resgate da respetiva relevância social e económica, o Governo dos Açores desenvolveu, desde 1996, um conjunto diversificado de políticas e medidas na área da Paisa- 
gem da Vinha, com destaque para a reabilitação da cultura da vinha, o restauro do património edificado e a promoção da sustentabilidade.

\section{DESENVOLVIMENTO TERRITORIAL SUSTENTÁVEL}

A Paisagem da Cultura da Vinha da Ilha do Pico está, desde 1996, classificada como área de paisagem protegida, integrada no Parque Natural da Ilha do Pico e na Rede de Áreas Protegidas dos Açores. Ocupa uma área de 3 291,7 hectares e detém elementos naturais e culturais que lhe conferem um carácter único e distintivo.

A extensão da área protegida e a sua inscrição pela UNESCO na lista do Património Mundial faz da Paisagem da Cultura da Vinha da Ilha do Pico um elemento fundamental da estratégia de desenvolvimento sustentável do Governo dos Açores.

As políticas e medidas específicas desenvolvidas na Paisagem da Cultura da Vinha da Ilha do Pico foram essenciais para a salvaguarda dos valores naturais, paisagísticos e culturais desta paisagem, bem como para a promoção do desenvolvimento sustentado e da qualidade de vida das populações.

O Plano de Ordenamento da Paisagem Protegida da Cultura da Vinha da Ilha do Pico (POPPVIP) ${ }^{1}$ - primeiro e único plano de ordenamento de área protegida nos Açores - constitui um instrumento fundamental na preservação e recuperação da paisagem e dos seus elementos fundamentais, ao estabelecer um zonamento rigoroso de toda a área de intervenção, em função dos vários níveis de proteção. Este Plano delimitou áreas naturais e de intervenção específica para a salvaguarda de determinados habitats e espécies.

As medidas de apoio à reabilitação e manutenção da cultura tradicional da vinha em currais, e à reconstrução de ruínas e correção de dissonâncias arquitetónicas foram determinantes no estancar do abandono e degradação da paisagem e no alavancar de processos de regeneração das áreas de vinha e dos núcleos costeiros edificados. O aumento da área de vinha implicou a recuperação dos muros de pedra e a remoção de espécies exóticas invasoras em áreas extensas.

A reconstrução e reocupação de imóveis públicos contribuiu, igualmente, para a recuperação de ambientes degradados.

Com o retorno das pessoas e dos métodos tradicionais de uso dos solos à Paisagem da Vinha, voltam também as manifestações socioculturais associadas.

\footnotetext{
${ }^{1}$ O Decreto Regulamentar Regional n. ${ }^{\circ}$ 24/2006/A, de 13 de julho, (AÇORES. Secretaria Regional do Ambiente e do Mar, 2006) aprova o Plano de Ordenamento da Paisagem Protegida da Cultura da Vinha da Ilha do Pico em 2006, sendo posteriormente alterado em 2014 através do Decreto Regulamentar Regional n. ${ }^{\circ}$ 7/2014/A, de 6 de maio (AÇORES. Presidência do Governo, 2014).
} 


\section{VALOR EXEMPLAR}

As medidas implementadas em decorrência da classificação da Paisagem da Cultura da Vinha da Ilha do Pico, em 1996, consubstanciam uma estratégia de salvaguarda de valores naturais, paisagísticos e culturais, em termos exemplares e podem ser replicadas em outros territórios.

A classificação como área protegida e a inscrição como Património Mundial, associadas a um sistema de incentivos à reabilitação e manutenção da cultura tradicional da vinha em currais, bem como à reconstrução de imóveis em ruínas e à correção de dissonâncias arquitetónicas, constituem instrumentos promotores da sustentabilidade e das boas práticas e foram determinantes para reverter o abandono das vinhas e a degradação da paisagem.

Fig. 2.

Reabilitação de parcela de vinha

Fonte: Paulo Pereira

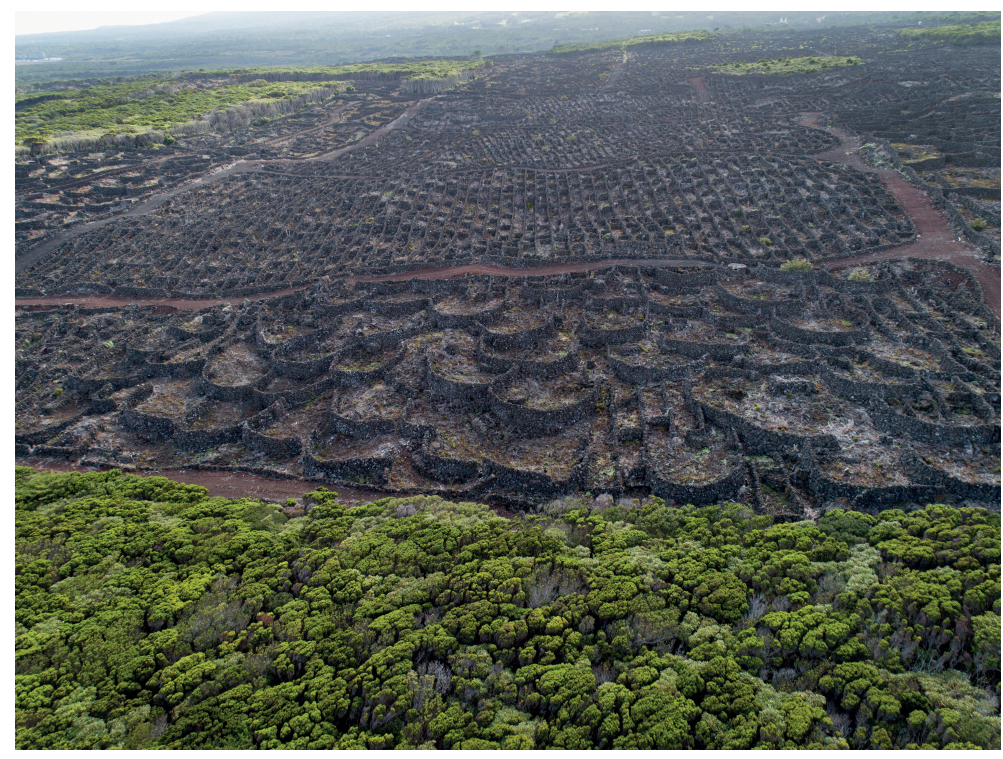

Assistiu-se a um aumento considerável da área de vinha e à requalificação do património edificado, ao ponto de hoje estar consolidada uma paisagem vitícola viva, com características únicas e uma crescente relevância económica e social.

Com base na experiência e no sucesso verificado no Pico, o Governo dos Açores criou, em 2014, um sistema de incentivos à manutenção de paisagens tradicionais da cultura da vinha e de pomares de espécies tradicionais, que abrange todas as ilhas dos Açores.

$\mathrm{Na}$ mesma linha, as normas complementares de execução do regime de apoio à reestruturação e reconversão de vinhas (VITIS) foram elaboradas com base na experiência obtida com o regime de apoios à reabilitação da cultura tradicional da vinha em currais na Paisagem da Cultura da Vinha da Ilha do Pico. 


\section{PARTICIPAÇÃO PÚBLICA}

A cidadania é essencial a qualquer processo de desenvolvimento sustentável, pelo que o envolvimento da população tem-se constituído como fator de sucesso na salvaguarda e reabilitação da Paisagem da Cultura da Vinha da Ilha do Pico.

Desde logo, o envolvimento nos processos de elaboração e alteração do Plano de Ordenamento da Paisagem Protegida da Cultura da Vinha da Ilha do Pico, que decorreram em 2006 e 2014, por via da realização de diversas sessões públicas nos três concelhos da ilha, com ampla participação dos cidadãos, bem como da disponibilização de toda a informação em portal da internet construído para o efeito, onde puderam formular questões ou solicitar esclarecimentos ${ }^{2}$.

Ao nível da participação cívica destacam-se as atividades desenvolvidas no âmbito dos programas Parque Escola e Parque Aberto, promovidas por equipas educativas do Parque Natural da Ilha do Pico nas escolas, nas áreas protegidas e nos centros de interpretação, com a finalidade de divulgar e promover o património natural.

O Parque Natural da Ilha do Pico tem 189 Parceiros para o Desenvolvimento Sustentável, projeto que visa o envolvimento das empresas e outras entidades na atividade dos Parques Naturais.

Por outro lado, o Parque Natural da Ilha do Pico dispõe de um conselho consultivo, que reúne semestralmente um conjunto de forças vivas no apoio à gestão das áreas protegidas.

Numa área de intervenção em que a quase totalidade da propriedade é privada, a sua regeneração só poderia acontecer com o envolvimento ativo da população. O Governo criou o estímulo, o resto é trabalho e suor dos homens e mulheres do Pico.

A Paisagem da Cultura da Vinha da Ilha do Pico, enquanto área protegida, integra a Rede de Áreas Protegidas dos Açores, que abrange 25\% do território emerso do arquipélago, em concretização de uma estratégia clara de salvaguarda do património natural e de promoção do desenvolvimento sustentável.

As medidas implementadas estão em linha com os objetivos da Política Nacional de Arquitetura e Paisagem e com a Convenção Europeia da Paisagem.

\section{SENSIBILIZAÇÃO}

Todo este processo nasce com a classificação da Paisagem da Cultura da Vinha da Ilha do Pico como área protegida, em 1996, em decorrência do abandono e degradação da paisagem, que ameaçava a própria identidade do povo do Pico.

As medidas implementadas limitaram-se a responder a esse sentimento popular que concebe a paisagem como um recurso relevante e como um fator identitário, quer para quem nela vive, quer para quem a visita, e enquadram-nos nos objetivos da Convenção Europeia da Paisagem.

\footnotetext{
${ }^{2}$ Veja-se http://siaram.azores.gov.pt/patrimonio-cultural/vinhas-pico/legislacao.html.
} 
O Centro de Interpretação da Paisagem da Vinha e o Museu do Vinho são espaços privilegiados para a promoção dos valores da paisagem, tendo recebido quase 110 mil visitantes desde que abriram, dos quais mais de 20 mil em 2017.

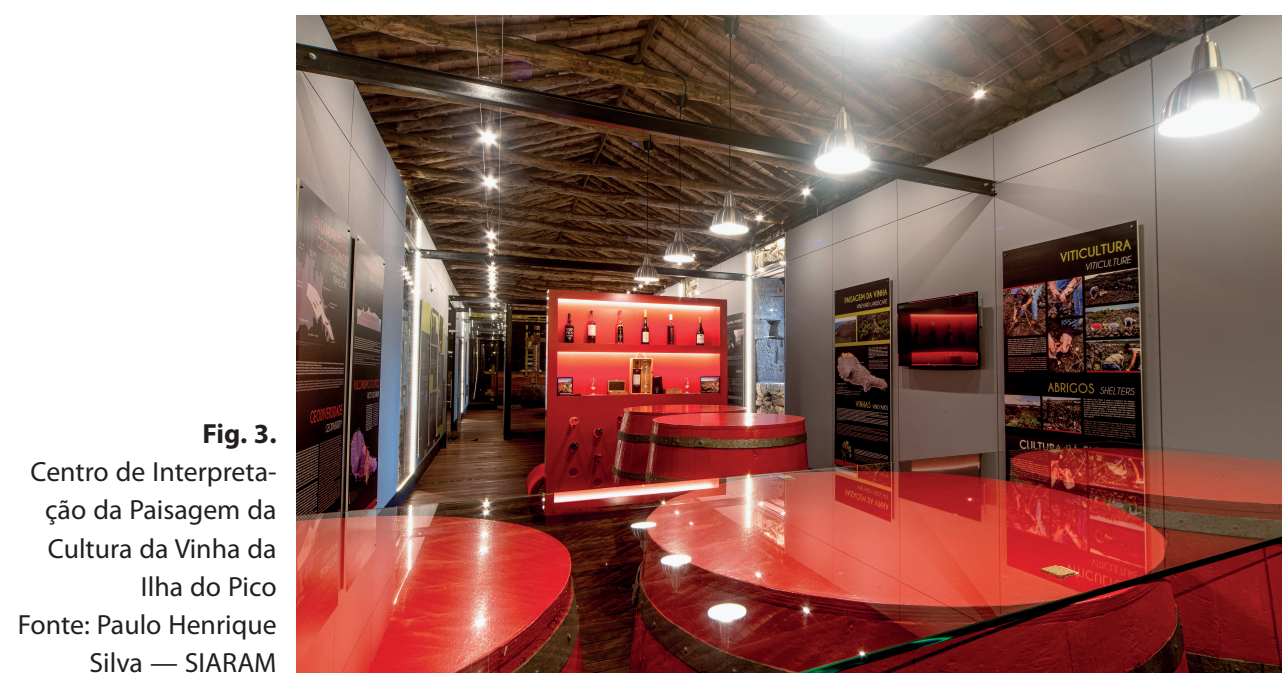

Ao nível da participação cívica e educação para a sustentabilidade, destaca-se o papel dos programas de âmbito regional, Parque Escola e Parque Aberto. O Parque Escola contempla uma vasta oferta de atividades direcionadas para o público escolar, em dois projetos: O Parque vai à Escola e A Escola vai ao Parque, tendo sido promovidas 122 atividades, abrangendo 3550 participantes, desde 2011. No mesmo período o Parque Aberto, enquanto programa que agrega atividades dirigidas à população em geral, desenvolvidas nas áreas protegidas e nos centros de interpretação, com a finalidade de divulgar e promover o património natural, contou com 171 atividades, envolvendo 5477 participantes.

Os cursos de Guias dos Parques Naturais dos Açores certificam profissionais para acompanhar e guiar grupos de pessoas às áreas protegidas e para a interpretação ambiental e cultural do meio envolvente, valorizando os serviços prestados e contribuindo para uma melhor compreensão das paisagens e do meio natural.

O facto de, desde 2015, os projetos de reabilitação das vinhas estarem a ser financiados pelo programa europeu VITIS contribui para afirmar a importância da Europa no desenvolvimento coletivo e na consolidação de uma identidade europeia. 


\section{RESULTADOS JÁ VERIFICADOS}

As políticas e medidas implementadas, desde 1996, na área da Paisagem da Cultura da Vinha da Ilha do Pico estancaram o abandono das vinhas e a degradação da paisagem e promoveram a recuperação e consolidação de uma paisagem vitícola viva.

No final de 2017, a área de vinha em produção era de 412 hectares, significativamente mais do que os 120 hectares existentes em 2004.

Está em curso a reabilitação de mais 399 hectares de vinhas, prevendo-se que a área em produção atinja os 811 hectares.

No final de 2017 existiam 279 explorações vitícolas em produção, comparando com as 170 de 2004.

Entre 2004 e 2017, a área média por exploração mais que duplicou, passando de 0,7 hectares para 1,47 hectares, e o número de beneficiários dos apoios à manutenção da vinha em currais passou de 72 para 279, enquanto o montante anual dos apoios financeiros passou de $93654 €$ para $875381 €$. Em 14 anos os apoios ascenderam a 4,61 milhões de euros.

Entre 2004 e 2012 foram apoiados 23 projetos de reconstrução de ruínas e de correção de dissonâncias arquitetónicas, correspondendo a $288687 €$ de compensação financeira.

O Governo Regional dos Açores promoveu a recuperação e reutilização de património público. As ruínas de conventos, moinhos, solares e armazéns reergueram-se como espaços de animação e interpretação da paisagem.

O Plano de Ordenamento da Paisagem Protegida da Cultura da Vinha da Ilha do Pico constituiu-se como um instrumento fundamental na preservação, recuperação e dinamização da área de intervenção, enquanto o Gabinete Técnico assegura a sua eficácia.

A produção e notoriedade do vinho do Pico têm aumentado, bem como o número de produtores e de marcas. Voltou a existir um mercado de exportação e estima-se que, em 2020, o vinho certificado ultrapasse 1 milhão de litros.

Surgem projetos de referência nos domínios do enoturismo e do turismo ativo.

Os dois espaços públicos de exposição e interpretação da paisagem receberam mais de 20 mil visitantes em 2017.

A intervenção foi reconhecida nos Green Project Awards 2016 e levou à escolha da Cidade do Vinho 2017.

\section{BIBLIOGRAFIA}

AÇORES. Presidência do Governo (2014). Decreto Regulamentar Regional n. ${ }^{\circ}$ 7/2014/A. «Diário da República Série I». 86 (2014-05-06) 2643-2663.

AÇORES. Secretaria Regional do Ambiente e do Mar (2006). Decreto Regulamentar Regional n. ${ }^{\circ}$ 24/2006/A. «Diário da República Série I». 134 (2006-07-13) 4892-4923. 

2

ENTIDADES DE GESTÃO DOS PATRIMÓNIOS MUNDIAIS PICO E ADV 



\title{
PAISAGEM DA CULTURA DA VINHA DA ILHA DO PICO: POTENCIALIDADES E ENLACES (PARCERIAS, TURISMO DE QUALIDADE, EDUCAÇÃO INCLUSIVA DE COMUNIDADES)
}

\author{
MANUEL PAULINO DA COSTA*
}

Resumo: A salvaguarda dos valores naturais, paisagísticos e culturais nas áreas da Paisagem da Cultura da Vinha da Ilha do Pico bem como a promoção do desenvolvimento sustentado e da qualidade de vida das populações motivaram a adoção de políticas públicas e a implementação de diversas medidas na área de intervenção, sobretudo ao longo das últimas duas décadas.

Um dos componentes destas políticas é, sem dúvida, a sensibilização dos decisores, empresários, habitantes e visitantes, bem como a comunidade estudantil, sobre a importância da paisagem. Neste contexto, foram promovidas várias iniciativas de sensibilização e de educação sobre a paisagem e o desenvolvimento sustentável.

Palavras-chave: Paisagem; Património Mundial; Desenvolvimento sustentável; Cultura da vinha.

Abstract: The protection of the natural, landscape, and cultural values in the areas of vineyard culture on Pico island, as well as the promotion of sustainable development and the quality of life of the populations, motivated the adoption of public policies and the implementation of various measures in those areas, especially over the last two decades.

One of the components of this Landscape Policy is undoubtedly the awareness of decision-makers, entrepreneurs, inhabitants, and visitors, as well as the student community, regarding the importance of the landscape. Within this context, several initiatives to raise awareness and to provide education regarding the landscape and sustainable development have been promoted.

Keywords: Landscape; World Heritage; Sustainable development; Vineyard culture.

\section{PARQUE NATURAL DA ILHA DO PICO}

Com o Decreto Legislativo Regional $n .^{\circ}$ 20/2008/A, de 9 de julho foi institucionalizado a figura de Parque Natural da Ilha do Pico, reunindo numa única estrutura a gestão de todas as áreas protegidas e classificadas da ilha do Pico ${ }^{1}$. O Parque Natural da Ilha do Pico, é o maior parque natural dos Açores, compreendendo 22 áreas protegidas, numa uma área territorial que abrange cerca de $35 \%$ da sua superfície terrestre, o que corresponde a cerca de $156 \mathrm{~km}^{2}$, à qual acrescem cerca de $79 \mathrm{~km}^{2}$ de área de proteção marinha.

\footnotetext{
* Parque Natural da Ilha do Pico — Direção Regional do Ambiente dos Açores. Lajido de Santa Luzia, 9940-108 São Roque do Pico. Email: Manuel.PS.Costa@azores.gov.pt.

${ }^{1}$ AÇORES. Assembleia Legislativa, 2008: 4277-4298.
} 


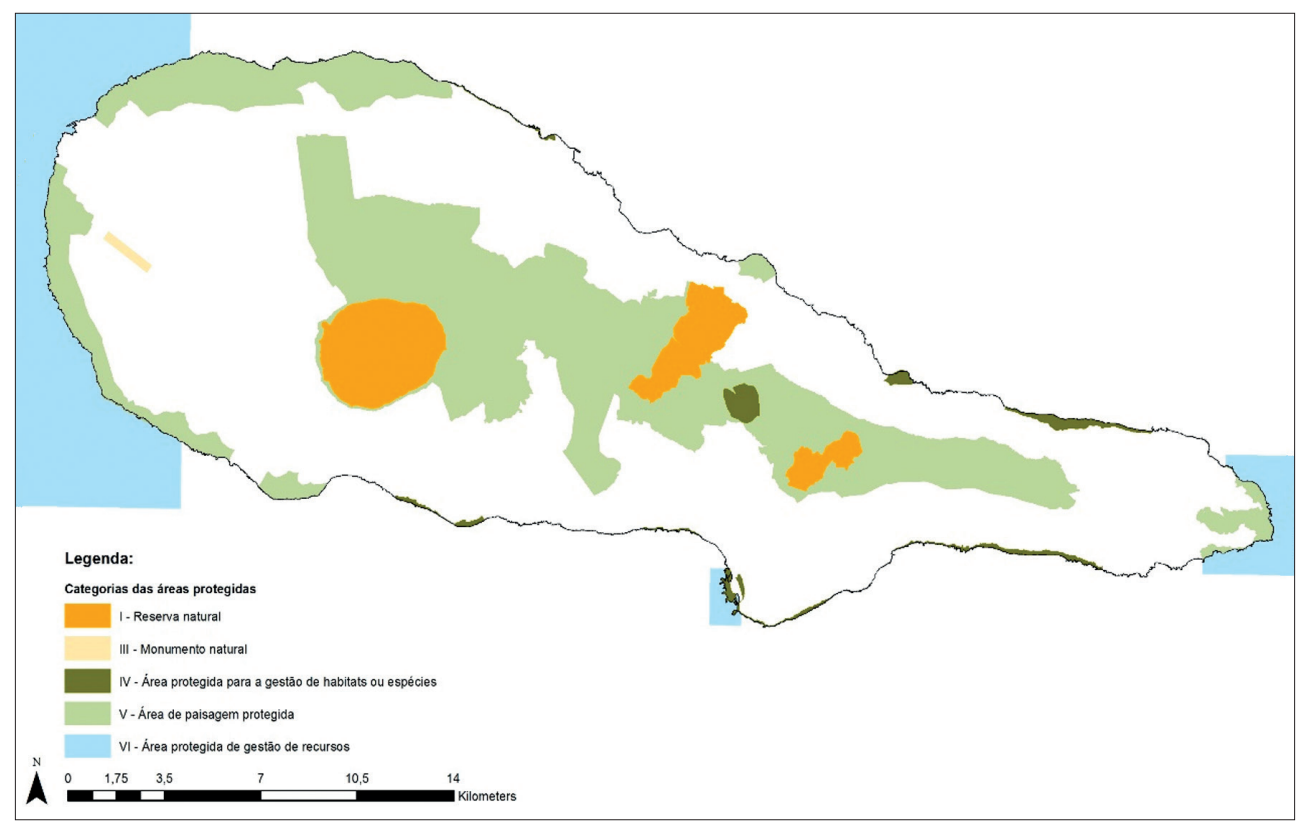

Fig. 1. Áreas protegidas pertencentes à categoria I (Reserva Natural); III (Monumento Natural); IV (Área protegida para gestão de habitats e espécies); V (Área de paisagem protegida) e VI (Área protegida de gestão de recursos). Fonte: Parque Natural da Ilha do Pico

O Parque Natural da Ilha do Pico é constituído por 4 Reservas Naturais, 1 Monumento Natural, 8 Áreas Protegidas para a Gestão de Habitats ou Espécies, 6 Áreas de Paisagem Protegida e 3 Áreas Protegidas de Gestão de Recursos. Engloba ainda diversas áreas classificadas, com particular destaque para 1 sítio Património Mundial da UNESCO, 5 Zonas Especiais de Conservação e 4 Zonas de Proteção Especial da Rede Natura 2000, 1 Sítio RAMSAR e 14 Geossítios do Geoparque Açores, Geoparque Mundial da UNESCO.

\section{A PAISAGEM DA CULTURA DA VINHA DA ILHA DO PICO}

A Paisagem da Cultura da Vinha da Ilha do Pico foi classificada em 1996 como Paisagem Protegida de Interesse Regional, pelo Decreto Legislativo Regional n. ${ }^{\circ}$ 12/96/A, de 27 de junho $^{2}$, e posteriormente em 2008, passou a integrar o Parque Natural da Ilha do Pico criado pelo Decreto Legislativo Regional n..$^{\circ}$ 20/2008/A, de 9 de julho ${ }^{3}$, ocupando, atualmente, uma área total de 3291,7 hectares, distribuída por cinco áreas protegidas: Área de Paisagem Protegida da Cultura da Vinha (zona Oeste), Área de Paisagem Pro-

\footnotetext{
2 AÇORES. Assembleia Legislativa Regional, 1996: 1648-1650.

${ }^{3}$ AÇORES. Assembleia Legislativa, 2008: 4277-4298.
} 


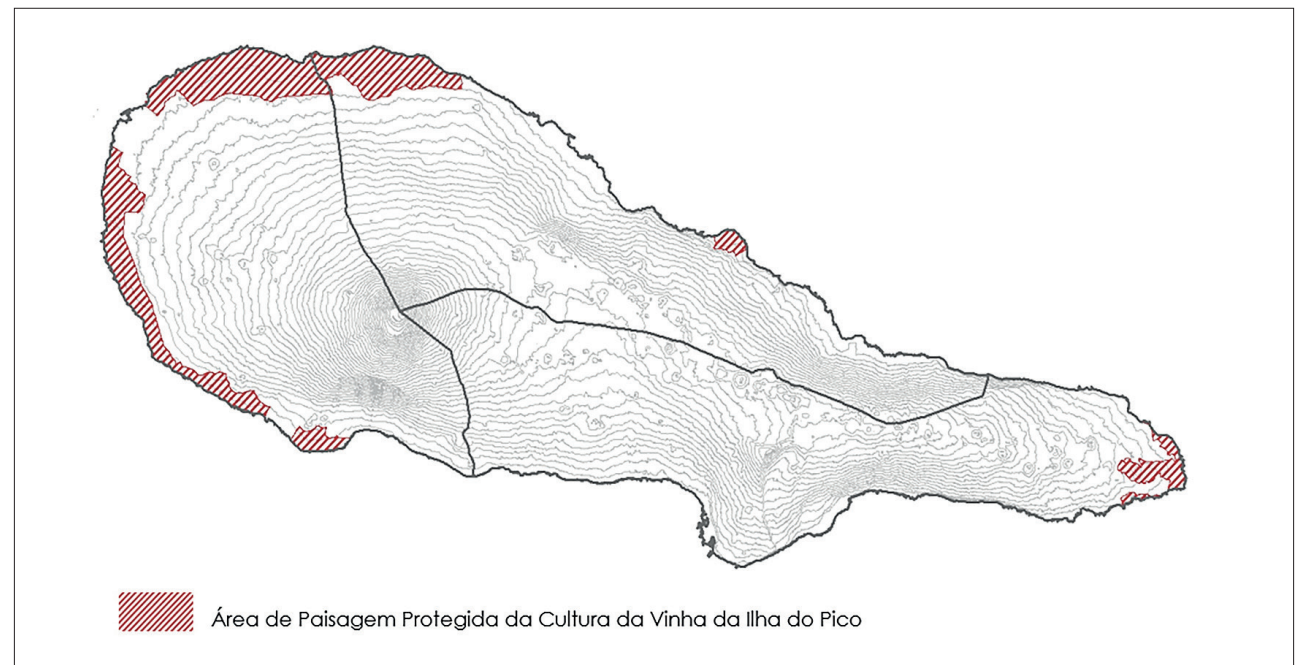

Fig. 2. Área de Paisagem Protegida da Cultura da Vinha da Ilha do Pico Fonte: Parque Natural da Ilha do Pico

tegida da Cultura da Vinha (zona Norte), Área de Paisagem Protegida da Cultura da Vinha (Ponta do Mistério), Área de Paisagem Protegida da Cultura da Vinha (Ponta da Ilha) e Área de Paisagem Protegida da Cultura da Vinha (São Mateus/São Caetano).

A inscrição da Paisagem da Cultura da Vinha da Ilha do Pico na lista do Património Mundial da UNESCO, em 2004, é o reconhecimento internacional de uma paisagem singular, refletindo uma versão única da atividade vitivinícola, numa pequena ilha vulcânica e a sua evolução desde a chegada dos primeiros povoadores no século XV.

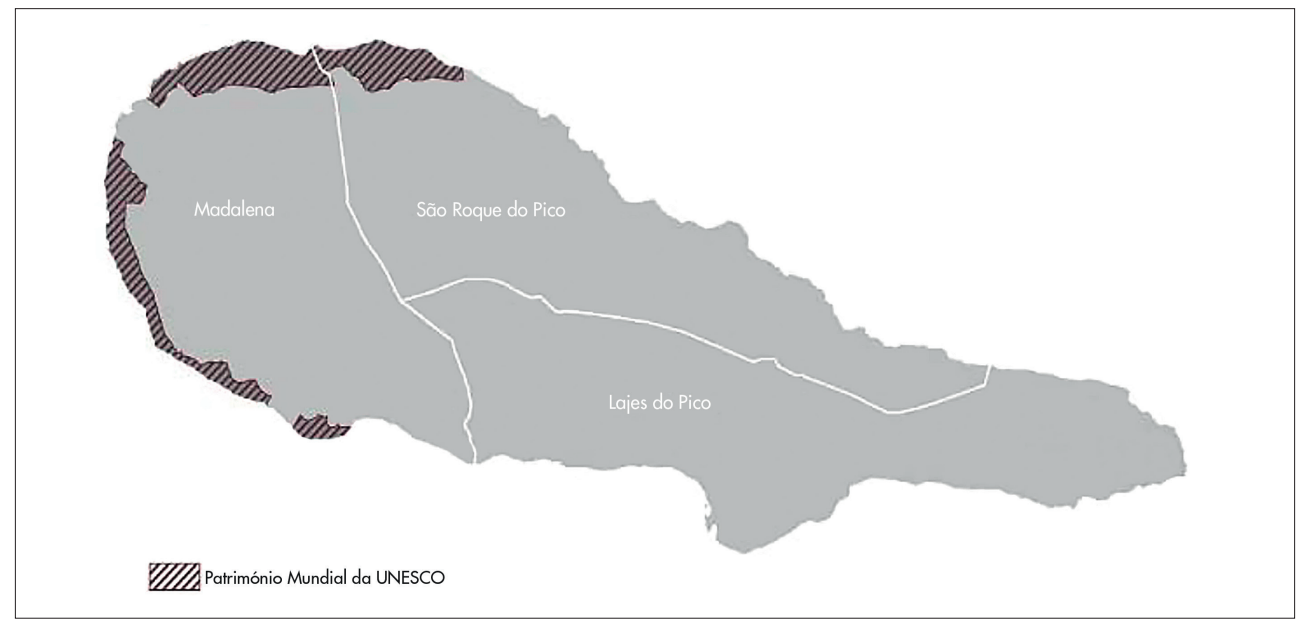

Fig. 3. Área da Paisagem da Cultura da Vinha da Ilha do Pico - Património Mundial da UNESCO Fonte: Parque Natural da Ilha do Pico 


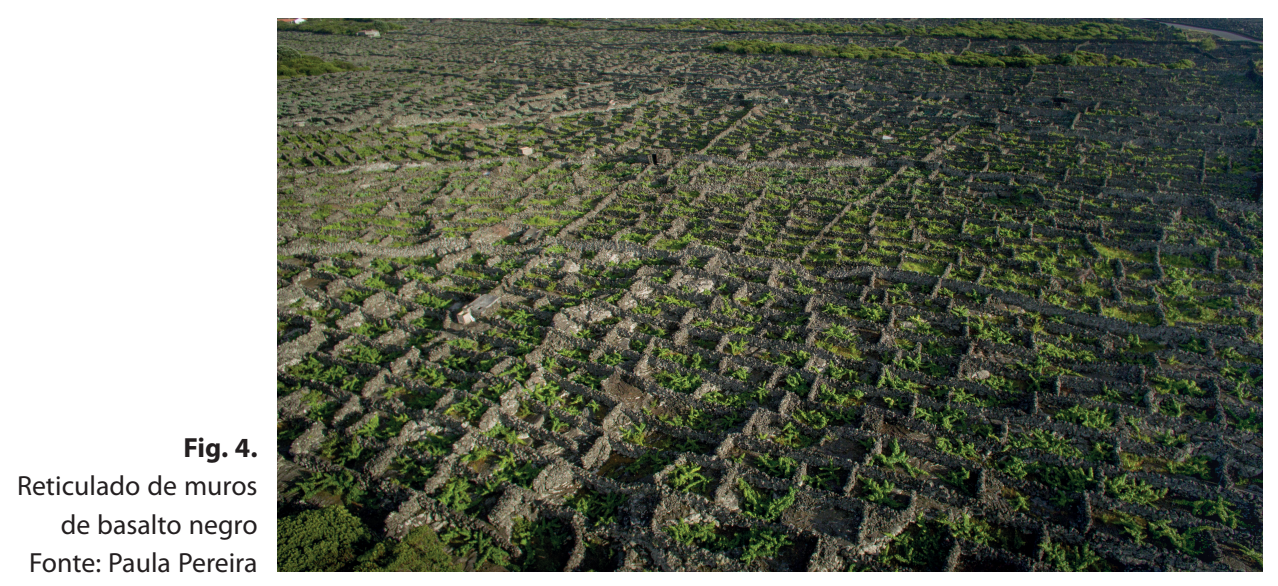

A área classificada como Património Mundial, cumprindo com os critérios (iii) e (v), abrange uma área de 987 hectares, envolvida por uma zona tampão de 1924 hectares, compreendendo a costa norte e oeste da ilha e, integra simultaneamente três áreas protegidas no Parque Natural da Ilha do Pico: Área de Paisagem Protegida da Cultura da Vinha (zona Oeste), Área de Paisagem Protegida da Cultura da Vinha (zona Norte) e Área de Paisagem Protegida da Cultura da Vinha (São Mateus/São Caetano).

Trata-se de uma paisagem que persistiu ao longo dos séculos, cuja configuração foi desenhada pela presença de atividade vitivinícola, tendo o seu início com a chegada dos povoadores à ilha no século XV. A sua singularidade decorre do elemento fundamental que a compõe: o reticulado de muros. Muros construídos para abrigar a planta de vinha do vento e do rossio, a única cultura possível de subsistir num solo improdutivo.

\section{A PAISAGEM E A COMUNIDADE}

A salvaguarda dos valores naturais, paisagísticos e culturais nas áreas da Paisagem da Cultura da Vinha da Ilha do Pico, bem como a promoção do desenvolvimento sustentado e da qualidade de vida das populações, motivaram a adoção de políticas públicas e a implementação de diversas medidas na área de intervenção, sobretudo ao longo das últimas duas décadas.

Um dos componentes destas políticas é, sem dúvida, a sensibilização dos decisores, empresários, habitantes e visitantes, bem como a comunidade estudantil, sobre a importância da paisagem. Neste contexto, foram promovidas várias iniciativas de sensibilização e de educação sobre a paisagem e o desenvolvimento sustentável.

\subsection{Programa Parque Aberto}

O Parque Aberto é um programa que agrega todas as atividades promovidas nas áreas dos Parques Naturais de Ilha, quer pelas equipas dos Parques, quer pelos seus 
parceiros, dirigidas para a população em geral. Este programa tem como finalidade divulgar e promover o património natural dos Parques Naturais dos Açores por toda a população, através da oferta de ações de promoção, sensibilização e conservação ambientais, científicas e de carácter sociocultural, ao longo de todo o ano. São organizadas atividades que envolvam e se adequam a toda a comunidade, com o intuito de sensibilizar e unir esforços, rumo a uma sociedade com hábitos cada vez mais ecológicos e sustentáveis. O Parque Aberto oferece ainda um conjunto de atividades direcionadas para grupos fechados e organizados, disponíveis de setembro a agosto, mediante marcação prévia.

Na Paisagem da Cultura da Vinha da Ilha do Pico, foram desenvolvidas inúmeras atividades no âmbito deste programa, passando por percursos pedestres interpretativos, workshops, tertúlias, palestras, provas de vinho, concertos musicais, dança, exposições, concursos fotográficos e a colaboração em três eventos de enorme importância na ilha:

- O festival Sentir o Pico, organizado anualmente pela Associação Comercial e Industrial da Ilha do Pico, tem como principal objetivo divulgar a ilha do Pico concentrando num único local aquilo que torna o Pico e os Açores num destino cada vez mais de referência a nível mundial com as tradições, a história, as suas gentes e como se relacionam com a paisagem.

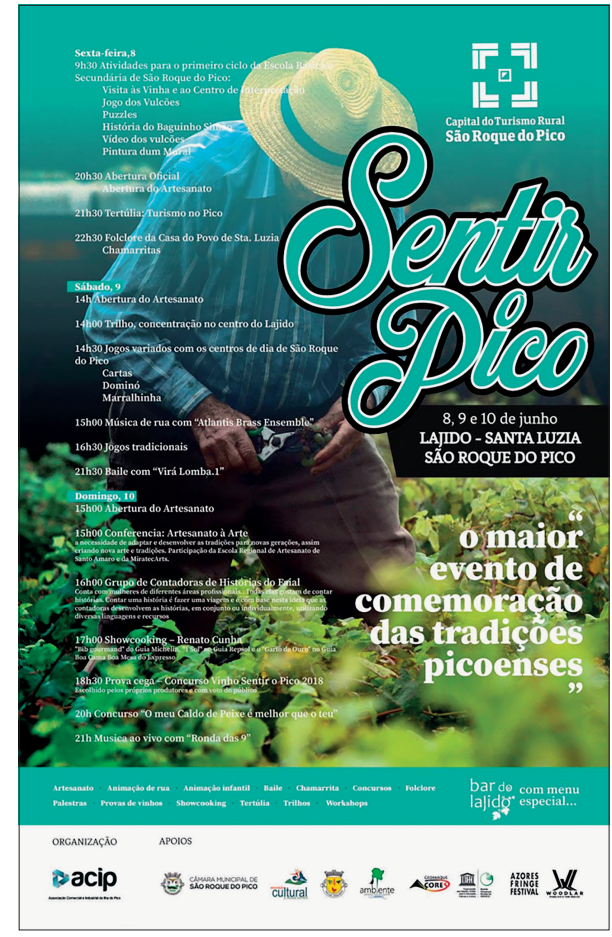

Fig. 5. Festival Sentir o Pico Fonte: ACIP 
- O Fringe Azores Festival, um festival de artes dos Açores, organizado pela associação MiratecArts, onde ao longo de um mês são promovidas diversas atividades artísticas dirigidas a toda a população.

- O Azores Triangle Adventure, um evento internacional de trail running, organizado pelo Clube Independente Atletismo Ilha Azul. É composto por três etapas que decorrem nas ilhas do Pico, São Jorge e Faial, sendo que a etapa do Pico é designada por Da Vinha à Montanha, onde os participantes têm a possibilidade de correr junto aos «currais» de vinha, ao longo das canadas do Lajido da Criação Velha, um dos núcleos mais importantes e mais bem preservados da Paisagem da Cultura da Vinha da Ilha do Pico.

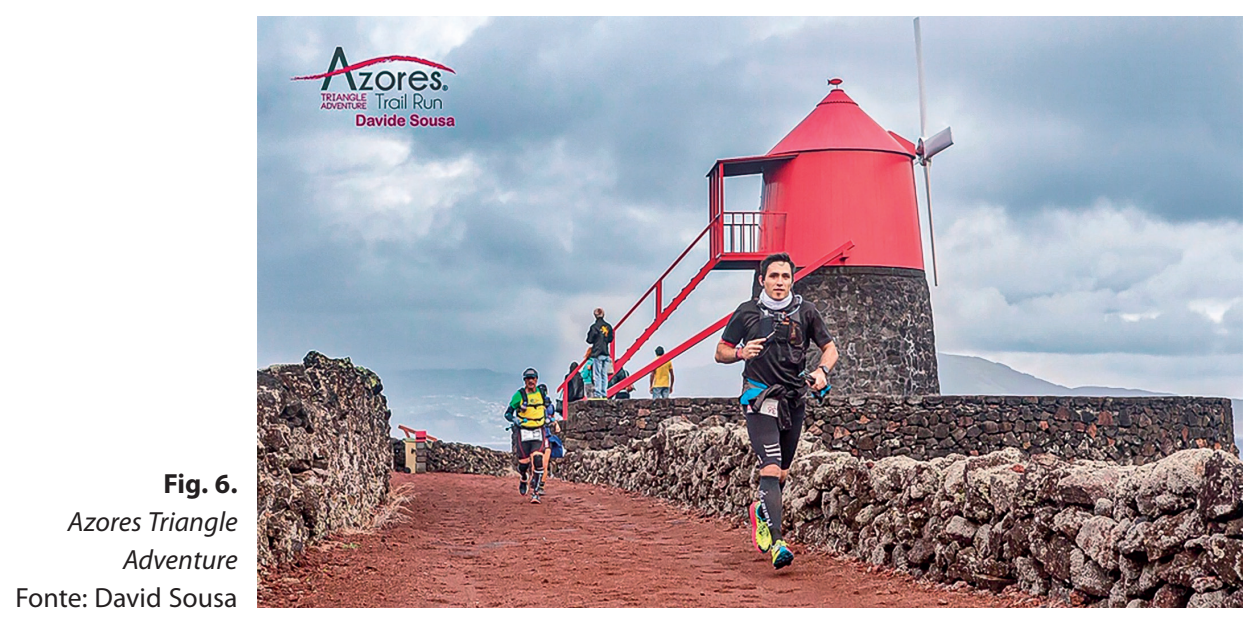

Ainda no âmbito do programa Parque Aberto, foi organizado no Centro de Interpretação da Paisagem da Cultura da Vinha da Ilha do Pico o evento À Descoberta dos Vinhos do Pico, onde os produtores locais tiveram a oportunidade de dar a conhecer os seus vinhos à comunidade ao longo de seis sessões.

Fig. 7.

À Descoberta dos Vinhos do Pico Fonte: Parque Natural da Ilha do Pico

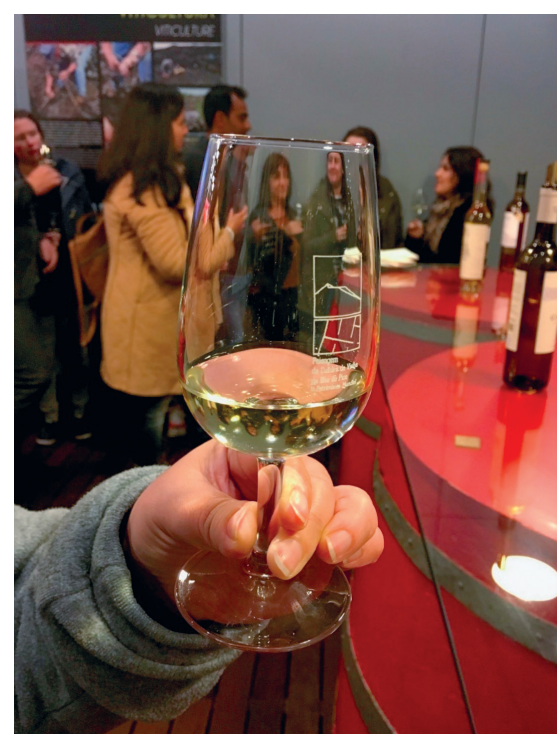




\subsection{Programa Parque Escola}

Na última década assistiu-se a um notável progresso da participação da sociedade civil e a um aumento da consciência das populações relativamente às questões ambientais. Ainda assim, é fundamental continuar a apostar na componente de educação ambiental nos contextos dos programas e atividades curriculares e extracurriculares dos vários graus de ensino.

A Paisagem da Cultura da Vinha da Ilha do Pico, enquanto área protegida constitui um legado natural e cultural inconfundível podendo servir como um laboratório de aprendizagem exímio para o conhecimento e proteção dos valores ambientais e culturais associados.

O programa Parque Escola é desenvolvido anualmente pela Direção Regional do Ambiente, através dos serviços educativos dos Parques Naturais de Ilha e da Rede de Centros Ambientais dos Açores, e disponibiliza à comunidade escolar uma oferta educativa diversificada e de carácter multidisciplinar, com ações dinamizadas dentro e fora do espaço escolar, sendo que para cada ação é apresentada a correlação com as áreas curriculares e conteúdos disciplinares, quer do Referencial Curricular para a Educação Básica na Região Autónoma dos Açores (CREB), quer do ensino secundário, permitindo que cada professor selecione as atividades que melhor se adequam à planificação das suas aulas. Este ano, a oferta foi complementada com a introdução de algumas ações para o ensino universitário.

Este programa concretiza os objetivos do Plano Regional de Educação e Sensibilização Ambiental dos Açores (PRESAA). Para além da rede de áreas protegidas, temas como a diversidade biológica, os recursos naturais, a geodiversidade, a eficiência energética, as alterações climáticas, os resíduos, a qualidade ambiental, o turismo de natureza, o património cultural e os sítios classificados - Rede Natura 2000, Reservas da Biosfera, Sítios Ramsar, Geoparque, entre outros - marcam presença nesta oferta educativa, em virtude da sua especial relevância na região.

A oferta do Parque Escola na ilha do Pico está organizada em duas formas: O Parque vai à Escola, onde os colaboradores dos serviços educativos dos Parque Natural deslocam-se às escolas para desenvolver as ações e A Escola vai ao Parque, que, por sua vez, subdivide-se em: A Escola vai ao Centro (ações que decorrem no Centro de Interpretação da Paisagem da Cultura da Vinha da Ilha do Pico) e em A Escola vai às Áreas Protegidas (ações educativas nas áreas protegidas e nos locais relevantes para a conservação da natureza).

O Parque Natural da Ilha do Pico oferece as seguintes atividades relacionadas com a Paisagem da Cultura da Vinha. No âmbito d'O Parque vai à Escola:

- Paisagem da Cultura da Vinha da Ilha do Pico - Património Mundial da UNESCO, uma sessão onde é explicada a importância da cultura da vinha, e 
onde são explicados com o recurso a uma maquete, alguns dos elementos mais significativos deste local.

- A viagem do Baguinho Simão. Através da leitura do conto da autoria de Susana Moura e ilustrações de Fábio Vieira, que relata os tempos antigos do dia a dia na vinha, vamos dar a conhecer algumas das curiosidades da Paisagem da Cultura da Vinha da Ilha do Pico. Esta atividade é complementada com a elaboração de um «Baguinho Simão», através da reutilização de materiais ${ }^{4}$.

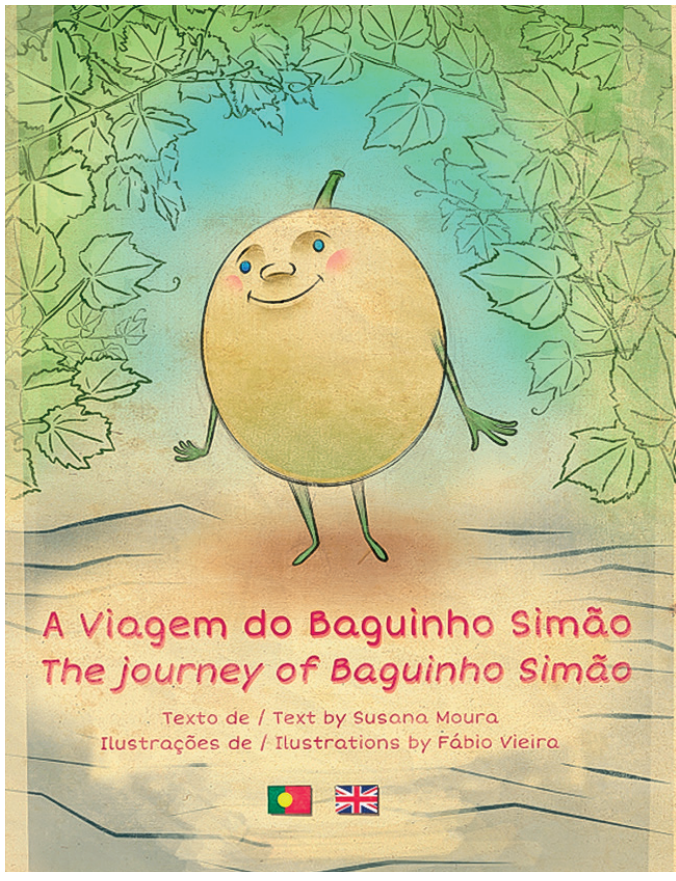

No âmbito d'A Escola vai ao Centro:

- Muros de História, onde são relacionados a geodiversidade, a biodiversidade e o património cultural associados aos muros de basalto negro.

- Visita do Coração do Lajido, que consiste numa visita interpretativa ao Lajido de Santa Luzia, um dos locais mais emblemáticos da paisagem.

No âmbito d'A Escola vai às Áreas Protegidas:

- Nos Trilhos do Parque Natural, onde é feita a interpretação ao longo dos trilhos, dos elementos característicos da Paisagem da Cultura da Vinha da Ilha do Pico.

${ }^{4}$ MOURA, txt., VIEIRA, il., 2015. 


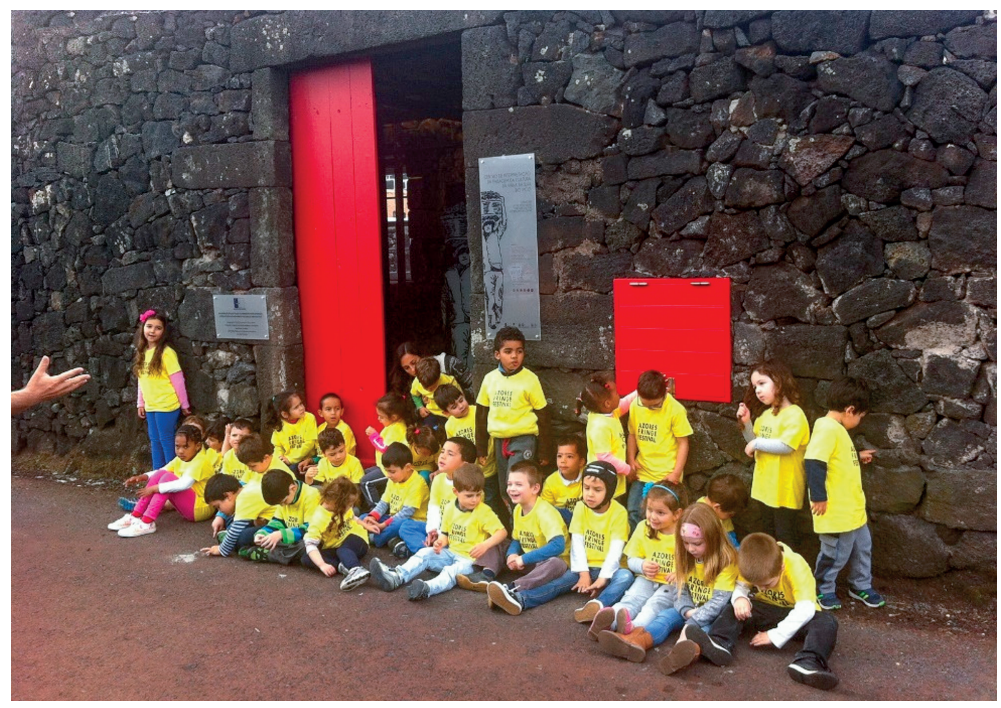

Fig. 9.

Atividade no âmbito d'A Escola vai ao Centro Fonte: Parque Natural da llha do Pico

\subsection{Parceiros para o Desenvolvimento Sustentável}

Este programa visa o envolvimento das empresas na atividade dos Parques Naturais, bem como na promoção do património natural e das boas práticas ambientais.

Ao assinarem um protocolo, com a entidade gestora, os parceiros passam a usufruir de um conjunto de descontos nos centros de visitantes do parque, bem como a sua promoção através dos canais de divulgação dos Parques Naturais.

Passados 15 anos da sua classificação como Património Mundial da UNESCO, esta paisagem transformou-se num local de oportunidades, onde as tradições e o património fazem parte do presente e onde aos poucos a cultura da vinha e do vinho voltam a ganhar importância.

Tornou-se uma paisagem viva, que funciona como polo dinamizador da economia local.

\section{BIBLIOGRAFIA}

AÇORES. Assembleia Legislativa (2008). Decreto Legislativo Regional n. ${ }^{\circ}$ 20/2008/A. «Diário da República Série I». 131 (2008-07-09) 4277-4298.

AÇORES. Assembleia Legislativa Regional (1996). Decreto Legislativo Regional n. ${ }^{\circ}$ 12/96/A. «Diário da República Série I-A». 147 (1996-06-27) 1648-1650.

MOURA, Susana, txt.; VIEIRA, Fábio, il. (2015). A viagem do Baguinho Simão. The journey of Baguinho Simão. Tradução de Lídia Melo. [Açores]: Governo Regional - Secretaria Regional da Agricultura e Ambiente. 



\title{
PICO E DOURO - PATRIMÓNIOS DA HUMANIDADE: POTENCIALIDADES E ENLACES (PARCERIAS, TURISMO DE QUALIDADE, EDUCAÇÃO INCLUSIVA DE COMUNIDADES)
}

\author{
HELENA TELES*
}

Resumo: O Sistema de Gestão do Alto Douro Vinhateiro assenta numa cultura de parcerias e de proximidade com o território dando primazia ao trabalho em rede e ao envolvimento dos atores locais, regionais, nacionais e internacionais. Esta abordagem tem sido determinante na disseminação do conhecimento sobre o Património Mundial e na consolidação da identidade coletiva do Douro, quer pela via da inclusão das comunidades, quer pela otimização e usufruto da chancela UNESCO como um ativo económico capaz de potenciar o incremento do turismo de qualidade e no desenvolvimento sustentável e integrado da região.

Palavras-chave: Sistema de Gestão do Alto Douro Vinhateiro; Cultura de parcerias; Desenvolvimento sustentável e integrado.

\begin{abstract}
Abstrat: The Alto Douro Wine Region Management System is having based on partnership culture and closeness to territory, giving priority to networking and engagement of local, regional, national and international actors. This approach has been crucial for the dissemination of knowledge about World Heritage and consolidation of Douro's collective identity, either through the inclusion of communities, or through the optimization and use of the UNESCO classification as an economic asset, capable of enhancing quality tourism and the sustainable and cohesive development of the region.
\end{abstract}

Keywords: Alto Douro Wine management system; Partnership culture; Sustainable and cohesive development.

\section{INTRODUÇÃO}

Dando sequência à cooperação estabelecida com o CITCEM e o Sítio Paisagem Protegida da Cultura da Vinha da Ilha do Pico, a Missão Douro participou no III Workshop, realizado na ilha do Pico e integrado nas comemorações dos 15 anos da sua classificação pela UNESCO.

Mais do que um contributo para o desenvolvimento dos trabalhos levados a cabo no âmbito deste projeto transdisciplinar, o Alto Douro Vinhateiro (ADV) jun-

\footnotetext{
* Comissão de Coordenação e Desenvolvimento Regional do Norte - Estrutura Sub-regional de Vila Real/Missão Douro.Email: helena.teles@ccdr-n.pt.
} 
ta-se ao tributo que este evento representa na valorização e promoção do património vitivinícola nacional.

Não obstante se tratar de duas realidades distintas, quer no que toca às técnicas e sistemas de cultivo e sua evolução histórica, quer aos contextos sociais e económicos dos territórios abrangidos, Douro e Pico partilham o mesmo desafio: o desenvolvimento sustentável e coeso das suas comunidades sob a égide de uma chancela universal, a partir de uma gestão de base territorial, de proximidade, de envolvimento, de cooperação entre todos os interlocutores.

Esta abordagem encontra-se claramente plasmada no tema deste terceiro encontro: Pico e Douro - Patrimónios da Humanidade: Potencialidades e Enlaces (parcerias, turismo de qualidade, educação inclusiva de comunidades), propondo-se uma comunicação onde, a par da caracterização dos valores únicos e identitários do ADV, se perceba toda a dinâmica que lhe confere a categoria de paisagem cultural, evolutiva e viva e que se reflete na organização do território em redes e parcerias, em polos dinamizadores da cultura, ensino, tecnologia e inovação, fatores determinantes para a valorização dos recursos endógenos tangíveis e intangíveis, para o incremento da competitividade e para a sua afirmação no plano nacional e internacional, como um destino sustentável.

Neste contexto, importa igualmente refletir sobre as mais-valias que o Sistema de Gestão e o processo de monitorização do ADV têm trazido ao desenvolvimento do território, enquanto plataforma privilegiada de articulação entre os órgãos de decisão e os agentes responsáveis pela transformação da paisagem.

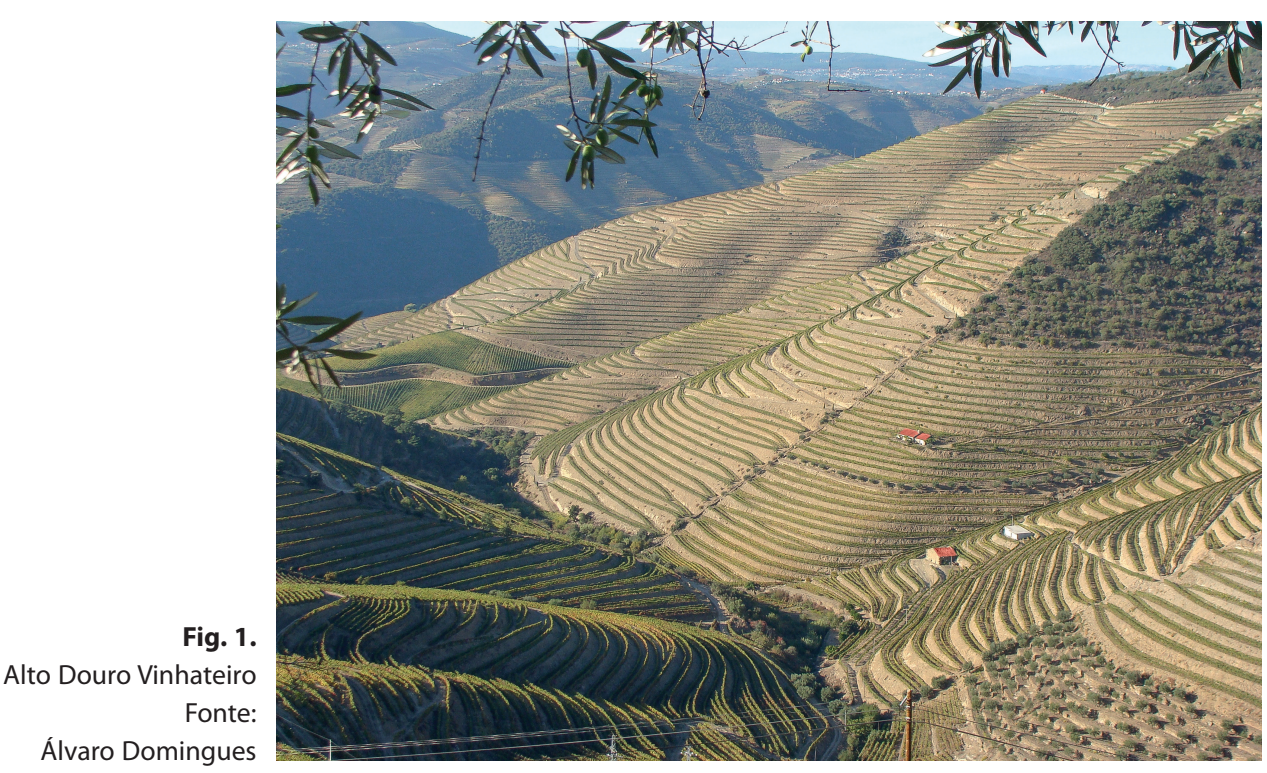




\section{CARACTERÍSTICAS E POTENCIALIDADES DO ALTO DOURO VINHATEIRO (ADV)}

O ADV é um dos 17 Sítios Nacionais classificados como Património da Humanidade, e ocupa uma área de 24600 hectares que correspondem à mancha mais representativa e bem preservada da Região Demarcada do Douro (RDD) com uma área total de 250000 hectares, ao longo da bacia hidrográfica do rio Douro, entre Barqueiros e Barca d'Alva, sendo esta coincidente com a sua Zona Especial de Proteção (ZEP).

Este contexto geográfico e socioeconómico encerra um legado singular, elementos únicos e identitários que levaram a UNESCO a reconhecer o seu Valor Universal Excecional consubstanciado numa paisagem cultural, construída ao longo de séculos pelo homem, resultante da conjugação de inúmeros fatores e da sua evolução ao longo dos tempos.

Na realidade, a perceção e conhecimento sobre os valores patrimoniais do ADV e a tomada de consciência sobre a relevância histórica e cultural da região vinhateira foram o ponto de partida para o processo de candidatura à UNESCO. Liderado pela Fundação Rei Afonso Henriques coube a uma equipa técnica pluridisciplinar estudar e delimitar a área a classificar, eleger os seus fatores distintivos que, no caso, se traduzem na antiguidade da Região Demarcada, nos terraços e no cruzamento de culturas e propor a sua classificação como Paisagem Cultural com base em três dos seis critérios possíveis:

- Critério (iii) - O ADV produz vinho desde há cerca de dois mil anos; a sua paisagem foi moldada pelas atividades humanas;

- Critério (iv) - As componentes da paisagem do ADV são representativas do completo leque de atividades associadas à produção vitivinícola - socalcos, quintas, aglomerados, capelas e vias de comunicação;

- Critério $(v)$ - A paisagem cultural do ADV constitui um excecional exemplo de uma região vitivinícola tradicional europeia, refletindo a evolução desta atividade humana através do tempo.

Com efeito, a antiguidade da cultura da vinha e as componentes únicas e identitárias representativas desta atividade presentes numa paisagem profundamente humanizada foram reconhecidas pela UNESCO e resultaram na inscrição do ADV na lista do Património Mundial da UNESCO, em 14 de dezembro de 2001, com a categoria de Paisagem Cultural Evolutiva e Viva.

Tal reconhecimento constituiu um novo marco na história da região, abrindo novas perspetivas para o seu reconhecimento e projeção à escala global.

Neste enquadramento, o ADV ocupa um posicionamento estratégico que the tem permitido tirar partido das mais-valias associadas à chancela UNESCO. Do 
ponto de vista geográfico, constitui-se como um corredor de pessoas e culturas entre os demais Sítios do Norte de Portugal e Espanha, nomeadamente o Centro Histórico do Porto, porta de entrada de milhares de pessoas e ponto de partida para o conhecimento mais aprofundado sobre a origem do vinho que lhe carrega o nome; o Centro Histórico de Guimarães pelo património histórico e arquitetónico que agrega enquanto «berço da nação»; como ligação ao país vizinho através dos Sítios Pré-históricos de Arte Rupestre do Vale do Rio Coa e Siega Verde, tirando partido dos programas científicos e técnicos promovidos pela Cátedra Geoparques Desenvolvimento Regional Sustentável e Estilos de Vida Saudáveis muito participados por estudantes e técnicos de diferentes partes do mundo, com quem o ADV tem vindo a cooperar; dando ainda a conhecer o sistema de fabrico do barro negro de Bisalhães e as tradições seculares escondidas no Geoparque Terras de Macedo.

Este enquadramento geográfico, aliado às atividades vitivinícolas, à qualidade dos vinhos do Douro e à abertura das quintas ao público (hoje com uma oferta diferenciada, que passou das tradicionais experiências sensoriais relacionadas com as provas de vinho e a participação de turistas e visitantes nas tarefas agrícolas, a ser complementada com alojamento turístico de elevadíssima qualidade e spas temáticos cada vez mais apreciados), tem potenciado o enoturismo na região, conforme revelam os últimos indicadores de crescimento do turismo na região - um cenário animador face ao elevado potencial de crescimento do setor, o que lhe confere um papel preponderante na sustentabilidade do território.

Recorde-se que, em 2008, o Douro foi o primeiro destino a receber uma avaliação do Sistema de Medição da Excelência dos Destinos, promovida pelo Centro Mundial de Excelência de Destinos, organização sem fins lucrativos reconhecida pela Organização Mundial de Turismo. A aplicação deste sistema de medição colocou a tónica na sustentabilidade do turismo como objetivo a longo prazo, preocupando-se igualmente em melhorar todos os níveis de experiência dos visitantes. Destacou a importância de trabalhar em parceria com organizações dos setores público e privado e outros parceiros no terreno, no sentido de se potenciar os pontos fortes, identificando os aspetos fundamentais a serem tratados e aperfeiçoados, visando fomentar a competitividade e a internacionalização deste destino. Com efeito, a partir deste estudo foi possível delinear estratégias para o desenvolvimento turístico da região e assim canalizar novos investimentos e projetos que permitissem melhorar as categorias onde o Douro obteve menor classificação, nomeadamente na formação profissional, otimizando as que, à partida, obtiveram a classificação de Excelente: Segurança, Saúde e Bem-estar, Alimentação e Bebidas, Transporte, Ambiente e Paisagem, Vinha e Cultura e Património.

Neste alinhamento, importa ainda referir a apetência da região para a implementação de percursos pedestres que contribuem, de um modo estruturante, para a 
proteção, a conservação e a valorização da paisagem, da biodiversidade, fomentando em paralelo o desenvolvimento de produtos turísticos de base local, assentes nos valores ambientais existentes e na promoção do exercício e da saúde dos seus habitantes e turistas. A esta rede de caminhos está associada uma rede de miradouros que abrange todo o território, cujos pontos privilegiados de observação da paisagem são muitas vezes coincidentes com locais de culto, como S. Leonardo de Galafura ou S. Salvador do Mundo, num convite ao descanso, à contemplação e interpretação da paisagem envolvente.

Também o rio Douro, enquanto via navegável, assume um papel determinante como meio de comunicação, como ponto de observação privilegiado para a fruição da paisagem, cada vez mais vocacionado para o turismo fluvial, explorado por operadores do setor, detentores de uma frota significativa de barcos e barcos-hotel.

Na perspetiva histórico-cultural, o ADV encerra uma herança coletiva profundamente associada à cultura da vinha e do vinho. No entanto, a ocupação do território remonta à ocupação pré-histórica, conforme documentam os vestígios arqueológicos do Vale do Coa. Depois, já no período romano, surgem os primeiros indícios da cultura da vinha, de acordo com os achados da estação arqueológica da Fonte do Milho e muitos outros. Foi igualmente marcante o legado da Ordem de Cister, que, a partir dos diferentes mosteiros instalados na região, incrementou a agricultura e a produção de vinho. Estes são alguns dos momentos-chave da história da região que hoje se refletem no seu mosaico paisagístico recortado por terraços e socalcos de vinha, muros de pedra posta de xisto e os demais elementos de arquitetura vernacular, alternância de culturas, com a presença de oliveiras, amendoeiras, pomares de citrinos e pequenas hortas, povoados, aldeias e vilas, as quintas do Douro, unidades de exploração agrária mais emblemáticas da vitivinicultura, edifícios e locais de culto, entre muitos outros.

É incontornável uma referência à filoxera que, no passado recente da região, foi um dos principais agentes de transformação da paisagem e da socioeconomia, causando enormes perdas aos vitivinicultores que se viram forçados a vender e abandonar as suas propriedades, deixando para trás um importante legado: os mortórios.

A este propósito, importa lembrar algumas personagens marcantes que povoam a história do Douro tais como Marquês de Pombal ou D. Antónia Ferreira, sem nunca esquecer que este património único é sobretudo o resultado de um percurso, muitas vezes tortuoso, de homens e mulheres anónimos que ajudaram a construir a paisagem, fazendo passar a cultura e a tradição de geração em geração.

O homem duriense continua a ser o grande motor de transformação e desenvolvimento do território e o detentor privilegiado de um conjunto de saberes e tradições, onde se enquadram as lides da cultura da vinha e da produção do vinho, a gastronomia típica, a animação das lagaradas, hoje recriadas como um produto 
turístico fundamental para a dinamização de pequenas aldeias, as técnicas construtivas com materiais tradicionais, patentes nos muros de xisto e demais património vernacular, as romarias, procissões e festas das vilas e aldeias, os cantares e músicas tradicionais, enfim um vasto património imaterial que tem sido guardado e transmitido ao longo de séculos.

No atual contexto impõe-se referir o papel das instituições de ensino superior, em particular da Universidade de Trás-os-Montes e Alto Douro (UTAD), não só na formação de quadros técnicos de excelência, designadamente na área do vinho, mas também na investigação e inovação tecnológica, em articulação estreita com o setor empresarial, sendo o Centro de Excelência da Vinha e do Vinho uma referência pelo trabalho que tem vindo a desenvolver nesta área.

\section{CONTRIBUTOS DO SISTEMA DE GESTÃO DO ADV PARA A VALORIZAÇÃO DO TERRITÓRIO}

Assim, referidas as principais características e potencialidades do Douro, numa perspetiva de sustentabilidade territorial, revisitados o processo de candidatura e os critérios de classificação, considerando que esta chancela trouxe responsabilidades acrescidas ao Estado português e à gestão do Sítio, quer no que toca à sua preservação e salvaguarda, quer na sua valorização, promoção e comunicação, estão reunidos os pressupostos para a implementação do Sistema de Gestão do ADV.

Recorde-se que à data da candidatura e face ao compromisso assumido pelo Estado foi elaborado o Plano Intermunicipal de Ordenamento do Território do Alto

Fig. 2.

Alto Douro Vinhateiro

Fonte:

Álvaro Domingues

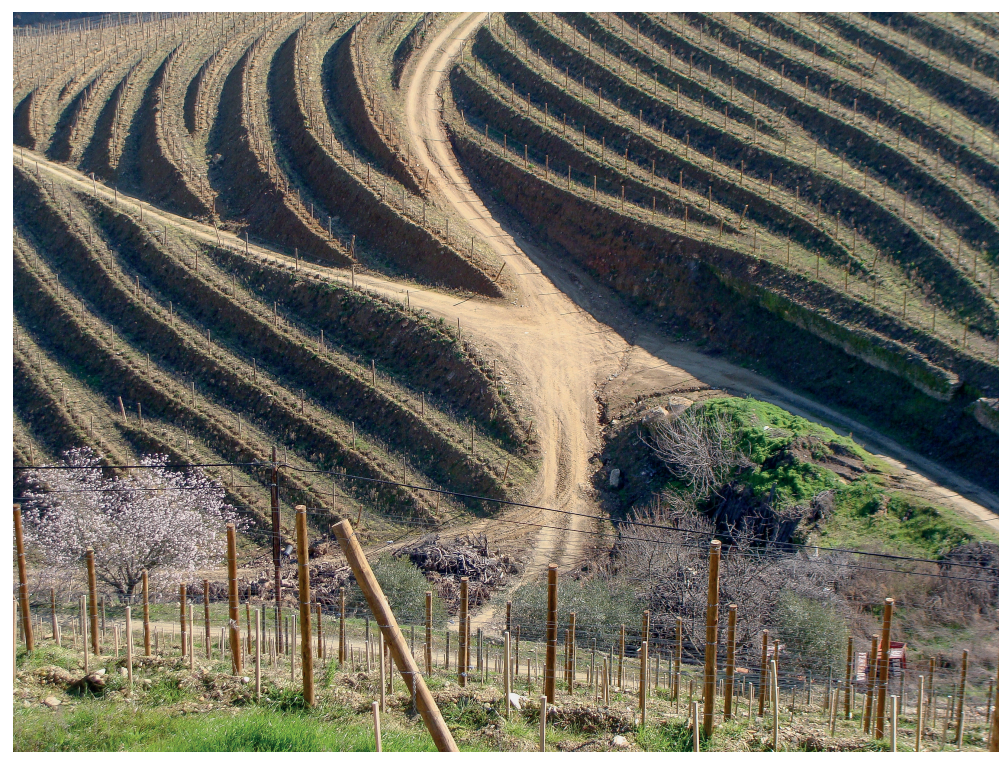


Douro Vinhateiro (PIOTADV), publicado pela Resolução do Conselho de Ministros n. ${ }^{o}$ 150/2003 de 22 de setembro ${ }^{1}$, documento que, para além da componente normativa relativa às práticas agrícolas e restantes intervenções em solo rural, estabelecia uma estratégia intermunicipal para a salvaguarda, proteção e valorização da paisagem cultural. Este plano foi subscrito pelos 13 municípios abrangidos pela área classificada e transposto para os Planos Diretores Municipais dos 19 concelhos da RDD.

Numa fase posterior, a publicação da Resolução do Conselho de Ministros $n .^{\circ} 4 / 2014^{2}$ de 10 de janeiro veio clarificar, junto da UNESCO, o Sistema de Gestão do ADV, determinando que a missão de proteger, conservar e valorizar, bem como divulgar e promover a «Paisagem Cultural Evolutiva e Viva do Alto Douro Vinhateiro», passaria a ser assegurada pela Comissão de Coordenação e Desenvolvimento Regional do Norte (CCDR-N), entidade que pela suas competências e historial estaria em condições de garantir uma gestão integrada do ADV atendendo à vasta e complexa área em questão. Visando a proximidade com o território e os seus agentes foi criado o Gabinete Técnico Missão Douro (GTMD), integrado e na dependência da Estrutura Sub-Regional de Vila Real (ESRVR), competindo-lhe prestar apoio técnico ao presidente da CCDR-N e Gestor do Bem, no âmbito da gestão e da monitorização. Este sistema de gestão contempla ainda a existência de dois órgãos consultivos: o Grupo Coordenador Permanente onde têm assento entidades públicas com responsabilidade na gestão do território como a Direção Regional de Agricultura e Pescas do Norte (DRAPN), a Direção Regional da Cultura (DRCN), o Turismo de Portugal, a Universidade de Trás-os-Montes e Alto Douro (UTAD), a Liga dos Amigos do Douro Património Mundial (LADPM), o Turismo do Porto e Norte e o Conselho Consultivo que dá voz às cerca de 50 entidades públicas e privadas, representativas dos diferentes setores de atividade, que têm permitido por um lado articular opções de gestão entre pares, por outro ter uma perceção atualizada sobre as dinâmicas da região.

Por outro lado, o modelo de monitorização que, desde essa data, se tem vindo a implementar e que faz parte integrante do Sistema de Gestão, foi desenhado tendo em conta as especificidades da região e assenta em indicadores específicos para cada uma das quatro componentes estabelecidas: monitorização dos processos da tutela, das atividades económicas, da comunicação e da paisagem - abordagem centrada na análise da estrutura, composição e funcionamento da paisagem em diferentes escalas. A componente paisagem é a que tem colocado maiores desafios, tendo sido definido um minucioso conjunto de indicadores que inclui por exemplo, a área de vinha reconvertida, os socalcos, os patamares, a vinha ao alto, a vinha sem armação,

\footnotetext{
${ }^{1}$ PORTUGAL. Presidência do Conselho de Ministros, 2003: 6144-6159.

${ }^{2}$ PORTUGAL. Presidência do Conselho de Ministros, 2014: 92-95.
} 
a área de olival, a área de amendoal, a área ocupada por outras culturas, a existência de bordaduras, os pomares de citrinos, os mortórios, a reconstrução e construção de muros tradicionais do Douro, as manchas de matos, matas, povoamentos florestais e galerias ripícolas, a preservação e valorização do edificado, entre outros elementos patrimoniais.

Este trabalho é sustentado por uma base de dados geográficos, onde os processos em gestão são georreferenciados, permitindo mapear as alterações à ocupação do solo, informação complementada e validada através de visitas de campo regulares. Por outro lado, a análise comparativa desta informação, conjugada com os dados de natureza estatística, obtidos juntos das entidades parceiras e INE, resulta numa visão integrada sobre as dinâmicas do território. A sistematização destas alterações tem sido imprescindível na avaliação da sua compatibilidade com os critérios de classificação do ADV, bem como na elaboração de documentação de reporte.

Não obstante a preocupação de alargar a monitorização a toda a área da RDD, foram definidas áreas de amostragem prioritárias que correspondem às dez paisagens de referência com uma área aproximada de 500 hectares cada.

A monitorização é um processo contínuo que procura incorporar as alterações normativas que acompanham, por exemplo, os desígnios do ordenamento do território, as necessidades do setor produtivo e as melhorias que, decorrentes da autoavaliação da gestão, vão sendo implementadas.

Refira-se, a propósito, que, ao longo de décadas, as características do solo e os declives foram os fatores que mais condicionaram a sistematização e armação do terreno das vinhas, hoje, os efeitos decorrentes das alterações climáticas, já com alguma expressão, têm mobilizado as entidades com responsabilidade de gestão, nomeadamente os municípios, os vitivinicultores e suas associações para realizarem estudos e projetos que permitam definir estratégias e planos de combate e minimização de tais efeitos, para que, de alguma forma, se vá adaptando a produção vitivinícola às novas condições, resultantes do agravamento da escassez de água, do aumento das temperaturas e de fenómenos extremos, aspetos a ter em conta no processo de gestão e monitorização do ADV.

\section{FORMAÇÃO, PARTICIPAÇÃO, REDES, ROTAS E PARCERIAS}

Neste contexto, a Missão Douro e o seu Gabinete Técnico têm privilegiado a cooperação, o trabalho em rede e o estabelecimento de parcerias como formas de potenciar o desenvolvimento integrado, coeso e sustentável da região, assumindo-se como uma plataforma colaborativa e de entendimento entre os diferentes interlocutores, à escala regional, nacional e internacional.

As ações de sensibilização, a partilha de conhecimento e experiências, o trabalho direto com a comunidade escolar e as populações locais são um veículo fundamental 


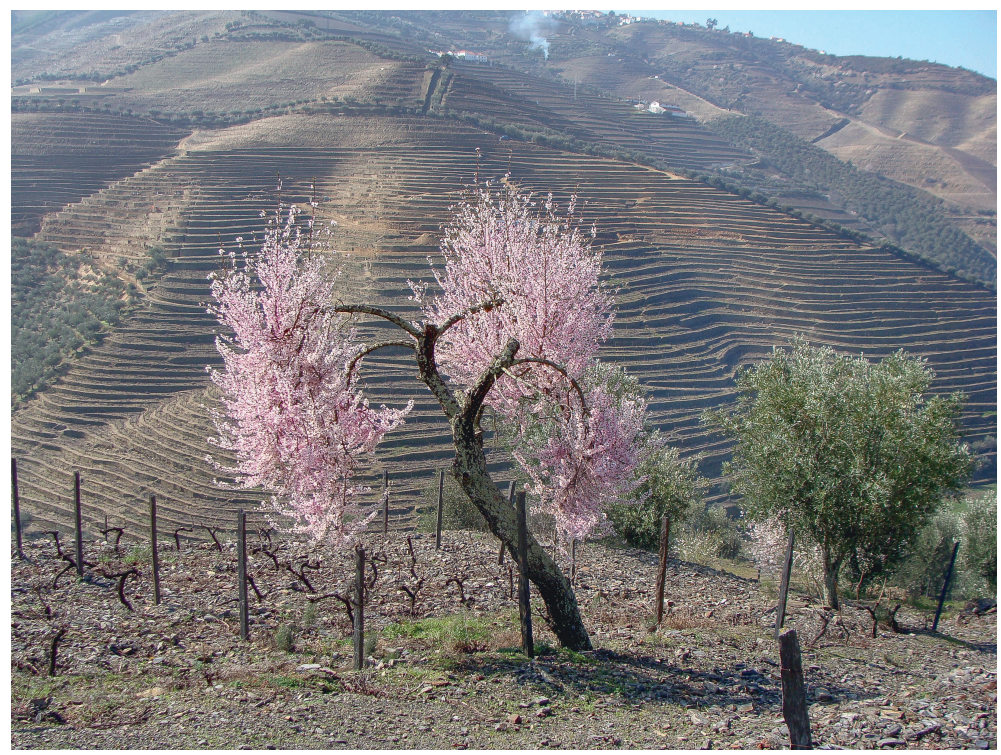

Fig. 3.

Alto Douro Vinhateiro

Fonte:

Álvaro Domingues

para a disseminação do Valor Universal e Excecional do ADV, da importância cultural e económica da classificação UNESCO, da apropriação do conceito Património e da consolidação da identidade coletiva do Sítio.

Ao nível local e regional destacam-se as ações de sensibilização e formação de técnicos de associações do setor vitivinícola e dos próprios técnicos da Missão Douro, bem como as ações de sensibilização e formação de vitivinicultores no terreno, não só para importância de se adotarem as melhores práticas agrícolas e ambientais nas intervenções levadas a cabo, mas também para preservação do património, nomeadamente o património vernacular como forma de manter a integridade e qualidade da paisagem.

O envolvimento da comunidade escolar tem sido outra das apostas da Missão Douro e tem passado pela participação ativa na formação de professores, em parceria com a LADPM, promoção de concursos escolares, o acompanhamento de visitas de estudo e comunicações sobre o ADV em contexto de aulas, em parceria com a UTAD.

De igual forma se têm apoiado projetos e ações envolvendo as comunidades locais, tendo-se dado enfoque à iniciativa Somos Douro, um festival multidisciplinar, vocacionado para a camada jovem da região, descentralizado pelos 19 municípios da Comunidade Intermunicipal do Douro (CIM Douro), promovido em parceria pela Missão Douro, LADPM e CIM Douro, que teve como comissária Anabela Mota Ribeiro.

Este festival incluiu a realização de oficinas temáticas, sobre literatura, a partir de autores locais, fotografia, escrita, ilustração, espetáculos diversos, roteiros, fóruns e uma sondagem junto das camadas mais jovens da população no sentido de se iden- 
tificarem os principais constrangimentos e apelos à sua permanência no território, cujos resultados foram publicamente apresentados, com testemunhos na primeira pessoa por jovens da região.

Em paralelo, e no âmbito das suas competências, a Missão Douro tem dado o seu contributo na consolidação de algumas redes, estruturantes na organização da oferta cultural e turística da região como é o caso da Rede das Aldeias Vinhateiras do Douro, um projeto cofinanciado por fundos comunitários criado com o objetivo de criar uma dinâmica de regeneração e valorização das aldeias através da revitalização socioeconómica, da fixação de população e do reforço da promoção turística. Incluem-se nesta rede povoados de reconhecido valor histórico, arquitetónico e ambiental e que expressam a realidade duriense, lendas tradições e gastronomia potenciadas por um programa de animação cultural. Esta rede compreende as aldeias de Barcos, Favaios, Provesende, Salzedas, Trevões e Ucanha ligadas pela cultura da vinha e do vinho.

A MUD - Rede de Museus do Douro é outro exemplo paradigmático enquanto plataforma de cooperação e comunicação entre diferentes instituições museológicas e culturais, públicas e privadas, da RDD e foi implementada com o objetivo de agregar os seus membros num projeto cultural comum, vocacionado para o desenvolvimento integrado do território. Salienta-se o espírito de entreajuda técnica e o recurso às novas tecnologias de informação para divulgação de projetos e atividades desenvolvidas no seio da rede. Este projeto foi impulsionado a partir do Museu do Douro, um museu de território, polivalente e polinuclear, vocacionado para reunir, conservar, identificar e divulgar o vastíssimo património museológico e documental disperso pela região, devendo constituir um instrumento ao serviço do desenvolvimento sociocultural da região.

Centrada no vale do rio Varosa, e promovida pela DRCN, a Rede de Monumentos do Vale do Varosa assenta na criação de uma rede de monumentos abertos, de forma integrada, à fruição do público, tendo como núcleo principal, os mosteiros cistercienses de São João de Tarouca e de Santa Maria de Salzedas e o convento franciscano de Santo António de Ferreirim. Do conjunto de atividades que este projeto proporciona, como os jantares monásticos, o Horto Monástico do Mosteiro de São João de Tarouca é um projeto que pretende devolver a paisagem do século XVIII na cerca deste mosteiro cisterciense, recriando o espaço agrícola outrora cultivado pelos monges. Neste contexto, a seleção das espécies a cultivar é criteriosamente observada e tem por base a investigação histórica.

No contexto nacional destacam-se as iniciativas conjuntas de Rede do Património Mundial de Portugal que têm permitido a promoção e comunicação integrada dos 17 Sítios classificados, bem como as comunicações e intervenções em congressos, seminários, workshops e outros eventos, fóruns privilegiados para dar a conhecer o património do ADV. 


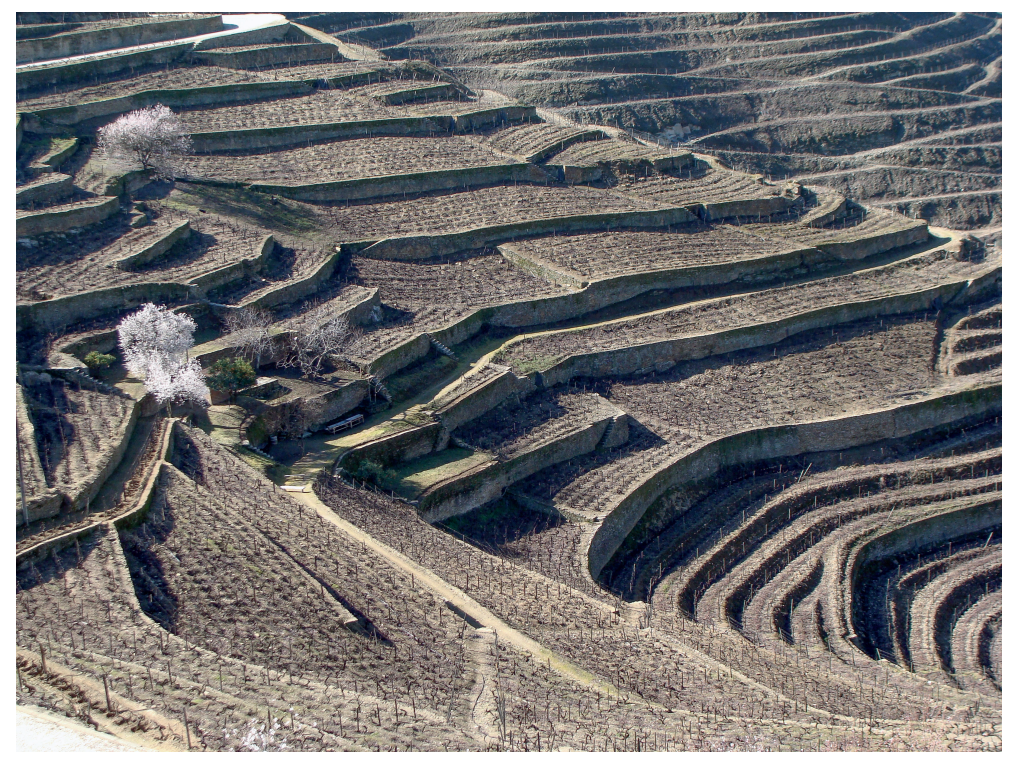

Fig. 4.

Alto Douro Vinhateiro

Fonte:

Álvaro Domingues

A nível internacional a Missão Douro tem participado, com regularidade, nos encontros ibéricos e europeus de Gestores de Património Mundial, sede fundamental para a troca de conhecimento e de boas práticas no âmbito da gestão, bem como em programas a candidaturas transfronteiriças no contexto da cooperação com a Rede VITOUR Landscape ou a Rota do Património Mundial Douro/Duero, por exemplo.

\section{CONCLUSÃO}

Em suma, uma área classificada como Património Mundial, com as características e singularidades do ADV, constitui um grande desafio ao nível da gestão, exigindo o envolvimento e a cooperação de todos os agentes públicos e privados que interagem no território.

O passado recente desta região tem demonstrado que o trabalho em rede e o estabelecimento de parcerias são uma opção estratégica para o desenvolvimento sustentável, para incremento da competitividade e da afirmação do território como um destino de eleição, não só do ponto de vista turístico, mas como terreno fértil à inovação, à criação de oportunidades de negócio e emprego qualificado e, por conseguinte, à fixação de população jovem, capaz de assegurar a continuidade deste legado.

Com efeito, o ADV apresenta uma localização geográfica estratégica e privilegiada, uma riqueza natural, cultural e patrimonial excecional e uma elevada notoriedade associada à chancela UNESCO, reunindo todas as condições para permanecer na senda da sustentabilidade, enfrentando, com resiliência, os constrangimentos que decorrem, 
sobretudo, do desequilíbrio sociodemográfico do país, do aumento da concorrência e competitividade de destinos turísticos similares e ainda das alterações climáticas.

Assim, para além das medidas de preservação e salvaguarda da paisagem, importa uma aposta crescente na comunicação integrada, no marketing territorial, na formação e qualificação dos recursos humanos, na investigação e na inovação, como formas de se alcançar a qualidade e a diferenciação que se pretende associadas ao Património Mundial.

Conclui-se com um agradecimento especial a todos os envolvidos na organização do III Workshop Douro e Pico: Paisagens Culturais Vinhateiras, Património da Humanidade, e uma palavra de reconhecimento pela relevância e temas abordados, fundamentais para a consolidação do conhecimento e das boas práticas de gestão destes dois Sítios.

\title{
BIBLIOGRAFIA
}

AGUIAR, Fernando Bianchi de et al., coord. (2002). Plano Intermunicipal de Ordenamento do Território do Alto Douro Vinhateiro. Vila Real: UTAD.

ANDRESEN, T.; REBELO, J. (2013). Avaliação do Estado de Conservação do Bem Alto Douro Vinhateiro - Paisagem Cultural Evolutiva Viva. Porto: CCDR-N/EMD; CIBIO UP/UTAD. Vol. 1: Relatório de Avaliação.

FAZENDA, Nuno (2015). Turismo 2020 - Plano de Ação para o Desenvolvimento do Turismo em Portugal. Guimarães: Turismo de Portugal, I.P.

FUNDAÇÃO REI AFONSO HENRIQUES (2000). Candidatura do Alto Douro Vinhateiro a Património Mundial. Porto: Marca-Artes Gráficas.

HAYWOOD, Michael (2008). Vale do Douro, Norte de Portugal - Relatório Executivo do Sistema de Medição de Excelência dos Destinos. Porto: CCDR-N.

PORTUGAL. Presidência do Conselho de Ministros (2003). Resolução do Conselho de Ministros n. ${ }^{\circ}$ 150/2003. «Diário da República Série I-B». 219 (2003-09-22) 6144-6159.

PORTUGAL. Presidência do Conselho de Ministros (2014). Resolução do Conselho de Ministros n. ${ }^{\circ}$ 4/2004. «Diário da República Série I». 7 (2014-01-10) 92-95.

SENRA, José Nuno Torres (2014). O turismo fluvial como vetor de desenvolvimento turístico do Alto Douro Vinhateiro Património da Humanidade. Braga: Universidade do Minho. Tese de mestrado. Disponível em $<$ http://repositorium.sdum.uminho.pt $>$.

\section{Fontes complementares}

\author{
$<$ http://www.ccdr-n.pt/> \\ $<$ https://en.unesco.org/> \\ $<$ https://www.apambiente.pt/> \\ $<$ https://www.unescoportugal.mne.pt/pt/a-cnu> \\ $<$ http://www.ccdrn.pt/somosdouro/home > \\ $<$ https://anabelamotaribeiro.pt/festival-somos-douro-1-a-17-junho-19-247118> \\ $<$ https://www.ivdp.pt/> \\ $<$ https://www.rpmp.pt/> \\ $<$ https://www.rpmp.pt/repositorio >
}




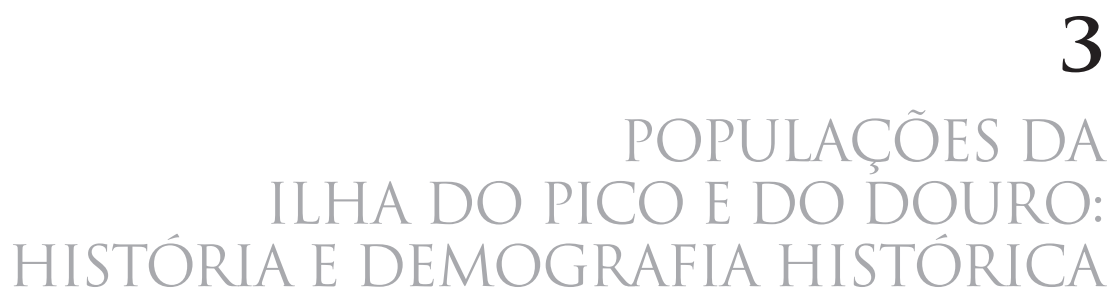





\title{
ESPAÇOS ARDIDOS E O ESPANTOSO COMPORTAMENTO DEMOGRÁFICO DA GENTE QUE LÁ MEDROU (SÉCULOS XVII A XX)
}

\author{
MARIA NORBERTA AMORIM*
}

Resumo: Através de Mapas de Proprietários, publicados pela Imprensa Nacional, na década de 1880, para utilização nas Repartições de Finanças, referidos a cada freguesia e baseados nas matrizes prediais, comparámos os rendimentos coletáveis nas quatro ilhas do ex-distrito da Horta. Calculámos o rendimento coletável por habitante e freguesia, observando como freguesia de gente mais pobre a de Santa Luzia, no espaço ardido do Pico. Com população sensivelmente idêntica, a freguesia mais rica era, nas Flores, a de Ponta Delgada. Desenvolvemos análises comparativas de comportamentos demográficos entre essas freguesias nos séculos XVII e XX, com incidência nos séculos XVIII e XIX. Num quadro de fecundidade próxima da natural, encontrámos evolução populacional paralela, com diferenças em nupcialidade e mortalidade. Nas gerações nascidas entre finais do século XVIII e primeiras décadas do XIX a esperança de vida dos naturais da freguesia mais pobre era de mais 10 anos do que os da freguesia mais rica.

Palavras-chave: Evolução demográfica (séculos XVIII-XIX); Comportamentos demográficos comparados; Açores; Ilha do Pico; Ilha das Flores.

\begin{abstract}
Using Maps of Owners, published by the National Press, in the 1880s, for use in the Finance Departments referred to each parish and based on the land matrices, we compared the taxable income on the four islands of the former district of Horta. We calculated the taxable income per inhabitant and parish, observing that the parish of the poorest people was that of Santa Luzia, in the burnt space of Pico. With a substantially identical population, the richest parish was, in Flores, that of Ponta Delgada. We developed comparative analyzes of demographic behaviors between these parishes in the 17th and 20th centuries, with an incidence in the 18th and 19th centuries. In a close-to-natural fertility situation, we found a parallel population evolution, with differences in nuptiality and mortality. In the generations born between the end of the 18th century and the first decades of the 19th, the life expectancy of the natives of the poorest parish was 10 years longer than those of the richest parish.
\end{abstract}

Keywords: Demographic evolution (19th-20th centuries); Compared demographic behaviors; Azores; Pico island; Flores island.

\section{INTRODUÇÃO}

Apesar da ilha do Pico ser a ilha açoriana de formação geológica mais recente, com solo pouco propício à cultura dos cereais, particularmente na sua metade ocidental, ultrapassada a crise frumentária de meados do século XVIII que condicionou uma

\footnotetext{
* CITCEM/FLUP; CECS/U. Minho. Email: mnsbamorim@gmail.com.
} 
forte mortalidade ${ }^{1}$ e a deslocação de casais para povoar as fronteiras brasileiras, a carência cerealífera não impediu que até aos anos 40 do século seguinte, a população do espaço ardido, que vai da freguesia de São Mateus a Santa Luzia, como em toda a ilha, atingisse impressionantes níveis de crescimento. A vinha, as figueiras e outras árvores de fruto encontravam aí condições muito favoráveis de produtividade e proprietários e comerciantes, bem posicionados, em sua maioria da vizinha ilha do Faial, exploravam as vinhas e lançavam o vinho do Pico nos mercados internacionais.

Nessa década de 40 do século XIX entrou-se numa fase de rutura entre a população e os recursos alimentares disponíveis, o que se agravou com a crise das vinhas no início da década seguinte. Tal obrigou a uma emigração massiva, com queda acentuada e irreversível nos volumes populacionais, como o demonstram as monografias sobre freguesias da área que tenho vindo a desenvolver ${ }^{2}$.

Para o período de maior pujança demográfica não dispomos de fontes que nos permitam uma perspetiva da inserção das diferentes comunidades no seu espaço residencial e produtivo, o que vai acontecer para meados da década de 1880, com a elaboração das matrizes prediais. Passamos então a poder valorizar mais a resiliência destas comunidades de solo pobre, comparativamente a outras comunidades da mesma ilha e, principalmente, a outras comunidades das outras ilhas que formavam então o distrito da Horta.

Com base nos registos paroquiais de batizados, casamentos e óbitos (que se vão iniciando, neste caso, ao longo do século XVII e que foram trabalhados até, pelo menos, o início do século XX), está já ao nosso alcance uma aproximação aos comportamentos demográficos na longa duração das comunidades das ilhas do Pico, Faial e Corvo e das freguesias de Ponta Delgada e Lajes, das Flores, estando em curso a reconstituição das restantes freguesias desta última ilha.

Com base nessas fontes básicas, as matrizes prediais de meados da década de 1880, ou os mapas de proprietários correspondentes, e as bases de dados demográfico-genealógicas de que dispomos ${ }^{3}$, podemos avançar para interessantes análises comparativas sobre comunidades desse mesmo espaço administrativo, com recursos naturais bastante diversificados e comportamentos demográficos distintos, em que a pobreza não se correlaciona necessariamente com a esperança de vida.

Assim, iremos primeiro tentar uma aproximação à riqueza relativa nas quatro ilhas e depois contrastar comportamentos demográficos de duas comunidades de ilhas afastadas, diferentemente bafejadas por essa riqueza.

\footnotetext{
${ }^{1}$ AMORIM, 2020.

${ }^{2}$ AMORIM, 1992, 2008, 2011, 2016.

${ }^{3}$ Veja-se $<$ www.csarmento.uminho.pt $>$.
} 


\section{ESPAÇOS E RECURSOS}

As matrizes prediais de meados da década de 1880 não chegaram até nós em todas as ilhas. Havendo sido substituídas por outro levantamento da propriedade datado de 1937, foram em geral eliminadas, excetuando-se o caso da ilha do Pico, onde, no que respeita à propriedade rústica, continuaram a ser utilizadas nas Repartições de Finanças até épocas recentes.

Para oito das freguesias do Pico já explorámos essas matrizes prediais, como fontes básicas para as monografias a que nos propusemos (Lajes do Pico, São João, a grande São Mateus, desdobrada depois em São Mateus e São Caetano, Candelária, Santa Luzia, Prainha e Santo Amaro). Aí são identificadas todas as propriedades rústicas pelo nome do proprietário, pela localização em zonas geográficas com os seus nomes específicos, pela dimensão, quase sempre em alqueires ou unidades inferiores, as braças, pelo tipo de produção, eventualmente pelo nível de produtividade e pelo rendimento coletável que lhe foi atribuído. No caso da propriedade urbana, além do nome do proprietário e do rendimento coletável, há quase sempre referência ao tipo de casa, térrea ou de um ou mais pisos, telhada ou coberta de palha, com cozinha separada ou não.

Para a monografia do Corvo, explorámos as matrizes prediais relativas a 1937, tendencialmente com o mesmo tipo de informação ${ }^{4}$.

Apesar das matrizes prediais de meados da década de 1880 só chegarem a nós, sistematicamente, para a ilha do Pico, foi publicado pela Imprensa Nacional um Mappa organisado em conformidade com o artigo $108 .^{\circ}$ do regulamento de 25 de agosto de 1881, contendo, por ordem alphabetica, os nomes e moradas dos contribuintes inscriptos na matriz predial d'esta freguezia, e o rendimento collectavel total dos predios que cada um n'ella possue (Fig. 1). Por gentileza do Sr. Manuel Machado Oliveira, tivemos acesso a uma encadernação desses mapas a cobrir todas as freguesias do ex-distrito, da qual a Biblioteca Pública e Arquivo Regional João José da Graça, da cidade da Horta, possui hoje uma cópia.

Os mapas referidos, para cada uma das freguesias das quatro ilhas, no fim da enumeração dos proprietários, das respetivas residências, da enumeração dos artigos matriciais que lhes correspondem e do rendimento coletável global, encerram com a indicação do rendimento coletável por freguesia e, quase sempre, o número total de artigos matriciais, além da data e identificação do magistrado responsável pelo trabalho.

${ }^{4}$ AMORIM, 2018. 
Fig. 1.

Primeira folha do Mapa de Proprietários relativo a São João do Pico Fonte: Biblioteca Pública e Arquivo Regional João José da Graça

Districto da Horta Concelho das Lages do Pico Freguezia de S. João statrix prodinl n.* 1

Happa organisado ma conformidade do artigo 108. do regulamento de 25 de agosto de 1881 , contendo. por ordem alphabetica. os nomes $\mathrm{c}$ moradas dos contribuintes inseriptos na matriz pre-

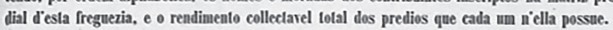

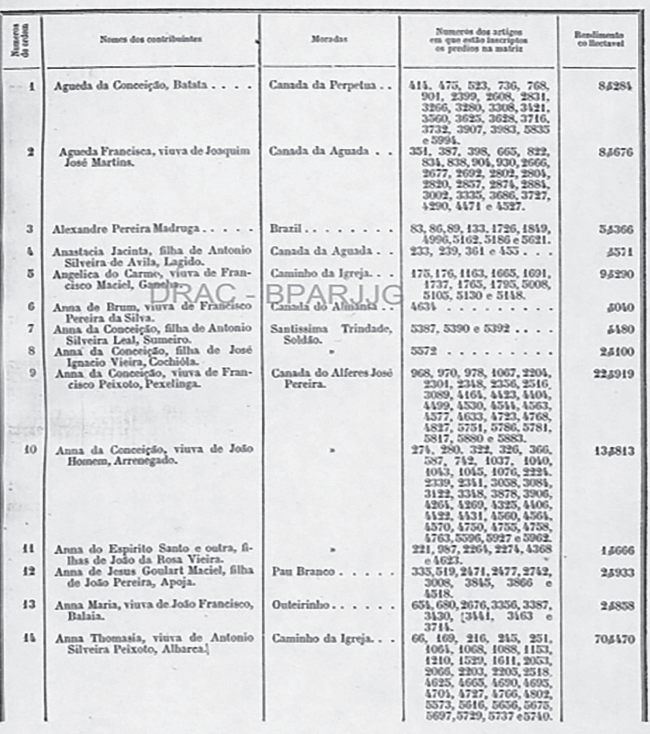

Usando os somatórios dos rendimentos coletáveis de cada freguesia e os somatórios dos números matriciais (recorrendo, nos casos omissos, às listagens de propriedades para encontrar nelas o número matricial mais elevado), podemos calcular o valor coletável médio por artigo matricial, caso a caso.

Embora se trate de um indicador grosseiro, que pode apontar para a dimensão da propriedade, mas que inclui também a diferente valorização dessa propriedade, pode fornecer-nos algumas pistas de partida.

Tabela 1. R.C./artigo matricial/ilhas (réis)

\begin{tabular}{l|c|c|c}
\hline \multicolumn{1}{c|}{ Ilha } & R.C. & N. de artigos & R.C./artigo \\
\hline Pico & $63503 \$ 470$ & 122004 & $\$ 521$ \\
\hline Faial & $144419 \$ 274$ & 52495 & $2 \$ 751$ \\
\hline Flores & $31778 \$ 180$ & 22719 & $1 \$ 399$ \\
\hline Corvo & $3906 \$ 991$ & 5670 & $\$ 689$ \\
\hline
\end{tabular}

Fonte: Elaboração da autora 
Como se verifica, foi na ilha do Pico onde o rendimento por artigo matricial se apresentou mais reduzido, seguindo-se o Corvo e, a maior distância, as Flores, sobressaindo do conjunto a ilha do Faial. O menor rendimento por artigo matricial no Pico e no Corvo poderá apontar para parcelas de propriedade rústica de dimensão reduzida, sendo de esperar uma maior dimensão dessas parcelas nas Flores e no Faial, embora haja a considerar a maior valorização da propriedade urbana na cidade da Horta. Pelo Mapa de Proprietários não podemos distinguir a propriedade urbana da rústica.

A distribuição por freguesias permite constatar sobre essa valorização da propriedade na cidade da Horta, particularmente no caso da Matriz com toda a propriedade tendencialmente urbana, das três vilas do Pico e das duas vilas das Flores, embora, no caso das vilas, as zonas claramente urbanas sejam de dimensão reduzida. Podemos ainda observar a diferente situação nas freguesias rurais.

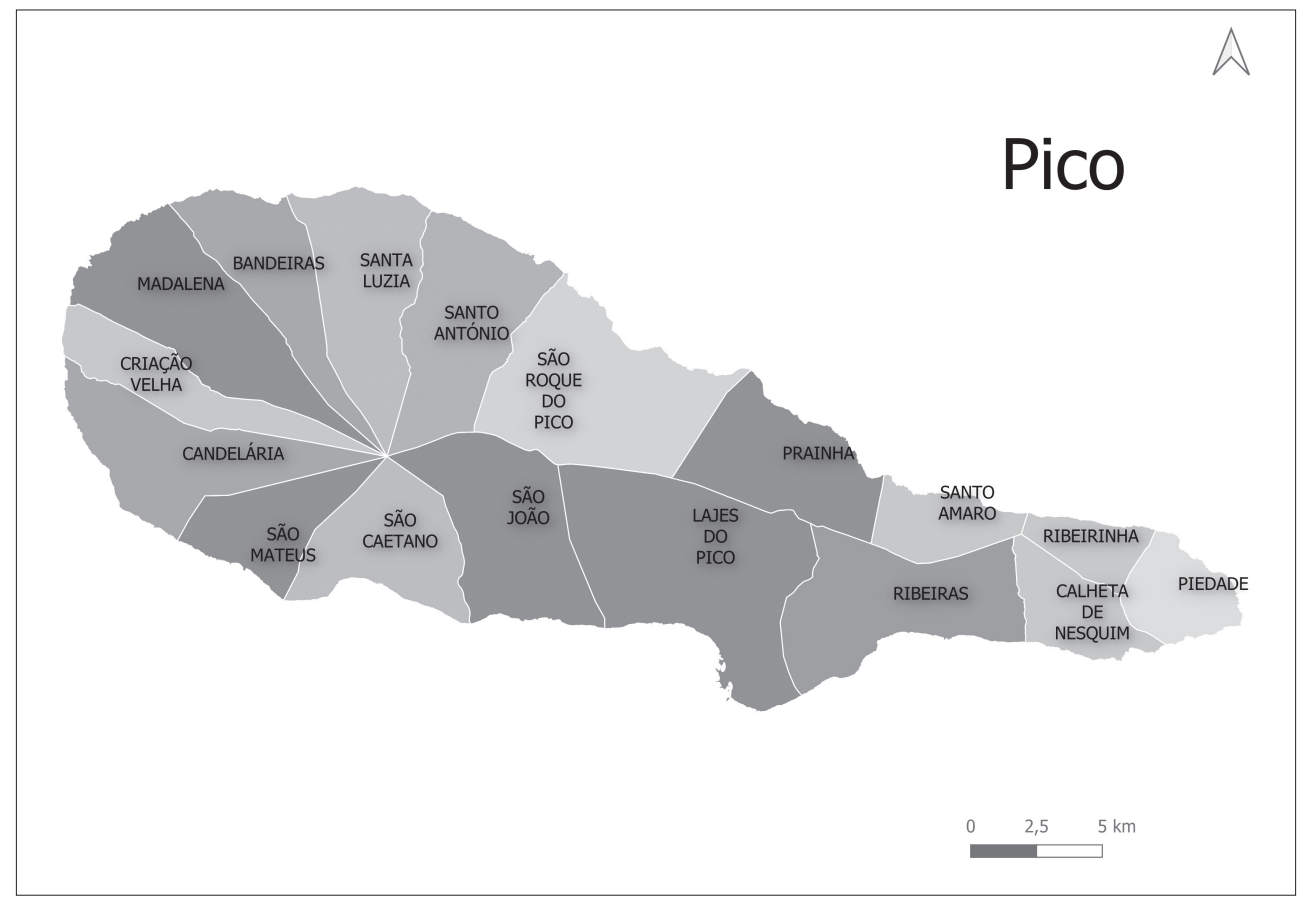

Mapa 1. Pico

Fonte: CAOP2013/Casa de Sarmento - CEP 
Tabela 2. R.C./artigo matricial/Pico (réis)

\begin{tabular}{|c|c|c|c|}
\hline Freguesias & R.C. & N. ${ }^{\circ}$ de artigos & R.C./artigo \\
\hline Bandeiras & $2221 \$ 128$ & 3909 & $\$ 568$ \\
\hline Madalena & $9536 \$ 014$ & 8265 & $1 \$ 154$ \\
\hline Criação Velha & $1799 \$ 983$ & 6134 & $\$ 293$ \\
\hline Candelária & $2760 \$ 775$ & 11028 & $\$ 250$ \\
\hline São Mateus & $5174 \$ 120$ & 17212 & $\$ 301$ \\
\hline São João & $2883 \$ 272$ & 5995 & $\$ 481$ \\
\hline Lajes do Pico & $8315 \$ 915$ & 8272 & $1 \$ 005$ \\
\hline Ribeiras & $4777 \$ 650$ & 8354 & $\$ 572$ \\
\hline Calheta de Nesquim & $3859 \$ 239$ & 5079 & $\$ 760$ \\
\hline Piedade & $6894 \$ 925$ & 15025 & $\$ 459$ \\
\hline Santo Amaro & $2051 \$ 715$ & 3889 & $\$ 528$ \\
\hline Prainha & $3719 \$ 512$ & 9478 & $\$ 392$ \\
\hline São Roque do Pico & $4011 \$ 291$ & 6211 & $\$ 646$ \\
\hline Santo António & $3264 \$ 222$ & 7532 & $\$ 433$ \\
\hline Santa Luzia & $2233 \$ 708$ & 5621 & $\$ 397$ \\
\hline
\end{tabular}

Fonte: Elaboração da autora

Gráfico 1.

Freguesias do Pico R.C./Artigo Fonte: Elaboração da autora
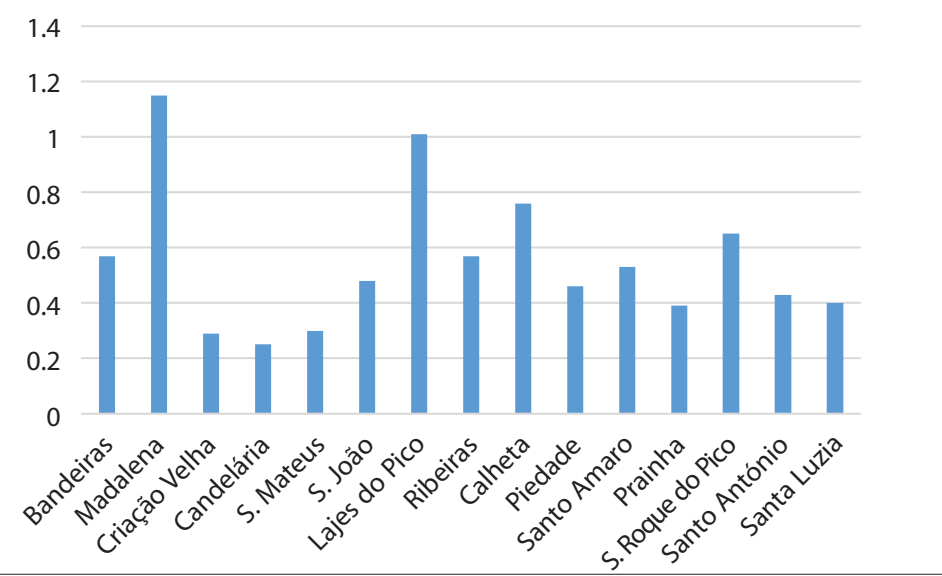

Como se verifica, é nas freguesias da Madalena, Criação Velha, Candelária e São Mateus que o rendimento coletável por artigo matricial se coloca em nível mais baixo, no contexto de toda a ilha, à volta dos $\$ 300$ réis, ou menos, por artigo. No entanto, no mesmo concelho, as freguesias de Bandeiras e Madalena distinguem-se, ao que não será estranho a propriedade rústica de maior dimensão usufruída por proprietários do Faial, a que poderá acrescer, no caso da Madalena, a maior valo- 
rização da propriedade urbana. Essa valorização da propriedade urbana distingue também a vila das Lajes, sendo Madalena e Lajes as únicas freguesias do Pico em que se atingem os $1 \$ 000$ réis de rendimento coletável por artigo, o que não chega a acontecer na vila de São Roque do Pico.

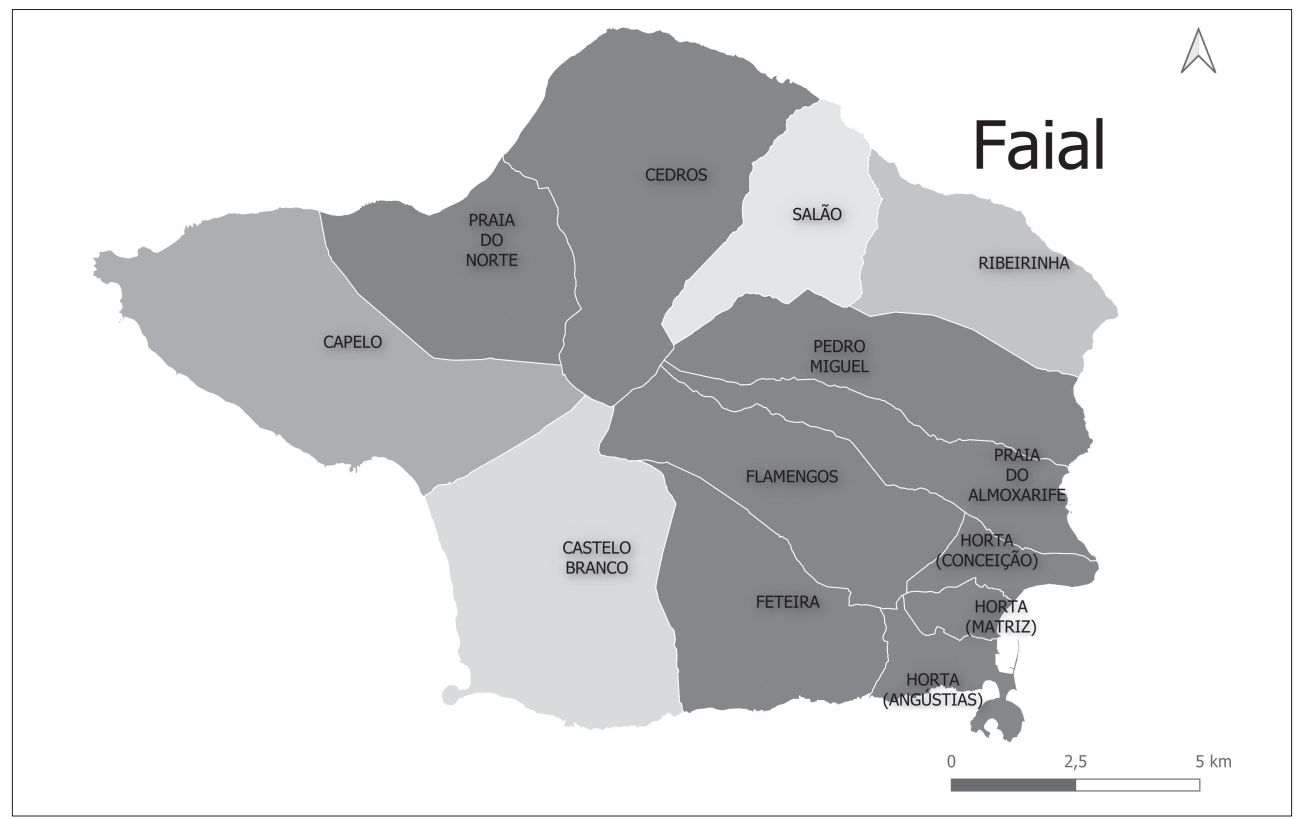

Mapa 2. Faial

Fonte: CAOP2013/Casa de Sarmento - CEP

Tabela 3. R.C./artigo matricial/Faial (réis)

\begin{tabular}{l|c|c|c}
\hline \multicolumn{1}{c|}{ Freguesias } & R.C. & N. ${ }^{\circ}$ de artigos & R.C./artigo \\
\hline Matriz & $21561 \$ 710$ & 778 & $4 \$ 484$ \\
\hline Conceição & $9548 \$ 420$ & 638 & $5 \$ 746$ \\
\hline Angústias & $17102 \$ 150$ & 881 & $3 \$ 195$ \\
\hline Flamengos & $9515 \$ 965$ & 3281 & $\$ 356$ \\
\hline Feteira & $18852 \$ 696$ & 4415 & $1 \$ 446$ \\
\hline Castelo Branco & $14105 \$ 732$ & 8554 & $1 \$ 207$ \\
\hline Capelo & $3049 \$ 085$ & 7140 & $1 \$ 946$ \\
\hline Praia do Norte & $1734 \$ 639$ & 11053 & $3 \$ 908$ \\
\hline Cedros & $15980 \$ 306$ & 4944 & $5 \$ 304$ \\
\hline Salão & $5964 \$ 950$ & 4573 & $4 \$ 484$ \\
\hline Ribeirinha & $8898 \$ 065$ & 2668 & $5 \$ 746$ \\
\hline Pedro Miguel & $10425 \$ 585$ & 1448 & $3 \$ 195$ \\
\hline Praia do Almoxarife & $7679 \$ 971$ & & \\
\hline
\end{tabular}

Fonte: Elaboração da autora 
Gráfico 2.

R.C./artigo matricial/

Faial (réis)

Fonte:

Elaboração da autora

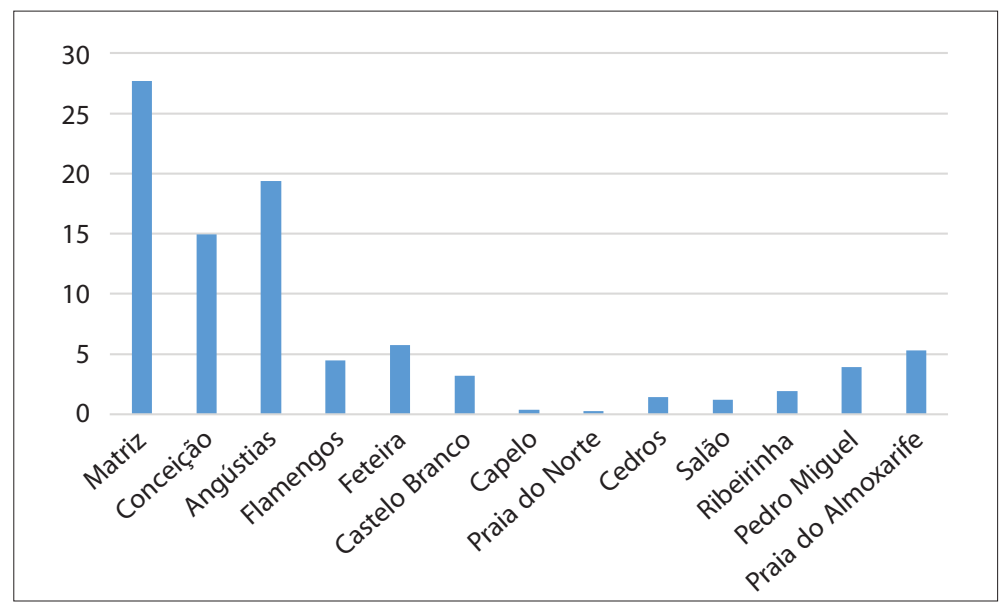

No Faial, são apenas as freguesias fustigadas por vulcões recentes (1672), Capelo e Praia do Norte, onde o rendimento coletável por artigo baixa de $\$ 400$ réis, colocando-se em todas as outras freguesias acima de $1 \$ 000$ réis, sobressaindo a cidade, em que se salienta a freguesia da Matriz, com propriedade quase exclusivamente urbana, a ultrapassar os $27 \$ 000$ réis por artigo matricial.

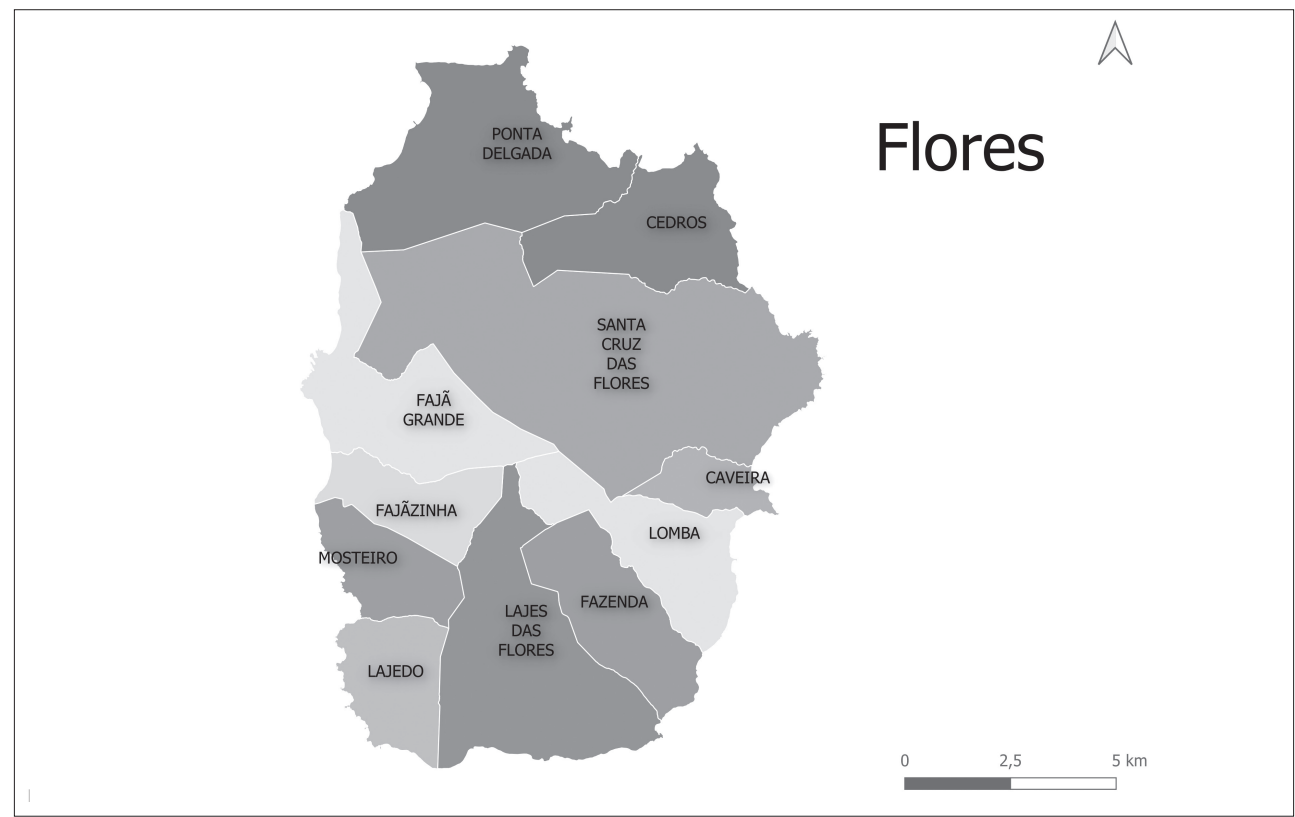

Mapa 3. Flores

Fonte: CAOP2013/Casa de Sarmento - CEP 
Tabela 4. Freguesias das Flores - R.C./Artigo

\begin{tabular}{l|c|c|c}
\hline \multicolumn{1}{c|}{ Freguesias } & R.C. & N. ${ }^{\circ}$ de artigos & R.C./artigo \\
\hline Santa Cruz das Flores & $9324 \$ 961$ & 2939 & $3 \$ 173$ \\
\hline Cedros & $1502 \$ 964$ & 1160 & $1 \$ 296$ \\
\hline Caveira & $974 \$ 144$ & 575 & $1 \$ 694$ \\
\hline Ponta Delgada & $5974 \$ 472$ & 3279 & $1 \$ 822$ \\
\hline Lajes das Flores & $8044 \$ 174$ & 4712 & $1 \$ 707$ \\
\hline Fajã Grande & $2232 \$ 274$ & 3612 & $\$ 618$ \\
\hline Fajãzinha & $1266 \$ 580$ & 1942 & $\$ 652$ \\
\hline Lajedo & $1191 \$ 098$ & 1435 & $\$ 830$ \\
\hline Lomba & $2574 \$ 006$ & 1888 & $1 \$ 363$ \\
\hline Mosteiro & $925 \$ 779$ & 1177 & $\$ 786$ \\
\hline
\end{tabular}

Fonte: Elaboração da autora

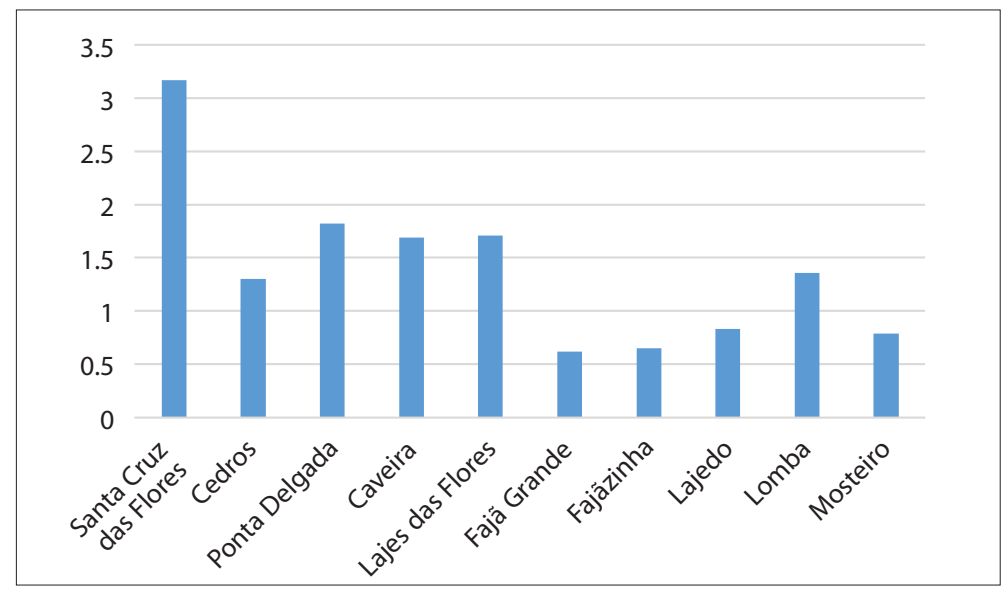

\section{Gráfico 3.}

Freguesias das Flores - R.C./Artigo Fonte: Elaboração da autora

Nas Flores, é na vila de Santa Cruz das Flores que a média por artigo matricial é mais elevada, seguida pela freguesia de Ponta Delgada, que se sobrepõe, embora ligeiramente, à vila das Lajes. Fajã Grande, Fajãzinha, Mosteiro e Lajedo são as freguesias que não atingem os $1 \$ 000$ réis por artigo matricial, embora acima dos $\$ 600$ réis.

Um indicador menos grosseiro e mais elucidativo para avaliar da riqueza relativa das populações será o rendimento coletável por habitante.

Para um ano central de levantamento das matrizes prediais, o de 1884, tivemos acesso ao número de habitantes por freguesia para todas as ilhas do ex-distrito da Horta $^{5}$. Sabendo-se que o espaço útil de cada freguesia não era necessariamente usufruído pelos próprios residentes, não podemos desenvolver um cálculo simples de divisão do rendimento coletável referido a cada freguesia pelo número de habitantes. 
Impõe-se, caso a caso, identificar todos os proprietários de fora, subtraindo o seu rendimento coletável e acrescentando-o na própria freguesia de residência.

Embora os mapas de proprietários indiquem o lugar de residência na própria freguesia e identifiquem as freguesias dos residentes fora, há exceções quando se trata de proprietários residentes noutra ilha, mas o caso mais frequente é o dos proprietários das freguesias urbanas do Faial, que são muitas vezes referidos como residentes na Horta, no caso de serem proprietários no Pico ou simplesmente na cidade, no caso de serem proprietários em freguesias rurais do Faial.

Embora em todas as freguesias do Pico se encontrem proprietários do Faial, era na terra ardida, na extensão que vai de Santa Luzia a São Mateus (na altura englobando ainda São Caetano), onde faialenses, principalmente hortenses, eram dominantemente proprietários de extensões apreciáveis de vinhas ou figueiras.

Será interessante salientar essa situação.

Tabela 5. Propriedade detida por não residentes nas freguesias da terra ardida do Pico (\%)

\begin{tabular}{l|l}
\hline Santa Luzia & 18,4 \\
\hline Bandeiras & 12,6 \\
\hline Madalena & 34,0 \\
\hline Criação Velha & 27,2 \\
\hline Candelária & 21,8 \\
\hline São Mateus & 11,4 \\
\hline
\end{tabular}

Fonte: Elaboração da autora

Reparemos que 34\% do valor coletável na freguesia da Madalena pertencia a proprietários de fora, seguindo-se Criação Velha e Candelária e depois Santa Luzia, esta já pertencente ao concelho de São Roque do Pico.

Considerando o rendimento coletável no Pico de residentes no Faial e o rendimento coletável no Faial de residentes no Pico, e sendo depreciável o número de proprietários de fora nas Flores e Corvo, a partir do número de habitantes em cada ilha em 1884, podemos começar por calcular, por ilha, o rendimento coletável por habitante.

Tabela 6. R.C./habitante/ilha (réis)

\begin{tabular}{l|r|r|r|r|r|r}
\hline \multicolumn{1}{c|}{ Ilhas } & \multicolumn{1}{c|}{ a) } & \multicolumn{1}{c|}{ b) } & \multicolumn{1}{c|}{ c) } & \multicolumn{1}{c}{ d) } & \multicolumn{1}{c}{ e) } & f) \\
\hline Pico & $63503 \$ 470$ & $13760 \$ 310$ & $8429 \$ 646$ & $58172 \$ 806$ & 25977 & $2 \$ 239$ \\
\hline Faial & $144419 \$ 274$ & $31221 \$ 741$ & $48819 \$ 239$ & $161534 \$ 420$ & 24484 & $6 \$ 543$ \\
\hline Flores & $31778 \$ 180$ & & & & 10003 & $3 \$ 177$ \\
\hline Corvo & $3906 \$ 991$ & & & & 849 & $4 \$ 601$ \\
\hline
\end{tabular}

Legenda: a) R.C. da ilha; b) R.C. na ilha de não residentes; c) R.C. fora da ilha dos residentes; d) R.C. global dos residentes; e) Habitantes; f) R.C. por habitante

Fonte: Elaboração da autora

Verificamos, por este indicador, que, apesar dos residentes no Pico terem já adquirido alguma terra no Faial, de onde iam buscar o alimento básico, o milho, a balança pendia fortemente para os faialenses com propriedade no Pico. 
Os habitantes do Pico eram claramente mais pobres do que os habitantes das outras ilhas que formavam então o distrito da Horta. Teriam apenas um terço do rendimento dos faialenses, metade do rendimento dos corvinos, distanciando-se ainda dos florentinos, os segundos mais pobres.

Estes são números médios que não expressam a penúria com a qual terão vivido as populações do Pico, particularmente as que construíram a paisagem classificada.

Tabela 7. R.C./habitante/Pico (réis)

\begin{tabular}{l|c|c|c|c|c|c}
\hline \multicolumn{1}{c|}{ Freguesias } & a) & b) & c) & d) & e) & f) \\
\hline Bandeiras & $2221 \$ 128$ & $503 \$ 096$ & $259 \$ 934$ & $1977 \$ 966$ & 967 & $2 \$ 045$ \\
\hline Madalena & $9536 \$ 014$ & $4131 \$ 420$ & $656 \$ 286$ & $6060 \$ 880$ & 2186 & $2 \$ 773$ \\
\hline Criação Velha & $1799 \$ 983$ & $625 \$ 358$ & $694 \$ 755$ & $1869 \$ 380$ & 903 & $2 \$ 070$ \\
\hline Candelária & $2760 \$ 775$ & $965 \$ 258$ & $153 \$ 307$ & $1948 \$ 824$ & 1612 & $1 \$ 209$ \\
\hline São Mateus & $5174 \$ 120$ & $892 \$ 888$ & $250 \$ 046$ & $4531 \$ 278$ & 3119 & $1 \$ 453$ \\
\hline São João & $2883 \$ 272$ & $183 \$ 418$ & $475 \$ 340$ & $3175 \$ 194$ & 1222 & $2 \$ 598$ \\
\hline Lajes do Pico & $8315 \$ 915$ & $1026 \$ 020$ & $693 \$ 462$ & $7983 \$ 357$ & 3345 & $2 \$ 387$ \\
\hline Ribeiras & $4777 \$ 650$ & $1865 \$ 090$ & $282 \$ 834$ & $3195 \$ 394$ & 2276 & $1 \$ 404$ \\
\hline Calheta de Nesquim & $3859 \$ 239$ & $694 \$ 419$ & $2252 \$ 059$ & $5416 \$ 879$ & 1175 & $4 \$ 610$ \\
\hline Piedade & $6894 \$ 925$ & 7914933 & $532 \$ 842$ & $6635 \$ 834$ & 2368 & $2 \$ 802$ \\
\hline Santo Amaro & $2051 \$ 715$ & $309 \$ 651$ & $101 \$ 091$ & $1843 \$ 155$ & 862 & $2 \$ 139$ \\
\hline Prainha & $3719 \$ 512$ & $67 \$ 141$ & $174 \$ 186$ & $3826 \$ 557$ & 1570 & $2 \$ 437$ \\
\hline São Roque do Pico & $4011 \$ 291$ & $349 \$ 176$ & $1009 \$ 891$ & $4672 \$ 006$ & 1798 & $2 \$ 598$ \\
\hline Santo António & $3264 \$ 222$ & $319 \$ 446$ & $686 \$ 047$ & $3630 \$ 823$ & 1399 & $2 \$ 595$ \\
\hline Santa Luzia & $2233 \$ 708$ & $1035 \$ 993$ & $207 \$ 566$ & $1405 \$ 281$ & 1175 & $1 \$ 196$ \\
\hline
\end{tabular}

Legenda: a) R.C. da ilha; b) R.C. na ilha de não residentes; c) R.C. fora da ilha dos residentes; d) R.C. global dos residentes; e) Habitantes; f) R.C. por habitante

Fonte: Elaboração da autora

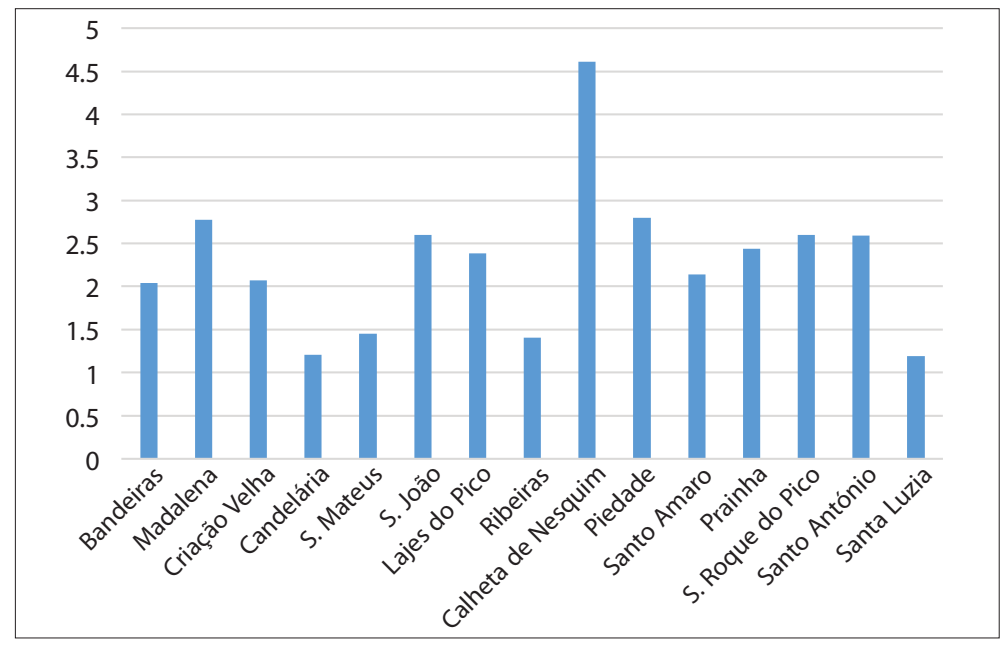

\section{Gráfico 4.}

Freguesias do Pico R.C./Habitante Fonte:

Elaboração da autora 
A freguesia mais pobre do Pico em meados da década de 1880 era a de Santa Luzia, não atingindo 1 \$200 réis de rendimento coletável por habitante, mas a grande pobreza também se estendia à Candelária, São Mateus ou Ribeiras, com rendimento coletável médio abaixo dos $1 \$ 500$ réis. Aliás, o rendimento coletável por habitante, à exceção do estranho caso da Calheta de Nesquim, não atinge em nenhum caso, os 3\$000 réis.

$\mathrm{O}$ caso da Calheta de Nesquim merecerá uma atenção particular, mas podemos desde já verificar que uma parte significativa do rendimento dos residentes advinha de propriedades fora do espaço da freguesia. Admitimos que a Calheta de Nesquim, tendo-se autonomizado como freguesia apenas em meados do século XVIII, estando integrada antes na Piedade, continuasse a explorar importantes espaços registados na freguesia-mãe.

Tabela 8. R.C./Habitante/Faial (réis)

\begin{tabular}{l|r|r|r|r|r|c}
\hline \multicolumn{1}{c|}{ Freguesias } & \multicolumn{1}{c|}{ a) } & \multicolumn{1}{c|}{ b) } & \multicolumn{1}{c|}{ c) } & \multicolumn{1}{c}{ d) } & \multicolumn{1}{c}{ e) } & f) \\
\hline Horta & $48212 \$ 280$ & $5183 \$ 048$ & $36790 \$ 550$ & $79919 \$ 782$ & 7141 & $11 \$ 178$ \\
\hline Flamengos & $9515 \$ 965$ & $1923 \$ 235$ & $6743 \$ 872$ & $14336 \$ 600$ & 2281 & $6 \$ 285$ \\
\hline Feteira & $18852 \$ 696$ & $5278 \$ 639$ & $717 \$ 398$ & $14291 \$ 460$ & 2364 & $6 \$ 045$ \\
\hline Castelo Branco & $14105 \$ 732$ & $2574 \$ 420$ & $356 \$ 971$ & $11888 \$ 280$ & 2108 & $5 \$ 640$ \\
\hline Capelo & $3049 \$ 085$ & $475 \$ 580$ & $148 \$ 333$ & $2721 \$ 838$ & 1405 & $1 \$ 937$ \\
\hline Praia do Norte & $1734 \$ 639$ & $267 \$ 412$ & $62 \$ 670$ & $1529 \$ 899$ & 686 & $2 \$ 230$ \\
\hline Cedros & $15980 \$ 306$ & $1094 \$ 475$ & $733 \$ 220$ & $15619 \$ 950$ & 3375 & $4 \$ 628$ \\
\hline Salão & $5964 \$ 950$ & $1360 \$ 100$ & $418 \$ 290$ & $5023 \$ 140$ & 1128 & $4 \$ 453$ \\
\hline Ribeirinha & $8898 \$ 065$ & $851 \$ 760$ & $329 \$ 745$ & $8376 \$ 050$ & 1133 & $7 \$ 393$ \\
\hline Pedro Miguel & $10425 \$ 585$ & $1368 \$ 090$ & $2082 \$ 950$ & $11140 \$ 450$ & 1693 & $6 \$ 580$ \\
\hline Praia do Almoxarife & $7679 \$ 971$ & $2834 \$ 199$ & $435 \$ 240$ & $5281 \$ 012$ & 1170 & $4 \$ 514$ \\
\hline
\end{tabular}

Legenda: a) R.C. da ilha; b) R.C. na ilha de não residentes; c) R.C. fora da ilha dos residentes; d) R.C. global dos residentes; e) Habitantes; f) R.C. por habitante

Fonte: Elaboração da autora

Gráfico 5.

Cidade da Horta e freguesias do Faial - R.C./Habitante Fonte: Elaboração da autora

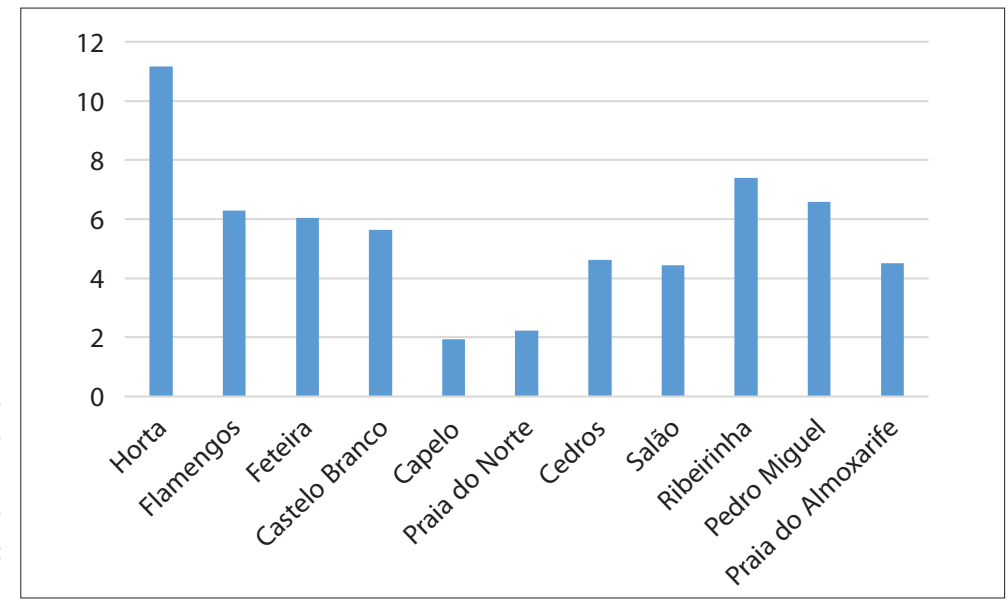


Para a ilha do Faial, reparamos que grande parte do rendimento dos residentes na cidade da Horta provinha, não só de propriedades no Pico, mas também de freguesias rurais da própria ilha. Também os residentes dos Flamengos tinham um volume importante de propriedades fora do espaço da freguesia, o que contrasta com o caso da Feteira, um bom celeiro, que atraíra principalmente proprietários da Horta e dos Flamengos, sem excluir outras freguesias, com relevo para proprietários do Pico.

Reparamos depois que apenas no Capelo e Praia do Norte não se atingiam os $2 \$ 500$ réis de rendimento coletável por habitante, posicionando-se todas as outras acima dos $4 \$ 000$ réis. O rendimento coletável de cada hortense ultrapassava os $11 \$ 000$ réis.

Tabela 9. R. C./ Habitante/Flores (réis)

\begin{tabular}{l|r|r|r|r|r|c}
\hline \multicolumn{1}{c|}{ Freguesias } & \multicolumn{1}{c|}{ a) } & \multicolumn{1}{c|}{ b) } & \multicolumn{1}{c|}{ c) } & \multicolumn{1}{c|}{ d) } & e) & f) \\
\hline Santa Cruz das Flores & $9324 \$ 961$ & $98 \$ 406$ & $894 \$ 491$ & $10121 \$ 950$ & 3038 & $3 \$ 331$ \\
\hline Cedros & $1502 \$ 964$ & $93 \$ 918$ & $65 \$ 826$ & $1474 \$ 872$ & 441 & $3 \$ 344$ \\
\hline Caveira & $974 \$ 144$ & $550 \$ 230$ & $10 \$ 876$ & $434 \$ 790$ & 256 & $1 \$ 698$ \\
\hline Ponta Delgada & $5974 \$ 472$ & $148 \$ 571$ & $51 \$ 396$ & $5877 \$ 297$ & 1131 & $5 \$ 197$ \\
\hline Lajes das Flores & $8044 \$ 174$ & $182 \$ 558$ & $276 \$ 174$ & $8137 \$ 790$ & 1855 & $4 \$ 387$ \\
\hline Fajã Grande & $2232 \$ 274$ & $150 \$ 354$ & $97 \$ 901$ & $2179 \$ 821$ & 1190 & $1 \$ 832$ \\
\hline Fajãzinha & $1266 \$ 580$ & $74 \$ 748$ & $361 \$ 966$ & $1553 \$ 798$ & 698 & $2 \$ 226$ \\
\hline Lajedo & $1191 \$ 098$ & $339 \$ 458$ & $25 \$ 076$ & $876 \$ 716$ & 366 & $2 \$ 395$ \\
\hline Lomba & $2574 \$ 006$ & $183 \$ 448$ & $130 \$ 151$ & $2520 \$ 709$ & 810 & $3 \$ 112$ \\
\hline Mosteiro & $925 \$ 779$ & $298 \$ 886$ & $98 \$ 412$ & $725 \$ 305$ & 218 & $3 \$ 327$ \\
\hline
\end{tabular}

Legenda: a) R.C. da freguesia; b) R.C. na freguesia de não residentes; c) R.C. fora da freguesia dos residentes; d) R.C. global dos residentes; e) Habitantes; f) R.C. por habitante

Fonte: Elaboração da autora

Nas Flores, apenas os residentes na Caveira e Fajã Grande contabilizavam menos de $2 \$ 000$ réis de rendimento coletável por habitante. No primeiro caso, cerca de metade do valor coletável da freguesia pertencia a gente de fora, dominantemente de residentes em Santa Cruz. Ponta Delgada era a freguesia de solo mais rico, ultrapassando os $5 \$ 000$ réis de rendimento coletável por habitante, sobrepondo-se mesmo a qualquer uma das vilas, Lajes ou Santa Cruz das Flores.

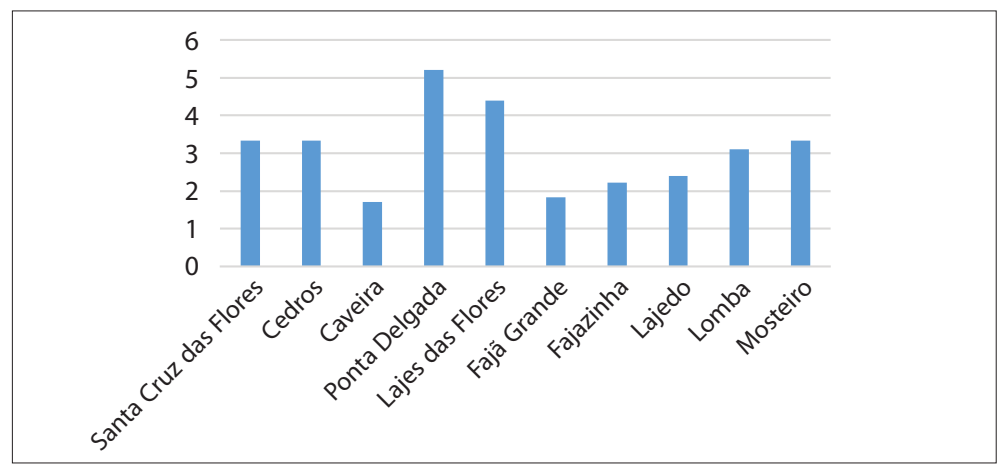

\section{Gráfico 6.}

Freguesias das Flores

- R.C./Habitante

Fonte:

Elaboração da autora 


\section{COMPORTAMENTOS DEMOGRÁFICOS COMPARADOS}

Sendo Santa Luzia a freguesia mais pobre do Pico e Ponta Delgada a mais rica das Flores, com dimensões de população muito próximas, será interessante contrastar comportamentos demográficos de uma e de outra.

Começamos por observar, para Santa Luzia e Ponta Delgada, na longa duração, a evolução dos nascimentos, comparada com a evolução dos óbitos, para o período em que se dispõe do registo de todos os falecidos. Consideradas as crianças até aos 7 anos como anjos, que não necessitavam da intervenção da Igreja para a sua salvação, é muitas vezes tardio o registo do seu falecimento. No caso vertente, o registo sistemático de mortalidade infantil na paróquia picoense precede de quatro décadas o da paróquia florentina.

Gráfico 7. Movimento natural — Santa Luzia

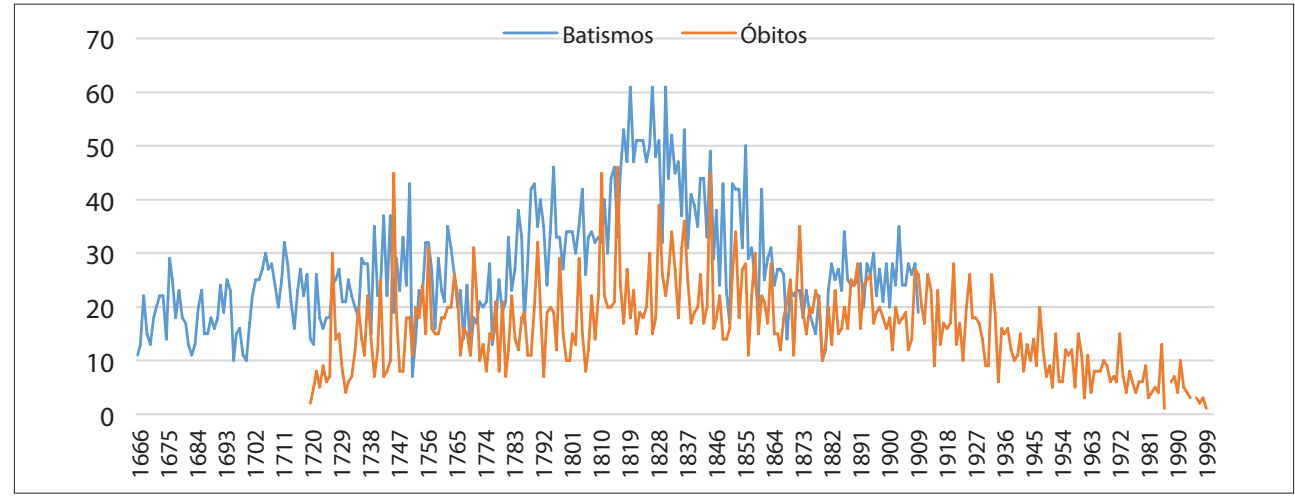

Fonte: Elaboração da autora

Em Santa Luzia encontramos duas grandes fases de evolução dos nascimentos muito marcadas, a de crescimento até à década de 1830, e a posterior, de regressão intensa, até à década de 1880 , com algum crescimento até final da nossa observação sobre os nascimentos, que se queda em 1909, embora se prolongue, no caso dos óbitos, até ao início deste século XXI. O crescimento no século XVIII foi afetado pela sobremortalidade de $1746^{6}$ e pela emigração a que a fome obrigou, primeiro para outras ilhas e depois para o Brasil, aproveitando as facilidades dadas pela Coroa portuguesa para a colocação de casais açorianos nas fronteiras da grande colónia. Um crescimento acelerado delineia-se logo a partir do último quartel do século XVIII, ultrapassando-se os 60 nascimentos por ano no início da década de 1830, altura em que se dá a rutura com os recursos disponíveis, bem antes da crise das vinhas, que só se daria em 1852. A emigração massiva de gente

${ }^{6}$ AMORIM, 2016: 39. 
jovem fez cair drasticamente o volume de nascimentos, encontrando-se menos de 20 nascimentos por ano na década de 1870 . As três décadas seguintes permitiram uma ligeira recuperação.

Observando os saldos fisiológicos, verificamos que, se excetuarmos, para o século XVIII, a sobremortalidade dos anos de 1727, 1746 e 1771, para o século XIX, embora se marquem as epidemias de varíola de 1811, 1816 e 1845, os picos de óbitos pouco se sobrepõem aos nascimentos, o mesmo não acontecendo com a crise de varíola de 1873, já em período regressivo.

Gráfico 8. Movimento natural — Ponta Delgada

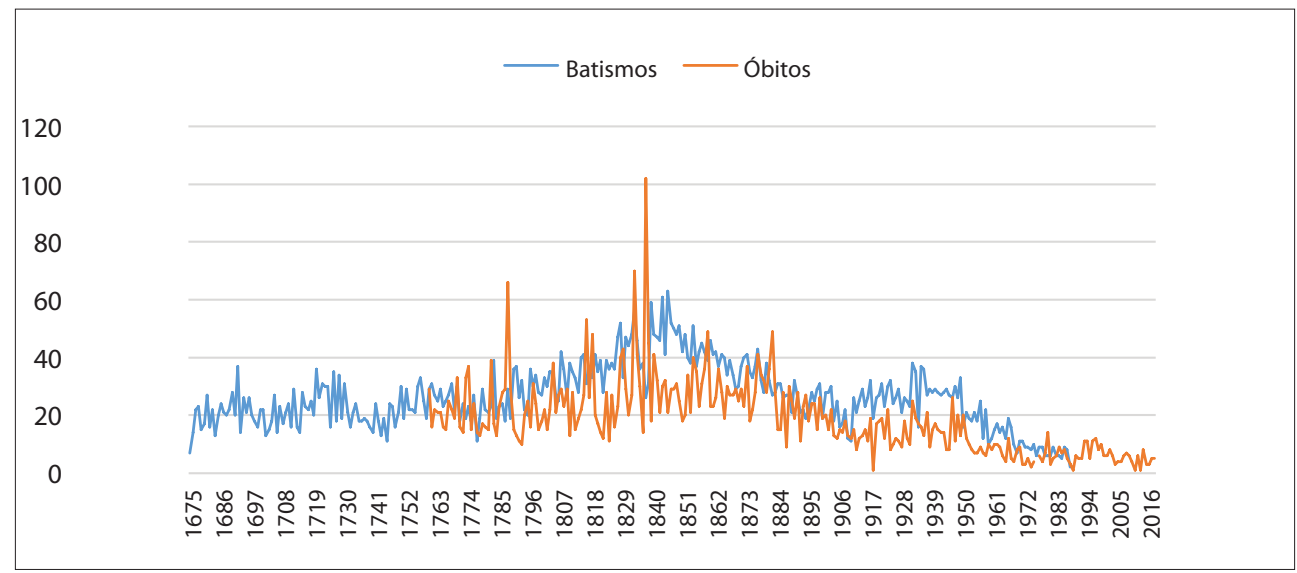

Fonte: Elaboração da autora

Em Ponta Delgada, o aumento do volume de nascimentos é também expressivo na primeira metade do século XIX, passando de menos de 40 nascimentos por ano, nos finais do século XVIII, para mais de 60 em meados da década de 1840. Dá-se depois a regressão, com menos de 20 nascimentos no início do século XX. Prolongando-se a observação de batizados pelo século XX, verificamos que o corte da emigração para os Estados Unidos faz elevar o volume de nascimentos entre 1920 e 1950, mas a partir de então a regressão é muito marcada, pela nova abertura aos Estados Unidos e também ao Canadá e efeitos da contraceção.

Reparamos depois que as crises de mortalidade em Ponta Delgada atingiram níveis bem mais importantes do que os encontrados em Santa Luzia, particularmente a crise de 1837, que pelo testemunho do pároco, sabemos ser de varíola. Dentro do observado, os saldos fisiológicos são persistentemente menos positivos dos que os encontrados na paróquia picoense.

A comparação das curvas de batizados numa e noutra paróquia permite-nos uma comparação mais clara sobre a dinâmica até 1910. 
Gráfico 9. Movimento natural comparado - Santa Luzia e Ponta Delgada

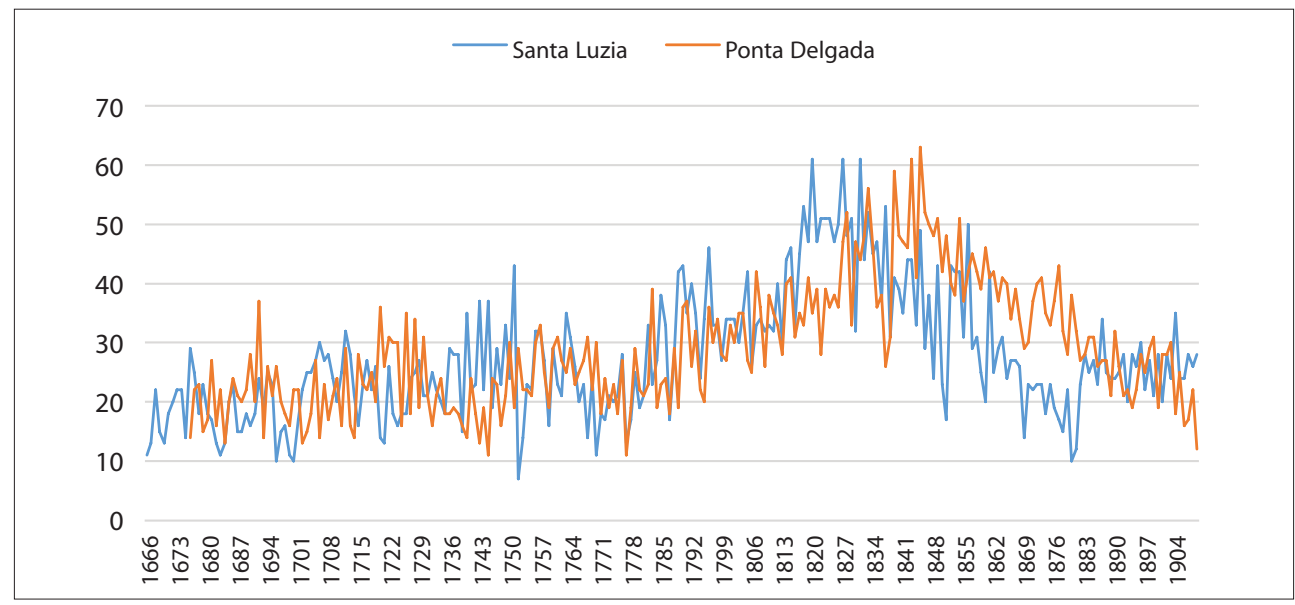

Fonte: Elaboração da autora

Até à segunda década do século XIX, a sobreposição das duas curvas de batizados evidencia um movimento sensivelmente paralelo, embora com oscilações, notando-se maiores dificuldades de crescimento em Ponta Delgada na primeira metade do século XVIII, uma retração mais marcada em meados do século em Santa Luzia, retração que se vai marcar na paróquia florentina no último quartel desse mesmo século. $\mathrm{O}$ maior desfasamento entre as duas paróquias irá verificar-se a partir da segunda década do século XIX. Enquanto em Santa Luzia a última data em que encontramos o valor mais alto de nascimentos é o ano de 1831, esse valor mais alto só é encontrado em Ponta Delgada em 1845, com queda posterior contínua. Admitimos que em Santa Luzia a rutura com os recursos obrigaria mais cedo a uma emigração de massas, mas outros comportamentos podem justificar as diferenças.

Antes de entrarmos no século XX, num quadro comum de fecundidade próxima da natural, as fases de contenção ou crescimento poderão refletir tanto comportamentos mais volitivos como a idade ao casar, o celibato definito ou a mobilidade, como a mortalidade de crise ou a mortalidade comum, com níveis diferenciados de esperança de vida. Importa comparar esses comportamentos nas duas comunidades.

\subsection{Comportamentos comparados de nupcialidade - idade média ao primeiro casamento}

As razões do incremento mais expressivo do volume de nascimentos na primeira metade do século XIX, poderá procurar-se primeiro nas alterações da idade ao casamento, particularmente no sexo feminino. Uma idade mais precoce ao casamento nas mulheres poderia significar um período mais longo de convivência conjugal e um maior número de filhos. 
Começamos, por isso, por apresentar as idades médias ao casamento, em análise transversal, por décadas, observando os casamentos realizados 50 anos após o início do registo de batizados. Considere-se que, quase sempre, só no século XX há indicação no ato de casamento da idade dos nubentes pelo que se torna necessário, na observação em causa, identificar os nubentes ao nascimento e excluir a possibilidade de estarmos a privilegiar casamentos mais precoces.

Gráfico 10. Santa Luzia — Idade média ao primeiro casamento

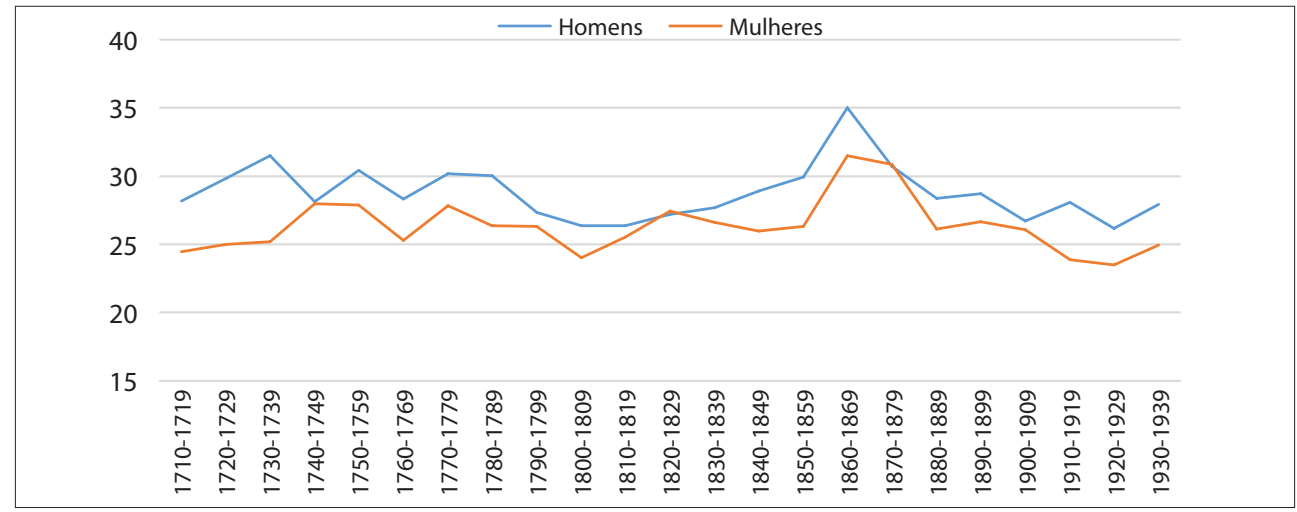

Fonte: Elaboração da autora

Em Santa Luzia, as idades médias ao casamento feminino apresentam-se muito elevadas, oscilando entre os 25 e os 27 anos entre 1710 e 1860, subindo para 31 anos nas décadas de 1860 e 1870, período mais afetado pelo movimento emigratório massivo. Nas décadas seguintes dá-se um abaixamento, colocando-se, a partir da segunda década do século XX, em valores abaixo dos 25 anos. Os homens casaram à volta dos 30 anos até entrarmos nas últimas décadas do século XVIII, chegando a atingir os 35 anos na década de 1860, iniciando depois o movimento descendente, mas não baixando dos 26 anos.

Gráfico 11. Ponta Delgada — Idade média ao primeiro casamento

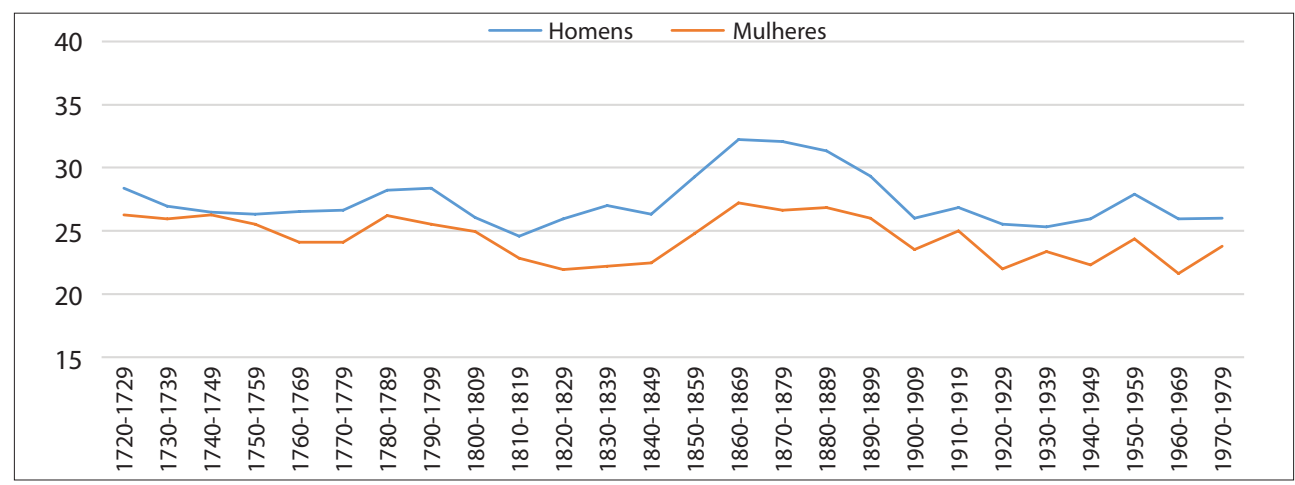

Fonte: Elaboração da autora 
Em Ponta Delgada casava-se mais cedo, o que poderia fazer supor um crescimento mais sustentado do volume de nascimentos, relativamente a Santa Luzia, o que vimos não ter acontecido. No século XVIII a idade média ao primeiro casamento feminino na paróquia florentina oscilava à volta dos 25 anos, 1 a 2 anos menos do que em Santa Luzia, mas na década de 1820, a média de idade ao casamento feminino queda-se nos 22 anos, a justificar em parte a subida pronunciada de nascimentos verificada no período. Após 1850 as médias sobem, já ultrapassando os 25 anos, atingindo na década de 1860 os 27 anos, a década crítica nas duas comunidades no que respeita a este comportamento. Dá-se um abaixamento posterior que chega aos 24 anos na primeira década do século XX, com ténues oscilações posteriores.

O desfasamento entre a idade ao casar de homens e mulheres é maior na paróquia florentina, chegando a atingir 5 anos de diferença na década de 1860.

\subsection{Comportamentos comparados de nupcialidade - celibato definitivo}

A par das alterações na idade ao primeiro casamento feminino, o número de pessoas que não chegaram a casar em tempo útil para deixarem descendência pode ser também uma variável influente na evolução dos batizados, dado que, nessa sociedade tradicional, por norma, os nascimentos aconteciam dentro do casamento.

Para avaliarmos a percentagem de definitivamente celibatários nas duas comunidades, considerámos, por períodos, o volume de falecidos com 50 ou mais anos e desses quantos faleceram no estado de solteiros. Trata-se da observação possível, embora a idade ao óbito esteja naturalmente desfasada da idade núbil.

Tabela 10. Celibato definitivo

\begin{tabular}{c|c|c|c|c}
\hline \multirow{2}{*}{ Períodos } & \multicolumn{2}{|c|}{ Santa Luzia } & H & M \\
\cline { 2 - 5 } & H & H & 14 & 17 \\
\hline $1780-1819$ & 7 & 14 & 10 & 19 \\
\hline $1820-1859$ & 7 & 7 & 11 & 35 \\
\hline $1860-1899$ & 12 & 28 & 17 & 32 \\
\hline $1900-1939$ & 18 & 40 & \\
\hline
\end{tabular}

Fonte: Elaboração da autora

Verificamos, pelo quadro, que o celibato definitivo, particularmente o celibato feminino não é depreciável em nenhum período observado e em nenhuma das duas paróquias.

Se excluirmos o último período observado, reparamos que o celibato definitivo foi bem mais frequente na terra mais produtiva do que na terra pobre, particularmente no que respeita ao sexo masculino. A necessidade de manter o estatuto de nascimento apresenta-se como uma primeira explicação. 
A incidência do celibato marca-se, no entanto, para os falecidos depois de 1860, aqueles que, em idade núbil, começaram a ser mais afetados pelas alterações profundas provocadas pela intensificação da mobilidade. Sabemos que a mobilidade massiva foi fortemente diferencial, a deixar muitas mulheres sem parceiro. Cerca de um terço das mulheres que morreram entre 1860 e 1940, numa e noutra comunidade não chegaram a casar, com especial relevo para as falecidas em Santa Luzia nos primeiros 40 anos do século XX.

\subsection{Fecundidade ilegítima e expostos}

O celibato definitivo terá tido naturais reflexos nos nascimentos fora do casamento, não só o celibato definitivo feminino, mas também o masculino. Níveis mais altos de ilegitimidade podem ser provocados pelo maior volume de homens que não chegaram a casar.

Tabela 11. Fecundidade ilegítima e expostos

\begin{tabular}{c|c|c|c|c}
\hline \multirow{2}{*}{ Períodos } & \multicolumn{2}{|c|}{ Santa Luzia } & \multicolumn{2}{c}{ Ponta Delgada } \\
\cline { 2 - 5 } & Ileg. & Exp. & Ileg. & Exp. \\
\hline $1790-1829$ & 4,4 & 8,6 & 12,9 & 0,3 \\
\hline $1830-1869$ & 5,6 & 9,4 & 19,9 & 0,6 \\
\hline $1870-1899$ & 9,2 & 3,2 & 14,8 & 2,1 \\
\hline $1900-1929$ & 8,3 & 0,3 & 8,9 & 0,1 \\
\hline
\end{tabular}

Fonte: Elaboração da autora

O quadro evidencia, de facto, em Ponta Delgada, marcada diferença na percentagem de filhos nascidos fora do casamento de mãe conhecida, a aproximar-se dos $20 \%$ nos anos centrais do século XIX, enquanto em Santa Luzia não se atinge, paralelamente, os 6\%. No entanto, o abandono de crianças tem pouca expressão em Ponta Delgada, o mesmo não acontecendo na paróquia picoense, com valores à volta dos $9 \%$ entre 1790 e 1869. Repare-se que nas três décadas finais do século XIX sobe em Santa Luzia a percentagem de filhos nascidos fora do casamento de mãe conhecida para descer a percentagem de crianças abandonadas, perdendo expressão o fenómeno do abandono no século XX. Não podemos, no entanto, pensar que todas as crianças abandonadas e que foram registadas em Santa Luzia eram da responsabilidade da própria paróquia. Dada a pobreza da comunidade, muitas mulheres juntavam algum rendimento aos fracos recursos domésticos servindo como amas de expostos e é admissível que crianças oriundas das freguesias vizinhas, particularmente das vilas da Madalena e de São Roque do Pico, aí fossem abandonadas ${ }^{7}$.

\footnotetext{
${ }^{7}$ AMORIM, 2016: 50.
} 


\subsection{Comportamentos comparados de mortalidade}

Dados os eventuais problemas das fontes e o fenómeno perturbador constituído pela mobilidade, o estudo do principal indicador da mortalidade, a esperança de vida à nascença, em análise longitudinal, é um estudo complexo.

Podemos debater-nos, nestas ilhas, principalmente até meados do século XVIII, com o não registo ou sub-registo de mortalidade infantil, como vimos anteriormente, o que protela a observação.

Mesmo beneficiando de registos sistemáticos, o estudo longitudinal da mortalidade, além de exigir o acompanhamento das gerações ao longo dos 100 anos posteriores ao nascimento, parte de algumas convenções. Uma primeira convenção é o acompanhamento em cada paróquia ou zona observada, apenas dos indivíduos para os quais conhecemos a data de nascimento. Para Santa Luzia, o acompanhamento de percursos foi feito por toda a ilha e pela zona de maior atração exterior, a cidade da Horta, na ilha do Faial. No caso de Ponta Delgada, não se dispondo ainda de bases de dados para todas as paróquias da ilha, limitámo-nos a acompanhar os percursos dentro da freguesia.

Além dos indivíduos nascidos e falecidos em cada freguesia ou na área mais alargada observada, encontramos outros indivíduos aí nascidos cujo destino desconhecemos. Na ausência de lacunas nos registos ou sub-registo de menores, trata-se de indivíduos que se ausentaram e para os quais não temos data de ausência, a não ser a decorrente do cruzamento com os registos de passaportes, que só cobrem a emigração legal. Esse trabalho de cruzamento dos registos de passaportes nas bases de dados genealógicas foi desenvolvido para Santa Luzia, mas não para Ponta Delgada.

Nos casos em que não acompanhamos até à morte indivíduos nascidos na comunidade, para marcar um fim de observação, caso a caso, não se dispondo de registo de passaporte, usámos convenções.

Consideremos que a mobilidade pode afetar famílias ou indivíduos isolados.

A mobilidade familiar deteta-se pela ausência de qualquer registo, seja de batizado ou óbito, a partir de determinado momento, para qualquer membro de uma família para a qual estamos a acompanhar o percurso pelo casamento ou nascimento de filhos. Convencionámos, para este caso, que a última data familiar conhecida, seria o fim da observação para todo e qualquer membro dessa família. Essa data poderá ser o nascimento do último filho conhecido ou o óbito posterior do mesmo ou de um irmão nascido anteriormente. Trata-se, naturalmente, de uma marcação de fim de observação, por defeito.

A mobilidade isolada pode afetar não só os filhos de determinada família, mas também algum dos progenitores. No caso de não conhecermos a data de óbito de apenas um dos progenitores, considerámos como fim de observação, para o mesmo, a última data em que o sabemos presente, seja a data de casamento sem nenhuma 
informação posterior, o nascimento de um filho, a morte de um outro, ou o óbito do outro cônjuge no estado de casado, continuando a tratar-se de uma marcação, por defeito.

No caso de se tratar de indivíduos dos quais apenas conhecemos a data de nascimento e que se integram em famílias consideradas estáveis, marcámos como fim de observação os 20 anos exatos do mesmo. Esse é um procedimento que temos vindo a adotar desde o estudo das Três Paroquias do Sul do Pico ${ }^{8}$, considerando os 20 anos como uma idade charneira entre o afastamento por motivos de trabalho (na maior parte dos casos, uma emigração intercontinental, geralmente mais precoce) ou de casamento no exterior (geralmente em idades mais elevadas). Sabemos, no entanto, que essa idade média de afastamento isolado pode variar com o tempo, embora, na aproximação aos resultados pretendidos, se possa beneficiar da menor acuidade da mortalidade nessas idades.

Este trabalho de marcação de fim de observação, caso a caso, em alguns milhares de indivíduos, é um trabalho delicado, de minúcia, necessariamente muito moroso, mas é o procedimento que nos permite uma maior aproximação ao número de indivíduos em risco de óbito, em cada freguesia, em cada idade, em determinado ano, avaliando depois quantos desses efetivamente faleceram nessa mesma idade.

Partimos depois do princípio de que os indivíduos que se ausentaram teriam, em relação aos observados, um comportamento semelhante perante a morte.

Para oito das 16 freguesias do Pico, a partir de 1992, fomos obtendo resultados sucessivos, em termos de comportamentos demográficos, sempre com a estranheza sobre a suavidade da morte, tanto nas primeiras idades como nas idades mais elevadas, o que nos levou à publicação de um artigo sobre essa problemática9 .

Em Santa Luzia encontramos um registo de mortalidade infantil tendencialmente sistemático desde a década de 1720 e o acompanhamento do percurso prolonga-se pelo século XXI, o que nos permitiria o cálculo da esperança de vida à nascença para as gerações nascidas entre 1720 e $1910^{10}$.

No entanto, em Ponta Delgada o registo de óbitos tendencialmente sistemático só se encontra a partir de 1760. Nesta observação, para maior facilidade, considerámos apenas três períodos: 1790-1829, 1830-1869 e 1870-1899. Embora a observação seja feita ano a ano, para facilitar a leitura, apresentamos em quadro apenas a esperança de vida aos 0 anos, a um ano e depois em intervalos quinquenais, terminando aos 85 anos.

\footnotetext{
${ }^{8}$ AMORIM, 1992.

${ }^{9}$ AMORIM, 2004.

${ }^{10}$ AMORIM, 2016: 65.
} 
Tabela 12. Esperança de vida à nascença (gerações nascidas entre 1790 e 1889 - comparação entre Santa Luzia e Ponta Delgada)

\begin{tabular}{|c|c|c|c|c|c|c|c|c|c|c|c|c|c|c|c|c|c|c|}
\hline & \multicolumn{6}{|c|}{$\begin{array}{l}\text { Gerações nascidas } \\
\text { entre } 1790 \text { e } 1829\end{array}$} & \multicolumn{6}{|c|}{$\begin{array}{l}\text { Gerações nascidas } \\
\text { entre } 1830 \text { e } 1869\end{array}$} & \multicolumn{6}{|c|}{$\begin{array}{l}\text { Gerações nascidas } \\
\text { entre } 1870 \text { e } 1899\end{array}$} \\
\hline & \multicolumn{3}{|c|}{ Santa Luzia } & \multicolumn{3}{|c|}{ Ponta Delgada } & \multicolumn{3}{|c|}{ Santa Luzia } & \multicolumn{3}{|c|}{ Ponta Delgada } & \multicolumn{3}{|c|}{ Santa Luzia } & \multicolumn{3}{|c|}{ Ponta Delgada } \\
\hline & M & $\mathbf{F}$ & MF & M & $\mathbf{F}$ & MF & M & $\mathbf{F}$ & MF & M & $\mathbf{F}$ & MF & M & $\mathbf{F}$ & MF & M & $\mathbf{F}$ & MF \\
\hline 0 & 51,7 & 54,0 & 53,0 & 42,3 & 40,2 & 41,2 & 52,2 & 52,2 & 52,2 & 40,4 & 40,7 & 40,4 & 53,0 & 54,3 & 53,6 & 42,5 & 46,7 & 44,9 \\
\hline 1 & 57,9 & 59,5 & 58,9 & 51,3 & 48,5 & 49,9 & 58,7 & 58,6 & 58,7 & 49,7 & 48,0 & 48,8 & 58,9 & 60,8 & 59,8 & 52,0 & 56,4 & 54,6 \\
\hline 5 & 59,3 & 64,4 & 62,1 & 53,0 & 51,7 & 52,3 & 62,6 & 62,3 & 62,5 & 56,7 & 53,7 & 55,0 & 63,5 & 63,5 & 63,4 & 58,1 & 62,8 & 60,9 \\
\hline 10 & 56,4 & 60,2 & 58,5 & 49,5 & 48,4 & 48,9 & 59,7 & 59,6 & 59,7 & 54,8 & 50,4 & 52,9 & 59,8 & 58,7 & 59,2 & 55,5 & 59,3 & 57,9 \\
\hline 15 & 52,4 & 55,7 & 54,3 & 46,2 & 44,4 & 45,3 & 55,3 & 55,5 & 55,5 & 50,9 & 47,9 & 49,2 & 55,3 & 54,7 & 54,9 & 51,8 & 55,2 & 54,1 \\
\hline 20 & 48,1 & 51,6 & 50,1 & 41,9 & 41,2 & 41,5 & 51,1 & 51,0 & 51,1 & 46,5 & 44,1 & 45,1 & 51,5 & 50,2 & 50,7 & 47,0 & 51,0 & 49,6 \\
\hline 25 & 44,2 & 47,7 & 46,2 & 38,3 & 38,1 & 38,2 & 46,8 & 47,5 & 47,2 & 41,8 & 41,3 & 41,5 & 47,1 & 46,7 & 46,9 & 43,9 & 48,2 & 46,7 \\
\hline 30 & 40,5 & 43,7 & 42,3 & 35,3 & 34,6 & 34,9 & 42,1 & 43,2 & 42,8 & 38,2 & 38,9 & 38,7 & 44,7 & 43,0 & 42,8 & 39,5 & 44,4 & 42,6 \\
\hline 35 & 37,2 & 39,8 & 38,7 & 30,3 & 31,5 & 31,0 & 37,9 & 39,6 & 38,9 & 34,6 & 35,8 & 35,4 & 39,4 & 37,7 & 38,4 & 35,5 & 40,5 & 38,7 \\
\hline 40 & 32,9 & 36,2 & 34,8 & 27,7 & 28,8 & 28,3 & 33,0 & 35,8 & 34,6 & 29,9 & 32,2 & 31,3 & 34,4 & 33,9 & 34,1 & 31,0 & 35,9 & 34,1 \\
\hline 45 & 29,5 & 32,1 & 31,0 & 24,2 & 25,0 & 24,7 & 28,8 & 32,2 & 30,7 & 27,4 & 28,8 & 28,3 & 29,8 & 29,8 & 29,8 & 27,0 & 31,9 & 30,2 \\
\hline 50 & 25,2 & 27,5 & 26,5 & 20,8 & 22,6 & 21,8 & 25,2 & 28,0 & 26,8 & 23,5 & 25,9 & 25,0 & 25,4 & 27,2 & 26,3 & 22,5 & 26,9 & 25,4 \\
\hline 55 & 20,9 & 23,6 & 22,5 & 17,3 & 18,5 & 18,0 & 20,8 & 23,6 & 22,4 & 20,2 & 21,6 & 21,1 & 21,2 & 22,5 & 21,8 & 18,9 & 22,2 & 21,1 \\
\hline 60 & 17,5 & 19,9 & 18,9 & 14,2 & 15,2 & 14,8 & 17,2 & 19,8 & 18,7 & 16,9 & 18,0 & 17,6 & 17,7 & 18,3 & 18,0 & 15,5 & 17,7 & 17,0 \\
\hline 65 & 13,8 & 16,1 & 15,2 & 11,6 & 12,3 & 12,0 & 13,1 & 15,7 & 14,6 & 13,5 & 14,7 & 14,3 & 14,3 & 14,9 & 14,6 & 12,2 & 14,2 & 13,6 \\
\hline 70 & 10,6 & 12,7 & 11,9 & 9,4 & 9,6 & 9,5 & 9,3 & 12,1 & 11,0 & 10,3 & 11,2 & 10,9 & 11,7 & 10,8 & 11,2 & 10,0 & 11,5 & 11,0 \\
\hline 75 & 8,1 & 9,7 & 9,1 & 6,5 & 7,1 & 6,8 & 6,7 & 8,9 & 8,1 & 7,4 & 9,1 & 8,5 & 8,5 & 8,1 & 8,3 & 7,8 & 8,9 & 8,6 \\
\hline 80 & 5,8 & 7,0 & 6,6 & 5,1 & 5,8 & 5,5 & 4,8 & 6,2 & 5,8 & 5,5 & 6,3 & 6,0 & 6,1 & 6,1 & 6,0 & 6,6 & 6,5 & 6,5 \\
\hline 85 & 4,0 & 4,2 & 4,1 & 2,8 & 4,2 & 3,6 & 3,0 & 5,0 & 4,4 & 4,5 & 6,1 & 5,6 & 4,6 & 4,9 & 4,7 & 5,8 & 4,1 & 4,5 \\
\hline
\end{tabular}

Fonte: Elaboração da autora

Uma primeira constatação é a de que não se encontram ganhos significativos na esperança de vida à nascença, em qualquer das comunidades, ao longo de mais de um século. Partia-se em Santa Luzia de níveis extraordinariamente elevados de sobrevivência, não compatíveis com os comportamentos europeus da época ${ }^{11}$, mas também em Ponta Delgada os ganhos não foram muito expressivos ao longo dos períodos observados.

${ }^{11}$ LIVI-BACCI, 1987. 
A segunda constatação é a profunda diferença de comportamento entre a paróquia picoense e a florentina. Para os nascidos entre 1790 e 1829, esperava-se viver em Santa Luzia, mais 10 anos do que em Ponta Delgada. Ainda para os nascidos nos últimos 30 anos do século XIX essa diferença na esperança de vida ultrapassa os 8 anos.

Para os nascidos entre 1790 e 1829, enquanto em Santa Luzia as mulheres, ao nascer, tinham uma esperança de vida de 54 anos, em Ponta Delgada teriam de apenas 40. Ainda aos 65 anos, na paróquia picoense, as mulheres podiam esperar ainda viver mais 16 anos, enquanto na florentina, a esperança de vida se colocava nos 12 anos.

Reparamos ainda que, nesse primeiro período, de forma contrária a Santa Luzia, em Ponta Delgada os homens tinham uma esperança de vida ao nascer superior à das mulheres, situação que se vai inverter nas idades médias.

Considerando as gerações nascidas entre 1830 e 1869, não encontramos salto qualitativo em relação ao período anterior em Santa Luzia, agora com esperança de vida à nascença equivalente em homens e mulheres, mas em Ponta Delgada dá-se uma retração, mais acentuada no sexo masculino, a que não serão alheias as graves epidemias de 1833 e 1837, a afetar dominantemente crianças e jovens.

No terceiro período, gerações nascidas entre 1870 e 1899, notamos em Santa Luzia alguma melhoria nos valores, mas não muito significativa. A esperança de vida à nascença em Santa Luzia é afetada pela maior penalização pela morte de crianças abandonadas que estavam a ser criadas na freguesia.

Embora ainda longe dos níveis da paróquia picoense, nesse último período é mais nítida a melhoria na esperança de vida à nascença em Ponta Delgada, particularmente no caso das mulheres, que assumem agora clara vantagem em relação aos homens.

Outro indicador privilegiado, o cociente de mortalidade infantil, poderá esclarecer melhor as diferenças encontradas na esperança de vida à nascença.

Tabela 13. Cociente de mortalidade infantil (permilagem)

\begin{tabular}{c|c|c|c|c|c|c|c|c|c|c|c|c|c|c|c|c|c}
\hline \multicolumn{4}{c|}{$\begin{array}{c}\text { Gerações nascidas } \\
\text { entre 1790 e 1829 }\end{array}$} & \multicolumn{4}{c|}{$\begin{array}{c}\text { Gerações nascidas } \\
\text { entre 1830 e 1869 }\end{array}$} & \multicolumn{4}{c|}{$\begin{array}{c}\text { Gerações nascidas } \\
\text { entre 1870 e 1899 }\end{array}$} \\
\hline \multicolumn{2}{|c|}{ Santa Luzia } & \multicolumn{2}{c|}{ Ponta Delgada } & \multicolumn{3}{c|}{ Santa Luzia } & \multicolumn{2}{c|}{ Ponta Delgada } & \multicolumn{3}{c|}{ Santa Luzia } & \multicolumn{2}{c|}{ Ponta Delgada } \\
\hline M & F & MF & M & F & MF & M & F & MF & M & F & MF & M & F & MF & M & F & MF \\
\hline 156 & 161 & 159 & 239 & 241 & 241 & 169 & 177 & 173 & 269 & 229 & 251 & 193 & 179 & 186 & 279 & 263 & 271 \\
\hline
\end{tabular}

Fonte: Elaboração da autora

Como se verifica pelo quadro, as diferenças são também nítidas na mortalidade infantil da paróquia picoense e da florentina. Entre 1790 e 1829, em cada 1000 crianças nascidas morriam 159 em Santa Luzia e 241 em Ponta Delgada, antes de terem atingido 1 ano de idade. Nos períodos seguintes não há ganhos no que respeita à mortalidade infantil. Continuamos a apontar para a mortalidade mais gravosa das 
crianças nascidas fora do casamento e abandonadas, mas as crises de varíola, podem também ter afetado algumas dessas crianças, embora se saiba da sua relativa imunidade em período de lactação.

\subsection{Comportamentos comparados de mobilidade}

No acompanhamento dos percursos, para efeito da análise longitudinal da mortalidade, marcámos um fim de observação para os indivíduos nascidos nas comunidades em observação e que das mesmas se ausentaram. No entanto, o apuramento de resultados para as ausências definitivas da paróquia de origem não se encontra na mesma fase em todas as paróquias observadas. Como vimos, para as paróquias picoenses foram acompanhados os percursos dentro da própria ilha e na cidade da Horta, na ilha do Faial, o principal polo de atração urbana, além do cruzamento com o registo de passaportes. Assim, para Santa Luzia, a mobilidade estimada tem o sentido de longa distância, com eventual conhecimento dos destinos, tratando-se de emigração legal em período coberto pelos passaportes, enquanto para Ponta Delgada significa apenas que os indivíduos nascidos não faleceram na freguesia de origem.

Assim, para efeitos comparativos, ao estimar a percentagem de indivíduos das várias gerações que se ausentaram de forma definitiva da comunidade de origem, considerámos, para qualquer das paróquias, os efetivos iniciais de cada geração e os que lá não morreram, independentemente de sabermos qual o seu destino posterior.

Tabela 14. Percentagem de saídas em relação aos efetivos iniciais das gerações

\begin{tabular}{|c|c|c|c|c|c|c|c|c|c|c|c|c|}
\hline & \multicolumn{3}{|c|}{$1770-1819$} & \multicolumn{3}{|c|}{$1820-1849$} & \multicolumn{3}{|c|}{$1850-1879$} & \multicolumn{3}{|c|}{ 1880-1909 } \\
\hline & $\mathbf{H}$ & M & HM & $\mathbf{H}$ & M & HM & $\mathbf{H}$ & M & HM & H & M & HM \\
\hline Santa Luzia & 42 & 39 & 40 & 53 & 39 & 46 & 43 & 39 & 41 & 50 & 52 & 51 \\
\hline Ponta Delgada & 27 & 15 & 20 & 52 & 39 & 46 & 46 & 41 & 43 & 58 & 50 & 54 \\
\hline
\end{tabular}

Fonte: Elaboração da autora

Como se nota, a mobilidade apresenta-se como um fenómeno estrutural nestas comunidades açorianas, afetando tanto homens como mulheres. No entanto, para as gerações nascidas antes de 1820, ainda não afetadas pelo grande movimento de meados do século, há diferenças com algum significado entre as duas comunidades. $\mathrm{O}$ afastamento da paróquia de origem é bem mais frequente em Santa Luzia do que em Ponta Delgada, colocando-se nos $40 \%$ na primeira e apenas $20 \%$ na segunda, com comportamento diferencial, entre os sexos, bem mais significativo na paróquia florentina.

Quando passamos às primeiras gerações mais afetadas pela emigração massiva, as nascidas entre 1820 e 1849, os comportamentos aproximam-se nas duas comunidades, com mais de metade dos homens e perto de $40 \%$ das mulheres a não falecerem 
na terra em que haviam nascido. Para as gerações nascidas entre 1850 e 1879 dá-se alguma regressão nos movimentos de saída, que voltam a vincar-se para as gerações nascidas entre 1880 e 1909.

Importa verificar também os movimentos inversos de entrada de indivíduos de fora nas duas comunidades. Só podemos fazê-lo através das referências do registo de óbito dos mesmos, de forma desfasada dos movimentos de saídas, que avaliámos a partir de nascimentos. De qualquer forma, essa observação permite-nos uma comparação interessante.

Tabela 15. Percentagem de falecidos não naturais

\begin{tabular}{l|c|c}
\hline \multicolumn{1}{c|}{ Períodos } & Santa Luzia & Ponta Delgada \\
\hline Antes de 1800 & 12,0 & 4,4 \\
\hline $1800-1849$ & 8,3 & 8,7 \\
\hline $1850-1899$ & 5,4 & 14,7 \\
\hline $1900-1949$ & 9,6 & 18,0 \\
\hline $1950-1999$ & 10,2 & 16,9 \\
\hline Total & 8,9 & 9,4 \\
\hline
\end{tabular}

Fonte: Elaboração da autora

Se excetuarmos os falecidos antes de 1800, verificamos que Ponta Delgada foi mais atrativa para pessoas de fora, cativadas pela possibilidade de emprego nos trabalhos do campo, principalmente mulheres agricultoras, como comprovámos ao longo da reconstituição desenvolvida.

Não é depreciável também em Santa Luzia o peso de indivíduos não naturais que aí vieram a falecer, o que pode estar relacionado com a posse de vinhas e figueiras por parte de indivíduos de fora, particularmente da cidade da Horta que contratavam trabalhadores dentro e fora da freguesia.

A observação da origem dos falecidos não naturais pode dar-nos também indicações interessantes. Em Santa Luzia, $82 \%$ dos não naturais que aí faleceram eram de outras freguesias do Pico, começando pelas mais próximas. Em Ponta Delgada só $62 \%$ dos falecidos de fora eram da própria ilha, tendo vindo $18 \%$ do Corvo e $6 \%$ da ilha de S. Miguel.

\section{NOTA FINAL}

A espantosa sobrevivência, pelo menos desde o século XVIII, das gentes do Pico, da terra ardida que não dava pão, coloca muitas interrogações. Terá sido pelo clima ameno, sem frio ou calor intenso, mais seco do que em outras ilhas, pela diversidade alimentar, baseada no milho, mas com inhames, mais tarde com batatas brancas e batatas doces, pelo recurso frequente ao peixe, com carne escassa, muitas couves e 
frutas diversas, pela pureza das águas dos poços de maré ou das chuvas? Terá sido pelo obrigatório exercício físico diário de homens e mulheres, calcorreando caminhos e veredas para chegarem a distantes terras de cultivo ou pastagens, ou para descerem ao poço de maré buscar água ou subirem à encosta buscar lenha, terá sido pela cultura de respeito por cada um, pobre ou menos pobre, pela cultura de proteção à mulher mãe, à criança ou ao velho? Não sei responder. Limito-me a levantar a questão da resiliência do ser humano, muito a propósito na inquietude em que hoje vivemos.

\section{BIBLIOGRAFIA}

AMORIM, Maria Norberta (1992). Evolução Demográfica de três Paróquias do Sul do Pico: 1680-1980. Braga: Instituto de Ciências Sociais da Universidade do Minho.

AMORIM, Maria Norberta (2004). O Pico (séculos XVIII a XX). A Ilha açoriana mais poupada pela morte. «Revista de Demografía Histórica». 22:2, 53-84.

AMORIM, Maria Norberta (2008). O Pico. A abordagem de uma ilha. Madalena: Câmara Municipal da Madalena; Porto: CITCEM. Vol. I. As Famílias. Tomo VII. As Famílias de São Mateus nos finais do século XIX.

AMORIM, Maria Norberta (2011). O Pico. A Abordagem de uma Ilha. Madalena: Câmara Municipal da Madalena; Porto: CITCEM. Vol. I. As Famílias. Tomo X. As Famílias da Candelária nos finais do século XIX.

AMORIM, Maria Norberta (2016). O Pico. A Abordagem de uma ilha. Porto: CITCEM; Lajes do Pico: Desafios da Montanha. Vol. I. As Famílias. Tomo IX. As Famílias de Santa Luzia nos finais do século XIX.

AMORIM, Maria Norberta (2018). Uma aldeia no Oceano. As gentes do Corvo entre o século XVII e o XX. Porto: CITCEM.

AMORIM, Maria Norberta (2020). A Gripe Espanhola no quadro das epidemias históricas da ilha do Faial. In FERREIRA, Antero, coord. A Gripe Espanhola de 1918. Guimarães: Casa de Sarmento - Centro de Estudos do Património, Universidade do MINHO, pp. 45-65.

BANDEIRA, Mário Leston (1996). Demografia e Modernidade. Família e Transição Demográfica em Portugal. Lisboa: Imprensa Nacional-Casa da Moeda.

BARBOSA, Maria Hermínia Vieira; GODINHO, Anabela de Deus (2001). Crises de mortalidade em Portugal desde meados do século XVI até ao início do século XX. Guimarães: Núcleo de Estudos de População e Sociedade, Universidade do Minho. (Monografias; 10).

DEL PANTA, Lorenzo; LIVI-BACCI, Massimo (1977). Chronologie, Intensité et Diffusion des Crises de Mortalité en Italie: 1600-1850. «Population». 32e année. 1, 401-446.

LIVI-BACCI, Massimo (1987). Poblacion y alimentacion. Barcelona: Editorial Ariel.

MACEDO, António Lourenço da Silveira (1981). História das Quatro Ilhas que formam o Distrito da Horta. Angra do Heroísmo: Direção Regional dos Assuntos Culturais, volume III. Reimpressão fac-similada da edição de 1871.

SANTOS, Carlota (2008). Biodemografia do Concelho da Madalena. Madalena: Câmara Municipal da Madalena. 


\title{
O ALTO DOURO VINHATEIRO E PICO - QUINTAS E ADEGAS (SÉCULOS XIX-XX)*
}

\author{
CARLA SEQUEIRA** \\ PAULA MONTES LEAL****
}

\begin{abstract}
Resumo: No presente artigo, abordaremos a vinha e o vinho no Alto Douro Vinhateiro e na ilha do Pico numa perspectiva comparada, centrando a nossa análise nos séculos XIX e XX. Socorrendo-nos quer de bibliografia especializada, quer de documentação de arquivo (em particular para o Alto Douro Vinhateiro), procuraremos realçar as diferenças e semelhanças entre as duas regiões vitícolas Património Mundial, detendo-nos nos seguintes aspectos: estruturas sócio-económicas ligadas ao sector vitícola, respostas dadas às doenças da videira na segunda metade do século XIX, formas de armação de terreno e castas usadas na produção vitícola. Como exemplo prático de estudo, no caso particular do Alto Douro, apresentaremos as quintas do Bomfim, Zimbro e Senhora da Ribeira.
\end{abstract}

Palavras-chave: Alto Douro; Pico; Vinho e vinha; Quintas.

Abstract: In this article, we will analyze the vineyard and wine in Alto Douro and Pico Island in the 19th and 20th centuries, in a comparative perspective. Using either specialized bibliography or archive documentation (in particular for the Alto Douro wine region), we will highlight the differences and similarities between the two World Heritage wine regions, focusing on the following aspects: socio-economic structures of the wine sector, responses to vine diseases in the second half of the 19th century, forms of the land frame and grape varieties used in wine production. As a practical example of study, in the particular case of Alto Douro, we will present the Bomfim, Zimbro, and Senhora da Ribeira Estates.

Keywords: Upper Douro; Pico; Wine and vine; Estates.

\section{DAS ORIGENS À RECONVERSÃO}

Na região do Alto Douro, a mais antiga região demarcada e regulamentada do mundo, com predominância de solos de xisto, o cultivo da vinha remonta à época romana.

Os séculos XI a XIII registam uma particular expansão do vinhedo. E, logo no século XVII, negociantes ingleses, flamengos e holandeses estabelecem-se no Porto dedicando-se à exportação de vinhos do Douro.

Ao mesmo tempo que aumenta a exportação de vinhos para Inglaterra, começam os primeiros conflitos entre produtores e comerciantes, levando à constituição da Companhia Geral da Agricultura das Vinhas do Alto Douro por alvará régio, em 1756, acompanhada da demarcação da região produtora.

\footnotetext{
* As autoras não seguem o Acordo Ortográfico de 1990.

** Investigadora doutorada contratada FLUP/CITCEM. Email: carla.m.sequeira@sapo.pt.

${ }^{* * *}$ HUMANITATES; CITCEM. Email: paulamontesleal@gmail.com.
} 


\section{(5) \\ INSTITUIG A Ö \\ D A \\ COMPANHIA GERAL \\ DA AGRICULTURA DAS VINHAS \\ DO \\ ALTO DOURO.}

Fig. 1.

Capa do alvará régio de Instituição da Companhia Geral da Agricultura das Vinhas do Alto Douro, 1756 Fonte: Instituição da Companhia Geral [...], 1756

\section{LISBOA.}

Na Officina de MIGUELRODRIGUES, Impreffor do Eminentifimo Senhor Cardeal Patriarca.

M. DCC. LVI,

Cerca de um século mais tarde, o aparecimento das pragas da vinha conduziria a uma profunda transformação. Em 1872, num quadro de livre-cambismo para o sector do vinho do Porto, a filoxera havia-se já espalhado pela Região Duriense. O poder central procurou tomar medidas, nomeando uma comissão de estudo. As primeiras soluções de combate à praga no Alto Douro datam de 1876, passando pela utilização de sulfureto de carbono e plantação de vinhas com bacelos americanos. Nesta data, já muitas quintas e terras se encontravam à venda, e a crise instalou-se no sector, motivada pela queda abrupta dos quantitativos de produção.

As diversas soluções de combate à doença então adoptadas acabariam por conduzir a mudanças nas técnicas vitivinícolas, com o aperfeiçoamento dos processos de vinificação, novas técnicas de plantação e armação do terreno.

As pragas trouxeram também a crise social à Região Duriense. «A redução da produção e o investimento na reconversão acarretaram o endividamento e a miséria. As propriedades desvalorizaram. ${ }^{1}{ }^{1}$ À semelhança do que se verificaria no Pico, «acelerou-se a transferência de propriedade» ${ }^{2}$. Em simultâneo, assistir-se-ia a uma

\footnotetext{
${ }^{1}$ SEQUEIRA, 2011: 77.

${ }^{2}$ SEQUEIRA, 2011: 77.
} 
alteração na geografia do vinhedo, com a valorização dos vinhos produzidos no Douro Superior.

Seria nesta época que a Silva e Cosens ${ }^{3}$ compraria três quintas emblemáticas da Região, todas elas afectadas pela filoxera e posteriormente replantadas com recurso a enxertia de vinha americana nas «mais conceituadas castas durienses» 4 .

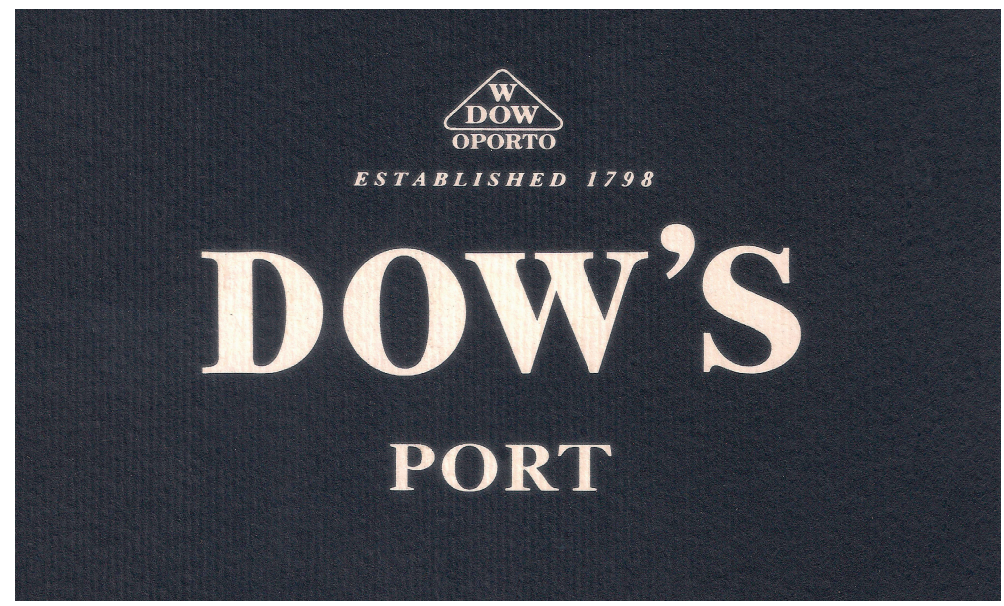

Fig. 2.

Logótipo Dow's Fonte: Symington Family Archives

A primeira a ser adquirida terá sido, em data anterior a $1886^{5}$, a Quinta do Zimbro, situada na sub-região do Cima Corgo; desde então, tem sido produtora dos vinhos da marca Dow's. Em 1896 seria comprada a Quinta do Bomfim, situada também na sub-região do Cima Corgo, e igualmente produtora de vinhos Dow's. Por fim, a Quinta da Senhora da Ribeira, localizada na sub-região do Douro Superior, seria adquirida em $1890^{6}$.

Quanto aos Açores, a introdução da vinha no arquipélago ocorreu no século XV, começando pelas ilhas de S. Miguel e Terceira. No caso particular da ilha do Pico, a casta introduzida, nos primórdios da colonização, foi a verdelho, com expansão rápida e abundante, abrangendo, «sobretudo, a parte da ilha virada para o Faial, concentrada esmagadoramente no concelho da Madalena, entre as freguesias da

\footnotetext{
${ }^{3}$ Empresa fundada em 1798 por Bruno Evaristo Ferreira da Silva, um comerciante portuense que se instalou em Londres, de onde importava vinho e outras mercadorias de Portugal, pondo fim ao monopólio até então praticamente detido por mercadores ingleses (cf. GRÉMIO DOS EXPORTADORES DE VINHO DO PORTO, 1948). Após várias parcerias empresariais e familiares, a empresa acabaria por pertencer ao grupo Symington, em 1961 (cf. LAGE, 2018: 369-371). ${ }^{4}$ MONTEIRO, 1911: 80.

${ }^{5}$ LAGE, 2018: 340.

${ }^{6}$ Cf. MAYSON, [1998]. Contudo, os documentos da Silva e Cosens relativamente a esta quinta começam em data anterior, podendo ler-se que o dono da quinta em 1888 é Francisco Pereira (Cf. Symington Family Archives, 1888-1891). Neste copiador é possível verificar que as três quintas eram já exploradas pela Silva e Cosens se não antes, pelo menos em 1888, portanto antes da data da compra do Bomfim (1896) e da Senhora da Ribeira (1890).
} 
Candelária, São Mateus e Bandeiras» ${ }^{7}$. Ao longo dos séculos XVI e XVII, o Pico apresentava-se coberto de vinhedos, em particular nas freguesias de Santa Bárbara, Santa Cruz das Ribeiras e na vila de S. Roque do Pico. Em finais do século XVII, o concelho da Madalena assumiria preponderância vitícola, em particular nas freguesias da Candelária e Bandeiras.

Fig. 3.

Paisagem protegida da cultura da vinha, no Lajido da Criação Velha. Fonte: Paula Montes Leal, 2019

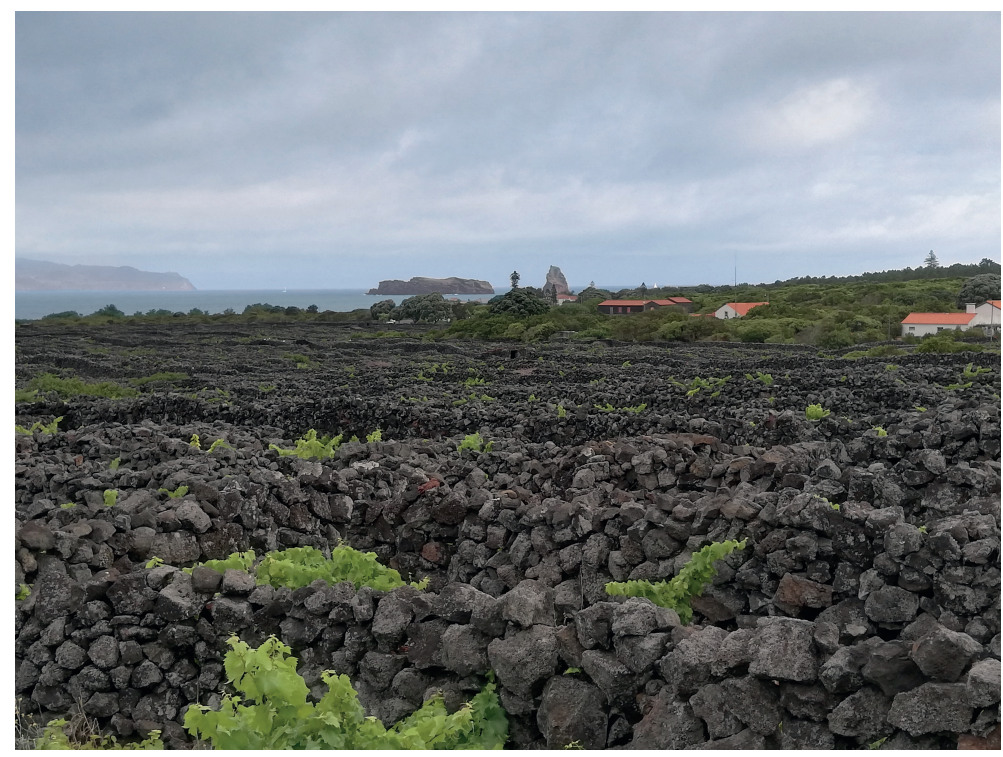

O tipo de solo, basáltico, confere «condições extremamente favoráveis para a boa maturação das uvas»" : «o Sol ia maturando os cachos que de noite recebiam o bafo quente que o basalto conservara, sazonando completamente» ${ }^{9}$. E assim as populações locais se dedicaram a «meter plantas de vinha nas fissuras do manto requeimado que recobre toda a encosta ocidental da Ilha do Pico» ${ }^{10}$.

Em meados do século XVII, a vinha começou a adquirir um progressivo valor comercial superando «em muito a produção vinícola das outras parcelas insulares» ${ }^{11}$.

A produção vitícola e a diversidade ampelográfica do Pico seriam prejudicadas com o oídio e a filoxera, na segunda metade do século XIX, levando ao desaparecimento de castas como as castas verdelho silvestre, bastardo branco e galega ${ }^{12}$. As condições geológicas e climáticas do arquipélago não ajudavam a que os produto-

\footnotetext{
${ }^{7}$ SOUSA, 2004: 135.

${ }^{8}$ SILVA, 1951: 46.

${ }^{9}$ DUARTE JÚNIOR, 2004: 48.

${ }^{10}$ DUARTE JÚNIOR, 2004: 27.

${ }^{11}$ COSTA, 1995: 90.

${ }^{12}$ Cf. SILVA, 1951: 47.
} 
res investissem em factores tecnológicos como, por exemplo, o uso de sulfatos para combate às pragas por se tratar de uma técnica cara e de uso repetido, no caso dos Açores, devido às chuvas constantes.

A verdelho, casta mais atacada pelas pragas, foi substituída pela Isabela, introduzida por Manuel Maria de Terra Brum ${ }^{13}$, um dos maiores viticultores do Pico. Esta casta americana — produtor directo - tinha grande resistência às pragas, rusticidade, vigor vegetativo e produtividade, pelo que rapidamente se estendeu a toda a ilha.

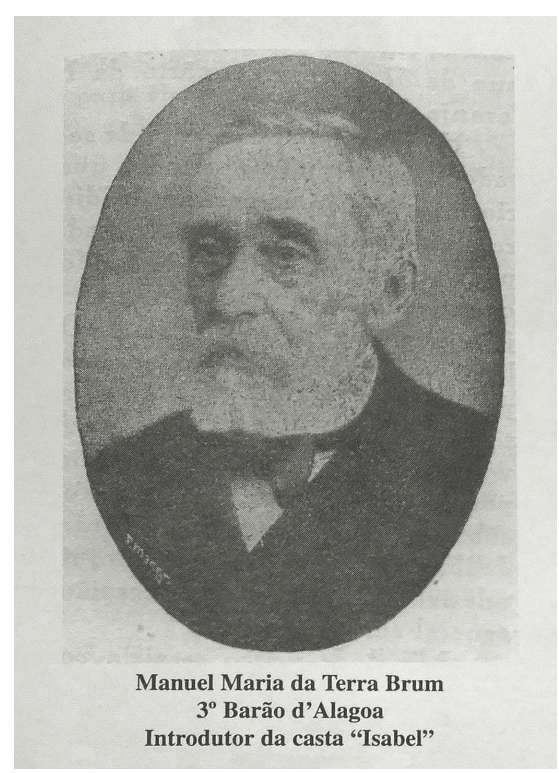

Fig. 4. Manuel Maria de Terra Brum, introdutor da casta Isabela na ilha do Pico Fonte: DUARTE JÚNIOR, 2004: 187

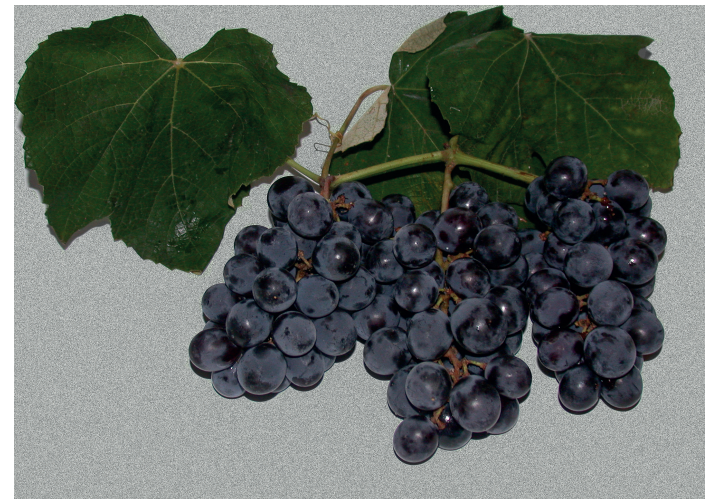

Fig. 5. Casta Isabela Fonte: Foto MM, $2005^{14}$

Seguir-se-ia um período de completa reconversão da viticultura açoriana, marcado por um novo posicionamento na economia agrícola do arquipélago e o quase desaparecimento das castas europeias «menos resistentes que foram sendo substituídas por castas americanas de inferior qualidade» ${ }^{15}$.

Em consequência do processo de reconversão, a área de vinha aumentaria, registando 3022 hectares em 1903, nas ilhas do Faial, Pico, Flores e Corvo, mas o vinho produzido era diferente e de inferior qualidade - o chamado vinho de cheiro. Por

\footnotetext{
${ }^{13}$ DUARTE JÚNIOR, 2004: 187. Na página da Comissão Vitivinícola Regional dos Açores (https://www.azoreanwines. com/historia) refere-se que o introdutor da casta Isabela foi António Borges da Câmara Medeiros (14-6-1812 18-3-1879; marquês da Praia e Monforte, grande proprietário, negociante, político açoriano), trazendo-a para a ilha de S. Miguel em 1853-54.

${ }^{14}$ Disponível em <https://commons.wikimedia.org/wiki/File:UvaFragola.jpg>.

15 SOUSA, 2004: 150.
} 


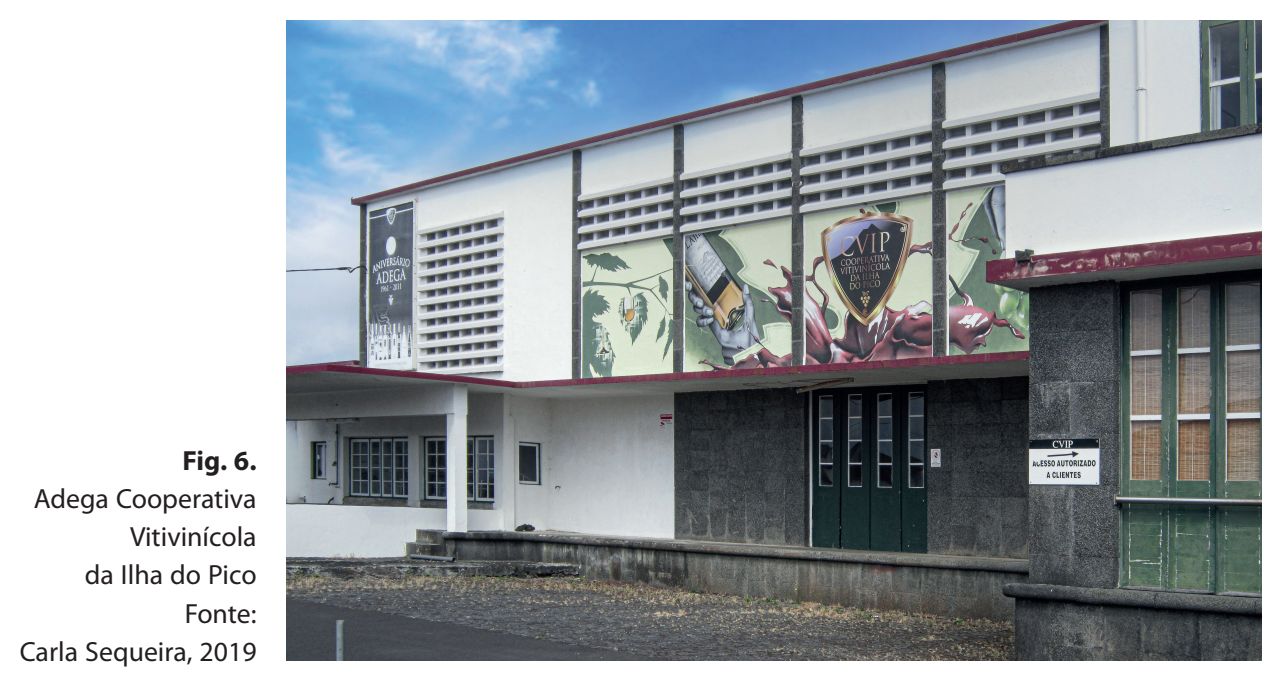

outro lado, assistia-se à ausência de critério definido para a escolha das castas, a uma produção fraccionada e vinificação de forma empírica em adegas rudimentares. Esta situação apenas começaria a inverter-se com a constituição da Adega Cooperativa Vitivinícola da Ilha do Pico, em 1951, no sentido da reorganização do sector através da fixação de um único tipo de vinho licoroso aperitivo e recuperação da «fama do antigo e esquecido verdelho» ${ }^{16}$.

\section{FORMAS DE ARMAÇÃO DE TERRENO E CASTAS}

Na Região Demarcada do Douro, conforme refere Natália Fauvrelle ${ }^{17}$, a evolução das técnicas agrícolas, as doenças da vinha e a falta de mão-de-obra conduziram à alteração nas formas de armação do terreno e de condução das vinhas.

No período pré-filoxérico, a armação do terreno fazia-se em socalcos e a condução da vinha era feita com recurso a tutores de madeira; os muros de pedra estavam mais ou menos afastados conforme o declive do terreno. Após a filoxera, as paredes dos muros tornaram-se mais altas e de traçados rectilíneos. Assistiu-se, então, a uma «alteração radical do modo de armar o terreno» também pelo facto de as castas americanas exigirem «surribas mais profundas». Introduziu-se também a prática de embardar a videira com esteios de lousa e arames de zinco. Mais recentemente (a partir da década de 1970), a necessidade de mecanizar os trabalhos da vinha levou à substituição dos muros por taludes e à construção de patamares acompanhando as curvas de nível das encostas. Viria também a ser ensaiado um novo modelo, de vinha ao alto, nas encostas com declive inferior a $40 \%$.

\footnotetext{
16 SOUSA, 2004: 215. Era também objectivo, a prazo, a demarcação da região vinícola e o «reconhecimento oficial da marca de garantia do vinho». SILVA, 1951: 57.

${ }^{17}$ Cf. FAUVRELLE, 2006: 181-239.
} 


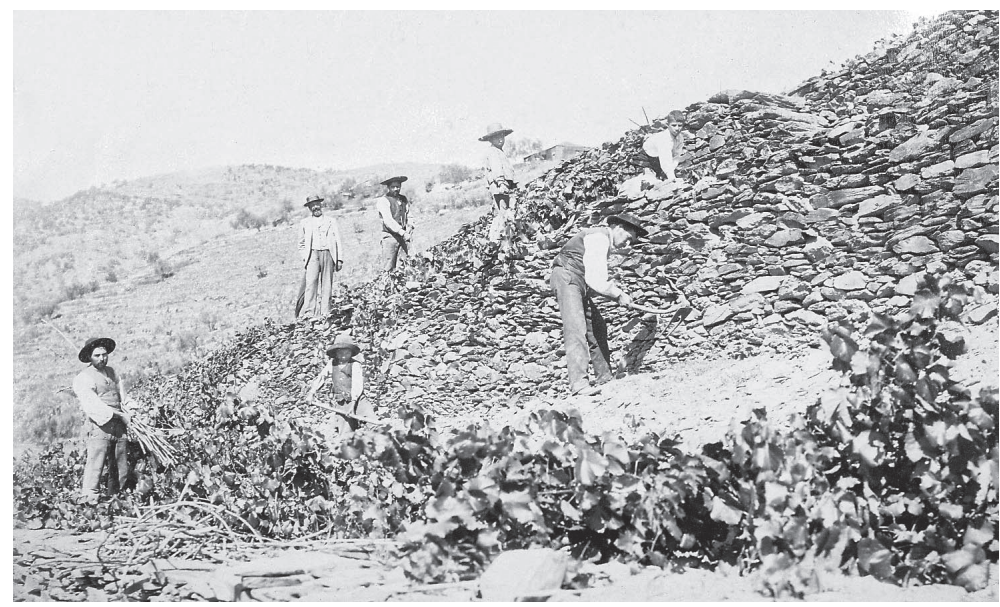

Fig. 7.

Trabalhos da vinha na Quinta do Bomfim (início do século XX) Fonte: Col. Symington Family Archives

Fig. 8.

Embardamento da vinha com estacas de lousa e arames de zinco

Fonte: Foto Alvão, c. 1935. Col. Instituto dos Vinhos do Douro e Porto

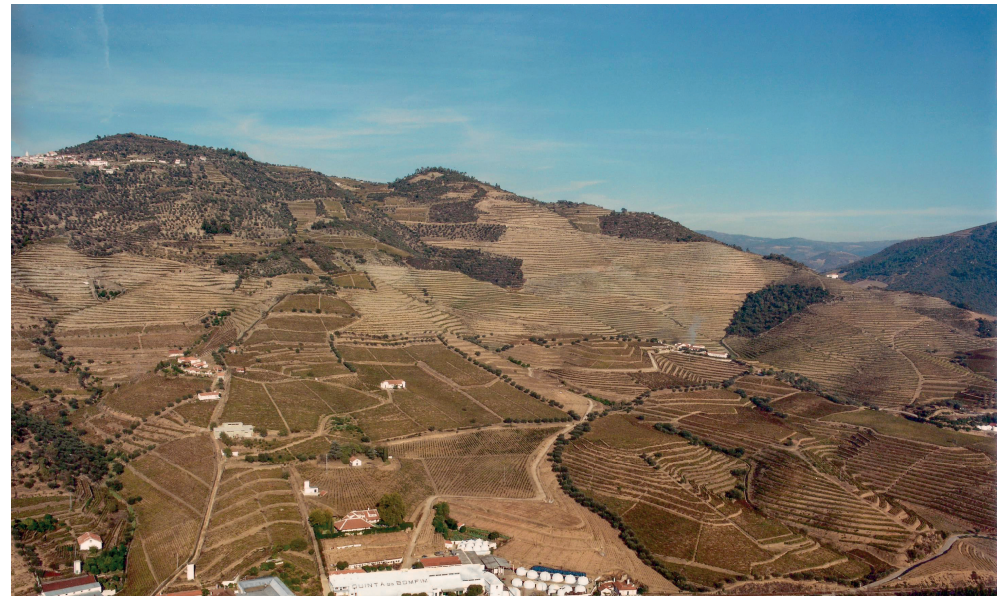

Fig. 9.

Vista aérea da

Quinta do Bomfim (século XXI)

Fonte: Autor não identificado. Symington Family Archives 
A variedade ampelográfica da Região do Douro mostrou-se sempre diferente em relação à ilha do Pico, embora seja de notar a existência de algumas castas em comum.

Em finais do século XVIII, estavam identificadas 67 castas na zona de Lamego (38 tintas, 29 brancas). Desde logo, contudo, a viticultura duriense se preocupou com a «selecção das castas que melhor se adaptassem à produção de vinho do Porto» ${ }^{18}$, «de acordo com os tipos de terrenos e os vinhos» ${ }^{19}$ que se pretendia produzir.

Em meados do terceiro quartel do século XIX, entravam na composição do vinho do Alto Douro cerca de vinte variedades de uva, entre as quais as castas tintas alvarelhão, bastardo, casculho, cornifesto (uma das boas castas tintas do Douro, bastante comum no Cima Corgo e Douro Superior; resistente ao oídio), mourisco tinto, moreto (casta predominante no Alentejo mas também muito apreciada no Alto Douro), sousão, tinta amarela, tinta-carvalha, tinta Francisca ou francesa, tinta lameira, rufete, tinto cão e touriga; entre as brancas, côdega ou malvasia grossa, diagalves, gouveio ou verdelho, malvasia e moscatel (incluindo a moscatel de Jesus).

A de maior reputação era a touriga. A tinta Francisca era igualmente muito apreciada, sendo cultivada nas principais quintas do Cima Corgo. «O sousão, a única das restantes variedades de uva tinta do Alto Douro que mereça especial referência, foi trazida das margens do rio Lima, nos princípios do século [século XVIII]» ${ }^{20}$, tendo-se tornado predominante em Vila Flor, Alijó e Sabrosa.

Nas três quintas adquiridas pela Silva e Cosens, em 1910 plantavam-se, entre outras, a tinta Francisca, tinta amarela, casculho, cornifesto e moreto ${ }^{21}$. Nos inícios da década de 1920, as castas eram as mesmas, à excepção da casculho substituída pela rufete (casta tinta, também conhecida como tinta pinheira, usada na região da Beira Baixa, mas igualmente no Douro, primeiramente nos concelhos de Vila Nova de Foz Côa e Figueira de Castelo Rodrigo), a que se acrescentava também a côdega (cultivada em larga escala no Cima Corgo) ${ }^{22}$.

Tal como no Alto Douro, no Pico revelar-se-ia «impressionante o esforço sobre-humano que as populações locais foram capazes de realizar, ao longo de séculos, para transformar terrenos aparentemente improdutivos em torrões úberes, ricos e muito valorizados. Foi assim criada uma nova área de paisagem de características únicas» ${ }^{23}$.

Para protecção dos ventos fortes «provenientes de todos os quadrantes e do rossio do mar, foram elevados muros de abrigo com a pedra basáltica retirada do próprio local, que deram origem a uma sequência de rectângulos, os característicos "currais" ${ }^{24}$.

\footnotetext{
${ }^{18}$ PEREIRA, 1991: 83 e 85.

${ }^{19}$ PEREIRA, 1991: 85.

${ }^{20}$ PEREIRA, 1947: 60-63.

${ }^{21}$ Symington Family Archives, 1908-1919.

${ }^{22}$ Symington Family Archives, 1918-1922.

${ }^{23}$ SOUSA, 2004: 217.

${ }^{24}$ SILVA, CARQUEIJEIRO, coord., 2004: 109.
} 


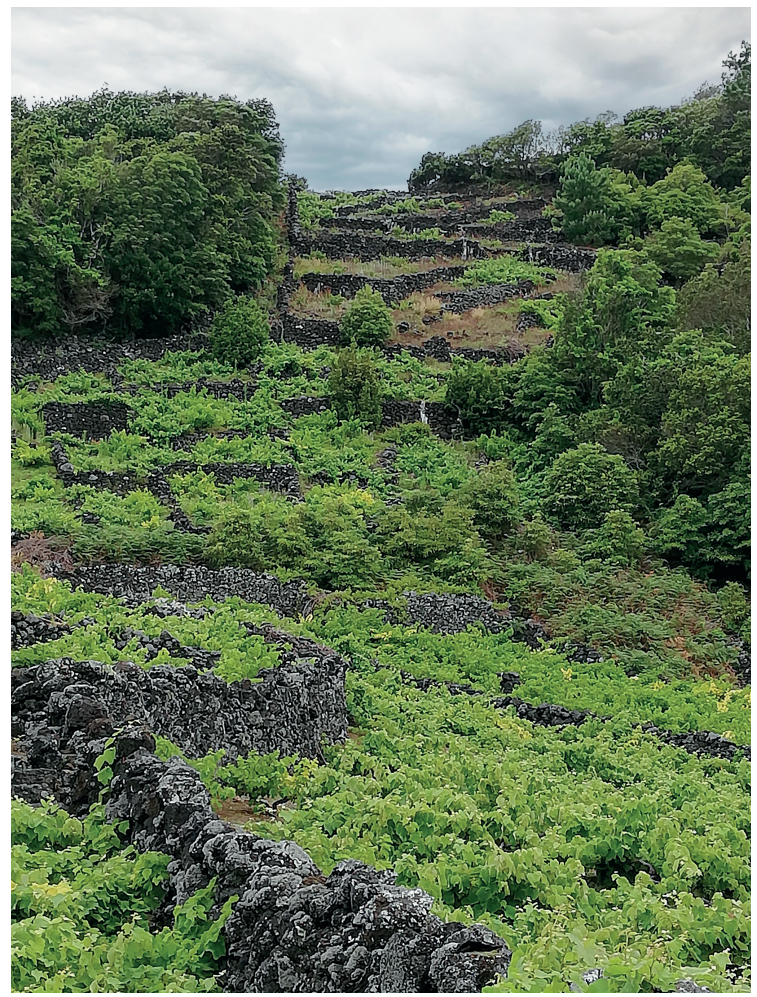

Fig. 10.

Paisagem da Cultura da Vinha da Illha do Pico

Fonte: Paula Montes Leal, 2019

Em termos de técnica vitícola, «dava-se ao solo apenas uma raspagem, não se atavam nem estacavam as videiras, aplicava-se raramente o sulfato e o enxofre, e fazia-se a erguida na época da maturação» ${ }^{25}$.

Quanto ao leque ampelográfico da ilha do Pico, em 1822, o visconde de Vilarinho de S. Romão ${ }^{26}$ referia as castas alicante, boal, galego, verdelho, verdelho valente, terrantez do monte (branco) e bastardo (tinto). Em 1884, as castas cultivadas eram a casta verdelho, "que tomou logo foros de casta-mãe, pela sua elevada qualidade», verdelho silvestre, boal, bastardo, terrantez, e também castas de uvas de mesa, como moscatel branco e roxo, e dedo de dama. Existiam ainda outras variedades: moscatel de Jesus, diagalves, uva do monte, ferral, entre outras, usadas para completar o lote na feitura do vinho e também como uvas de mesa.

A base de produção era a casta verdelho, misturada com as outras «em partes proporcionais» ${ }^{27}$.

\footnotetext{
25 SOUSA, 2004: 206.

26 GIRÃO, 1822.

27 SILVA, CARQUEIJEIRO, coord., 2004: 133.
} 


\section{QUINTAS E ADEGAS}

No Alto Douro, «a unidade de exploração agrícola é por excelência a quinta, modelo de estrutura agrária regional que assume grandes proporções e cuja composição permitiu a gestão da actividade vitivinícola de forma autónoma ao longo dos tempos» ${ }^{28}$. Em paralelo, «pequenas parcelas de terreno são trabalhadas pelos habitantes dos povoados» ${ }^{29}$.

A quinta duriense é constituída por uma «grande diversidade de construções, rodeadas de terrenos de cultivo e monte» ${ }^{30}$. Ao centro, as principais estruturas de habitação e de produção, «espaços de maiores ou menores dimensões, directamente associados à actividade vinhateira ou vocacionados para outras culturas ${ }^{31}$.

Fig. 11.

Quinta do Bomfim no início do século $X X$ Fonte: Postal Silva e Cosens, c. 1910. Symington Family Archives

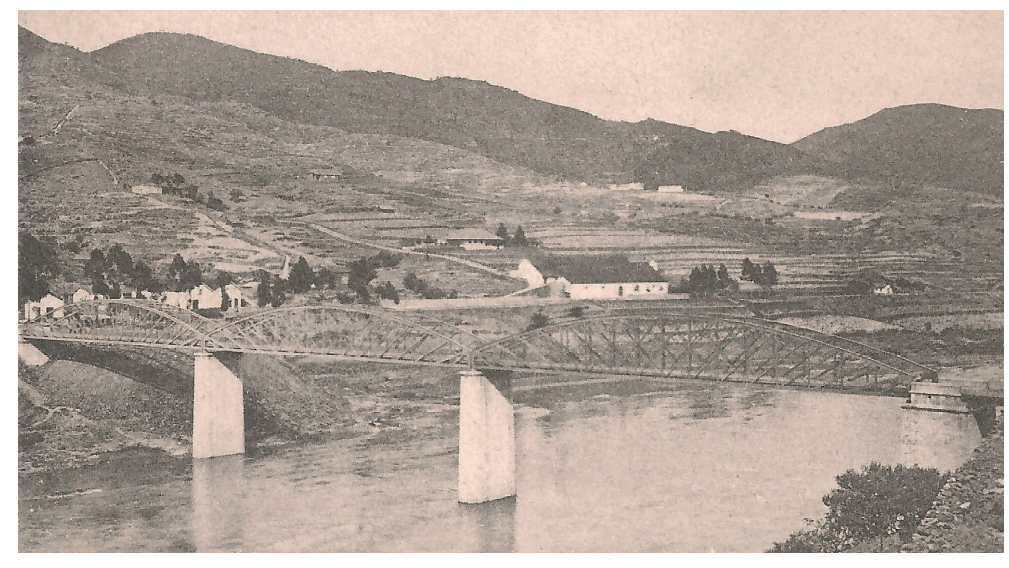

Fig. 12.

Quinta da Senhora da Ribeira no início do século $X X$ Fonte: Foto Emílio Biel, c. 1910 apud MONTEIRO, 1911: 8

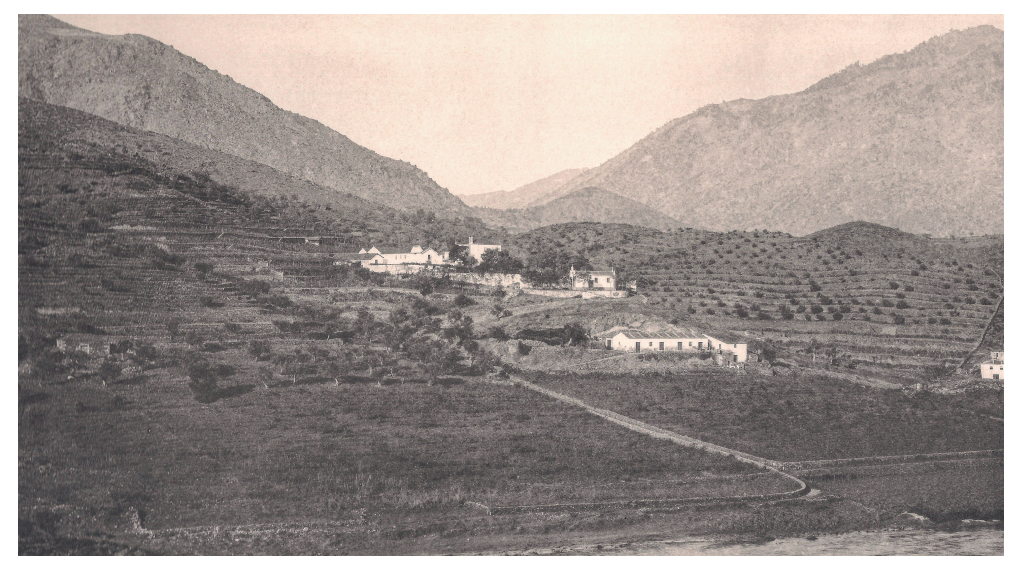

\footnotetext{
${ }^{28}$ FAUVRELLE, 2006: 182.

${ }^{29}$ FAUVRELLE, 2006: 182.

${ }^{30}$ FAUVRELLE, 2006: 182.

${ }^{31}$ FAUVRELLE, 2006: 182.
} 
A casa de habitação do proprietário, habitada principalmente durante as férias ou nas vindimas, «é quase sempre a maior construção da quinta» ${ }^{32}$. Apresenta entre dois e três pisos ${ }^{33}$.

Em termos funcionais, além da habitação (nos pisos superiores), a casa albergava também estruturas de produção (nos pisos térreos), destacando-se os armazéns de vinho que, tirando «o máximo proveito da inclinação do terreno» surgiam «encaixados num socalco de modo a poder ter nas traseiras uma outra casa, onde se coloca[va]m os lagares de modo a que o vinho escorr[esse] pela força da gravidade através de caleiras de granito até aos tonéis, depositados no andar de baixo. Esta situação verificava-se nas casas mais antigas do Douro» ${ }^{34}$. Por exemplo, na Quinta do Bomfim e na Quinta da Senhora da Ribeira, os armazéns comunicavam com os lagares, situados em plano superior ${ }^{35}$.

Segundo refere Natália Fauvrelle, «a partir de finais do século XVIII estes dois espaços [lagares e adega] ganharam maior autonomia, constituindo um edifício à parte da casa de habitação» ${ }^{36}$. Como exemplo, a Quinta da Senhora da Ribeira apresentava, além da casa de habitação do proprietário, casas do pessoal e três lagares independentes ${ }^{37}$.

Além da casa de habitação e das estruturas ligadas à produção vinícola, as quintas do Douro apresentavam outras estruturas arquitectónicas: a casa do caseiro (junto da casa principal), bem como outras «estruturas de apoio» à actividade da quinta, entre as quais «cavalariças, tulhas, pocilgas, galinheiros, frasqueiras ou pombais» ${ }^{38}$.

Já no Pico, em termos sócioeconómicos, a viticultura ficou marcada pela presença significativa das elites entre os produtores, que ali mantinham feitores e casas de Verão, com o «domínio das casas faialenses na cultura da vinha da mais importante área da ilha do Pico a ela dedicada [Madalena]» ${ }^{39}$. Os picoenses detinham uma pequena percentagem de vinhas, significando uma produção pouco superior a $25 \%$.

Toda a zona ocidental da ilha do Pico pertencia «às diversas casas senhoriais implantadas na Horta ${ }^{40}$, contando-se, entre estas, as famílias Arriaga, Brum, Cunha, Silveira, Terra, Goulart de Medeiros, Carvalho de Medeiros (primos), Dabney, Furtado, Lemos, Melo e Bettencourt.

Em finais do século XIX, em consequência das pragas da videira, assistir-se-ia à transferência de propriedade: «desencorajados, muitos dos proprietários faialenses

\footnotetext{
32 FAUVRELLE,1999: 9.

${ }^{33}$ FAUVRELLE, 1999: 29.

${ }^{34}$ FERREIRA, 1999: 51.

${ }^{35}$ Cf. MONTEIRO, 1911: 79.

${ }^{36}$ FAUVRELLE, 1999: 52.

${ }^{37}$ Cf. MONTEIRO, 1911: 79.

${ }^{38}$ FAUVRELLE, 1999: 60.

${ }^{39}$ COSTA, 2004: 130.

${ }^{40}$ DUARTE JÚNIOR, 2004: 88.
} 
desfizeram-se das vinhas e também de residências e outros edifícios de apoio à actividade vinícola $»^{41}$, vendendo-as aos feitores. Em 1893, em 46 viticultores recenseados no concelho da Madalena, apenas 22 habitavam na Horta. «Os restantes eram já naturais» da ilha do Pico e «residentes da Madalena, Bandeiras e Criação Velha» ${ }^{42}$.

Apesar da transferência de propriedade citada, Pico e Faial continuaram a «viver numa espécie de complementaridade económica» ${ }^{43}$. O Faial enviava para o Pico os cereais de que a ilha carecia (milho e trigo) e o Pico remetia gado, lenha, carvão, frutas e vinho. Além disso, «no caso do Pico as poucas evidências parecem apontar para de um lado os grandes vinhateiros, morgados do Faial, que vendiam a produção em bruto, e do outro os negociantes da Horta que os preparavam e exportavam» ${ }^{44}$.

Fig. 13.

Pastagem de altitude para gado bovino na Reserva Natural da Montanha do Pico Fonte: Paula Montes Leal, 2019

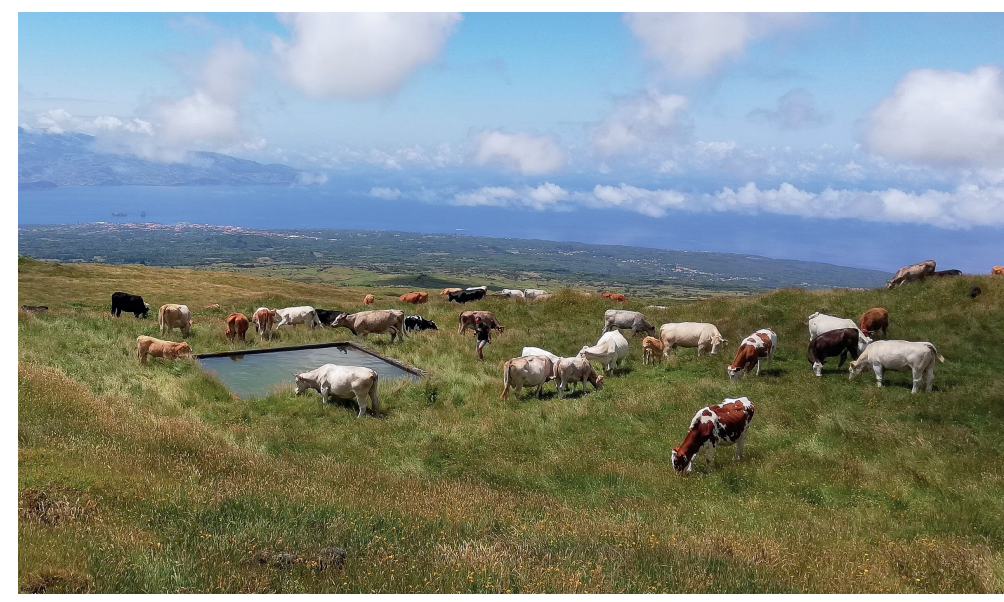

Era na ilha do Faial, mais concretamente, na cidade da Horta, que se concentravam as empresas, sobretudo inglesas, que se dedicavam à exportação de vinho, sob a denominação de «Faial» ${ }^{45}$. Desde, pelo menos, o século XVIII, «em toda a América de feição inglesa, os bons vinhos do Pico» eram "chamados "Fayal Wines"» ${ }^{46}$.

A casa mais importante no comércio de vinhos no Faial era a Scott Idle e Sobradello, firma inglesa que se fixou no Faial no final do século XVIII. Segundo Ricardo Madruga da Costa, e a título de exemplo, no ano de 1805, esta casa exportou 441 pipas de vinho «da maior regulação»e 468 pipas de vinho comum ${ }^{47}$.

\footnotetext{
${ }^{41}$ DUARTE JÚNIOR, 2004: 78.

${ }^{42}$ SOUSA, 2004: 204.

${ }^{43}$ SOUSA, 2004: 135.

${ }^{44}$ SOUSA, 2004: 137.

${ }^{45}$ SOUSA, 2004: 136.

${ }^{46}$ DUARTE JÚNIOR, 2004: 56.

${ }^{47}$ COSTA, 2005: 146.
} 


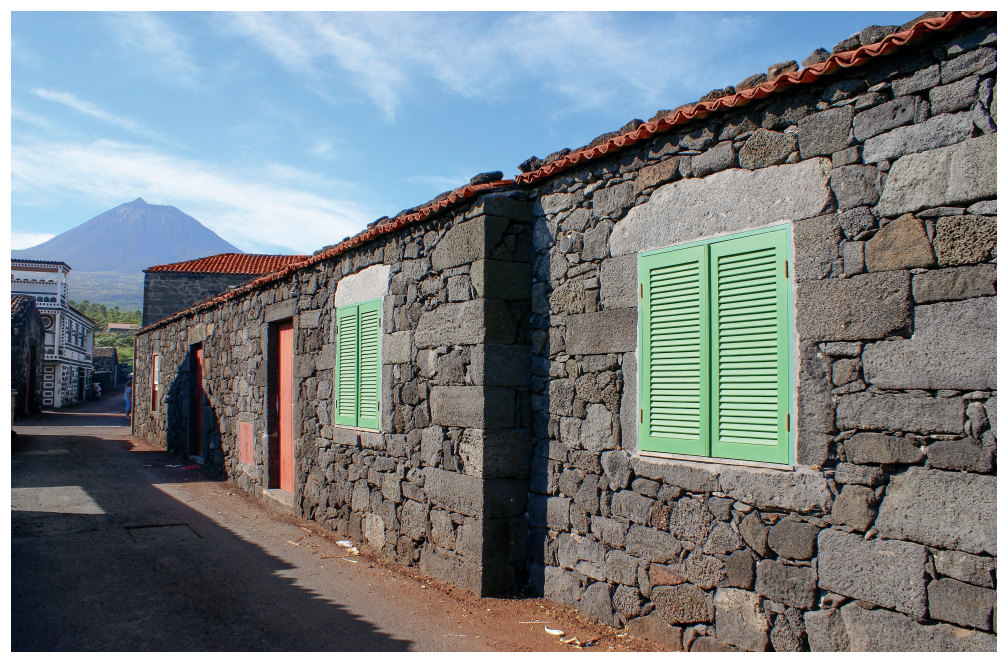

Fig. 14.

Exemplo de casa/adega tradicional da Paisagem Protegida de Interesse Regional da Cultura da Vinha da Ilha do Pico (Lagido de Santa Luzia, concelho de S. Roque do Pico. Fonte: Foto de José Luís Ávila Silveira/ Pedro Noronha e Costa, $2010^{48}$

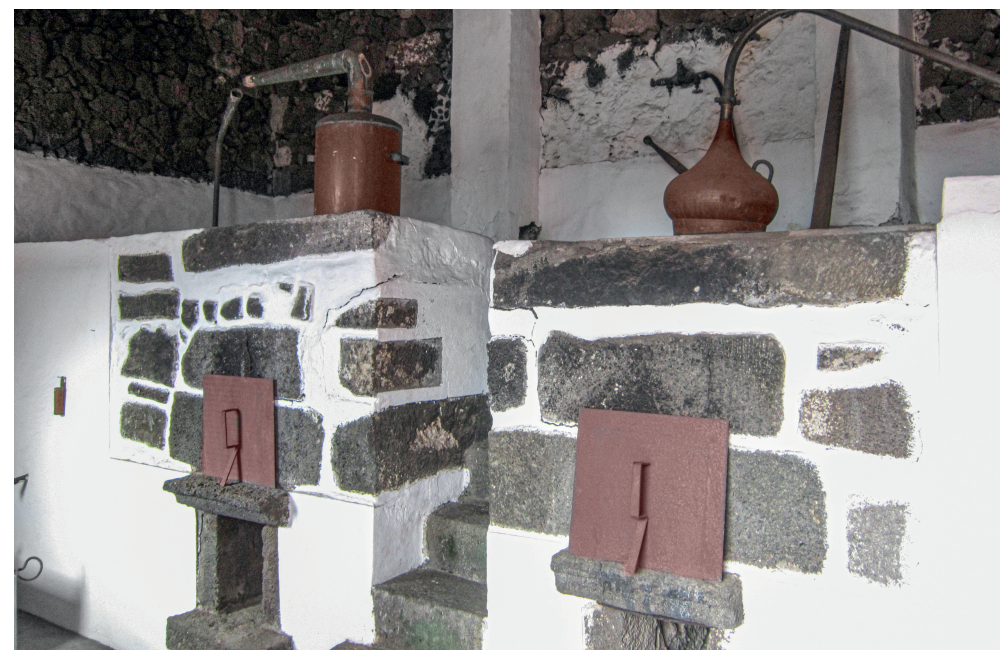

Fig. 15.

Alambique. Museu do Pico - Pólo do Museu do Vinho Fonte: Carla Sequeira, 2019

Quanto às tipologias arquitectónicas ligadas à produção vitícola, temos as «casas solarengas das famílias abastadas e as demais construções de apoio: adegas, arrecadações, lagares, alambiques e, em muitos casos, acomodações para os jornaleiros que se deslocavam de longe, principalmente para as vindimas» ${ }^{49}$. De registar ainda os núcleos costeiros, organizados em torno das casas senhoriais e com um complexo de produção constituído por alambique, armazém e adegas.

As adegas são edifícios de pedra negra, de relativamente pequena dimensão, de planta rectangular e com um ou dois pisos. Na sua maioria, são edifícios que servem

\footnotetext{
${ }^{48}$ Disponível em <https://commons.wikimedia.org $>$.

${ }^{49}$ COSTA, 2005: 28.
} 
de adega, lagar (rés-do-chão), e simultaneamente de habitação sazonal (primeiro piso) durante o Verão. Os alambiques são estruturas usadas para produção de aguardente de vinho ou de figo. Podem ser «edifícios autónomos com um só piso ou podem possuir anexos, tais como poços de maré e cisternas para fornecimento de água necessária para o seu funcionamento, e armazéns com barricas e balseiros onde se armazenam as frutas em fermentação para depois serem "queimadas". Os armazéns são muito semelhantes aos edifícios já descritos, diferindo apenas na sua volumetria: edifícios mais compridos e com poucas aberturas» ${ }^{50}$. Temos, como exemplos, os núcleos dos Arcos, Cachorro e Lajido (freguesia de Santa Luzia, concelho de S. Roque do Pico), no centro do qual fica o Solar dos Salgueiros, datado do século XVIII e rodeado por adega, casas de arrumos e poço de maré51.

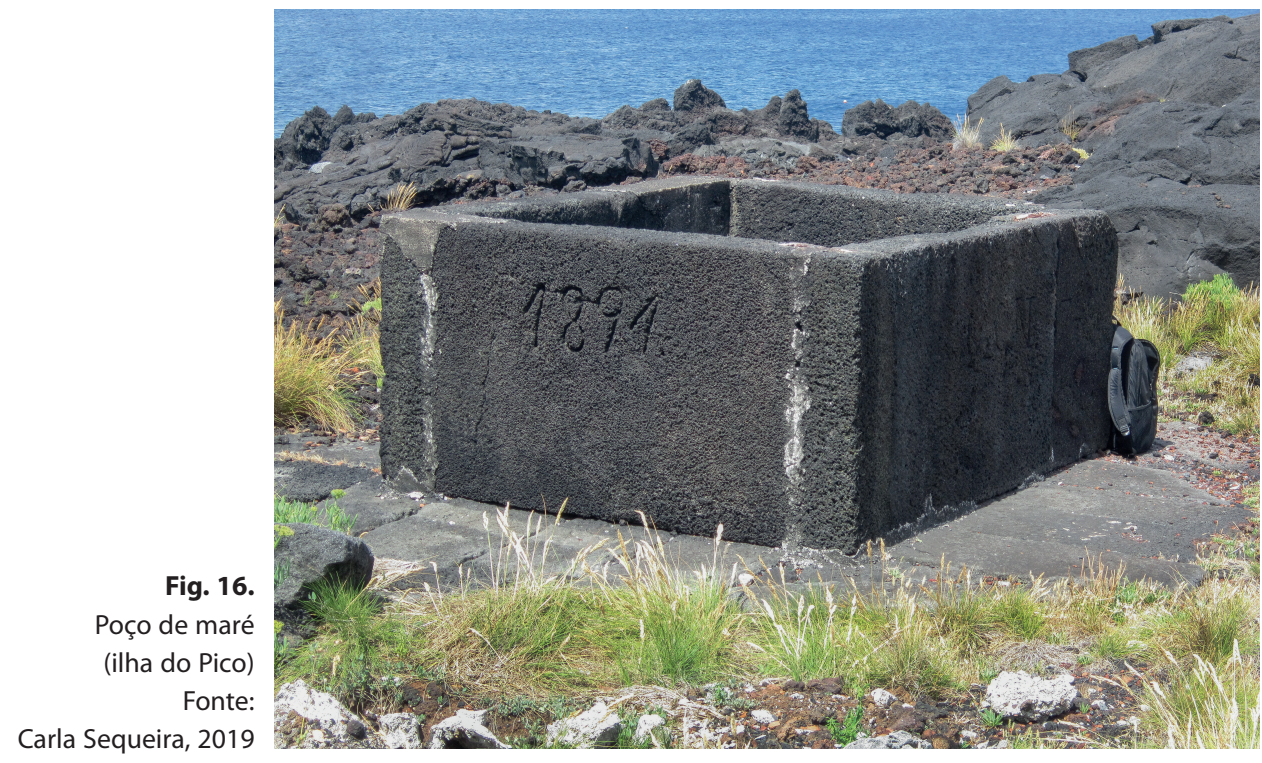

As casas solarengas, como por exemplo o Solar dos Salemas (com data de construção inicial remontando aos séculos XVIII-XIX ${ }^{52}$ ), construídas normalmente em «extensas propriedades vitivinícolas, de chão lajido, junto ao litoral», encontram-se implantadas num complexo constituído por diversas estruturas complementares entre si: «um edifício principal, destinado à habitação de veraneio, constituído por dois

\footnotetext{
${ }^{50}$ SILVA, CARQUEIJEIRO, coord., 2004: 73.

${ }^{51}$ No seu poço de maré pode ler-se a inscrição «1756». Além de estar classificado como Valor Concelhio, o Solar também está integrado na Paisagem Protegida de Interesse Regional da Cultura da Vinha da Ilha do Pico, criada pelo Decreto Legislativo Regional n. ${ }^{\circ}$ 12/96/A, de 27 de Junho. AÇORES. Assembleia Legislativa Regional, 1996.

${ }^{52}$ Cf. <https://www.iac-azores.org/iac2018/projetos/IPIA/pico/madalena_fichas/61_11_72.html>.
} 
pisos, sendo o primeiro destinado à actividade vitícola e o segundo à habitação. Sendo a planta em L, remete para um segundo edifício onde ficaria localizada a cozinha, forno e copa». O acesso à casa faz-se por uma escadaria em basalto, «colocada num dos topos do edifício principal, coberto por alpendre»; edifício de um piso, «destinado ao apoio da actividade vitivinícola», com adega, lagar e alambiques. «Normalmente, possuem um poço de maré ou cisterna, jardim e árvores.» ${ }^{53}$ Algumas destas casas teriam capela.

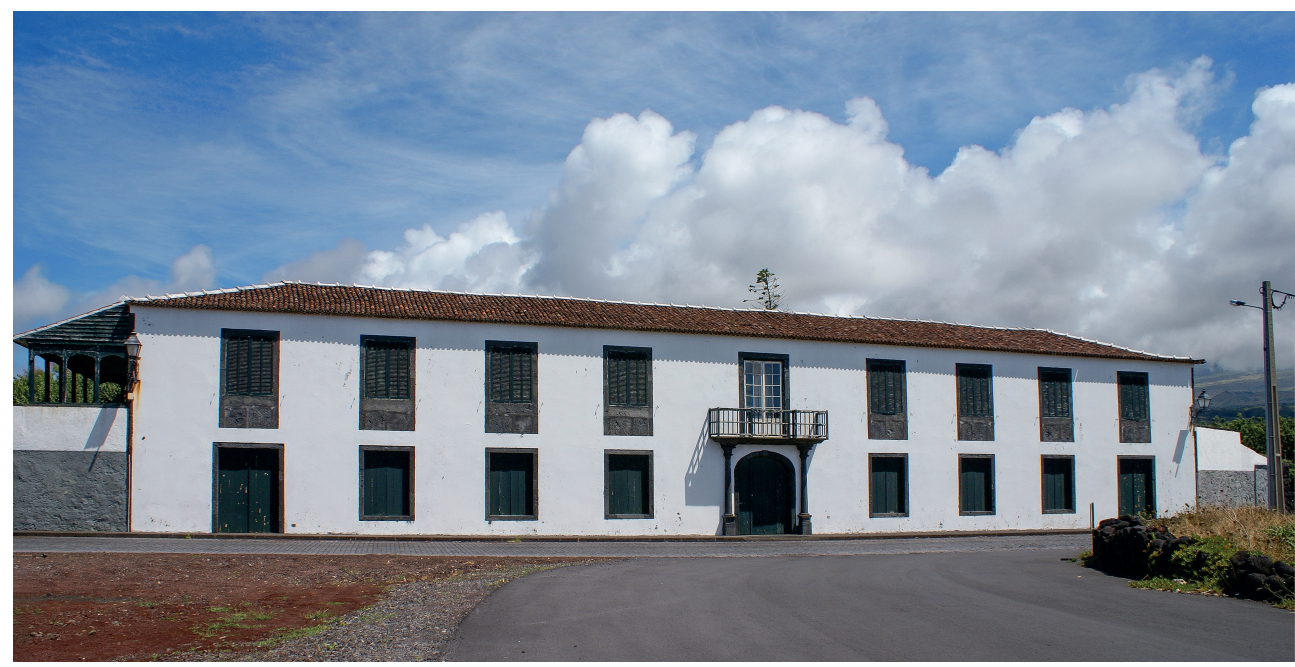

Fig. 17. Solar dos Salemas, com construção inicial dos séculos XVIII-XIX (freguesia da Criação Velha, concelho da Madalena). Fonte: Foto de José Luís Ávila Silveira/Pedro Noronha e Costa, $2010^{54}$

\section{CONCLUSÃO}

Alto Douro e Pico apresentam diferenças e semelhanças nos seus processos históricos e produtivos, quer numa perspectiva conjuntural, quer numa perspectiva estrutural.

As duas regiões apresentam particularidades que as distinguem de forma inequívoca: a área destinada à vinha, o tipo de solos e de armação do terreno, o clima, as castas e o tipo de vinho produzido.

Ressaltam, contudo, as semelhanças no processo de construção histórico-social, como, por exemplo, a complementaridade entre Porto-Douro, Faial-Pico, levando, entre outros aspectos, a que o vinho produzido nas duas regiões se tenha tornado conhecido pelo porto por onde era exportado.

A grande semelhança consiste no facto de, em ambas as regiões, se ter assistido à reivindicação da criação da marca regional. No Alto Douro, de modo mais

\footnotetext{
${ }^{53}$ SILVA, CARQUEIJEIRO, coord., 2004: 77.

${ }^{54}$ Disponível em <https://pt.wikipedia.org/wiki/Ficheiro:Solar_dos_Salemas,_concelho_da_Madalena_do_Pico,_ ilha_do_Pico,_arquipélago_dos_Açores,_Portugal.JPG>.
} 
precoce - desde finais do século XIX e com primeiros resultados na legislação de 1907-1908; na ilha do Pico, somente a partir de meados do século XX, com a criação da Cooperativa Vitivinícola, na sequência de um lento processo de reorganização pós-filoxérico e que teria o seu epílogo com o Decreto Regional $n .^{\circ}$ 25/80/ ${ }^{55}$, de 16 de Setembro, instituindo a Região Demarcada do Verdelho do Pico, e o Decreto-Lei $n .^{\circ} 17 / 94^{56}$, de 25 de Janeiro, instituindo a Denominação de Origem Protegida «Pico» e classificando o vinho nela produzido e comercializado como Vinho Licoroso Produzido em Região Determinada (freguesias da Madalena, Candelária, Criação Velha e Bandeiras, do concelho da Madalena, freguesia de Santa Luzia e parte da freguesia da Prainha, lugar da Baía de Canas, do concelho de São Roque do Pico, freguesia da Piedade, nos lugares de Engrade e Manhenha, no concelho das Lajes do Pico).

\section{FONTES}

SYMINGTON FAMILY ARCHIVES. Copiadores de correspondência da firma Silva e Cosens (anos de 1888-1891; 1897-1900; 1906-1909; 1908-1919; 1914-1922).

\section{BIBLIOGRAFIA}

AÇORES. Assembleia Regional (1980). Decreto Regional n. ${ }^{\circ}$ 25/80/A. «Diário da República Série I». 214 (1980-09-16) 2744.

AÇORES. Assembleia Legislativa Regional (1996). Decreto Legislativo Regional n. ${ }^{\circ}$ 12/96/A. «Diário da República Série I-A». 147 (1996-06-27) 1648-1650.

COSTA, Ricardo Manuel Madruga da (2004). Uma perspectiva da vitivinicultura na ilha do Pico nas duas primeiras décadas do século XIX. In O Faial e a periferia açoriana nos séculos XV a XX. Horta: Núcleo Cultural da Horta.

COSTA, Ricardo Manuel Madruga da (2005). Os Açores em finais do regime de Capitania-geral. 1800-1820. Horta: Núcleo Cultural da Horta; Câmara Municipal da Horta, vol. II.

COSTA, Susana Maria Goulart da (1995). O Pico (séculos XV-XVIIII). Contributo para o estudo de uma ilha "com pouca história". Ponta Delgada: Universidade dos Açores. Trabalho de síntese para Provas de Aptidão Pedagógica e Capacidade Científica.

DUARTE JÚNIOR, Tomaz (2004). O vinho do Pico. Madalena: Câmara Municipal da Madalena.

FAUVRELLE, Natália (1999). Quintas do Douro: as arquitecturas do vinho do Porto. Porto: FLUP. Dissertação de mestrado.

FAUVRELLE, Natália (2006). O Douro das quintas do Cima Corgo. In SOEIRO, Teresa, coord. Viver e saber fazer. Tecnologias tradicionais na região do Douro. Estudos preliminares. Peso da Régua: Fundação Museu do Douro, pp. 181-239.

GIRÃO, António Lobo de Barbosa Ferreira Teixeira (1822). Tratado teórico e prático da agricultura das vinhas, da extracção do mosto, bondade, e conservação dos vinhos, e da destilação das aguardentes. Lisboa: Imprensa Nacional.

GRÉMIO DOS EXPORTADORES DE VINHO DO PORTO (1948). Álbum comemorativo da sua instalação definitiva no Palácio da Associação Comercial do Porto. [S.l.]: GEVP.

\footnotetext{
${ }^{55}$ AÇORES. Assembleia Regional, 1980.

${ }^{56}$ PORTUGAL. Ministério da Agricultura, 1994.
} 
INSTITUIÇÃO da Companhia Geral da Agricultura das Vinhas do Alto Douro. Lisboa: Na oficina de Miguel Rodrigues, 1756.

LAGE, Otília (2018). Um caso de fronteira no «Douro novo». Carrazeda de Ansiães. Para a história do vinho do Porto. Porto: CITCEM.

MAYSON, Richard [1998]. The story of Dow's Port 1798-1998. [S. 1.]: Segrave Foulkes Publishers.

MAYSON, Richard (1999). Port and the Douro. London: Faber and Faber.

MONTEIRO, Manuel (1911). O Douro: principaes quintas, navegação, culturas, paisagens e costumes. Porto: Edições Livro Branco. Facsimile ed., 1998.

NO PAÍS do vinho do Porto (1947). Porto: Instituto do Vinho do Porto.

PEREIRA, Gaspar Martins (1991). O Douro e o vinho do Porto. De Pombal a João Franco. Porto: Edições Afrontamento.

PEREIRA, Mário Bernardes (1947). No país do vinho do Porto. Porto: Instituto do Vinho do Porto. Tradução da Parte II da obra de Henry Vizetelly Facts about Port and Madeira (London, 1880).

PORTUGAL. Ministério da Agricultura (1994). Decreto-Lei n. ${ }^{\circ}$ 17/94. «Diário da República Série I-A». 20 (1994-01-25) 354-356.

SEQUEIRA, Carla (2011). O Alto Douro entre o livre-cambismo e o proteccionismo. Porto: CITCEM; Edições Afrontamento.

SILVA, Hélder Marques; CARQUEIJEIRO, Eduardo, coord. (2004). Paisagem da Cultura da Vinha da Ilha do Pico. Candidatura a Património Mundial. Horta: Secretaria Regional do Ambiente. [Consult. 12 Jun. 2019]. Disponível em <http://whc.unesco.org/uploads/nominations/1117rev.pdf >.

SILVA, Manuel Ribeiro da (1951). A ilha do Pico sob o ponto de vista vitivinícola. «Boletim da Comissão Reguladora dos Cereais do arquipélago dos Açores». 14, 45-58.

SOUSA, Paulo Silveira e (2004). Para uma história da vinha e do vinho nos Açores (1750-1950). «Boletim do Instituto Histórico da Ilha Terceira». LXII, 57-159. [Consult. 23 Mai. 2019]. Disponível em <https:// docplayer.com.br/13593047-Para-uma-historia-da-vinha-e-do-vinho-nos-acores-1750-1950.html>. 



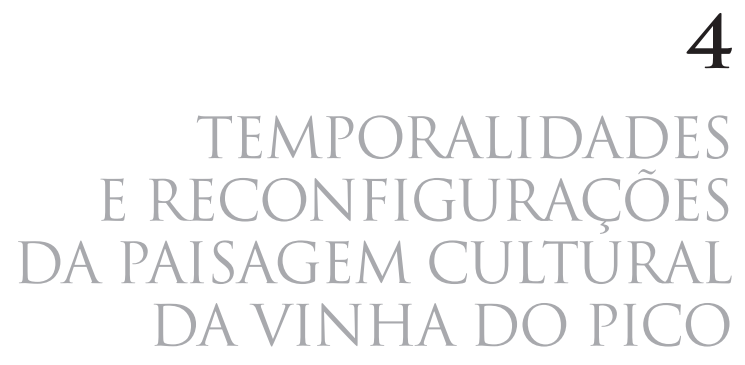





\title{
A PAISAGEM, A ILHA DO PICO E TUDO O MAIS
}

\author{
ÁlVARO DOMINGUES*
}

Resumo: A paisagem não é um dado da natureza, mas uma construção social, histórica e culturalmente situada, em permanente transformação, negociada. Mais ou menos instável e exposta a contradições, esta relação é tecida com os lugares, percepções, memórias e experiências. Contudo, a paisagem é colectiva, inscrita num contexto cultural e político, guiada por valores, códigos estéticos, representações sociais, grupos. A paisagem, por definição, caracteriza-se pela partilha da contemplação e da acção, mesmo que as formas de privatização ou as tentativas de exclusão sejam frequentes.

A paisagem somos todos nós.

Palavras-chave: Paisagem; Património; Construção social; Ilha do Pico.

Abstract: The landscape is not a datum of nature but a social, historical, and culturally situated construction, in permanent transformation, negotiated. More or less unstable and exposed to contradictions, this is a relationship woven with places, perceptions, memories, and experiences However, the landscape is collective, inscribed in a cultural and political context, guided by values, aesthetic codes, social representations, groups. The landscape, by definition, is characterized by the sharing of contemplation and action, even if forms of privatization or attempts at exclusion are frequent. The landscape is all of us.

Keywords: Landscape; Heritage; Social construction; Pico island.

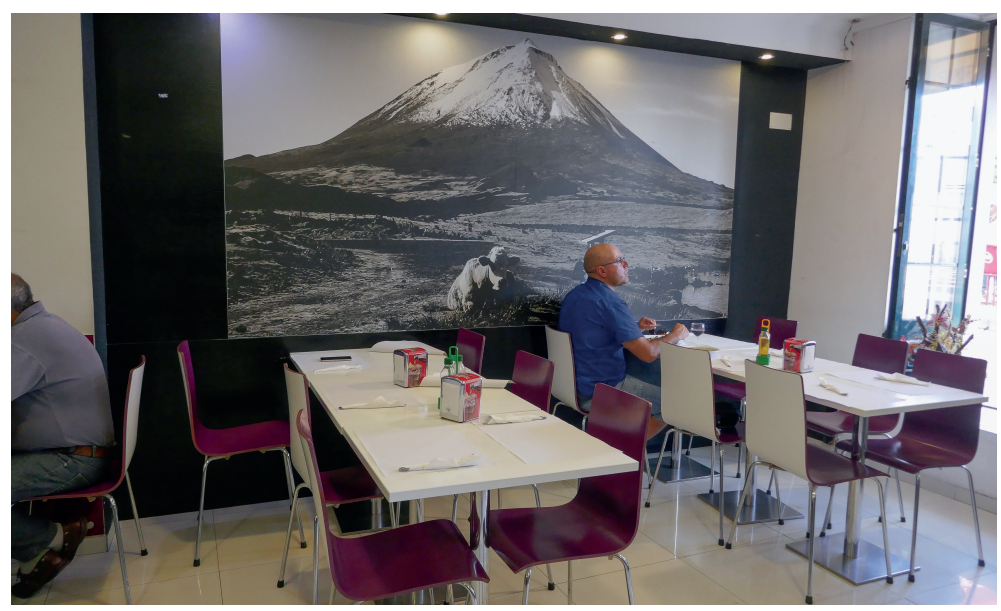

Fig. 1.

Bar-restaurante da vila da Madalena, ilha do Pico Fonte: Álvaro Domingues, 2019

* O autor não segue o Acordo Ortográfico de 1990.

Álvaro António Gomes Domingues, Professor Associado da Faculdade de Arquitectura — Universidade do Porto e Investigador no CEAU/FAUP dos Grupos de Investigação: Morfologia e Dinâmicas do Território; Património da Arquitectura da Cidade e do Território. Email: alvarodomingues2@gmail.com. 
Deambulando pelas ruas da vila da Madalena, entra-se num bar-restaurante moderno e arejado, e o olhar fica preso na parede lateral onde, num fundo escuro, sobressai uma grande fotografia do Pico. O único cliente - que nem deu pela presença do fotógrafo - está de olhos pregados na TV, terminando a sua refeição. No primeiro plano da grande fotografia, uma vaca pachorrenta, deitada, vai ruminando o espectador; atrás, a montanha formidável coberta de neve até meio da encosta "cobre-se todo este pico no inverno de pedra que chove, com que fica mais alto e todo alvo até muita parte do verão, em que o tempo quente a derrete» ${ }^{1}$. Eis a paisagem. Gaspar Frutuoso continua com a sua descrição minuciosa:

No pico pequeno, que o pico grande tem sobre si em seu mais alto cume, está um lajedo muito grande, como uma casa, a qual é furada pelo meio, em cuja concavidade recolhe quantidade de água que encherá uma pipa, de que bebe a gente que no estio sobe acima, porque enquanto dura, e se derrete a neve, que nela está recolhida no inverno, sempre correm regos de água por ele abaixo; e na faldra deste pico está outra alagoa grande, pera a banda do leste, tão comprida como um tiro de espingarda, e da mesma largura, que se chama a alagoa de Rodrigalvres, e a redor dela estão muitas casas de pastores que guardam gado vacaril e de toda a sorte [...].

É toda a terra desta ilha mui áspera e muita parte dela coberta de biscouto, sem ribeira nenhuma que corra, somente três fontes mui pequenas, duas da parte do norte e uma da banda do sul, pela qual causa a gente não bebe senão água da chuva e das árvores, que, quando chove, apanham em cabaças, e também de outra salobra, que das covas, que na areia fazem ao longo do mar, tiram².

Assim escrevia Gaspar Frutuoso vai para quinhentos anos. Diferentemente da imagem fotográfica, a descrição paisagística vai compondo um entramado descritivo a partir de factos e de relações entre factos; sucedem-se ocorrências, medições, considerações, utilidades. Ao longo dessa narrativa sucedem-se os mais variados relatos sobre as coisas julgadas importantes e portadoras de sentido, mesmo aquelas de que não houve notícia antes da ilha ser descoberta e explorada - «no cimo deste pico está uma boca aberta, de grande concavidade, em que se não acha, nem sabe fundo, por onde arrebentou em tempo antigo, de que não há notícia, antes de a ilha ser achada» ${ }^{3}$.

Ao contrário do fixismo da representação visual do território, o tempo, o decorrer das estações do ano, joga um papel importante na fisionomia mutante da paisagem. Saberemos então que do degelo da neve que se foi acumulando nos altos do pico, se

\footnotetext{
${ }^{1}$ FRUTUOSO, 1998: VI, 132.

${ }^{2}$ FRUTUOSO, 1998: VI, 132-133.

${ }^{3}$ FRUTUOSO, 1998: VI, 131.
} 
formam córregos que rapidamente se somem na terra, ou, ocasionalmente formam pequenas lagoas onde o gado vacaril vai beber.

A abundância dos pastos é um tema recorrente na descrição de Gaspar Frutuoso, apesar das repetidas vezes que fala da aspereza da terra, dos caminhos fragosos e tortos, das chapadas de lava imprestáveis e incultas, sem ribeira que corra excepto nas grandes chuvadas, sem nascentes - «somente três fontes mui pequenas» -, o que obriga as gentes a recolherem água das folhas das árvores ou mesmo de incisões em volta dos troncos:

fazem riscos nos troncos das árvores, cortando-as à roda, como anéis inclinados de uma banda, onde lhe põem por bica uma folha de árvore e, pondo nela umas jarras, cabaças, ou tinas, se estão enchendo, enquanto chove de dia e de noite, e principalmente fazem isto nos louros, porque acham ser melhor e mais sadia água que outra nenhuma; e há muitos homens que edificam suas moradas, em que vivem, em parte onde há louros, antre os matos, por rezão de ali se poderem aperceber de água pera beberem ${ }^{4}$.

Toda a ilha parece uma imensa esponja sem qualquer capacidade de armazenar água no subsolo ou nas lagoas, por muito que ela caia durante o Inverno e em muitos outros dias do ano - «sem ribeira nenhuma que corra, somente três fontes mui pequenas, duas da parte do norte e uma da banda do sul, pela qual causa a gente não bebe senão água da chuva e das árvores, que, quando chove, apanham em cabaças, e também de outra salobra, que das covas, que na areia fazem ao longo do mar, tiram» ${ }^{5}$.

Longe da estética da representação e da contemplação em imagens, esta paisagem falada descreve a construção do território com todas as suas agruras - «Come esta gente muito pouco pão por o não dar a terra» - , escarpas fragosas e algumas amenidades, a sementeira dos lugares ao longo das terras baixas da beira-mar, as vilas, os povoados..., convocando diferentes personagens e temáticas: ora são as nuvens em volta do cume que vão mudando, pressagiando sinais de chegada de tempos mareiros ou céus limpos que os habitantes das outras ilhas também podem observar; ora é a descrição de uma enseada ou de um abrigo onde se podem carregar batéis ou naus pequenas; ora são listas de personagens e famílias e seus rendimentos e dízimos devidos a feitores e proprietários de outras ilhas; ora são os matos e as madeiras, o cedro, o teixo das terras altas — «onde se acham paus muito direitos, que parecem paus de pinho e quase servem pera mastros de caraveIas pequenas» — o pau branco, a urze, o louro, a faia...; ora a descrição terrível de um fogo que arrebentou e formou

\footnotetext{
${ }^{4}$ FRUTUOSO, 1998: VI, 132.

${ }^{5}$ FRUTUOSO, 1998: VI, 133.
} 
uma ribeira de polme ardente, enxofre, salitre; ora as pescarias e, claro, as vinhas: «Em toda a terra há muitas vinhas, que dão bom vinho, e melhor que em todas as ilhas» e proporcionam bons rendimentos a quem as tem e a quem consegue vender o vinho para as outras ilhas.

A partir da escrita atenta e detalhada de Gaspar Frutuoso, a paisagem apresenta-se não como um objecto reconhecível - a palavra nem sequer é referida mas como uma categoria que o leitor dos dias de hoje facilmente lhe associa e vai preenchendo, ora recorrendo a associações entre elementos e processos naturais - as escorrências das lavas, o recorte do litoral, a topografia, a chuva, os cobertos vegetais, a cor das pedras, etc. - , ora a episódios de registo da relação entre a organização social e a transformação do território condicionada pelas condições naturais. Daqui se pode claramente entender que a importância da paisagem se compreende melhor e é mais útil quando se percebem as razões e os modos de construção dos discursos e das imagens que sobre ela se produzem, do que buscando uma definição de paisagem sempre vaga e genérica.

Continua Gaspar Frutuoso: em todo o relato sobre esta ilha mui áspera, há alusões recorrentes do trabalho insano que a sobrevivência exige, das profundas desigualdades entre os senhores da terra, do gado e dos que trabalham e pagam dízimos - «Come esta gente muito pouco pão por o não dar a terra». Na vila das Lajes, onde vive gente nobre e rica, «há muitas vinhas, que vão em muito crescimento, e grandes criações de gado vacum e ovelhum, e algumas cabras, e terras, não muitas, de lavoura de trigo e outros legumes, e muita madeira, que ali se tira do mato». Apesar dessa fartura, logo a seguir se diz que "quase toda é terra fragosa de biscoito, pedraria viva, e não tem mais terra que a que se faz das folhas das árvores, a qual se gasta o primeiro ano que se cultiva, e daí fica em pedra viva se não cria mato que torne a criar terra, como faz com as folhas do mesmo mato, etc.». Na Criação Velha, «rasa com o mar», não se fala de cultivo de vinhas mas apenas de algumas lavouras e trabalho de «fragueiros que cortam muita madeira de toda a sorte, que vendem pera as outras ilhas» ${ }^{6}$.

É estranho, mas Gaspar Frutuoso nada nos diz acerca do modo de cultivo da vinha e do fabrico dos vinhos, embora refira várias vezes as quantidades... na vila de S. Roque «onde se carregam mais de setecentas pipas; em Santa Bárbara das Ribeiras que darão cada ano mil e duzentas pipas de bom vinho»; nas Lajes onde "as vinhas vão em muito bom crescimento». Tratando-se de uma técnica tão peculiar e tão ou mais esforçada do que outras com que descreve os expedientes para produzir solo artificial ou captar água das árvores ou dos poços de marés, a descrição dos muros e dos currais não aparece. Poderão ter existido outras técnicas distintas. Poderia o cronista estar mais preocupado com o cultivo dos cereais que era tão escasso. Con-

${ }^{6}$ FRUTUOSO, 1998: VI, 128. 


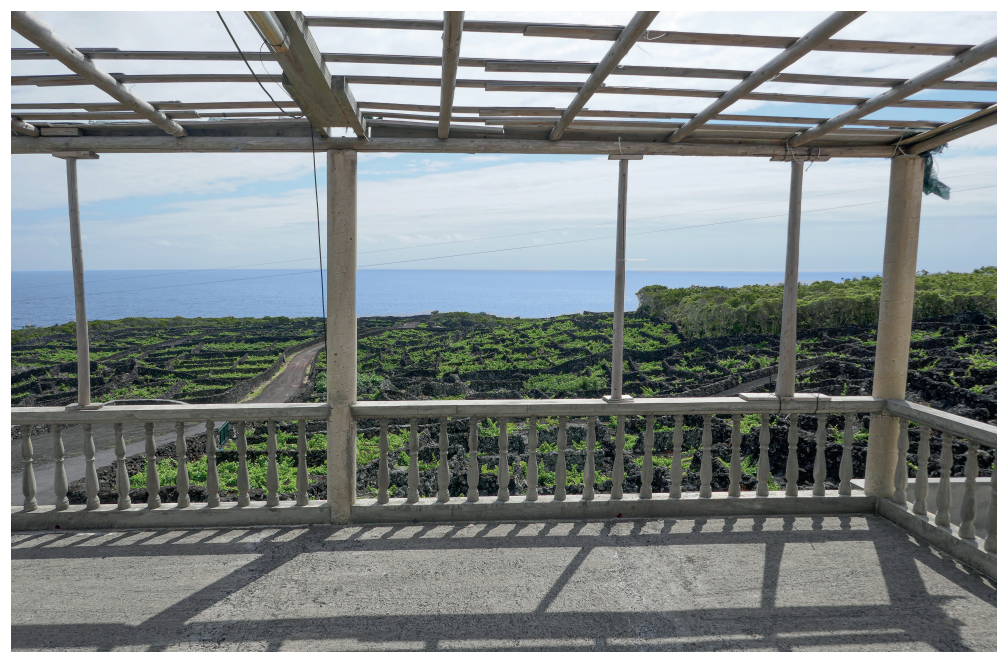

Fig. 2.

Miradouro na

Candelária, ilha do Pico

Fonte: Álvaro

Domingues, 2019

tudo, também é verdade que a migração das áreas de vinha para os brejos dos lajidos mais ocidentais da ilha onde hoje se encontra - as extensões de lava onde qualquer cultivo pareceria impossível -, é mais recente ${ }^{7}$.

Outras coisas o impressionaram, como vimos; a montanha é avassaladora... «É tão grande altura deste pico, que dizem que de riba dele se vêem todas estas ilhas dos Açores...»

Emergindo da vastidão do mar-oceano, ainda maior é a presença mineral do Pico e nessa grandiosidade se focou o cronista. Outra pessoa, outro olhar, noutro tempo, podia compor a paisagem escrita ou falada de muitos e distintos modos. O discurso sobre a paisagem, tal como a sua representação visual, é altamente selectivo, dá a ver um panorama entre muitos possíveis, uma perspectiva oblíqua da realidade, filtrada por valores, temáticas e modos de ver que conferem à paisagem a sua extrema polissemia.

Como objecto de análise, a paisagem revela-se, por isso, como um objecto de fronteira: de contornos incertos, onde se cruzam e confrontam diferentes áreas disciplinares, diferentes saberes, múltiplas racionalidades, interesses diversos e muitas modalidades de produção de sentido.

Usada como dispositivo de mediação e de argumentação para apresentar e debater questões territoriais e sociais, a paisagem, pode revelar-se um instrumento poderoso, evoluindo por etapas sucessivas, designando actores e acções, modos de ver e interpretar, valorações, regulamentos, representações visuais e narrativas, modos de dar a ver e de implicar sujeitos sociais, grupos, instituições, indivíduos. Desse jogo onde se 
multiplica o cruzamento de informação, a validação, a discussão e a controvérsia... se irá destilando a matéria de que a paisagem é feita e que muitas vezes funciona como instância capaz de produzir uma sensibilização pública, por exemplo, em torno de questões de ordenamento do território. Por ser a paisagem um lugar onde se tornam visíveis e perceptíveis os efeitos produzidos sobre um determinado quadro de vida, a sensibilidade paisagista - individual ou social - pode funcionar como factor de mobilização envolvendo diversos actores, assuntos e polémicas. A paisagem torna-se assim um dispositivo político que permite reunir, discutir, deliberar e agir.

Para se confrontar a paisagem enquanto representação visual, com aqueles que vão produzindo a sua fisionomia, é necessária uma espécie de assembleia virtual que organiza e reconhece o debate, que toma decisões e que tem a capacidade de legitimar e regular. Podemos assim questionar:

para lá da diversidade das leituras individuais, até que ponto os actores locais se estão a mobilizar para defender um relacionamento colectivo com a paisagem, ou mesmo para executar um projecto? Como é que esses actores se constroem como colectivos por meio dessa mobilização? Trata-se, portanto, de examinar aqui a performatividade de todos os tipos de discursos sobre a paisagem: como e em que medida é que se pode afirmar que o que é comum através da paisagem permite, ao mesmo tempo, ser construído como comunidade, formular um projecto e aceitar suas restrições? Podemos identificar nessas situações o desejo de gerir o cenário liderado por um colectivo ou por uma comunidade de utentes considerados ou autodeclarados legítimos, em nome de um interesse geral ${ }^{8}$ ?

Se a resposta for afirmativa, essa pode ser uma paisagem como a Paisagem da Cultura da Vinha da Ilha do Pico, ao mesmo tempo caracterizada por determinados traços que lhe conferem uma forte identidade, por uma tessitura institucional que se revê nessa identidade, que nela participa e que, através da sua acção, mobiliza os principais construtores de paisagem: os produtores de vinhas. Para além desses, em torno da fileira do vinho e da vinha, existirão outros actores, instituições, relações de poder, processos de decisão, lógicas de gestão. Todos, com uma ligação mais ou menos directa à fileira económica do vinho, são partes envolvidas. O programa financeiro criado pelo Governo Regional dos Açores para reabilitação das vinhas localizadas nas áreas classificadas e nas zona-tampão ${ }^{9}$, exigindo o uso de métodos e técnicas de cultivo, e de castas de vinha tradicionais, constitui um desses exemplos que funciona como um poderoso mobilizador e regulador da produção de paisagem.

\footnotetext{
${ }^{8}$ SGARD et al., 2018: 105-122. Tradução do autor.

${ }^{9}$ Decreto Regulamentar Regional n. ${ }^{\circ}$ 12/2004/A, de 24 de Abril de 2004 (AÇORES. Presidência do Governo, 2004), alterado pelo Decreto Regulamentar Regional $n .^{\circ}$ 8/2006/A, de 9 de Fevereiro (AÇORES. Presidência do Governo, 2006).
} 
A área de produção passou de cerca de 120 hectares em 2004, para cerca de 980 hectares no ano de 2019.

Além do programa de reabilitação das vinhas, podem-se elencar outros acontecimentos/iniciativas importantes na teia institucional produtora e legitimadora da identidade paisagística das vinhas do Pico:

- em 1961 a criação da Cooperativa Vitivinícola da Ilha do Pico;

- em 1996 a classificação do Governo Regional dos Açores da Paisagem Protegida de Interesse Regional da Cultura da Vinha da Ilha do Pico, com uma área inicial de cerca de 3000 hectares;

- em 1999, após a reconstituição e recriação da casa dos frades carmelitas na vila da Madalena, inaugura-se o Museu do Vinho;

- em 2001, a candidatura a Património Mundial da Paisagem da Cultura da Vinha da Ilha do Pico pela Secretaria Regional do Ambiente;

- em 2004, a Paisagem da Cultura da Vinha da Ilha do Pico foi reconhecida pela UNESCO como Património da Humanidade;

- a partir de 2004, os programas de financiamento aprovados pelo Governo Regional destinados à manutenção/recuperação vinha;

- em 2006, a aprovação do Plano de Ordenamento da Paisagem Protegida da Cultura da Vinha da Ilha do Pico;

- em 2010 é inaugurado o Centro de Interpretação da Paisagem da Cultura da Vinha da Ilha do Pico, no Lajido de Santa Luzia;

- em 2018, é atribuído o Prémio Nacional da Paisagem pelo Ministério do Ambiente.

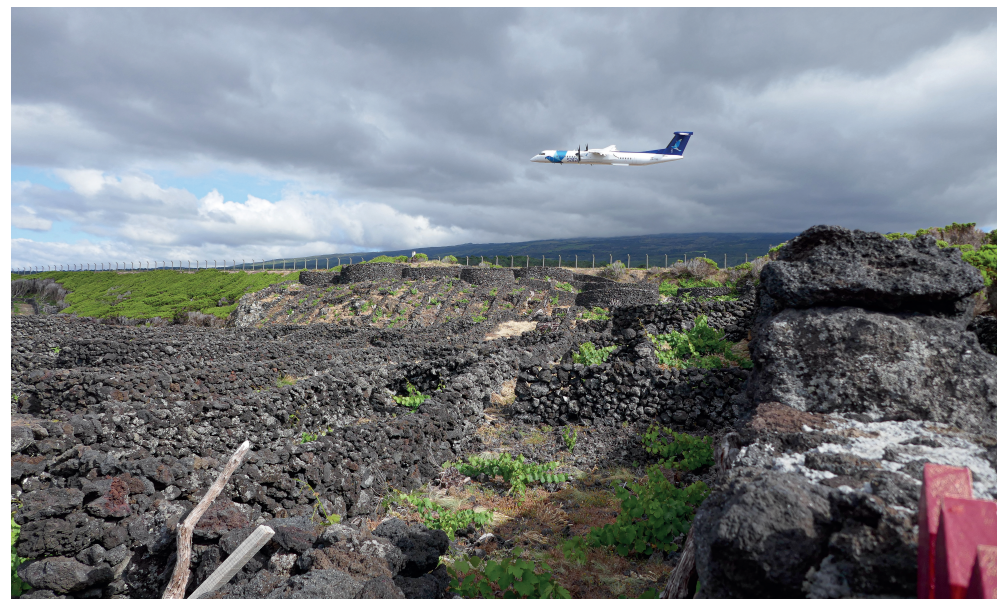

Fig. 3.

Vinhas nas proximidades do aeroporto da ilha do Pico Fonte: Álvaro

Domingues, 2019 
Esta sequência de acontecimentos constitui uma grelha de produção de imagens, modelos, formas de regulação, acções, etc., que têm contribuído para uma grande homogeneidade de procedimentos e resultados caracterizadores da Paisagem da Cultura da Vinha da Ilha do Pico.

A narrativa e a iconografia da paisagem são bastante simples:

uma faixa de território que abrange parcialmente as costas Norte e Sul, e a costa Oeste da ilha, tendo como referência emblemática dois sítios - o Lajido da Criação Velha e o Lajido de Santa Luzia, implantados em extensos campos de lava caracterizados por uma extrema riqueza e beleza natural e paisagística. Estes sítios foram classificados por constituírem excelentes representações da arquitetura tradicional ligada à cultura da vinha, do desenho da paisagem e dos elementos naturais. A diversidade faunística e florística aí presente, está associada a uma abundância de espécies e comunidades endémicas, raras e com estatuto de proteção.

Este bem consiste numa espantosa rede de longos muros de pedra, espaçados entre si, que correm paralelos à costa e penetram em direção ao interior da ilha. Estes muros foram erguidos para proteger do vento e da água do mar as videiras, que são plantadas em milhares de pequenos recintos retangulares (currais), colados uns aos outros. Remontando ao século XV, a presença da viticultura manifestou-se através desta extraordinária manta de retalhos de pequenos campos, de casas e quintas do início do século XIX, de ermida, portinhos e poços de maré. A paisagem modelada pelo homem, de uma beleza extraordinária, é o melhor testemunho que subsiste de uma atividade outrora muito ativa ${ }^{10}$.

A construção de uma retórica e de um imaginário paisagificado de um território revela-se uma fonte muito interessante sobre os valores subentendidos nesses regimes de visibilidade da paisagem, aquilo que é destacado, as narrativas usadas para destacar um ou outro traço, uma identidade, ou até aquilo que se tolera ou não em termos de modos de acção sobre a preservação/transformação dessa paisagem/território. A circulação de imagens sobre a paisagem, os temas privilegiados, os pontos de vista, a luz, os elementos em destaque..., contêm, implícita ou explicitamente, informações preciosas sobre aquilo que realmente preenche o sentido do comum, do que é reconhecido e partilhado: como enunciado colectivo, domínio de interesse geral e mesmo formas de acção. Quando, a propósito de uma determinada paisagem, se denuncia esta ou aquela prática como exemplo do que está certo ou errado fazer-se, estamos perante modos de comunicação e de validação de códigos do "sentir colectivo» sobre aquilo que é considerado património, recurso comum traduzido nessas repre-

\footnotetext{
${ }^{10}$ Paisagem da Vinha da Ilha do Pico, [s.d.].
} 
sentações, julgamentos ou actos. Quanta mais informação circular na esfera pública (o grau de intensidade de publicitação) e mais frequentes forem os confrontos (acordos ou controvérsias) entre actores sociais, melhor se conhecerão os campos sociais mais intensamente envolvidos na paisagem como matéria em discussão. Entre elites muito restritas, grupos locais fortemente vinculados a esses territórios, ou maiorias alargadas, por vezes, genéricas e massificadas, mais claramente perceberemos a geometria social em presença e aquilo de que se fala quando se fala de paisagem. Perante sentimentos de perda ou afirmações de identidade - um incêndio, o abandono de práticas e modos de fazer que quebram longas estabilidades, a intrusão de materiais e formas nunca vistos até então...-, o território que a paisagem representa ( a face desse território) e veicula, revelar-se-á com um máximo de nitidez; os colectivos sociais em presença, também.

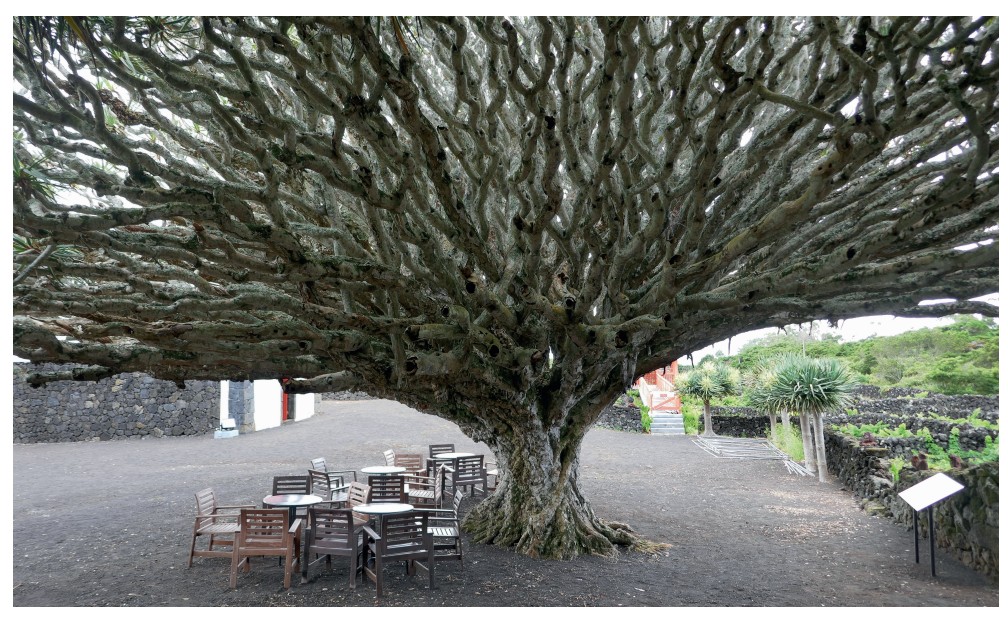

Fig. 4.

Dragoeira secular. Museu do Vinho (vila da Madalena), ilha do Pico Fonte: Álvaro Domingues, 2019

Há na ilha do Pico muita mais paisagem do que apenas a das vinhas, apesar desta ser considerada de maior valor patrimonial, identitário e também mercantil; a paisagem dos currais negros da vinha é emblemática, e a dureza que transmite, reforça o trabalho e o artifício que ali se cumpre continuamente. A paisagem da vinha é uma paisagem extraordinária. Existem depois as paisagens mais ou menos comuns, as que não foram destacadas, não possuem nome próprio ou regimes especiais de existência.

Atendendo apenas às classificações de zonamento contidas no Parque Natural da Ilha do Pico, podem-se enumerar: Reservas Naturais, Monumentos Naturais, Áreas Protegidas para Gestão de Habitats ou Espécies, Áreas de Paisagem Protegida, Áreas Protegidas de Gestão de Recursos, Reservas Florestais, Zonas de Protecção Especial; a esta lista somam-se ainda 18 Geossítios. Não sendo a legenda de um atlas de paisagens, esta extensa lista é suficientemente eloquente enquanto indicador da grande diversidade paisagística da ilha. 


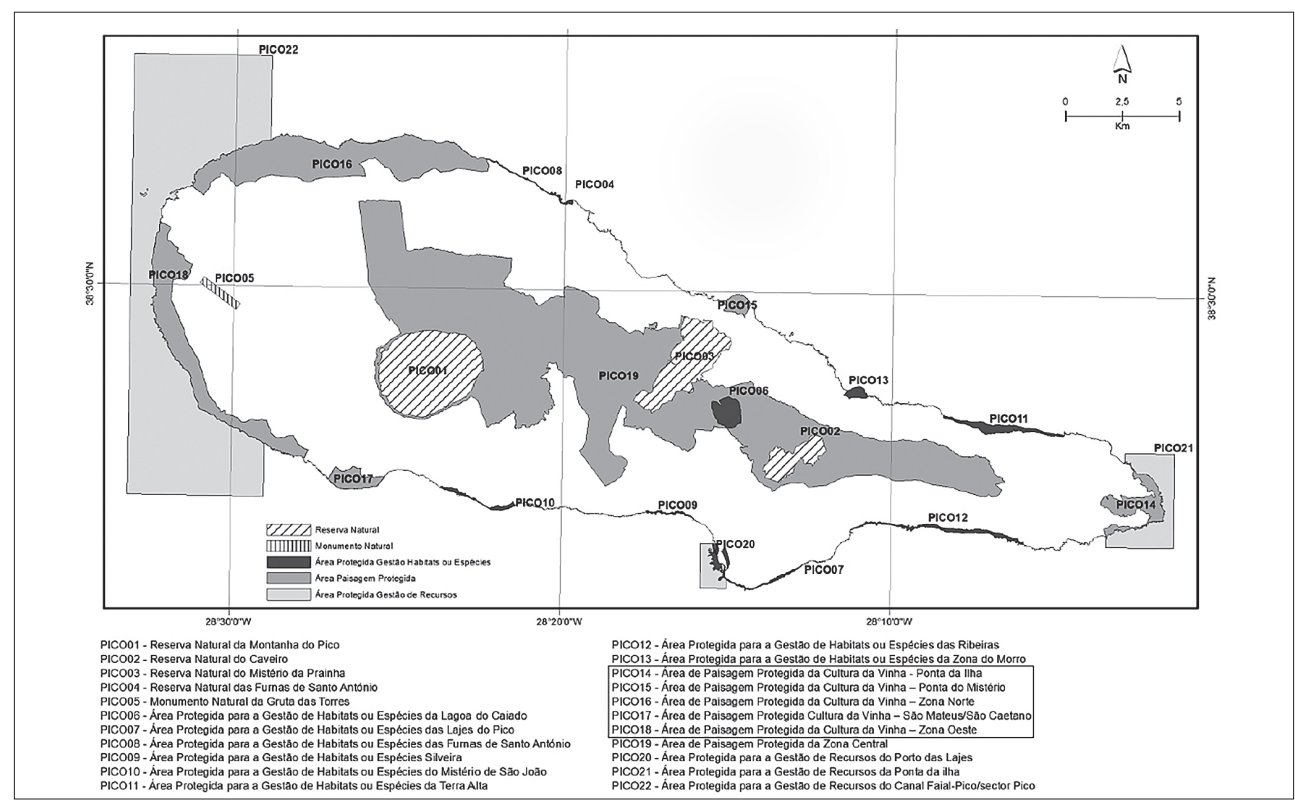

Mapa 1. Parque Natural da Ilha do Pico - áreas protegidas

Fonte: MOREIRA, 2013

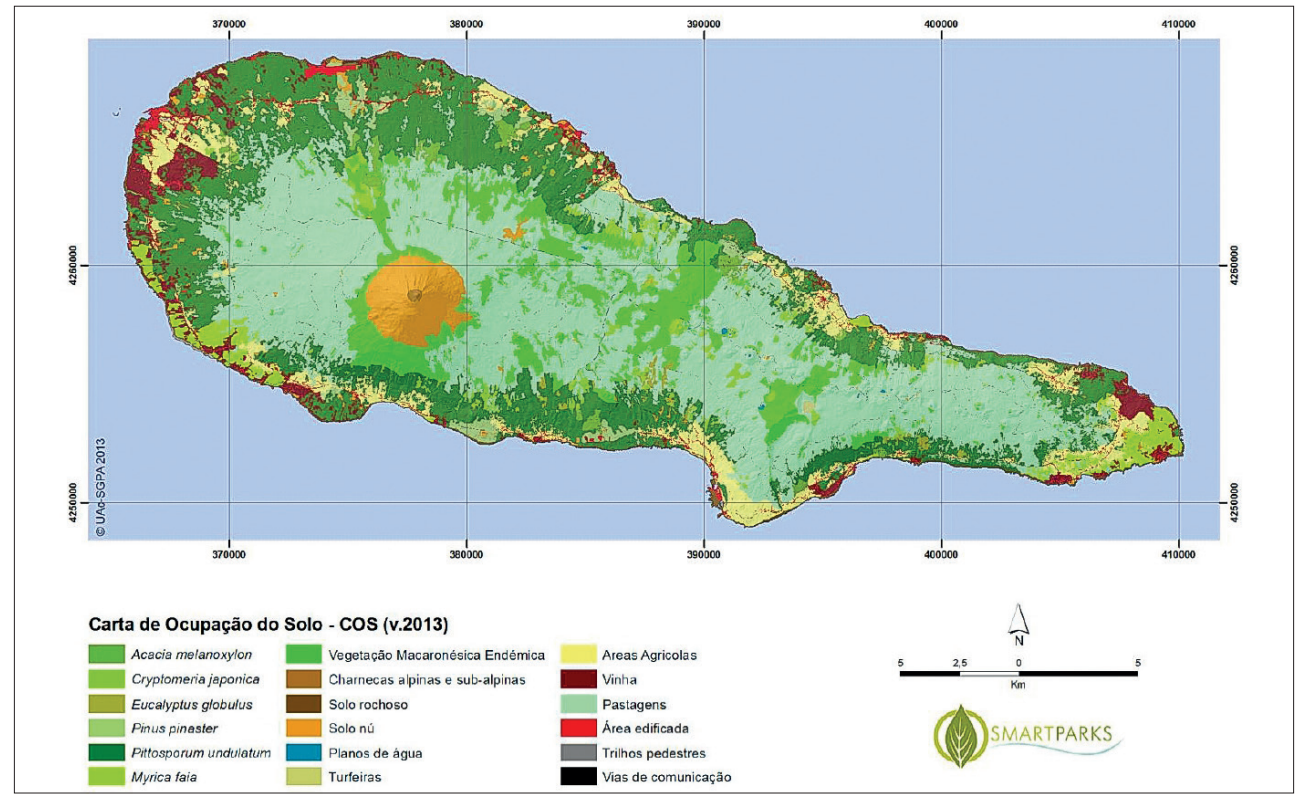

Mapa 2. Carta de ocupação do solo (metodologia InVEST Biodiversity Model)

Fonte: MOREIRA, 2013: 15 
Vale a pena ler um texto de promoção do Parque Natural da Ilha do Pico:

Ao explorar o Parque Natural do Pico, poderão desfrutar de diversas experiências inesquecíveis, desde um mergulho nas águas límpidas do oceano, a um passeio de barco para observação de baleias e golfinhos, passando por uma caminhada nos trilhos de basalto em "lajidos" e "mistérios", explorando os muitos quilómetros de grutas vulcânicas, ou subindo as encostas escarpadas em direção ao planalto central, polvilhado de vulcões, de lagoas, de vegetação natural e de pastagens, até atingirem o ponto mais alto de Portugal, a Montanha do Pico.

Mas a ilha do Pico não é só natureza, não é só paisagem, é também gente. Gente que soube aproveitar uma paisagem inóspita para da pedra fazer vinho e que se aventurou no mar à caça da Baleia, sempre em busca do seu sustento.

Por tudo isto e por muito mais que a ilha tem para oferecer, quer seja através de um mergulho no oceano, de um passeio de barco, a pé ao longo de trilhos, de bicicleta, de carro, a ver o azul do mar, o verde da vegetação, o negro da rocha, o pôr-do-sol que nunca é igual, a ouvir o som dos cagarros, a sentir a aspereza e o calor das rochas ou simplesmente a relaxar, ouvindo o mar a bater nas rochas ou a escutar o silêncio, a provar um vinho verdelho um queijo do Pico ou um caldo de peixe, decerto que a ilha do Pico não o irá deixar indiferente.

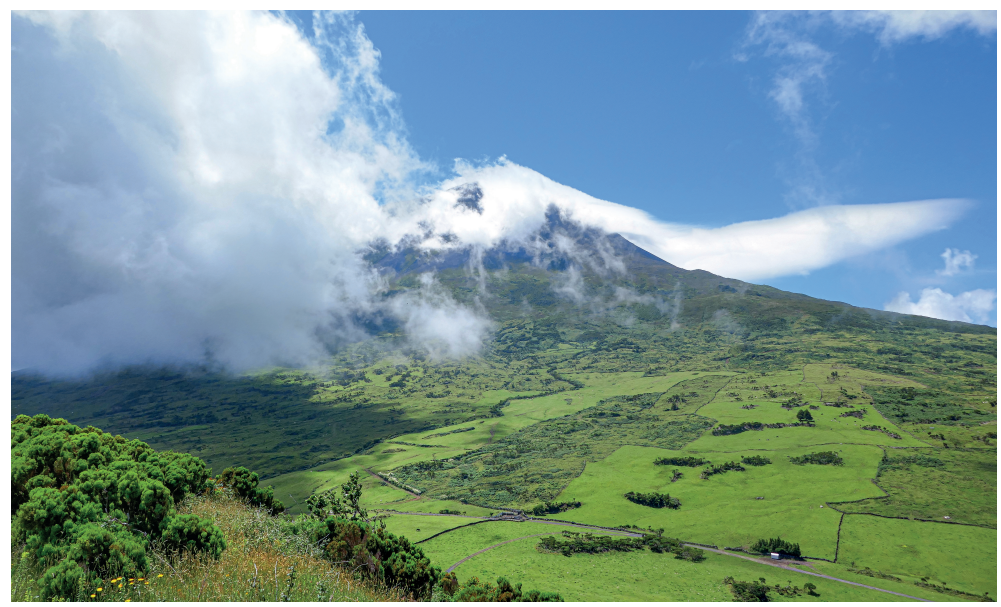

Fig. 5.

Montanha do Pico ilha do Pico Fonte: Álvaro Domingues, 2019

Não deriva desta descrição uma narrativa exclusivamente paisagística; aconselham-se experiências desportivas, sensoriais, passeios; existe claramente um estilo promocional orientado ao turista/visitante.

A paisagem é uma categoria conceptual a preencher, a inventar. 

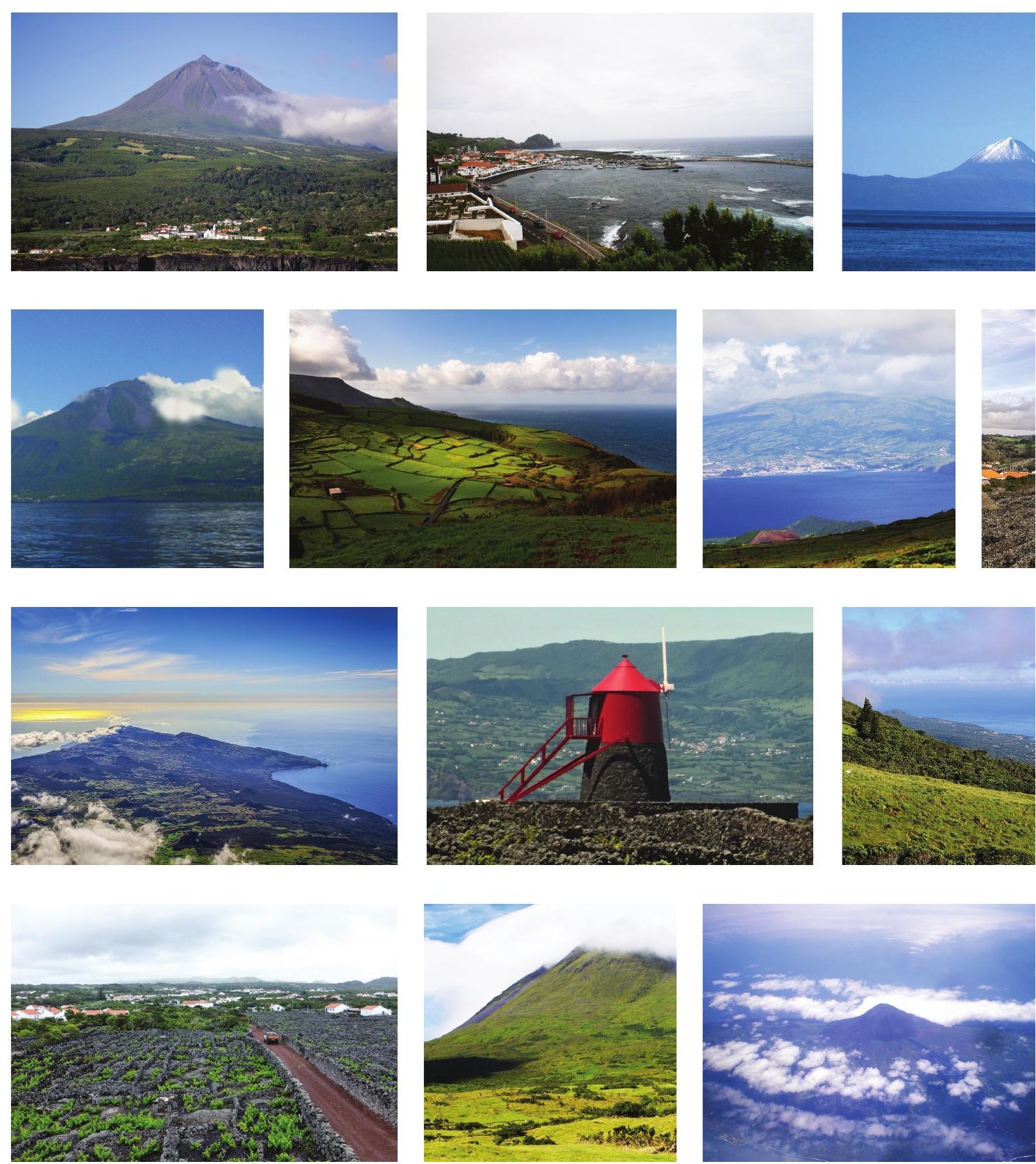

Fig. 6. Ilha do Pico - (Abril 2021)

Fonte: Wikimedia Commons, Pixabay e Unsplash (ver informação completa no final do artigo) 
Pode-se afirmar que até muito recentemente - a paisagem é uma categoria patrimonial reconhecida em 1972 pela Convenção do Património Mundial; em 1992 pela UNESCO como Paisagens Culturais; a Convenção Europeia da Paisagem data de 2000 - a paisagem estava confinada a três regimes de visibilidade dominantes:

- no campo artístico, com uma larga tradição vinda sobretudo da pintura europeia do século XVII e desenvolvendo-se até hoje através de outras estéticas, outros suportes como a fotografia, o cinema e as artes digitais. Na literatura, agora sob a designação de geopoética, as narrativas paisagísticas existem desde a consagrada literatura de viagem do século XIX até hoje.

- esta artialisação ${ }^{11}$ da paisagem produziu um gosto popular muito generalizado em reproduções de pintura ou fotografia em calendários, postais-ilustrados, publicações sobre viagens e turismo, etc. Com a digitalização e as telecomunicações, a banalização da fotografia expandiu enormemente o campo de produção e de circulação de imagens de paisagens e respectiva adjectivação;

- no campo científico, existe uma larga tradição de estudos de paisagem na Geografia e na Arquitectura Paisagista. Mais recentemente, como é exemplo o próprio Pico, a paisagem entrou como categoria no próprio ordenamento do território, normalmente através de uma via patrimonialista, privilegiando medidas de salvaguarda e protecção. As questões ambientais e os desígnios da denominada protecção da natureza, trouxeram também um renovado interesse sobre a paisagem.

Hoje, a tendência para a paisagificação não tem limites ${ }^{12}$. Provavelmente porque vivemos numa sociedade intensamente consumidora de imagens, a diversidade da representação da paisagem e das narrativas associadas, não conhece limites. Existem paisagens em tudo e para tudo.

Extraordinárias ou banais, as paisagens exprimem o modo como uma sociedade produz e, continuamente, transforma o território. É por esta razão que a paisagem enquanto dipositivo de partilha e discussão sobre territórios/sociedades se revela de uma extrema utilidade para se perceber de que se fala realmente quando se fala de paisagem, quem usa a palavra, que argumentos defende, que estratégias de legitimação suportam a autoridade de quem fala e do que fala, enfim, quais são e o que revelam as polémicas políticas sobre a paisagem, os lugares comuns dos colectivos que se envolvem nessas polémicas.

\footnotetext{
${ }^{11}$ Cf. ROGER, 1997.

${ }^{12}$ CAUQUELIN, 1989.
} 
Em sociedades relativamente simples e estáveis como aquelas que estudou Jorge Dias em Vilarinho da Furna ${ }^{13}$, os traços dominantes da cultura comunitária designariam relações muito claras no que toca às coisas e aos valores comuns, quer fosse a natureza dos bens em questão, dos valores, dos seus significados, modos de apropriação e de gestão, e respectivas espacialidades.

O património colectivo - material ou imaterial - sobrepunha-se ao individual na medida em que a colectividade (e o regime comunitário que a regulava) era a sociedade/território onde cada um inscrevia a sua individualidade, a sua margem de individuação face ao grupo e às regras do grupo.

A propósito das culturas camponesas, é um ponto consensual o facto de não existir aí um olhar paisagista no sentido comum da expressão. Quando interpelado sobre as qualidades estéticas da paisagem, o camponês responde através de um registo muito utilitário: uns belos campos são aqueles que estão bem trabalhados, cuidados, produzindo colheitas abundantes; feio é tudo que é inculto, infértil, mal trabalhado. $\mathrm{O}$ ethos dominante deriva da centralidade da produção, do trabalho, do produto que a terra dá para que se tenha sustento.

Desde logo, o grupo social, a comunidade, e o seu território estavam perfeitamente definidos e as suas cartografias reais ou imaginadas, também. Sabia-se quem pertencia ou não ao grupo - nós e os outros - e eram claros os tipos de vínculos, os direitos e os deveres. Na vida de todos os dias, nos momentos extraordinários, na festa, no casamento, nas partilhas, na morte, neste mundo e no outro, havia códigos de ética e de moral que clarificavam ao máximo o lugar de cada um no todo. A sociedade dos indivíduos estava cercada pelos imperativos do comum, da vida em comunidade e dos seus apurados mecanismos de funcionamento e de regulação.

As coisas comuns - os lameiros, os baldios, as águas, a vezeira, o boi do povo, os abrigos na serra, o forno comunitário, a igreja, as alminhas, os caminhos, os largos, etc. - inscreviam-se em espacialidades bastante claras, modos de usar, recortes claros entre os interesses privados e o interesse público, comum. Das macroespacialidades como o baldio onde se apascentavam gados e se recolhia lenha, às micro espacialidades como o largo da igreja; da definição clara de áreas e recintos como os lameiros, às redes e sistemas como os poços e nascentes, açudes, regos, poços onde se explorava, conduzia, armazenava e distribuía a água de rega ou de lima..., mas também os rituais da morte e da vida, as celebrações, a ética, a estética e a moral, os usos e costumes, constituíam um «todo» quase blindado. Nestes pequenos mundos do comunitarismo agro-pastoril, o património estava implícito. Antes do indivíduo nascer, já existia - estável e organizado - o mundo que o ia receber, a sua relativa

${ }^{13}$ DIAS, 1948. 
homogeneidade e auto-suficiência. Tudo estava claramente intuído, todos sabiam o que esperar de cada um.

Por outras palavras, as várias declinações do património comum - a designação das coisas, o seu significado prático ou simbólico, as suas funções e utilidades, a tomada de decisão, as pessoas envolvidas, a partilha das responsabilidades, dos direitos e dos deveres, e as práticas de gestão, apropriação, manutenção - , deixavam margem reduzida para que o aleatório e o vago se instalassem. Em caso de conflito havia instâncias - conselhos ou indivíduos - e práticas de mediação tidas como legítimas e eficazes nas suas decisões.

Numa tal situação, o território - e as territorialidades —, também não punham dúvidas de maior. O quadro natural (ou geográfico), tal como escrevia Jorge Dias, era um quase determinismo para a organização social, para os modos de vida, o habitat. Recorde-se que o conceito de habitat provém das ciências naturais, correspondendo em matéria de ecologia ao lugar onde se reúnem certas condições (bióticas e abióticas) apropriadas à vida (sobrevivência e reprodução) de um organismo, espécie ou comunidade animal ou vegetal (ou para associações), definindo assim o conjunto de recursos e de condicionalismos necessários para a ocupação de um determinado espaço durante um certo tempo.

Se os de Vilarinho da Furna fossem questionados sobre o que poderia ser uma representação de paisagem de Vilarinho, mesmo que a referência à palavra paisagem nunca aparecesse - como nas descrições de Gaspar Frutuoso sobre as ilhas -, com certeza que as concordâncias seriam muitas e convergiriam sobre os vários territórios da produção - dos baldios no monte, aos lameiros e aos campos próximos da aldeia. Uma sociedade de base económica agrícola e pastoril falaria da paisagem por si produzida, pelas suas actividades principais e modos de fazer.

Tudo estava devidamente demarcado, nomeado, sujeito a interpretações, normas e regras. A rudeza da vida dependente do que a terra dava, da chuva no seu tempo, do calor, das estações, das maleitas dos animais, tudo concorria para uma interdependência muito forte, um quase determinismo entre as condições do meio natural e os modos de vida. Da mesma pedra que abundava na serra se faziam as casas e as cortes dos animais, os muros, o bebedouro das galinhas, a igreja ou a pia baptismal. Os lameiros ou os pastos altos das brandas na serra, consoante fosse Inverno ou Verão, marcavam os trabalhos e os dias tal como o ciclo de vida dos cereais ou dos animais.

$\mathrm{O}$ isolamento a que estes locais estavam votados e o ambiente por vezes inóspito destas terras frias, marcavam indelevelmente a economia e as relações sociais, a organização do espaço e do imaginário. O próprio comunitarismo podia ser visto como uma estratégia de sobrevivência, um modo de afrontar condições adversas. Por sobre qualquer impulso de mudança, a tradição, os antepassados, as rotinas, eram mais importantes 
do que as rupturas, as mudanças. Sociedade e território rurais compunham uma paisagem, uma configuração visual reveladora de um equilíbrio longamente estabilizado entre as práticas culturais e os constrangimentos biofísicos.

O trabalho e a festa, as famílias e os animais, o natural e o sobrenatural partilhavam estes espaços, inscreviam-se social e territorialmente, tornando estes dois registos inseparáveis: o que define o lameiro como património comum é ao mesmo tempo descrito dentro de um âmbito territorial e de um sistema de normas e acções.

Vilarinho da Furna está debaixo de água desde que foi concluída a barragem homónima em 1972. É uma paisagem submersa, espécie de jazida arqueológica de um certo Portugal rural pré-moderno.

Não é, não foi assim na ilha do Pico. Apesar do seu carácter relativamente periférico, as mudanças sociais, a exposição a dinâmicas globais e o processo de modernização foram seguindo o seu caminho, ora produzindo mudanças lentas, ora súbitas disrupções que no território diverso da ilha foram introduzindo marcas diversas. $\mathrm{O}$ aumento rápido da paisagem da vinha ilustra um desses processos: $\mathrm{o}$ valor económico, o empenho político, os tempos que correm favoráveis à estetização da vinha e do vinho, o próprio carácter excepcional da construção da paisagem, tudo contribui para a visibilidade acrescida do fenómeno e da sua ampla partilha por actores sociais diversos.

Contudo, nas sociedades complexas e instáveis de hoje, será muito difícil encontrar consensos generalizados sobre o que seja a paisagem ou que préstimo possa ter. Perdido o consenso social existente nos grupos comunitários de outrora como é o caso de Vilarinho da Furna, a sociedade pulveriza-se em grupos, pertenças, vínculos de geometria variável, repartindo modos distintos de ver o mundo e de ver as paisagens. Haverá acordos sobre registos muito comuns que de tão intensamente vistos e

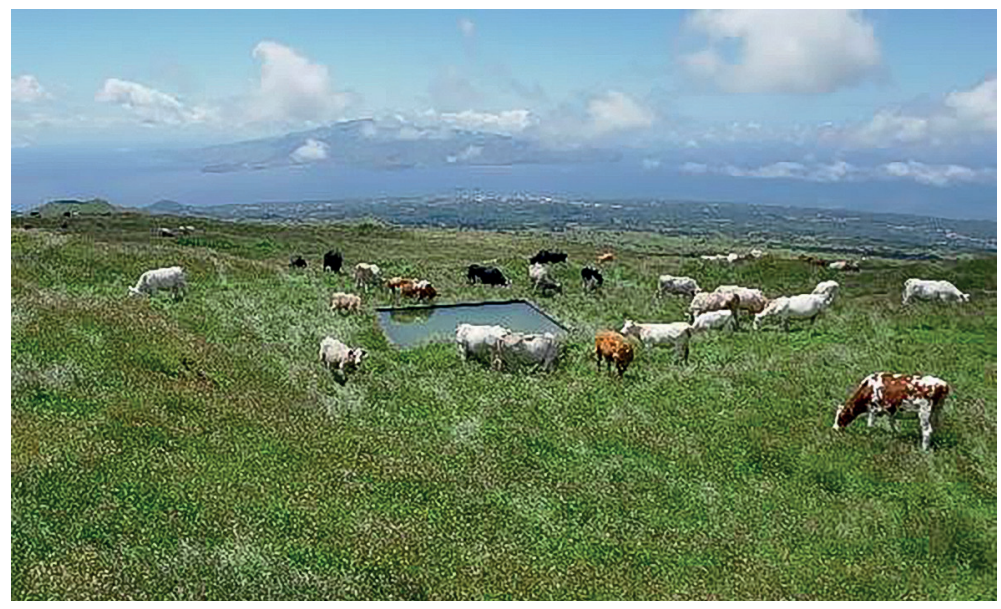

Fig. 7.

Pastagens em

Santa Luzia

Fonte: Álvaro

Domingues, 2019 
partilhados por todos, mas de uma forma bastante epidérmica, se transformarão em genéricos. As vinhas também tocam esse registo aligeirado, mesmo que, ao mesmo tempo, existam numa relação sociedade/território muito coesa e firme.

Porque construído pelos sentidos e pelas palavras comuns, a paisagem está ao alcance de todos e pode ser partilhada no quotidiano da vida prática ou no imaginário de cada um, e pode constituir um dispositivo relevante acerca do modo como organizamos vida em conjunto, territórios que são casa comum.

É vulgar pensar-se que a paisagem é considerada sobretudo como uma ferramenta de observação, de leitura mais ou menos aprofundada e, raramente, como uma ferramenta de pensamento direccionada à acção, questionando os actores e o seu vínculo com o território, ou ainda como objecto de debate ou controvérsia cuja análise permite uma incursão importante na compreensão dos territórios.

Longe da beira-mar e das vinhas, nas pastagens altas da ilha do Pico não houve ainda razões para paisagificar com a mesma intensidade com que se tem feito para o caso do vinho. Podia-se dizer quase literalmente que as vacas comem e ruminam as matérias da paisagem, animam-na, fazem parte dos colectivos humanos e não humanos produtores dessa paisagem.

Paisagem somos todos nós.

\section{BIBLIOGRAFIA}

AÇORES. Presidência do Governo (2004). Decreto Regulamentar Regional n. ${ }^{\circ}$ 12/2004/A. «Diário da República Série I-B». 97 (2004-04-24) 2556-2558.

AÇORES. Presidência do Governo (2006). Decreto Regulamentar Regional n. ${ }^{\circ}$ 8/2006/A. «Diário da República Série I-B». 29 (2006-02-09) 1052-1054.

CAUQUELIN, Anne (1989). L'invention du paysage. Paris: PUF.

DIAS, Jorge (1948). Vilarinho da Furna: Uma Aldeia Comunitária. Porto: Instituto para a Alta Cultura; Centro de Estudos de Etnologia.

FRUTUOSO, Gaspar, (1998). Saudades da Terra. Ponta Delgada: Instituto Cultural de Ponta Delgada, livro VI. MACIEL, Maria (2018). Paisagem da vinha do Pico - antes e depois da filoxera. Perspetiva económica e social. In LAGE, Otília, coord. Alto Douro e Pico, Paisagens Culturais Vinhateiras Património Mundial em perspectiva Multifocal. Porto: CITCEM, pp. 99-111.

MOREIRA, Miguel; GIL, Artur (2013). Valoração da biodiversidade no Parque Natural da Ilha do Pico através da metodologia InVEST, Thechnical report developed under the SMARTPARKS Project. Lisboa: Universidade de Lisboa; FCT. DOI: https://www.researchgate.net/publication/314197267. PAISAGEM DA VINHA DA ILHA DO PICO [s.d.]. In COMISSÃO NACIONAL DA UNESCO; PORTUGAL. Ministério dos Negócios Estrangeiros. Comissão Nacional da UNESCO. [Consult. 11 Dez. 2020]. Disponível em <https://www.unescoportugal.mne.pt/pt/temas/proteger-o-nosso-patrimonio-epromover-a-criatividade/patrimonio-mundial-em-portugal/paisagem-vinha-da-ilha-do-pico> .

PARQUE NATURAL DO PICO. In Parques Naturais dos Açores. [Consult. 11 Dez. 2020] Disponível em <http://parquesnaturais.azores.gov.pt/pt/pico/noticias/locais/1047-parque-natural-do-pico $>$. ROGER, Alain (1997). Court traité du paysage. Paris: Gallimard.

SGARD, Anne et al. (2018). Construire en commun par le paysage. Trois controverses paysagères relues à l'aune du bien commun. «Espaces et sociétés». 4:175, 105-122. 
Veja-se abaixo a informação detalhada sobre as fontes das imagens que compõe a figura 6 do presente artigo.

1. Foto de Maria e Fernando Cabral por Pixabay.

$2,3,6,8,18,20$. Fotos de José Luís Ávila Silveira/Pedro Noronha e Costa. Obra do próprio, Domínio público, por Wikimedia Commons.

4, 22. Fotos de Carlos Luís M. C. da Cruz. Obra do próprio, Domínio público, por Wikimedia Commons.

5. Foto de Navin75 por Wikimedia Commons, CC-BY-SA-2.0. Disponível em <https://commons. wikimedia.org/wiki/File:Landscape_of_the_Pico_Island_Vineyard_Culture_(50639801592).jpg>.

7. Foto de Kévin e Laurianne Langlaison por Unsplash.

9. Foto de Matheus Hobold Sovernigo por Wikimedia Commons, CC-BY-SA-4.0. Disponível em $<$ https:// commons.wikimedia.org/wiki/File:Paisagem_da_Cultura_da_Vinha_da_Ilha_do_Pico_-_Ilha_ do_Pico,_Portugal.jpg >.

10. Foto de Wo st 01 por Wikimedia Commons, CC BY-SA 3.0 DE. Disponível em <https://commons. wikimedia.org/w/index.php?curid=14784471>.

11. Foto de Walter Frehner por Pixabay.

12. Foto de Samuel Monteiro Domingues por Wikimedia Commons, CC-BY-SA-4.0. Disponível em $<$ https://commons.wikimedia.org/wiki/File:Ilha_do_Pico_-_Açores.jpg >.

13. Imagem de Vianney Dugrain por Pixabay.

14. Foto de Navin75 por Wikimedia Commons, CC-BY-SA-2.0. Disponível em <https://commons. wikimedia.org/wiki/File:Pico_Island_(50683154983).jpg>.

15. Foto de Navin75 por Wikimedia Commons, CC-BY-SA-2.0. Disponível em <https://commons. wikimedia.org/wiki/File:Pico_Island_(50686907818).jpg>.

17. Foto de Werner Paris por Wikimedia Commons, CC-BY-SA-4.0. Disponível em <https://commons. wikimedia.org/wiki/File:Pico_Island_Vineyard_5.jpg>.

19. Foto de Froth82 por Wikimedia Commons, CC-BY-SA-3.0,2.5,2.0,1.0. Disponível em <https:// commons.wikimedia.org/wiki/File:Pico_Island.JPG>.

21. Foto de Eduardo Manchon por Wikimedia Commons, CC-BY-SA-3.0. Disponível em $<$ https:// commons.wikimedia.org/wiki/File:Arcos,_Pico_island_-_panoramio.jpg>. 



\title{
DA SINGULARIDADE DE UMA ILHA À DISTINÇÃO DE UMA PAISAGEM
}

\author{
MARIA DE JESUS MACIEL*
}

\begin{abstract}
Resumo: No contexto das nove ilhas dos Açores, o Pico é uma ilha jovem. Ilha de constituição geológica recente, moldada pelo homem e pelo fogo, forma paisagens únicas que se completam no mar e que implicariam múltiplos trabalhos. É uma ilha de paisagens de pedra, sobretudo a Oeste. Uma paisagem de lava improdutiva onde o homem construiu uma rede de currais, plantou vinha e fez brotar um bom vinho, apreciado e celebrado: o verdelho. A distinção da Paisagem da Cultura da Vinha da llha do Pico é a distinção de uma paisagem construída por gente com uma extraordinária capacidade de organização de trabalho. Gente com a beleza de alma que representa «o triunfo do homem sobre as forças brutas da

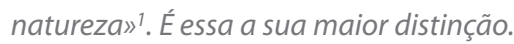

Palavras-chave: Açores; Ilha do Pico; Formação geológica e acção humana; Paisagem cultural da vinha e do vinho do Pico; Património Mundial.

\begin{abstract}
In the context of the nine islands of the Azores, Pico is a young island. Island of the recent geological constitution, shaped by man and fire, forms unique landscapes that are completed in the sea and that would involve multiple works. It is an island of stone landscapes, especially to the West. A landscape of unproductive lava where the man built a network of corrals, planted vines, and brought out a good wine, appreciated and celebrated: the verdelho. The distinction of the Pico Island Vineyard Culture Landscape is the distinction of a landscape built by people with an extraordinary capacity for work organization. People with the soul beauty that represents «the triumph of man over the brute forces of nature»². That is his biggest distinction.
\end{abstract}

Keywords: Azores; Pico island; Geological formation and human action; Cultural landscape of the Pico vineyard and vine; World Heritage site.

Uma paisagem que se impõe aos nossos olhos

e fascina-nos a ossatura despida de toda a carne, não pela impressão de monstruoso ou de atormentado, mas pela beleza intelectual, pela beleza superior e grave que é a das almas.

Raul Brandão, As Ilhas Desconhecidas ${ }^{3}$

\footnotetext{
* Investigadora do CITCEM. Email: maria.maciel@sapo.pt. A autora não segue o Acordo Ortográfico de 1990.

${ }^{1}$ BRANDÃO, 2011: 95.

2 BRANDÃO, 2011: 95. Tradução da autora.

${ }^{3}$ BRANDÃO, 2011: 107.
} 


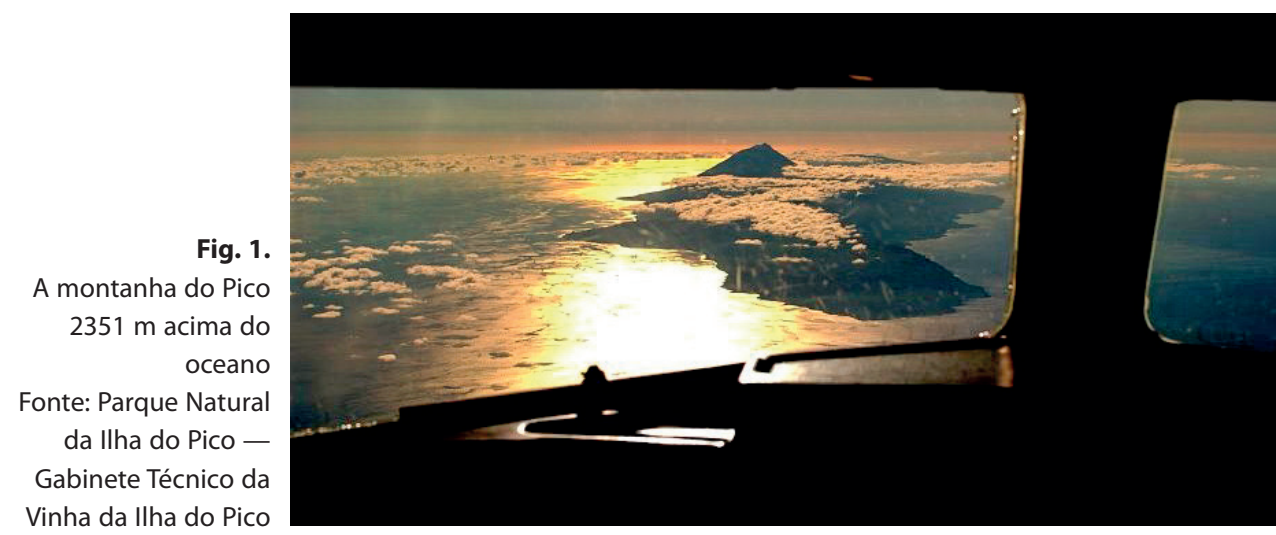

\section{UMA PAISAGEM MOLDADA PELO FOGO}

A Paisagem da Cultura da Vinha da Ilha do Pico é uma Paisagem Património assente na singularidade de uma ilha. Ilha que tem o nome da montanha que a distingue. Uma ilha num contexto de nove ilhas dispersas - os Açores -, que emerge na amplidão do mar - a parte mais visível da dorsal do Atlântico, situada entre o continente europeu e o americano - na junção de três placas tectónicas - a americana, a euro-asiática e a africana.

São, portanto, ilhas inscritas no mar largo, longe dos continentes que lhes fazem margem, ora próximas, ora distantes, ilhas que por vezes na sua dispersão formam grupos, embora sempre distintas entre si. Ilhas de um arquipélago de origem vulcânica que se reflecte numa rica e vasta paisagem, onde a geodiversidade e de biodiversidade representam um importante património.

Da originalidade que cada uma das ilhas do arquipélago possui, a ilha do Pico é entre todas a mais singular, e que de todas se distingue pela sua juventude, força e imponência da sua montanha. Uma ilha que

na sequência de um vulcanismo intenso ocorrido ao longo da sua história geológica, emergiu tardiamente do mar e foi adquirindo uma morfologia diversificada, que se pode agregar em três grandes domínios: (1) a Montanha do Pico, a ocidente, (2) o planalto da Achada que se desenvolve desde a Montanha até a extremidade $E$ da ilha e (3) o vulcão do Topo no lado sul... Os aspectos mais marcantes de cada uma destas áreas decorre do tipo de vulcanismo predominante que lhes está afecto ${ }^{4}$.

Como resultado, é uma ilha de múltiplas paisagens, de paisagens moldadas pelo fogo, queimadas pelos vulcões que, não só, em tempos antigos se sucederam, mas também em tempos históricos, quer contemporâneos do povoamento, quer mesmo 
séculos depois, que, em sequência obrigaram a um novo povoamento, em lugares de início preteridos. Uma paisagem a formar-se, numa contínua luta entre a força bruta da natureza que a fragilidade e a maleabilidade humana acabaram por dominar.

No desdobramento dessas paisagens geológicas em que se distingue uma grande e alta montanha, há picos e montes, crateras e lagoas, lajes e lajidos, morros e pontas, calhetas e calhaus, baías de calhau rolado, em que a areia só aparece pontual e esporadicamente, referenciando lugares como Areia Larga e a Prainha. Enfim, uma ilha que se prolonga a Ocidente num lastro enorme de lava.

\section{UMA PAISAGEM MOLDADA PELO HOMEM}

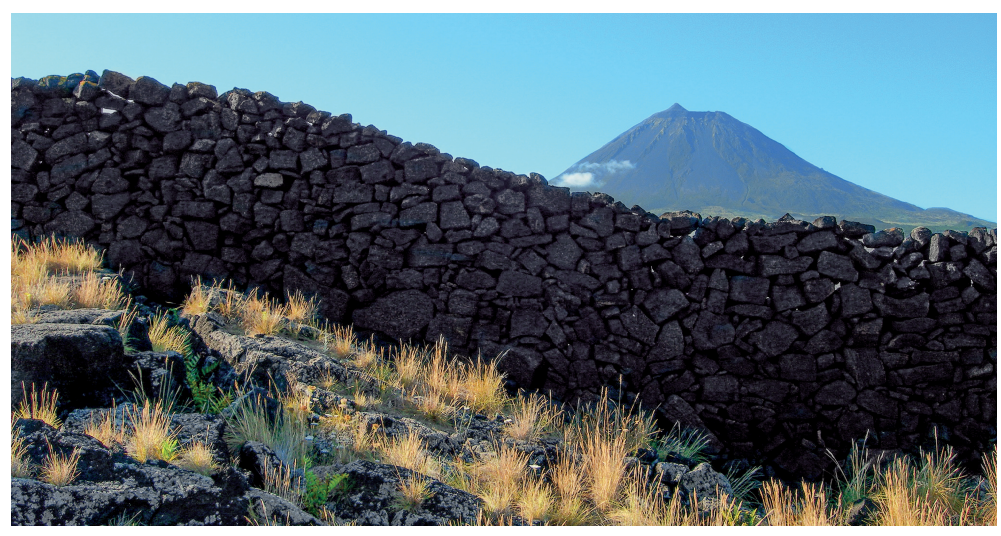

Fig. 2.

Pico - uma ilha de lava Fonte: Parque Natural da Ilha do Pico Gabinete Técnico da Vinha da llha do Pico

A ilha do Pico por ser a ilha de constituição geológica mais recente foi aquela que — à excepção da ilha do Corvo, mas por outras razões, — ofereceu mais dificuldades ao povoamento e, posteriormente a este, a uma luta contínua e diversificada pela sobrevivência. A tal ponto que até podemos perguntar se foi o homem que a moldou ou se foi ela, pela sua própria natureza que foi moldando o homem, à sua imagem e à sua força.

Os primeiros povoadores que um dia chegaram aos Açores viram-se confrontados com a nova realidade que se impunha, um ambiente muito diferente daquele que provinham, e no distanciamento de tudo, tiveram que criar condições para o seu enraizamento.

A vida na ilha do Pico acentuaria drasticamente essa verdade. Pela sua constituição geológica recente, apresentava características muito próprias que os obrigariam a um esforço maior. Decerto foi aquela que mais os desapontou, que mais dificuldades lhes ofereceu, pois, quando procuravam terras férteis para a cultura do trigo encontraram uma ilha de lavas, algumas bem recentes, que obrigaram a uma adaptação contínua e a uma luta enorme pela sobrevivência.

Das características desta ilha fala o nosso primeiro historiador Gaspar Frutuoso que a descreve no Livro Sexto das Saudades da Terra como «terra fragosa de biscoito, 
pedraria viva, e não tem mais terra que a que se faz das folhas das árvores [...] e, pelos biscoutos que, com o fogo que por muitas vezes tem arrebentado até agora [...] correram pela terra e cobriram grande parte dela» ${ }^{5}$.

O início do povoamento das ilhas dos Açores deu-se no reinado de D. Afonso $\mathrm{V}$, com gente do continente português, particularmente alentejanos, algarvios, gente da Beira e do Douro, e à falta dela, - num reino minguado de gente - com flamengos, sobretudo para povoar as ilhas «terceiras», ou seja, aquelas que na sua conjuntura formariam os grupos central e ocidental do arquipélago. O Pico foi a última ilha do grupo central a povoar, com um povoamento lento devido às características apresentadas.

Os povoadores distribuíam-se por vários estratos sociais, ou seja, arraia-miúda, alguns moiros, alguns judeus, tendo à sua frente, «meio cavaleiros, meio mercadores, que eram a nata da nossa burguesia», isto é, dos portugueses da segunda metade de Quatrocentos que "nada tinham dos portugueses que, cem anos depois, em plena febre de descobrimentos e conquistas, se lançariam a parasitar meio mundo» ${ }^{6}$.

Analisando este fenómeno, Nemésio chegaria até a afirmar que «os Açores são de facto um Portugal requintado porque receberam dêle a forma e o pensamento quando Portugal na verdade era uma fôrça em marcha» ${ }^{7}$.

Se a história mostra que os povoadores das ilhas estão ligados ao povo de onde vieram, indica também como se foram diferenciando destes pela necessidade constante de adaptação, ao viveiro insular. Por força das circunstâncias, desenvolveram, por vezes até ao limite, múltiplas capacidades onde sobrelevam a paciência, a resignação, a maleabilidade, a inventabilidade, a firmeza e uma tenacidade permanentes ${ }^{8}$. Competências mais que necessárias aos Homens do Pico, uma ilha onde era evidente a escassez de terra, a abundância de pedra e a falta de água.

$\mathrm{Na}$ contingência das ilhas e na presença do mar eterno, no isolamento de um meio limitado e restrito tiveram que se submeter à alimentação possível, tendo que tirar partido do que a terra lhes podia dar: «Come esta gente muito pouco pão por o não dar a terra; seu principal mantimento é abobras [...] dentabrum, raiz de erva [...] talos de funcho e nabos [...] e muitos figos e muito pescado.» ${ }^{9}$

Perante situações extremas, obrigaram-se a trabalhos vários na tentativa de desenvolver as potencialidades que a ilha lhes oferecia. Ilha que «Tem muito arvoredo: Cedro, pau branco, louro, faia, tamujo, urzes tão grandes como árvores, sanguinhos,

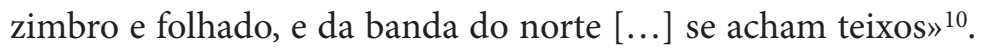

\footnotetext{
${ }^{5}$ FRUTUOSO, 1978: VI, 289, 304.

${ }^{6}$ NEMÉSIO, 1929: 9.

${ }^{7}$ NEMÉSIO, 1929: 18.

${ }^{8}$ Cf. NEMÉSIO, 1929: 8.

${ }^{9}$ FRUTUOSO, 1978: VI, 303.

${ }^{10}$ FRUTUOSO, 1978: VI, 303.
} 
Talvez por isso, tendo em conta tais premissas, no seu estudo sobre a açorianidade, Nemésio assevera que não podemos conceber um tipo de açoriano, mas sim dois ou três. Um dos tipos agrupa-se «em tôrno do habitante do Pico, que é, sob certo aspecto, a nata do insulano» ${ }^{11}$.

Continua a sua tese justificando que «tem outro feitio, outra ética $[\ldots]$ em verdade nenhum açoriano se lhe avantaja na concepção séria da vida, temperada embora por uma ingenuidade que é o segredo do seu triunfo nas lides a que se entrega» ${ }^{12}$.

\section{O HOMEM E O FOGO EM CONTRAPONTO}

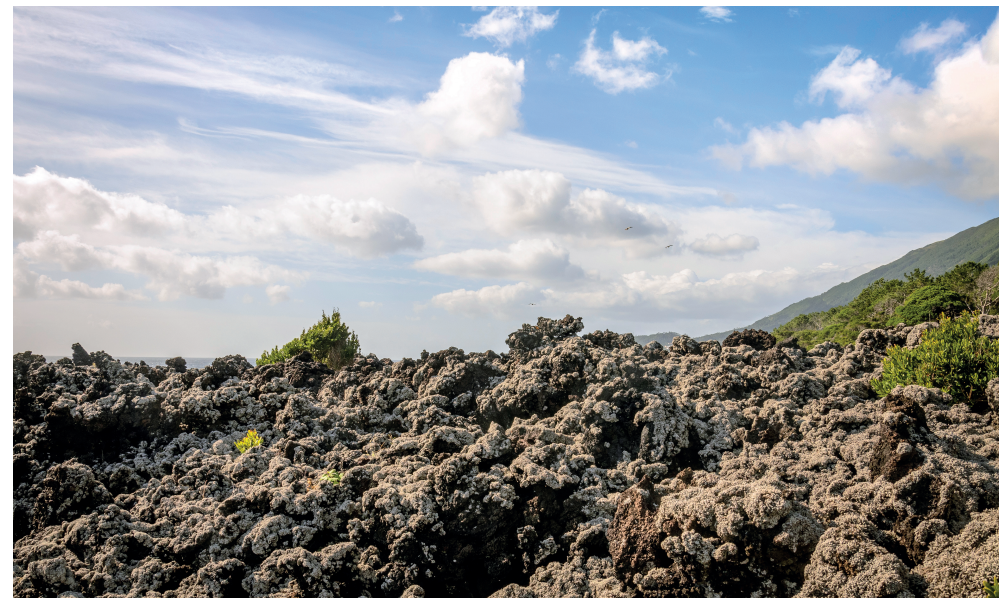

Fig. 3.

Formação lávica. Mistério de S. João, erupção de 1718 Fonte: Parque Natural da Ilha do Pico Gabinete Técnico da Vinha da Ilha do Pico

De uma ilha queimada pelo fogo Gaspar Frutuoso continua a falar:

«É toda a terra desta ilha mui áspera e muita parte dela coberta de biscouto» ${ }^{13}$, consequência do fogo que muitas vezes rebentou e que correu pela ilha e a cobriu de lava.

Mas não se ficaria por aqui. No século seguinte àquele que o historiador se refere, e outros posteriores, os seus habitantes seriam por vezes surpreendidos por novas erupções, dando origem a mais campos de pedra queimada e a todas as consequências daí resultantes.

Viveram em simultâneo com o fogo dos vulcões a queimar-lhe as casas e os campos, campos esses que criaram e organizaram aquando do povoamento. Depois do fogo se extinguir, houve que remodelar o restante e construir de novo. Aconteceu há 300 anos com as últimas erupções vulcânicas históricas de 1718-1719 e 1720 que afectaram as povoações de Santa Luzia e das Bandeiras, a Norte, de S. João e da Silveira, a Sul.

\footnotetext{
${ }^{11}$ NEMÉSIO, 1929: 12.

${ }^{12}$ NEMÉSIO, 1929: 14-15.

${ }^{13}$ FRUTUOSO, 1978: VI, 302.
} 


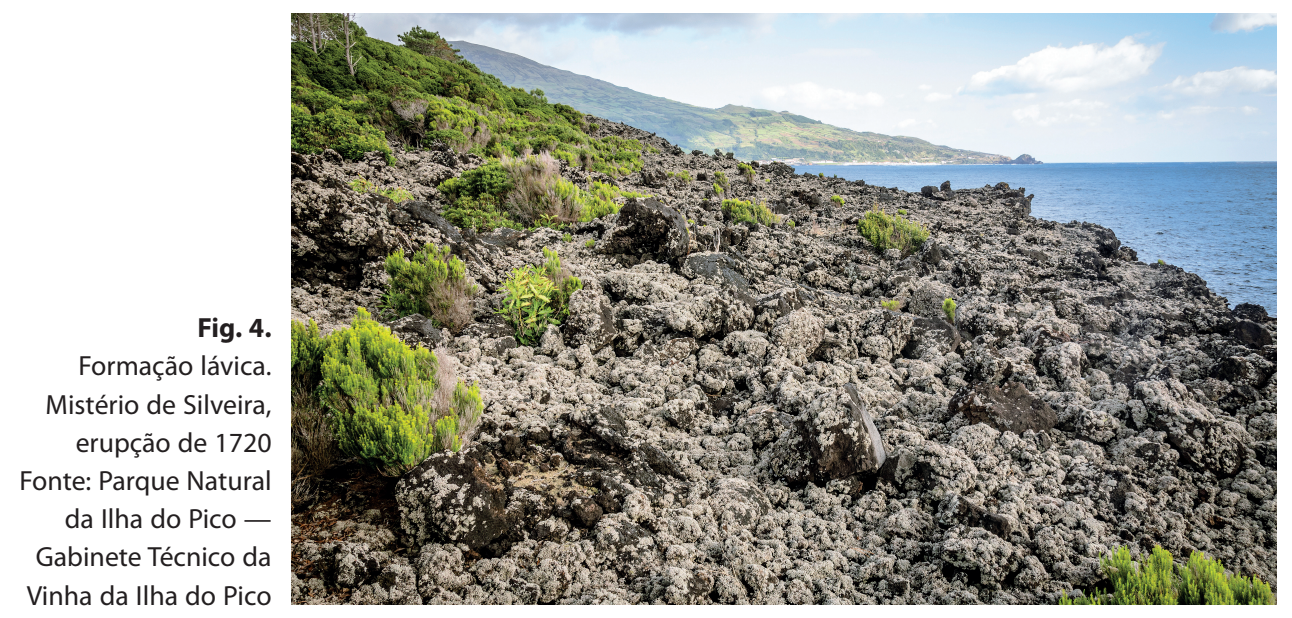

Com mais estas parcelas de terra queimada, Santa Luzia aumentaria os campos de lava, a acrescentar a uma terra de lajidos. A Sul, em particular S. João, houve que reconstruir a freguesia num novo espaço e modificar o seu modo de vida, explorando para o pastoreio as terras altas da ilha. Delas, os habitantes fizeram boas pastagens, protegidas e abrigadas pela montanha. Criaram a indústria de lacticínios, tornando-os pioneiros e exímios fabricantes de queijo e manteiga, que a partir de então ficaram - e são - conhecidos nas ilhas e no continente português.

Uma paisagem moldada pelo homem, por vezes em contraponto com o fogo, sempre pronto a inventar novas soluções perante tanta adversidade.

\section{UMA PAISAGEM QUE SE DESDOBRA NO MAR}

A ilha do Pico é constituída por múltiplas paisagens que o fogo e o homem foram moldando através do tempo na sua tentativa hercúlea de a modelar. E delinearam-na até às rochas do mar.

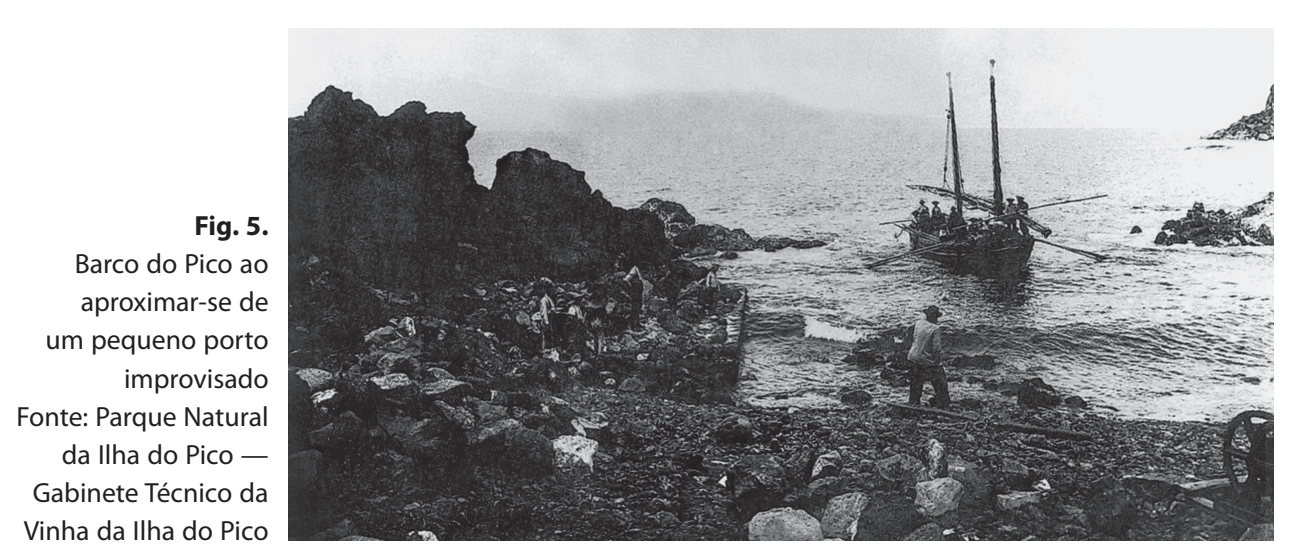


A luta desdobrou-se desde cedo em várias actividades que se prolongam no mar e no mar se completam. Houve que levar às outras ilhas e ao mundo o que a ilha possuía para complementar a carência de cereais. Assim, nas rochas negras do mar, o homem improvisou portos e portinhos e fez embarcadouros. Mais: foi ainda junto ao mar que abriu poços de maré, para ter água indispensável à vida de que a ilha carecia. Teve que ter vigor para dominar uma ilha de lavas recentes como teve que enfrentar o mar sempre presente e sempre necessário. Com persistência, resistência e arte dominou-a.

De tentativa em tentativa os habitantes tornaram-se exímios navegadores e, por fim, construtores dos seus próprios de barcos, que navegam nas ilhas, em particular para a mais próxima e para o mundo, escoando o que a terra dá, trazendo o que ela precisa.

A presença do mar é tão marcante que leva Nemésio a afirmar: «Como as sereias temos uma dupla natureza: somos de carne e pedra. Os nossos ossos mergulham no mar.» ${ }^{14} \mathrm{E}$ nesse aspecto, distingue o homem do Pico que «está sempre pronto para saltar à canoa à saga da baleia. É êste o seu destino no mundo, o seu comêço e o seu fim» ${ }^{15}$.

Toda essa relação fortíssima com o mar marca presença hoje, e para o futuro, no Museu dos Baleeiros nas Lajes do Pico.

\section{O VINHO NUMA PAISAGEM DE LAVA}

A vinha e o vinho vieram na mente dos primeiros povoadores das ilhas desde logo despertos para experiências vitivinícolas nas ilhas então descobertas e a povoar. A terra para lavrar era tão escassa no Pico, particularmente na zona Oeste onde predominavam os campos de lava, que tiveram de procurar outras formas de subsistência. Era crucial essa atitude.

Atendendo às fontes orais, coligidas pelos cronistas, foi por intermédio dos frades franciscanos instalados no Faial que possuíam propriedades na ilha do Pico que, no início do povoamento, foram introduzidos alguns bacelos oriundos do Chipre e da Madeira. Segundo fontes citadas por Frei Diogo das Chagas ${ }^{16}$ teria sido o primeiro vigário da ilha, Frei Pedro Álvares Gigante, o introdutor da vinha no Pico.

Se o terreno era propício - ilha moldada pelo fogo, ilha coberta de lava que "ficou com aquela pedra mais quente, pera criar muito arvoredo e vinhas» ${ }^{17}$, possuía também um clima favorável, mais quente e menos húmido. Tanto que nos séculos seguintes aos do povoamento - XVI e XVII - as terras encontravam-se já cobertas de vinhedos, nas zonas de um primeiro povoamento, nomeadamente, a Sul, Santa Bárbara e Santa Cruz das Ribeiras e a Norte na vila de S. Roque do Pico.

\footnotetext{
${ }^{14}$ NEMÉSIO, 1986: 407.

${ }^{15}$ NEMÉSIO, 1929: 15.

${ }^{16}$ CHAGAS, 1989: 256.

${ }^{17}$ FRUTUOSO, 1978: VI, 304.
} 
Gaspar Frutuoso acompanha o acontecimento e acentua: «Em toda a terra há muitas vinhas, que dão bom vinho, e melhor que em todas as ilhas.» ${ }^{18}$

Como a plantação da vinha teve sucesso estendeu-se a toda a ilha ocupando particularmente os lugares onde a lava predominava, pois devido à sua aridez e à consequente improdutividade não eram propícios a outras culturas.

Com características geoclimáticas propícias foi preciso criar um método para defender a plantação dos vinhedos das intempéries, utilizando a pedra solta que por toda a ilha existia, particularmente na zona Oeste, naquele descampado coberto de lava. Assim se formou uma rede de currais, protegendo a vinha do rocio do mar e dos ventos marítimos que o acicatam e que destroem as culturas. Para o sucesso da viticultura foi ainda fundamental a criação de uma rede de estruturas complementares feitas também de pedra, como os lagares, alambiques e adegas que de modo geral pertenciam às casas solarengas dos grandes proprietários. Houve que investir num bem essencial, então muito escasso, a água, criando poços de maré, assim como talhando na rocha pequenos portos para exportar o vinho e outros produtos.

Com certeza que «a endémica esterilidade cerealífera terá constituído um estímulo para que os investimentos agrícolas fossem direccionados para outros produtos, neste caso o vinho, complemento importante da dieta mediterrânica» ${ }^{19}$, produtos como o vinho, a água-ardente e a fruta garantiam uma viabilização comercial para a aquisição de cereais.

A dura luta pela sobrevivência fez germinar naquelas pedras negras um vinho por muitos apreciado e celebrado. Cantado nas voltas alegres da Chamarrita: «Esta Chamarrita nova, esta nova Chamarrita, bem cantada bem bailada, não há outra mais bonita.» E enquanto alegres bailavam, no despique das cantigas ao desafio, elogiavam o bom vinho, cantando:

Este vinho é bom vinho
É dado na cepa torta
A uns faz perder o tino
A outros errar a porta ${ }^{20}$.

Vinho celebrado pelos poetas como Garrett que o cantou na sua fase arcádica «o rescendente Pico», como refere Vitorino Nemésio, confessando que «fui prová-lo pela última vez, vai já para vinte anos, no Alto da Nespereira, no Minho, em casa de Raul Brandão, que ostentava aquele lacre como um troféu da sua pessoal descoberta das Ilhas Desconhecidas» ${ }^{21}$.

\footnotetext{
${ }^{18}$ FRUTUOSO, 1978: VI, 303.

${ }^{19}$ COSTA, 1997: 195.

${ }^{20}$ Cantiga da Chamarrita, baile tradicional que expressa toda a vivacidade da gente do Pico.

${ }^{21}$ NEMÉSIO, 1998: 107.
} 


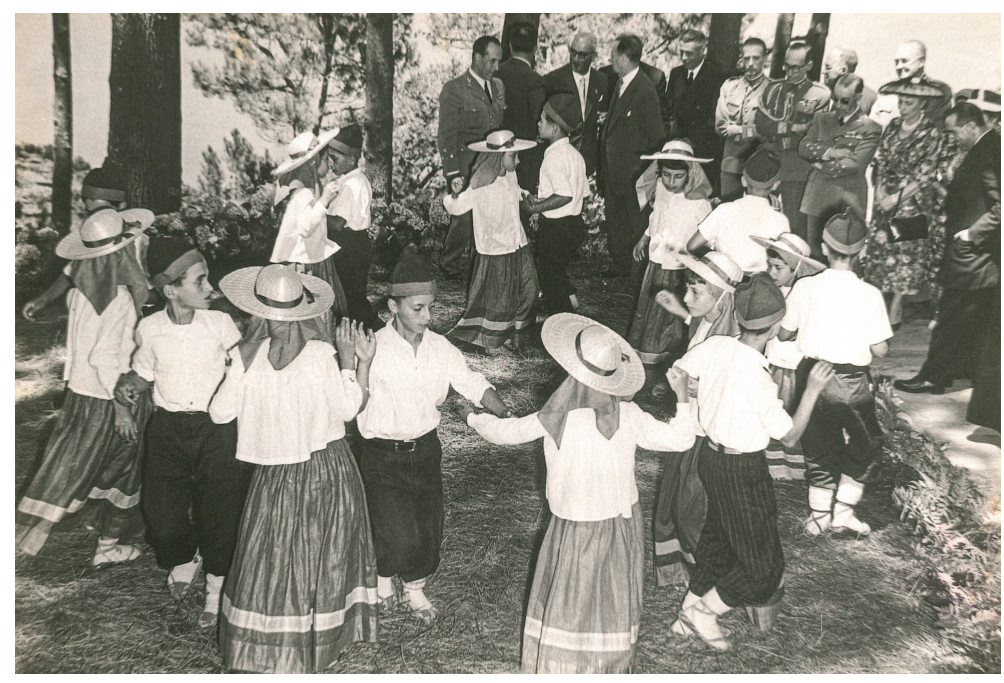

Fig. 6.

A Chamarrita bailada por grupo de crianças da Escola Primária de S. João em S. Miguel Arcanjo, Pico, 1957, na visita presidencial de Craveiro Lopes Fonte: Fototeca Nacional - Palácio Foz, Lisboa. 54.155

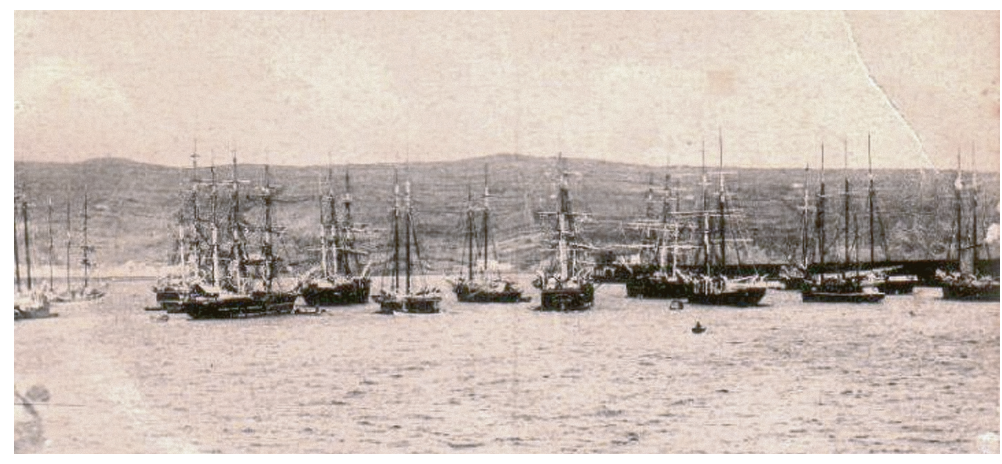

Fig. 7.

Embarcações estrangeiras no Porto da Horta, ilha do Faial (século XIX) Fonte: Parque Natural da Ilha do Pico Gabinete Técnico da Vinha da Ilha do Pico

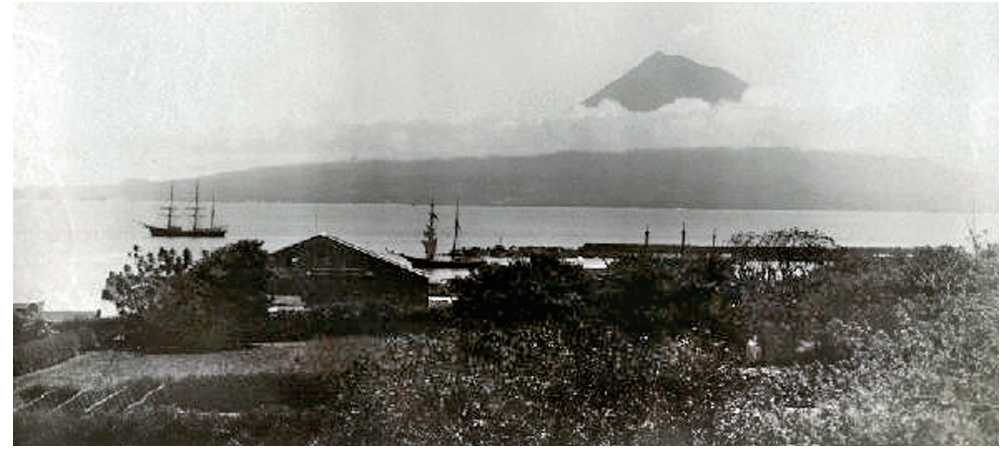

Fig. 8.

Vista para o canal Faial-Pico Fonte: Parque Natural da Ilha do Pico Gabinete Técnico da Vinha da llha do Pico

Contudo, este famoso verdelho, a partir de meados do século XIX, não resistiu às pragas, sobretudo à filoxera que ditou o fim de um ciclo económico, mas não o termo das experiências vitivinícolas, apesar de todas as vicissitudes, contratempos e mudanças que se sucederiam. 
O caminho percorrido outrora continua hoje a motivar novas experiências. Ensaios que vão a bom ritmo, com vinhos de qualidade. Vinhos que espelham a história de uma ilha, ostentando nomes sugestivos e indicativos da história vitivinícola, ao longo do tempo. Entre eles Frei Gigante, Terras de Lava, Lajido, Maroiço, Curral Atlantis e ainda o célebre Czar, a lembrar o vinho verdelho que os veleiros ingleses levavam para a corte da Rússia.

\section{A DISTINÇÃO DE UMA PAISAGEM, A DISTINÇÃO DE UMA GENTE}

Numa ilha coberta de lavas, já Raul Brandão vira «uma beleza nova que é preciso encontrar - mas depois de encontrada, nunca mais nos larga...»22 Uma ilha que se impõe "pela beleza superior e grave que é a das almas»" ${ }^{23}$.

Ilha povoada por gente cheia de tenacidade e de espírito de luta que mais tarde sensibilizaria Nemésio ao ponto de dizer: «A impressão dominante em quem visita esta gente [...] É o milagre da organização do trabalho e da estrutura social ao mesmo tempo inflexível e extraordinariamente plástica.» ${ }^{24}$

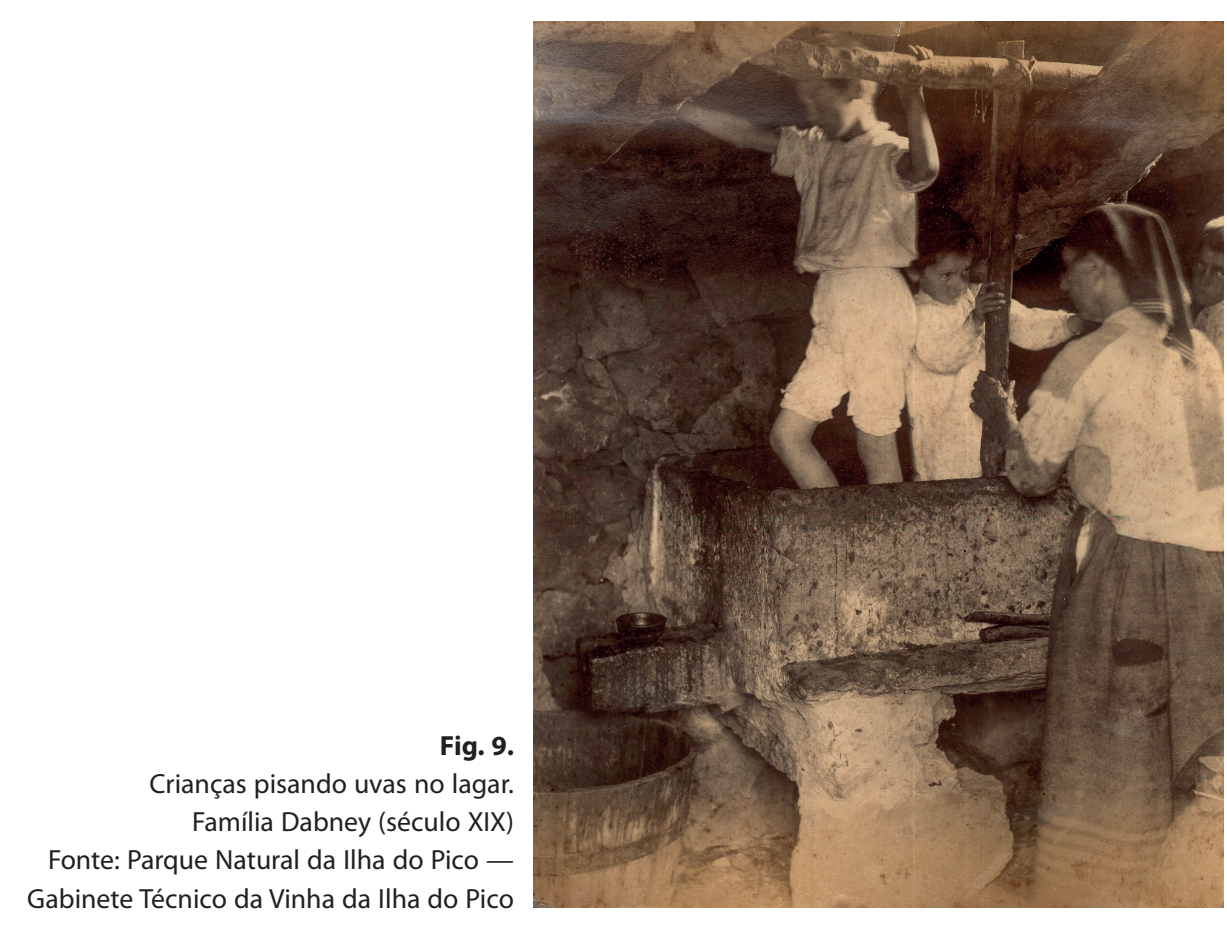

\footnotetext{
${ }^{22}$ BRANDÃO, 2011: 108.

${ }^{23}$ BRANDÃO, 2011: 107.

${ }^{24}$ NEMÉSIO, 1998: 108.
} 


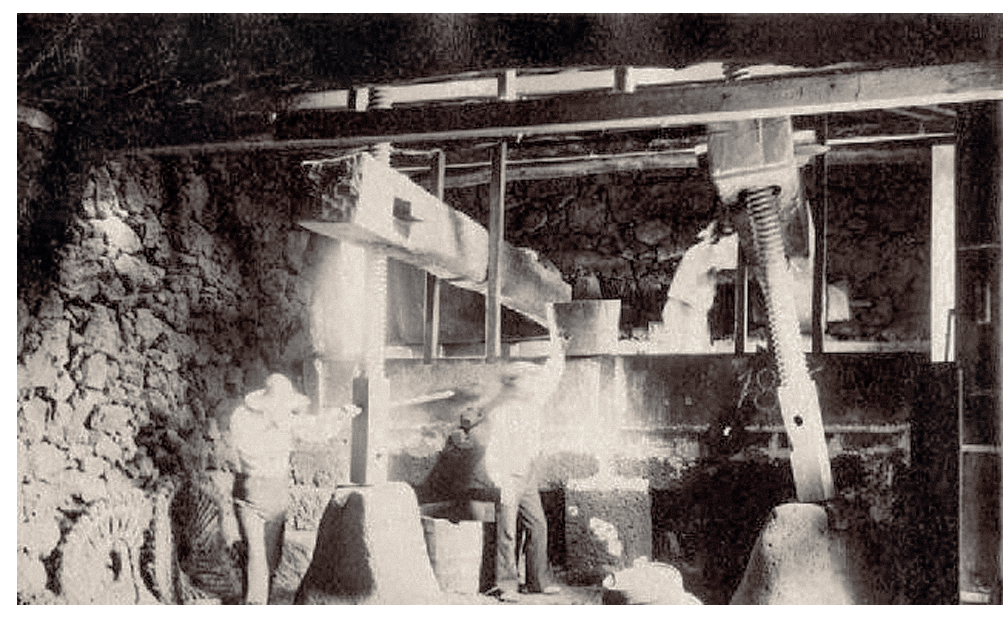

Fig. 10.

Espremendo uvas no lagar. Família Dabney (século XIX)

Fonte: Parque Natural da llha do Pico Gabinete Técnico da Vinha da llha do Pico

Foi esse milagre da organização do trabalho e a capacidade de o fazer em situações limite que cobriu toda a ilha de muros, alguns de grande extensão que formam caminhos do mar à serra. Que sustentou vários ciclos económicos. Que o levou a enfrentar o mar, porque foi necessário viver dele e através dele. Que fez brotar, num grande lastro de lava, um delicioso vinho.

E para que a vinha e o vinho germinassem naquele descampado de lava, as mãos humanas criaram uma paisagem de grande valia, única e universal que representa «o triunfo do homem sobre as forças brutas da natureza» ${ }^{25}$ : a Paisagem da Cultura da Vinha da Ilha do Pico, integrada, em 2004, como Paisagem Cultural nos bens do Património Mundial da UNESCO.

Paisagem que cativa o nosso olhar. E que a ilha prolonga numa multiplicidade de paisagens de um passado poderoso em termos geológicos e humanos, que se desdobra a cada esquina da nossa história e nos vai contando o que o fogo e a mão do homem edificaram.

Devido ao «excepcional exemplo de adaptação das práticas agrícolas a um ambiente exigente» e através de «açcões que protegem a geodiversidade, a biodiversidade e o património cultural e promovem uma arquitetura integrada», a Paisagem da Cultura da Vinha da Ilha do Pico obteve esta honrosa distinção.

Em 2019, a Paisagem da Cultura da Vinha da Ilha do Pico foi distinguida com o primeiro prémio na categoria de «Melhor Desenvolvimento de uma Paisagem Cultural de Relevância Europeia» dos European Garden Awards. Numa cerimónia realizada na Fundação Schloss Dick, na Alemanha, recebeu o prémio o director do Parque Natural da Ilha do Pico e do Gabinete Técnico da Paisagem da Cultura da Vinha da Ilha do Pico, Manuel Paulino da Costa que aí esteve presente.

${ }^{25}$ BRANDÃO, 2011: 95. 


\section{FONTES}

Arquivo dos Açores (1878-1959). Ponta Delgada: Universidade dos Açores, 1980-1984. 15 vols. Edição fac-similada da edição original.

\section{BIBLIOGRAFIA}

BRANDÃO, Raul (2011). As Ilhas Desconhecidas - Notas e Paisagens. Lisboa: Quetzal Editores.

CHAGAS, Frei Diogo das (1989). Espelho Cristalino em Jardim de Várias Flores. Angra do Heroísmo: SREC. CORDEIRO, Padre António Cordeiro (1981 [1717]). História Insulana das Ilhas a Portugal Sujeitas no Oceano Ocidental. Angra do Heroísmo: SREC. Edição fac-similada da edição de 1717.

COSTA, Ricardo Manuel Madruga da (1998). Nas rotas do Verdelho e outras evocações. On the Verdelho Route and the other evocations. São Roque: Publiçor.

COSTA, Susana Goulart (1997). Pico. Séculos XV-XVIII. Lajes do Pico: Associação de Municípios da Ilha do Pico.

DUARTE JÚNIOR, Tomaz (2001). O Vinho do Pico. [Ribeira Grande]: [Coingra, Lda.].

FRANÇA, Zilda Terra Tavares de Melo de (2002). Origem e evolução petrológica e geoquímica do vulcanismo da Ilha do Pico - Açores. São Roque do Pico: Câmara Municipal de S. Roque do Pico.

FRUTUOSO, Gaspar (1978). Livro Sexto das Saudades da Terra. Ponta Delgada: Instituto Cultural de Ponta Delgada, livro VI.

GUERRA, Rodrigo (1980). A Americana. Angra do Heroísmo: DRAC. (Coleção Gaivota; 8).

LARANJO, João Augusto (1927). O Pico. «Brotéria». Número especial sobre agricultura, 32-53.

MACEDO, António Lourenço da Silveira (1981 [1871]). História das Quatro Ilhas que formam o distrito da Horta. Angra do Heroísmo: SREC. 3 vols. Edição fac-similada da edição de 1871.

MENESES, Avelino Freitas de (1998). O Município da Madalena (Pico), subsídios para o seu estudo. Madalena: Câmara Municipal da Madalena.

NEMÉSIO, Vitorino (1929). O Açoriano e os Açores. [Porto]: Renascença Portuguesa.

NEMÉSIO, Vitorino (1986). Açorianidade. In GOUVEIA, Margarida, intro. e org. Vitorino Nemésio Estudo e Antologia. Lisboa: Instituto da Cultura e Língua Portuguesa, pp. 406-407.

NEMÉSIO, Vitorino (1998). Corsário das Ilhas. 3. a ed. Lisboa: Imprensa Nacional-Casa da Moeda. (Obras Completas de Vitorino Nemésio; XVI. Jornal de Vitorino Nemésio; 3).

NEMÉSIO, Vitorino (2014). Mau Tempo no Canal. Santa Maria da Feira: Relógio D’Água.

RAVINA, Agustin Guimera (1986). Las islas del vino (Madeira, Azores y Canarias) y la America inglesa durante el siglo XVIII: una aproximacion a su estúdio. In Coloquio Internacional da Madeira, 1986. Funchal: Direção Regional da Cultura, vol. II, pp. 900-934.

ROSA, Nunes da (1998). Madrugada entre ruínas. Horta: Câmaras Municipais do Triângulo.

SANTA RITA, António José Vieira (1867). Relatório apresentado pelo governador civil do districto administrativo da Horta António José Vieira Santa Rita, à Junta Geral do mesmo Distrito na sessão ordinário de 1867. Horta: Typ. Hortense.

SILVA Manuel Ribeiro da (1951). A Ilha do Pico sob o ponto de vista vitivinícola. «Boletim da Comissão Regularizadora dos Cereais do Arquipélago dos Açores». XIV, 45-58.

SOUSA, João Soares de Albergaria e (1995). Corografia Açórica: descrição física política e histórica dos Açores. Ponta Delgada: Jornal de Cultura. Primeira edição: 1822.

SOUSA, Paulo Silveira e (2004). Para uma história da vinha e do vinho nos Açores. «Boletim do Instituto Histórico da Terceira». LXII, 115-217.

VELOSO, Ana Luísa (1988). A Ilha do Pico e a paisagem dos muros negros. Horta: Direção Regional de Turismo.

\section{WEBGRAFIA}

http://siaram.azores.gov.ptpatrimónio/cultural/vinhas-pico/intro.html 
5

$$
\begin{array}{r}
\text { VALORIZAÇÃO E } \\
\text { SUSTENTABILIDADE DO } \\
\text { PATRIMÓNIO VITIVINICCOLA } \\
\text { HISTÓRICO-CULTURAL } \\
\text { DOS TERRITÓRIOS } \\
\text { DO PICO E DO DOURO }
\end{array}
$$





\title{
MUSEUS DO PICO
}

\author{
MANUEL FRANCISCO COSTA JR.*
}

\begin{abstract}
Resumo: Apresentação do Museu Regional do Pico nas suas três extensões: o Museu dos Baleeiros, na vila das Lajes do Pico, o Museu da Indústria Baleeira, na vila de São Roque do Pico e o Museu do Vinho, na vila da Madalena, profundamente ligados à geografia e história únicas da ilha, com destaque para o Museu do Vinho, emanação cultural e patrimonial da principal atividade económica exercida pela comunidade que ocupou este território desde o seu povoamento. Este museu reúne as memórias e tecnologias agrícolas associadas ao vinho num espaço que, durante séculos, foi dedicado ao fabrico do vinho: as instalações agrícolas que pertenceram ao Convento do Carmo - imóvel dos séculos XVII-XVIII, mansão de veraneio dos frades carmelitas sedeados na cidade da Horta -, símbolo arquitetónico da fase opulenta do Ciclo do Vinho Verdelho, na ilha do Pico.
\end{abstract}

Palavras-chave: Museu do Vinho; Museus regionais; Paisagem Cultural da Vinha da Ilha do Pico; Património Mundial (UNESCO).

\begin{abstract}
Presentation of the Regional Museum of Pico in its three extensions: the Whaling Museum, in the town of Lajes do Pico, the Whaling Industry Museum, in the town of São Roque do Pico, and the Wine Museum, in the town of Madalena, deeply linked to geography and unique history of the island, with emphasis on the Wine Museum cultural and heritage emanation of the main economic activity exercised by the community that has occupied this territory since its settlement. This museum brings together the memories and agricultural technologies associated with wine in a space that, for centuries, was dedicated to the manufacture of wine: the agricultural facilities that belonged to the Convento do Carmo immovable, from the 17th to 18th centuries, a summer mansion for the Carmelite friars based in the city of Horta -, architectural symbol of the opulent phase of the Verdelho Wine Cycle, on the island of Pico.
\end{abstract}

Keywords: Wine Museum; Regional museums; Cultural Landscape of the Pico Island Vineyard; World Heritage (UNESCO).

O Pico é uma espécie de outro mundo que não é do nosso mundo. Ilha austera, esfíngica, primordial, e fortemente telúrica, remete-nos para uma certa essência fundacional daquilo que fomos e daquilo que somos. Medularmente rural, possui um magnetismo próprio, forjado na seiva dos vulcões, que se apega aos nossos sentidos, como lapa à pedra.

Ilha geologicamente jovem, de semblante cinza e negro, e com uma beleza que é só dela, e a torna única no contexto insular, o Pico é o grande panteão vulcânico dos Açores. A única ilha que tem uma das «7 Maravilhas de Portugal», a Montanha do Pico, a namorar uma Paisagem Mundial da UNESCO, a Paisagem da Cultura da Vinha da Ilha do Pico, que aqui celebramos.

O Pico reflete o exemplo acabado da ação da geografia sobre o curso da história, realidade que determinou a individualização do modo de vida das suas gentes. Com

\footnotetext{
* Diretor do Museu do Pico.
} 
efeito, a infertilidade do solo, de «lajido», de «mistério» e de «biscoito», atrasou a ocupação humana e dificultou o desenvolvimento económico. No entanto, esta maldição da terra — apenas 3/4\% do solo é arável — aguçou o engenho e a tenacidade dos Homens.

A vocação vinícola constituiu-se, assim, como o principal elemento diferenciador do Pico na paisagem agrícola dos Açores. A paisagem da Cultura da Vinha da Ilha do Pico, classificada como Património Mundial da UNESCO, corresponde a uma área de excecional beleza natural e importância estética, obedecendo a uma evidente relação de equilíbrio e cumplicidade entre o homem e a natureza, ao longo dos séculos, desde o povoamento à atualidade.

A criação do Museu do Vinho, na vila da Madalena, deve, pois, ser entendida como uma inevitabilidade histórica. A organização de um museu subordinado à temática da vinha e do vinho identifica-se com a principal atividade económica exercida pela comunidade que ocupou este território, desde o seu povoamento. Na Madalena reúnem-se, de facto, várias condições favoráveis para se instalar um museu de memórias e tecnologias agrícolas associadas ao vinho, quer pela extensão e expressão da vinha que domina o território, quer pela existência de um espaço que, durante séculos, foi dedicado ao fabrico do vinho: as instalações agrícolas que pertenceram ao Convento do Carmo. Este imóvel, de finais do século XVII, inícios do século XVIII, mansão de veraneio dos frades carmelitas sedeados na cidade da Horta, é um dos símbolos arquitetónicos da fase opulenta do Ciclo do Vinho Verdelho, na ilha do Pico.

A localização geográfica privilegiada do Museu do Vinho, o poder mágico da paisagem natural - a vinha, os dragoeiros seculares, o canal, o mar e a Montanha - , a dimensão poética e estética do lugar, a presença de uma arquitetura secular, de pedra vulcânica, em harmonia com a nova arquitetura de Paulo Gouveia, têm vindo a transformar este espaço em lugar de visita turística obrigatória, lugar de memória e de culto, lugar de estudo, lugar de história natural.

Figs. 1 a 10. Museu do Pico (exterior e interior). Fonte: Museu do Pico
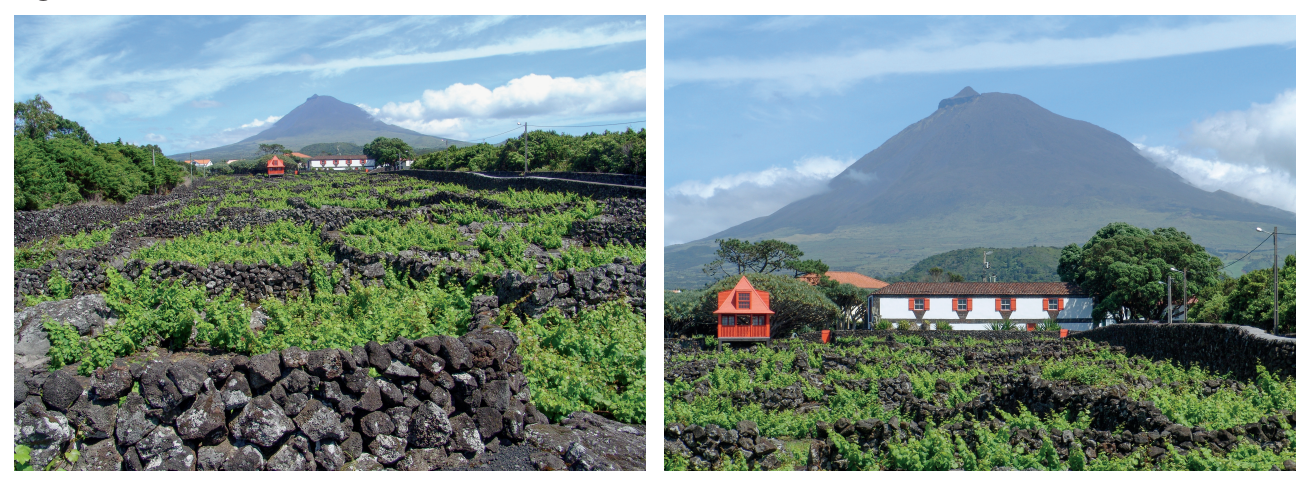

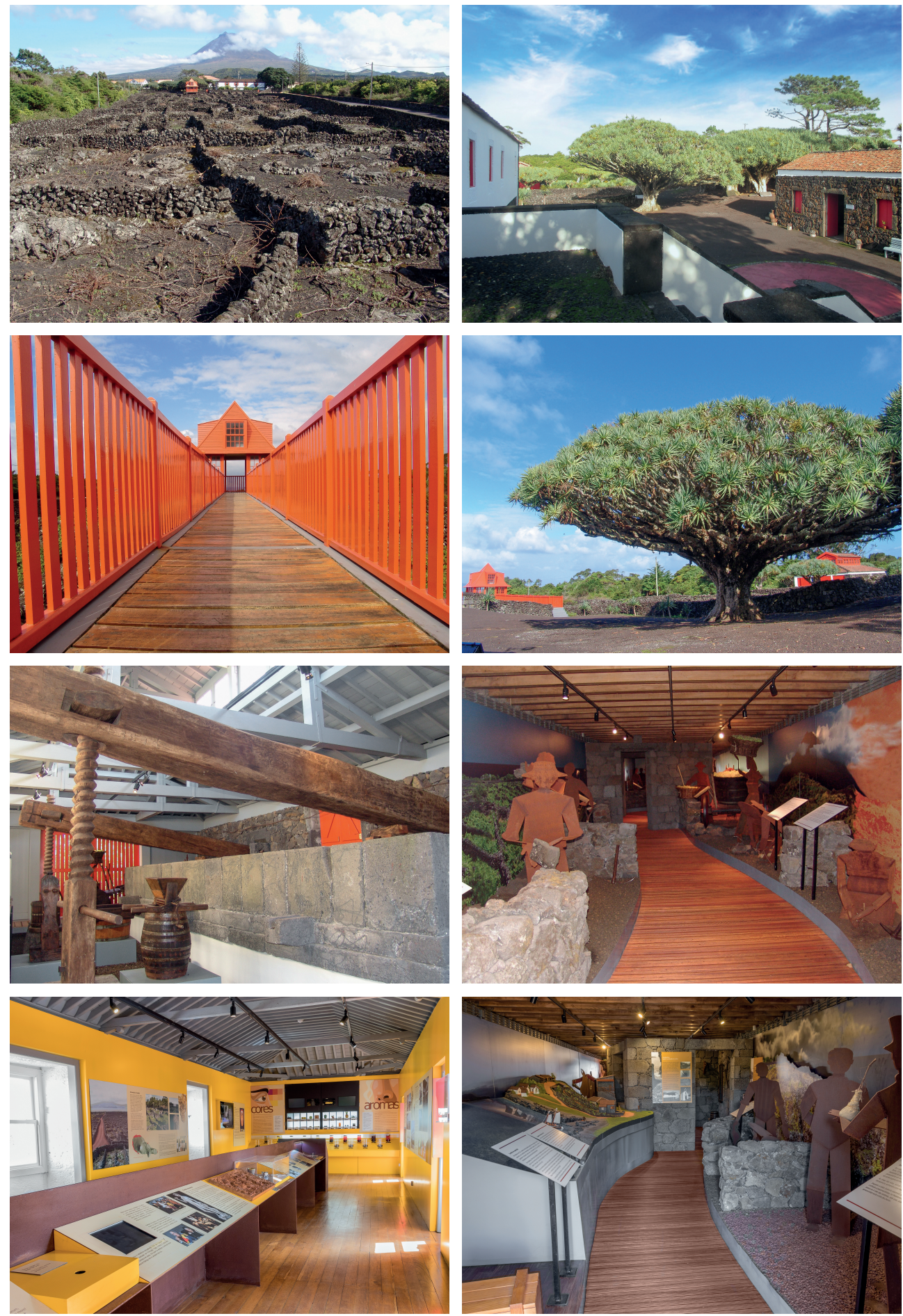
Nos museus do Pico enxertaram muitas empresas, serviços, agentes culturais e económicos, instituições, projetos, iniciativas, programas e eventos. Públicos e privados. Locais, regionais, nacionais e internacionais. Aqui, os museus foram sempre lugares de romaria e de peregrinação cultural, santuários de celebração da ilha e do arquipélago.

Mesmo dessacralizados, porque trespassados por uma visão contemporânea das funções museológicas, estes museus são espaços onde, com impurezas e imperfeições, nos deciframos e interpretamos.

Neles habitam narrativas locais e regionais, que são globais. Histórias e epopeias que são do mundo. Aqui mora o singular, o que é único. O que tem carácter e forte personalidade. Unicidade e singularidade que desaguam, sem contrafortes, na universalidade. É essa diferença, essa especificidade, sem mimetismos, que constitui, e há de sempre constituir, a nossa força e a nossa atratividade.

Com a noção clara de que só a diferença, e a defesa intransigente do que é nosso, num mundo aberto, nos pode transformar num espaço de verdadeira comunhão cultural e patrimonial, com grande potencial turístico. Precisamos de ser sempre nós, de corpo inteiro, a partir de dentro. Sem recusarmos a vocação universal que nos está na massa do sangue da história. Sem copiar o mundo.

Fomos capazes de, a partir de nós, com limitações e defeitos, construir um conceito de museu que se transformou numa imagem de marca no panorama museal e turístico da Região. Desde sempre liderámos a procura turística nos Açores. Em 2018 tivemos 65103 visitantes. Em fevereiro de 2019 atingimos, no conjunto dos três polos museológicos, 1037623 visitantes.

Fizemo-lo em rede, e em complementaridade com os agentes sociais e culturais locais. Sem centralismos estéreis, sem elitismos provincianos, em respeito absoluto pela comunidade e pelo território. Estabelecendo parcerias, cumplicidades, solidariedades. Percebendo que o museu projeta a comunidade, e esta se deve rever no seu museu. Promovendo ligações e associações de todo o tipo com as mais variadas entidades públicas e privadas da ilha e dos Açores.

Percebemos, para melhor nos defendermos e sermos mais eficazes, que precisávamos de trabalhar com todos. Promovemos um diálogo estratégico com os vários serviços governamentais e com os municípios da ilha. Aproximámo-nos dos agentes turísticos. Em permanente diálogo, ajustámos mecanismos e procedimentos de procura e de funcionamento. Associámo-nos, em regime de parceria, apoio e colaboração, a várias entidades sociais e culturais: núcleos museológicos, espaços de memória, centros de interpretação, coletividades, agremiações e sociedades (casas do povo, filarmónicas, grupos corais, grupos de cantares, grupos folclóricos, grupos de teatro). Reforçámos a nossa ligação às escolas, às paróquias, às Santas Casas da Misericórdia. 
Estimulámos e acompanhámos inúmeros projetos de investigação científica em torno da cultura da baleação e da cultura da vinha e do vinho. Regionais, nacionais e estrangeiros. Desenvolvemos, a partir do território, da comunidade e das nossas coleções, ações de identificação, estudo, preservação e divulgação do património imaterial dos Açores. Aproximámo-nos das populações. Resgatámos ofícios, profissões, saberes, experiências e técnicas tradicionais. Levantámos e contámos histórias de vida. Produzimos centenas de atividades culturais, muitas delas em colaboração estreita com os agentes culturais locais. Estabelecemos parcerias com os artesãos e as empresas de artesanato. Acolhemos e apoiámos jornais, revistas, programas radiofónicos e televisivos, projetos fílmicos, iniciativas de investigação, de todo o mundo. Mantivemos e reforçámos a nossa relação com museus nacionais e estrangeiros, trocando saberes, experiências e produtos culturais.

Criações populares, em sentido puro, os museus do Pico têm sabido opor-se, com sucesso, à vulgaridade e à redundância museológica, à erosão da herança tradicional, e à massificação cultural. Por isso, como emanações cénicas e identitárias do território e da comunidade, condensam uma espécie de essencialidade insubornável da ilha e do arquipélago.

Convocam, no grande palco da terra e do mar, a voz, nua e crua, das mulheres e dos homens da ilha: os «seus contrabandos originais», as suas fomes e medos ancestrais, as suas epopeias de sobrevivência, a sua vontade sísmica, a sua resiliência vulcânica, a sua necessária, indesejada e mítica heroicidade. 



\title{
O MUSEU DO DOURO: PERSPETIVAS DE UM MUSEU DE TERRITÓRIO
}

\author{
NATÁLIA FAUVRELLE*
}

\begin{abstract}
Resumo: Neste artigo pretende-se dar a conhecer o Museu do Douro, situado na cidade de Peso da Régua, enquanto equipamento cultural fundamental para o conhecimento dos diferentes patrimónios da Região Demarcada do Douro. Trata-se de um museu de território associado a esta região vitivinícola, cuja paisagem é Património Mundial. Começa-se por caracterizar o Museu, enquadrando brevemente o processo de instalação e as características desta estrutura, particularizando os espaços mais importantes que a compõem.

Partindo da lei da criação do museu, discutem-se alguns aspectos entre aquilo que é a legislação e a realidade territorial e museológica, considerando os desafios que daqui emergem e o modo como o Museu tem procurado equilibrar o seu papel de mediador cultural de uma região e a sua própria sustentabilidade enquanto projeto.
\end{abstract}

Palavras-chave: Museu do Douro; Peso da Régua; Região Demarcada do Douro; Alto Douro Vinhateiro.

\begin{abstract}
In this article, we discuss the Douro Museum, located in the city of Peso da Régua, cultural equipment which is fundamental for the knowledge of the different types of the heritage of the Douro Demarcated Region. It is a museum of territory associated with this wine region, whose landscape is a World Heritage site. We begin by characterizing the Museum, briefly framing the installation process and the characteristics of this equipment, particularizing the most important spaces that compose it.

Starting from the law of the creation of the museum, some aspects are discussed between what is the legislation and the territorial and museological reality, considering the challenges that emerge from here and the way the Museum has tried to balance its role as cultural mediator of a region and its own sustainability as a project.
\end{abstract}

Keywords: Douro Museum; Peso da Régua; Demarcated Douro Region; Alto Douro Wine Region.

O Museu do Douro, com sede em Peso da Régua, foi desde a sua génese pensado como um museu de território, centrando-se num espaço vocacionado para a vitivinicultura, a Região Demarcada do Douro, algo excecional no contexto museológico nacional. A sua missão é reunir, conservar, identificar e divulgar o património museológico e documental disperso por esse território, constituindo-se como um instrumento ao serviço do desenvolvimento sociocultural desta região. Numa perspetiva de museologia de comunidade, o Museu do Douro assume-se como um processo cujo desenvolvimento deverá envolver a colaboração ativa com as instituições locais, regionais e internacionais.

\footnotetext{
* Coordenadora dos Serviços de Museologia do Museu do Douro; investigadora do CITCEM. Email: natalia.fauvrelle@ museudodouro.pt.
} 
As primeiras reflexões sobre a necessidade de criar um museu para salvaguardar o património da região do Douro, acumulado pela atividade dos lavradores durienses ao longo dos séculos, por forma a valorizá-lo e divulgá-lo, registam-se por volta dos anos 30 do século XX. Estas ideias estavam então em voga, enquadrando-se naquilo que foi difundido pelo sistema ideológico do Estado Novo, sobretudo a partir do Plano dos Centenários. Esta foi uma época de grande valorização das culturas regionais a nível nacional, com figuras importantes da cultura local a tomarem a liderança. Tal foi também o caso das instituições que dirigiam os destinos regionais, como a Casa do Douro e o Instituto do Vinho do Porto, e da própria elite intelectual, com figuras como o escritor João de Araújo Correia a defender a sua criação.

Com este nome simples de Museu do Douro devia existir na Régua um estabelecimento de pura função cultural, uma casa onde se guardassem, com inteligência e carinho, curiosidades, livros raros, documentos históricos relativos ao país vinhateiro. [...] À entrada do vinhedo imenso que é o Douro, será o pórtico erguido em honra de hóspedes cultos ${ }^{1}$.

Apesar das propostas desenvolvidas, e até da compra de um edifício com este propósito, apenas em finais do século XX o museu é criado, surgindo de uma iniciativa legislativa da Assembleia da República, que aprova a Lei n. ${ }^{\circ}$ 125/97, de 2 de dezembro $^{2}$. Conforme a Lei estabelecia, foi criada uma Comissão Instaladora, com o propósito de definir alguns princípios norteadores deste equipamento, que conduzissem à sua efetivação. Contudo, o seu trabalho não foi de imediato considerado, vindo-se a estabelecer uma Estrutura de Projeto, que funcionou entre 2002 e 2004.

Este grupo de trabalho, liderado pelo professor universitário especialista na história do Douro, Gaspar Martins Pereira, desenvolveu projetos de investigação associados ao património vitivinícola, com recolha e identificação de artefactos por toda a região. Paralelamente, desenvolveram-se diversas atividades de ação cultural e educativas, envolvendo a população dos diferentes concelhos. Este programa incluiu exposições e publicações, demonstrando o potencial de um museu para esta região. Disso é bem evidente a exposição programática, Jardins Suspensos, inaugurada no Armazém 43, em Peso da Régua, a 14 de dezembro de 2003. Além da importante dimensão da vinha e do vinho durienses, abordava «os abundantes valores patrimoniais ligados ao rio, como recurso natural e como via de relações, aos ambientes de montanha, ao imaginário e às tradições populares, à história mais ou menos longínqua, ou ainda a outras culturas, como a oliveira ou a amendoeira ${ }^{3}$.

\footnotetext{
${ }^{1}$ CORREIA, 1936.

2 PORTUGAL. Assembleia da República, 1997.

${ }^{3}$ PEREIRA, SOEIRO, coord., 2003: 6.
} 
Ainda como resultado do trabalho desenvolvido por esta equipa foi elaborado o programa museológico para o Museu do Douro, documento norteador para a efetiva instalação e funcionamento do Museu.

Na sequência deste projeto foi adquirido pelo Ministério da Cultura o edifício para instalar o Museu. O imóvel escolhido foi a «Casa da Companhia», antiga sede da Companhia Geral da Agricultura das Vinhas do Alto Douro em Peso da Régua, companhia majestática instituída pelo Marquês de Pombal e que teve um papel fundamental na construção da realidade vitícola do Douro. O edifício foi reabilitado tendo em conta a nova função, inaugurando ao público a 20 de dezembro de 2008.

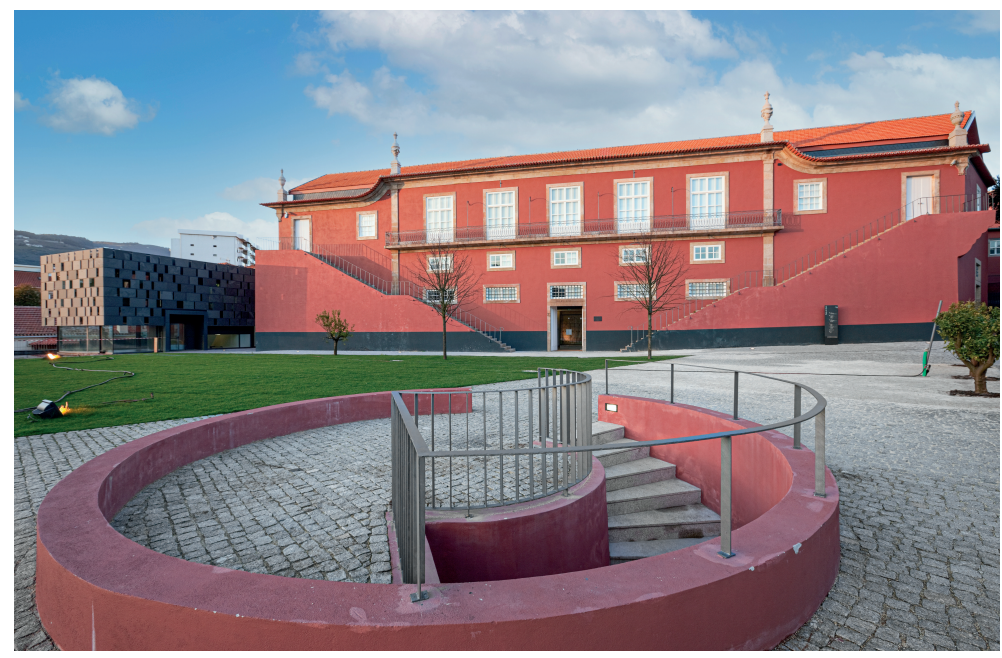

Fig. 1.

Museu do Douro «Casa da Companhia» Fonte: @MD/Luís Ferreira Alves

Ao ser criado por via legislativa, o Museu viu a sua implementação condicionada em virtude de dois pressupostos enunciados na $L e i$, e que definem a natureza deste projeto e a sua ação. Por um lado, o artigo $2 .^{\circ}$ estabelece um modelo museológico de âmbito regional, com sede em Peso da Régua e uma estrutura polinucleada distribuída pelos vinte e um concelhos da Região Demarcada do Douro (RDD) definição próxima do conceito de museu de território - , ficando a tutela a cargo da região administrativa resultante do processo de regionalização do país (artigo $4^{\circ} .^{\circ}$ ). Por outro, fixa-se o âmbito temático do Museu (artigo 3..$^{\circ}$ ), que abarca a RDD «em toda a sua diversidade cultural e natural» ${ }^{5}$. A amplitude desta temática condiciona fortemente toda a atividade do Museu, tendo em conta quer a dimensão territorial, quer a dimensão histórica desta Região. Trata-se da primeira região vitícola demarcada e regulamentada do mundo, atualmente com uma extensão de aproximadamente

\footnotetext{
${ }^{4}$ PEREIRA, 2004.

${ }^{5}$ PORTUGAL. Assembleia da República, 1997.
} 
250000 ha distribuídos ao longo do vale do Douro, entre as freguesias de Barqueiros (Mesão Frio) e Barca de Alva (Figueira de Castelo Rodrigo).

No que diz respeito à tutela, não se tendo implementado o modelo de regiões administrativas, foi aprovado um modelo de gestão fundacional, que deu origem à

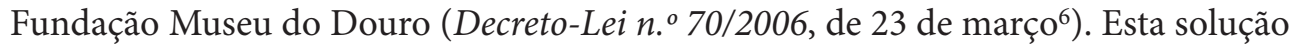
contornou a questão da regionalização administrativa do país através de um modelo de financiamento assente não na região administrativa, mas nos fundadores, onde se incluem o Ministério da Cultura, as autarquias da região e entidades privadas do mundo empresarial do vinho e de outras instituições com interesse regional. Com as alterações da lei das fundações, em 2015, a Fundação passou a fundação pública ${ }^{7}$. Esta foi uma alteração estatutária de regime de gestão, não mudando a estrutura do Museu nem a sua política museológica.

Como já se referiu, definia-se que a sede do Museu ficasse na cidade de Peso da Régua, devendo depois a sua ação estender-se a todo o território de forma polinucleada. $\mathrm{O}$ conceito museológico proposto para este projeto afasta-se da ideia tradicional de museu centrado num edifício, nas suas coleções e num público-alvo. Partilhando as ideias da nova museologia, procura antes desenvolver a sua ação dentro da comunidade da Região Demarcada do Douro, inserindo no seu âmbito de estudo e investigação além das próprias coleções, guardadas no Museu, os valores do património material e imaterial regional com valor de referência para a mesma comunidade.

Esta ideia de museu de território definida pelo decreto de criação, se interpretada de forma exata, levaria a que se criassem e implantassem vinte núcleos além da sede, um por cada concelho. Obviamente, uma solução deste tipo não seria sustentável. Como se verificou em outros países com experiências de museus polinucleados, o crescimento excessivo dos núcleos pode levar ao colapso da estrutura, obrigando a uma reestruturação que se aproxima muito do modelo tradicional de museu. Como se verá, optou-se por diferentes formas de conciliar o que está escrito na Lei com a realidade.

\section{O MUSEU - PONTO DE DESCOBERTA DE UMA REGIÃO}

Sendo Peso da Régua um dos pontos nevrálgicos na circulação pela Região, o Museu enquadrou a sua missão de dar a conhecer a Região Demarcada do Douro, de divulgar o seu património. Assim, a exposição permanente Douro: matéria e espírito tem por base essa mesma filosofia: permitir a quem aqui chega ter pistas para explorar a região. Mesmo para os seus habitantes, esta é uma forma de valorizar o seu património, o seu trabalho e a sua história através de importantes elementos identitários.

\footnotetext{
${ }^{6}$ PORTUGAL. Ministério da Cultura, 2006.

${ }^{7}$ PORTUGAL. Presidência do Conselho de Ministros, 2015.
} 


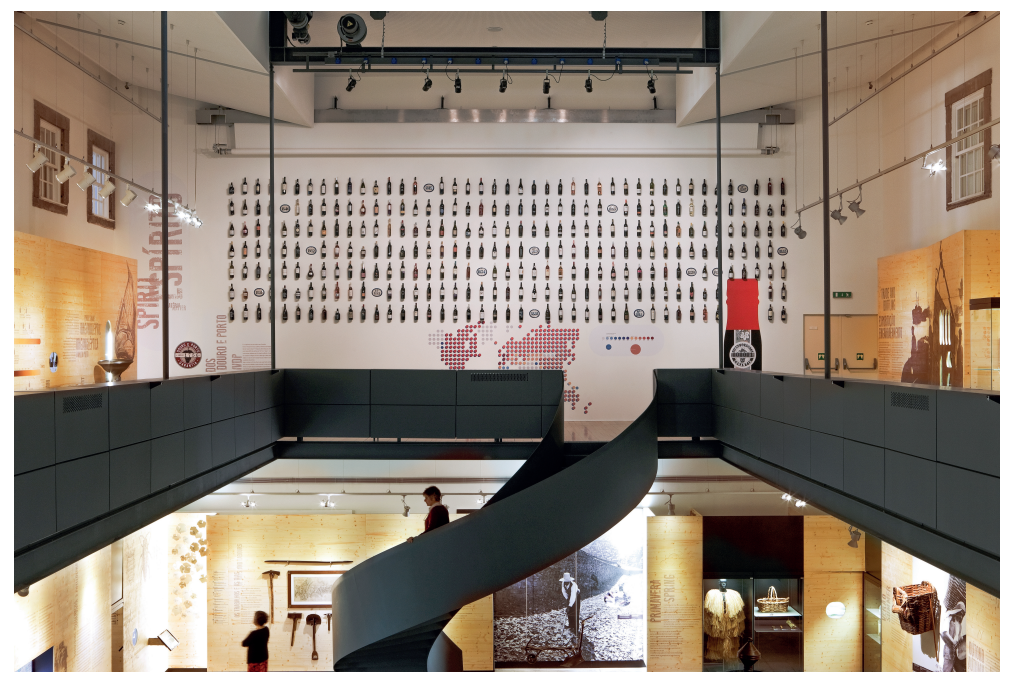

Fig. 2.

Exposição permanente Fonte: CMD/Luís

Ferreira Alves

Dividida em dois pisos, começa por apresentar a geomorfologia deste território, elemento basilar para se compreender a construção do Douro como território do vinho, cujo ato fundador foi a sua demarcação no século XVIII. Esta construção foi igualmente uma construção temporal, desde a pré-história passando pelas épocas romana e medieval, mantendo-se até aos nossos dias. Essa síntese histórica mostra igualmente os elementos da cultura mediterrânica que surgem a par do vinho. A exposição desenvolve depois outros aspectos definidores do território, como os meios de transporte, no rio, na via-férrea, ou a paisagem, classificada como Património Mundial. Antes de se passar ao segundo piso, que se desenvolve em torno do vinho - comércio, consumo - , apresenta-se uma síntese do seu fabrico desde a videira ao lagar.

Dentro do circuito de visita, o visitante pode ainda percorrer uma parte da ala técnica, conhecendo um outro lado do Museu. Esta abertura ao público dos gabinetes de conservação e restauro (sala de expurgo, quarentena, oficina, laboratório de conservação e restauro) pretende mostrar aquilo que, por norma, os visitantes não veem, mas que faz parte da vida de um museu. Nesse seguimento podem ainda ver uma pequena secção do arquivo, uma vez que a coleção arquivística é uma importante parte do espólio desta instituição, conforme, aliás, definido na lei de criação.

O museu dispõe ainda de uma Sala de Exposições Temporárias e uma Galeria onde apresenta uma programação regular dedicada ao Douro em diferentes formas artísticas - fotografia, pintura, escultura, gravura, vídeo, etc. O critério subjacente à programação é a temática ou as origens durienses do autor. Procura igualmente apresentar anualmente uma mostra que tenha interesse cultural relevante para a população local, ainda que não sendo de temática duriense. Esta é uma forma de oferecer à comunidade residente outras propostas a que, de outro modo, não teria acesso. 
São ainda espaços relevantes no Museu o wine-bar, instalado na sala de provas da Companhia, datada da primeira metade do século XIX, e o restaurante A Companhia. Além da atratividade que têm para os visitantes, enquanto espaços preservados do edifício original, constituem, a par da Loja do Museu, uma importante fonte de receita além da bilheteira. Esta estratégia é fundamental para a sustentabilidade financeira do projeto, que depende do financiamento dos seus fundadores.

O Museu dispõe também, em parceria com a Câmara Municipal de Peso da Régua e do Instituto dos Vinhos do Douro e do Porto, de uma pequena sala de espetáculos, conhecido por Teatrinho. Trata-se de um teatro do início do século XX, cuja reabilitação permitiu devolver à cidade um espaço para diferentes eventos.

\section{POLINUCLEADO: COMO DAR UM MUSEU AO TERRITÓRIO?...}

Procurando uma alternativa ao modelo polinucleado definido pela lei, mas não esquecendo a sua vocação territorial, o Museu tem atuado em distintas vertentes marcando a sua presença no seu espaço de ação. É desta forma que procura chegar aos diferentes públicos que serve, seja a população da Região Demarcada do Douro, seja o cada vez mais alargado fluxo de visitantes de outras regiões e países.

A abordagem mais direta e convencional passa pela atividade delineada anualmente, destacando-se a itinerância de exposições e o programa do Serviço Educativo. Este abrange a comunidade de crianças, adolescentes, jovens e idosos da Região nas suas atividades «de educação, de conhecimento e de entretenimento», envolvendo várias vertentes de ação, nomeadamente os projetos plurianuais e anuais com escolas, as oficinas sazonais, os percursos pedestres e as visitas guiadas às exposições do programa do $\mathrm{Museu}^{8}$. No caso das exposições itinerantes, o MD desloca-se pela região de forma rotativa, fazendo circular diferentes exposições pelos concelhos, o que se traduz numa média de cerca de vinte apresentações por ano. As equipas do MD são responsáveis pela expografia em cada local, adaptando as suas exposições a distintos equipamentos culturais; trabalham também com os técnicos de cada autarquia de modo que estes possam fazer as visitas guiadas autonomamente, mediando a comunicação com os seus próprios públicos. A rotatividade das exposições realizadas na sede permite que possam ser vistas nos diferentes concelhos, e mesmo fora da região, ganhando novas leituras com a adaptação a outros espaços expositivos. Deste modo, é possível rentabilizar o investimento de cada exposição, permitindo que um maior número de habitantes durienses tenha acesso a estes conteúdos.

\footnotetext{
${ }^{8}$ FAUVRELLE, GUIMARÃES, 2020.
} 


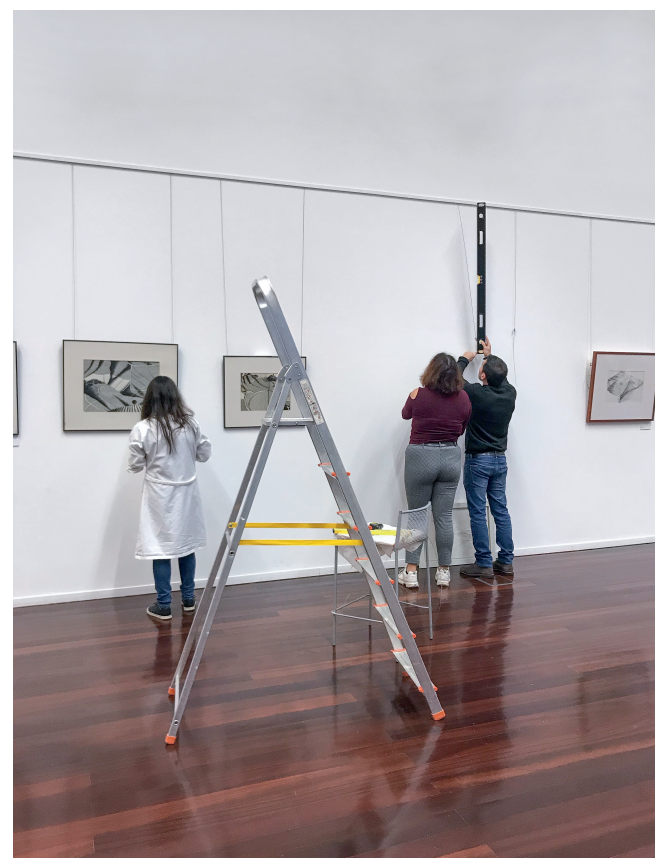

Fig. 3.

Montagem de exposição temporária Fonte: @MD/Maria João Centenário

Outra área de atuação é a investigação, que abrange não apenas as coleções à guarda do Museu, mas igualmente o património duriense. Este trabalho tem-se desenvolvido sobretudo com a realização de inventários de património de diferentes tipologias, público e privado, acompanhado pela recolha de peças para a coleção do Museu e para as exposições temporárias. Esta recolha pressupõe uma análise cuidada dos artefactos e dos saberes-fazer a eles associados, procurando-se deste modo preservar também a memória associada aos objetos e de quem os utilizou. Um dos pressupostos no tratamento do património cultural é que não se pode separar materialidade e imaterialidade. Na sua forma tangível são os artefactos que nos ajudam a recuperar o passado no presente, mas à faceta material desse passado junta-se um significado imaterial, simbólico, que contextualiza um património intangível revelado através de práticas, saberes e outras manifestações que se perpetuam. Pensar o património como relacional e processual evita esta separação, tratando os diferentes artefactos na sua globalidade.

A par destas investigações temáticas, vocacionadas para inventariar o património duriense, também se desenvolvem pesquisas que procuram refletir sobre problemáticas da museologia e deste território. Neste contexto, vários membros da equipa do Museu centraram as investigações de doutoramento em áreas temáticas associadas ao trabalho desenvolvido, nomeadamente a educação e a museologia. Um dos trabalhos, distinguido com o prémio APOM de investigação na área da museologia em 2018, analisa a paisagem Alto Douro Vinhateiro «musealizada» através da classificação 
como Património Mundial, focando-se nas questões que emergem do modelo de gestão implementado 9 . Partindo dos conceitos de paisagem e património, questiona como os mesmos são representados por quem gere e pelas comunidades que fazem a paisagem, procurando uma nova abordagem concetual que permita melhorar a eficácia da gestão deste território-museu.

Tornar o território museu é talvez a forma mais presencial e mais atuante de concretizar o conceito de museu do território. Nessa lógica é possível chamar as comunidades a participar no projeto através da identificação dos recursos a musealizar, da garantia de manutenção da sinalização colocada, enfim, do apoio que devem prestar aos visitantes que atravessam a região. Ao mesmo tempo, será da sua responsabilidade a criação de projetos, em parceria ou autonomamente, que envolvam a realização de eventos, a manutenção, venda e promoção dos produtos da terra, a conservação/preservação do património material e imaterial, entre outros, numa lógica de verdadeiro desenvolvimento comunitário.

A marcação da presença no território vem sendo feita através da sinalização e interpretação de diferentes patrimónios. Um trecho de paisagem, uma quinta, uma aldeia, um prato típico, um saber-fazer, uma memória, tudo isto constitui matéria passível de ser interpretada e apresentada aos visitantes. Ao percorrerem a Região, em parte classificada como Património da Humanidade pela UNESCO, desde 2001, poderão conhecê-la e compreendê-la melhor, complementando desta forma a visita ao espaço museológico tradicional que o Museu oferece.

Um dos projetos desenvolvidos pelo Museu do Douro é o dos Miradouros da Paisagem. O programa, implementado em 2012, incluiu a colocação de sete mesas interpretativas em pontos de passagem e observação da paisagem do Douro. Estes suportes

Fig. 4.

Mesa interpretativa em

S. Cristóvão, Sabrosa Fonte: @MD/Marco Aurélio Peixoto

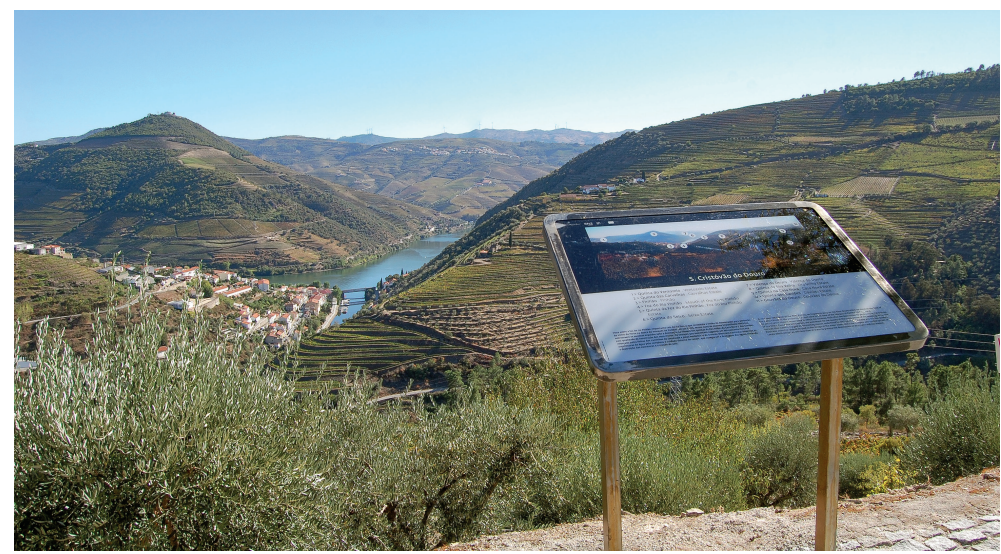

${ }^{9}$ FAUVRELLE, 2018. 
reproduzem a vista e sinalizam os principais elementos visíveis, com informação mais desenvolvida num desdobrável. Permitem uma visita autónoma e têm cumprido a sua função informativa. Será desejável continuar este processo com mais material de apoio, sobretudo disponível digitalmente, algo que está a ser pensado e trabalhado.

Numa outra vertente, mais prática, o MD tem trazido para dentro de portas o património da região com vista à sua salvaguarda através do projeto Identificar para Conservar, implementado desde 2016 para fomentar as boas práticas de preservação dos bens culturais móveis ${ }^{10}$. Focando-se nos artefactos com maior interesse patrimonial para a Região Demarcada do Douro, o objetivo deste projeto é identificar e selecionar, juntamente com os municípios, um conjunto de bens cuja conservação é prioritária. A partir desta escolha os objetos são tratados no Museu, sendo o pro-

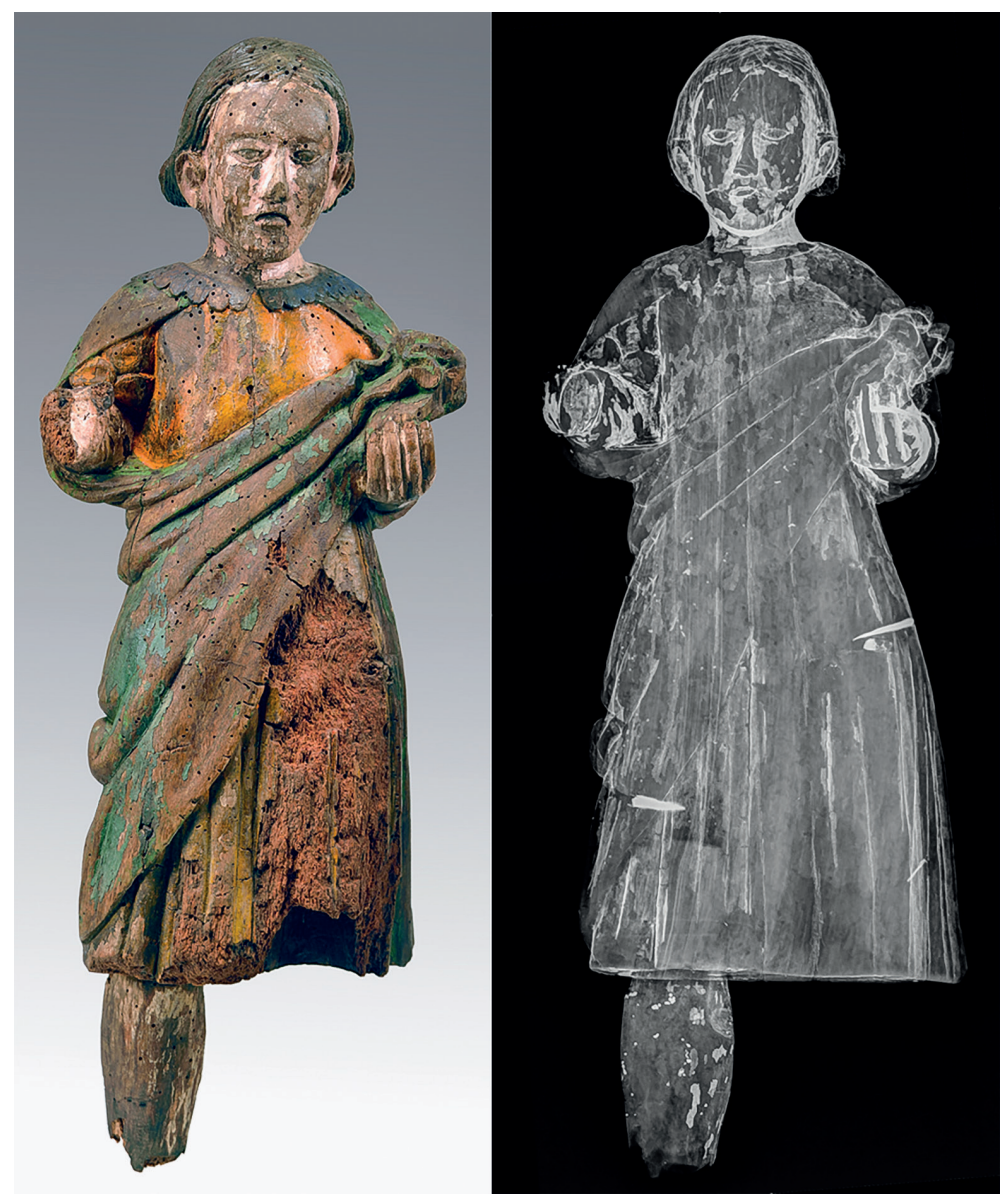

Fig. 5.

Documentação fotográfica de peça IpC. Município de São João da Pesqueira Fonte: $\odot \mathrm{MD} / J$ osé Pessoa

\footnotetext{
${ }^{10}$ A propósito deste projeto veja-se MOTA, 2019.
} 
cesso cuidadosamente documentado. Este registo acompanha depois as obras para que em cada comunidade seja visível o trabalho realizado e as implicações que tem o cuidado dos seus bens.

A metodologia de conservação seguida para cada objeto inclui: o envolvimento da tutela e da comunidade a que cada bem pertence; o estudo histórico-artístico; o levantamento fotográfico documental; o levantamento analítico; e a intervenção curativa, executada com base no princípio da sustentabilidade - esta metodologia privilegia o emprego de materiais de origem natural, ecológicos, com custos e operacionalidade viáveis.

As intervenções são acompanhadas por ações de divulgação/sensibilização e formação. Estas pretendem fazer chegar às pessoas e profissionais que lidam com bens patrimoniais a informação básica no âmbito dos cuidados preventivos. Desta forma trabalham-se conceitos e práticas que permitem prolongar a existência dos bens sem os elevados custos de uma intervenção de restauro.

No âmbito da ação cultural e artística, o MD apoiou o desenvolvimento do projeto musical Sons do Douro, em que se cruza música popular e percussão contemporânea. Evocando o imaginário duriense, parte dos sons em pipas de vinho para resgatar as memórias dos cestos vindimos, dos sons de pés a escorregar nos xistos dos socalcos, dos chocalhos das juntas de bois que ajudavam da terra os homens a puxar à sirga os barcos rabelos ou do som cantado das tesouras de poda (cf. sítio Museu do Douro ${ }^{11}$ ).

A par desta abordagem, decorrente da programação plurianual, e das itinerâncias como forma de descentralização da programação, o Museu optou, numa primeira

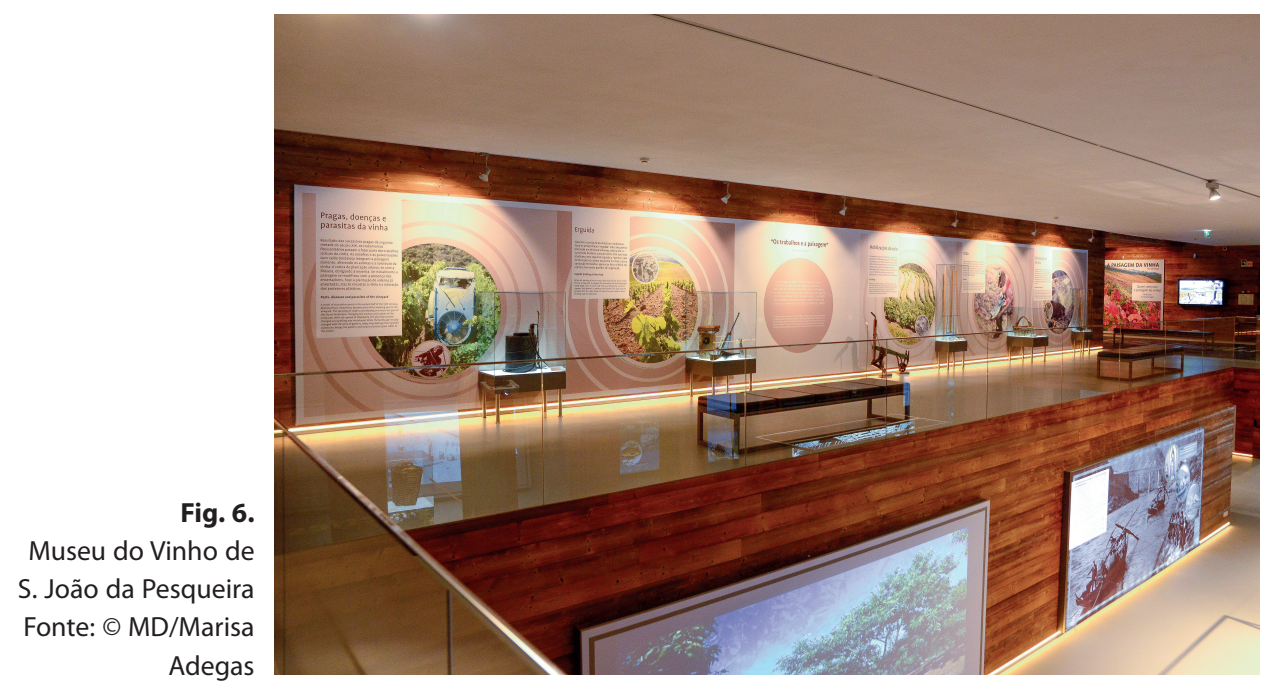

\footnotetext{
${ }^{11}$ www. museudodouro.pt.
} 
fase, por apoiar a criação de núcleos museológicos em diferentes concelhos da RDD, explorando temas fortes da Região. Elaboraram-se vários estudos nesse sentido, nomeadamente sobre o sumagre, a amêndoa, a cereja ou o pão e vinho de Favaios. Das propostas realizadas concretizaram-se no núcleo de Tabuaço, o Museu do Imaginário Duriense - MIDU, associado ao património imaterial, o Núcleo Museológico de Favaios - Pão e Vinho, no concelho de Alijó, o Museu do Vinho, no município de S. João da Pesqueira, e o Museu da Seda e do Território, em Freixo de Espada à Cinta.

O papel do Museu nestes projetos foi apoiar os executivos camarários no acesso a programas de financiamento, projeto de arquitetura e no delineamento do programa museológico, onde se incluem a preparação da exposição permanente, dos documentos normativos, a seleção e recolha de objetos para a criação da coleção e seu inventário, as intervenções de conservação preventiva e o planeando de ações de acompanhamento educativo. A direção de cada núcleo está a cargo da própria autarquia, cooperando o Museu a nível técnico sempre que solicitado.

Este modelo, que exige forte investimento financeiro, colocou em causa a viabilidade de uma estrutura polinuclear, ainda mais numa região demograficamente envelhecida e em progressivo despovoamento. Para que haja ligação há comunidade é preciso que ela lá esteja, que haja massa crítica que impulsione as atividades e o desenvolvimento do projeto. Como forma alternativa de implantar o polinuclear optou-se pela criação de uma rede de acesso informal, agregando diferentes equipamentos museológicos e com vertente museológica. Este modelo, numa lógica de partilha, permite reunir a diferente oferta através de rede de cooperação.

A Rede de Museus do Douro - MuD foi apresentada publicamente em 2007. A sua base assenta na criação de «condições de suporte entre as diferentes estruturas culturais a operar no Douro, sejam elas museus, núcleos museológicos ou quintas com coleções visitáveis, em cujas vitrinas se exibem testemunhos do património local, de tutela nacional, municipal ou privada» tendo como ponto unificador «a vocação para a conservação de testemunhos relevantes para o conhecimento da RDD com valor histórico, etnológico, científico, cultural, artístico, paisagístico, natural, etc.» ${ }^{12}$.

A ideia deste projeto é associar a atuação de cada membro de modo a rentabilizar o mais possível os recursos existentes, numa plataforma horizontal de cooperação, em que cada um deles contribui de acordo com a sua disponibilidade. Deste modo, é possível criar uma relação de partilha e troca entre as instituições, permitindo beneficiar as estruturas mais frágeis, criando progressivamente uma imagem cultural da região. Não se pretende com isto uniformizar as instituições, pelo contrário, ambiciona-se manter a diversidade e a riqueza de experiências museológicas,

\footnotetext{
${ }^{12}$ FAUVRELLE, MARQUES, 2007.
} 
respeitando a individualidade de cada instituição e promovendo a qualificação do tecido museológico regional.

Cada vez mais no meio museológico se opta por trabalhar deste modo, em que recursos humanos e financeiros podem ser rentabilizados de forma eficaz e sustentável. Esta é pois uma forma de criar um museu para o Douro a partir dos diferentes museus e estruturas museológicas no Douro.

Além de um sítio web com informação sobre cada membro e a divulgação das atividades através das redes sociais, a MuD tem atuado através da realização de reuniões regulares que permitem aos membros trocar experiências e conhecimento da realidade de cada espaço aderente. Essas reuniões revestem-se também de um carácter formativo, com a realização de palestras ou ações de formação que procuram corresponder a necessidades na área da museologia, como conservação, inventário, etc. O mais recente projeto conjunto é o lançamento de um passaporte da MuD que, dando a conhecer os diferentes espaços, funciona como um passaporte de descontos, incentivando os visitantes a percorrer a Região.

O trabalho do Museu tem ainda outras dinâmicas que são, elas mesmas, formas de ação cultural, como a apresentação das diferentes coleções ao público, presencial e virtualmente, através de exposições, catálogos e inventários em linha. A disponibilização de acervos constitui igualmente um modo de relacionamento com o território, tanto mais que quase todo o espólio resulta de doações de habitantes durienses ou com relações familiares na região. Note-se que além de peças, uma importante parte do acervo do Museu é constituída por arquivos. Embora tenham grande relevo os arquivos institucionais, como o da Companhia da Agricultura das Vinhas do Alto

Fig. 7.

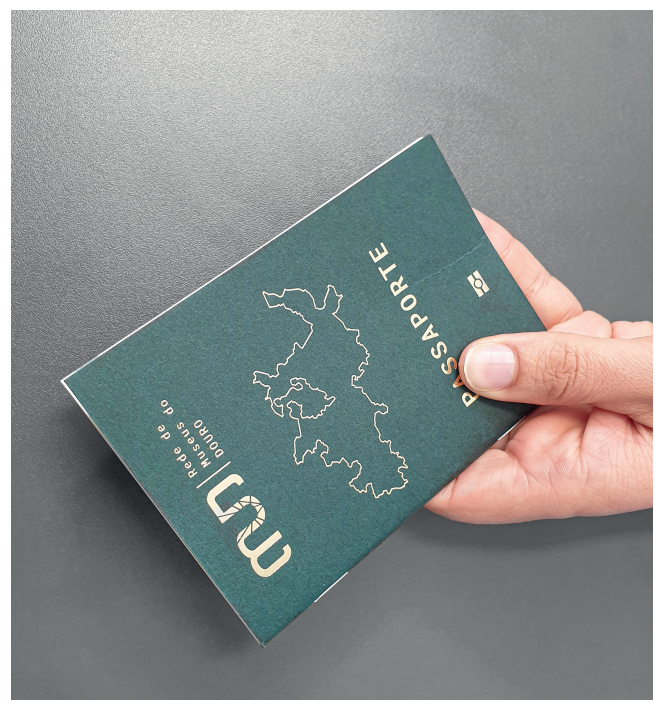


Douro e o do IVP, o MD tem recebido importantes doações e depósitos de espólios arquivísticos que paulatinamente são disponibilizados para pesquisa.

A próxima aposta a desenvolver pelo MD é a digitalização das coleções de modo a que estejam acessíveis a partir de qualquer parte do mundo. Aqui, salienta-se a parceria com a Google Arts Institute, onde se prevê criar além da visita virtual à exposição permanente e das exposições virtuais, a possibilidade de itinerários pela região, onde se incluem quintas e monumentos.

Desde a sua criação legislativa, em 1996, o projeto de um museu para a região do Douro percorreu um longo caminho para se materializar e dar corpo à missão de preservar e divulgar o património da RDD. Ainda que o texto da lei propusesse uma estrutura polinucleada, a procura de um paradigma museológico que se adequasse à realidade financeira e técnica da região levou a outros caminhos. Um museu de território não é o mesmo que um museu polinucleado. Pode estar e trabalhar com e para o território sem necessariamente criar uma pesada estrutura polinucleada, através da programação e do desenvolvimento de investigação inclusiva do território.

\section{LEGISLAÇÃO}

PORTUGAL. Assembleia da República (1997). Lei n. ${ }^{\circ}$ 125/97. «Diário da República Série I-A». 278 (1997-12-02) 6433-6434.

PORTUGAL. Ministério da Cultura (2006). Decreto-Lei n. ${ }^{\circ}$ 70/2006. «Diário da República Série I-A». 59 (2006-03-23) 2171-2177.

PORTUGAL. Presidência do Conselho de Ministros (2015). Decreto-Lei n. ${ }^{\circ}$ 16/2015. «Diário da República Série I». 22 (2015-02-02) 634-641.

\section{BIBLIOGRAFIA}

CORREIA, João de Araújo (1936). O Museu do Douro. «Jornal da Régua». (19 jan. 1936).

FAUVRELLE, Natália (2010). Museu do Douro: um museu para um território. In Atas do Encontro «Museus e Sociedade». Caminha: Câmara Municipal de Caminha.

FAUVRELLE, Natália (2018). Fazer a paisagem no Alto Douro Vinhateiro: desafios de um território-museu. Porto: Faculdade de Letras da Universidade do Porto. Tese de doutoramento.

FAUVRELLE, Natália; GUIMARÃES, Samuel (2020). Museu do Douro - programação como mediação cultural. In PORTUGAL. Ministério da Cultura. Direção Regional de Cultura do Norte. Mediação Cultural: objetos, modelos e públicos. Porto: DRCN, pp. 81-95. (Património a Norte; 5).

FAUVRELLE, Natália; MARQUES, Susana (2007). MUD - uma rede de museus para o Douro. In Atas do $1^{\circ}$ Encontro de Museus do Douro. Peso da Régua: Museu do Douro. Disponível em <http:// www.museudodouro.pt/tpls/mu/files/encontros/pdf/natalia.pdf $>$.

MOTA, Carlos (2019). Identificar para Conservar - um projeto de conservação no território. In PEREIRA, Gaspar M.; AMORIM, Maria Norberta; LAGE, Maria Otília Pereira, orgs. Douro e Pico, paisagens culturais património mundial. Porto: CITCEM, pp. 53-68.

PEREIRA, Gaspar Martins (2004). Estrutura de Projeto do Museu do Douro: relatório. Régua: Museu do Douro. Policopiado.

PEREIRA, Gaspar Martins; SOEIRO, Teresa, coord. (2003). Jardins Suspensos: Roteiro. Régua: Museu do Douro. 



\section{PAISAGEM DA CULTURA DA \\ VINHA DA ILHA DO PICO (QUINZE ANOS PATRIMÓNIO MUNDIAL DA UNESCO) \\ III WORKSHOP DOURO E PICO 2019}

COORD.

MARIA OTÍLIA PEREIRA LAGE

MANUEL PAULINO DA COSTA 